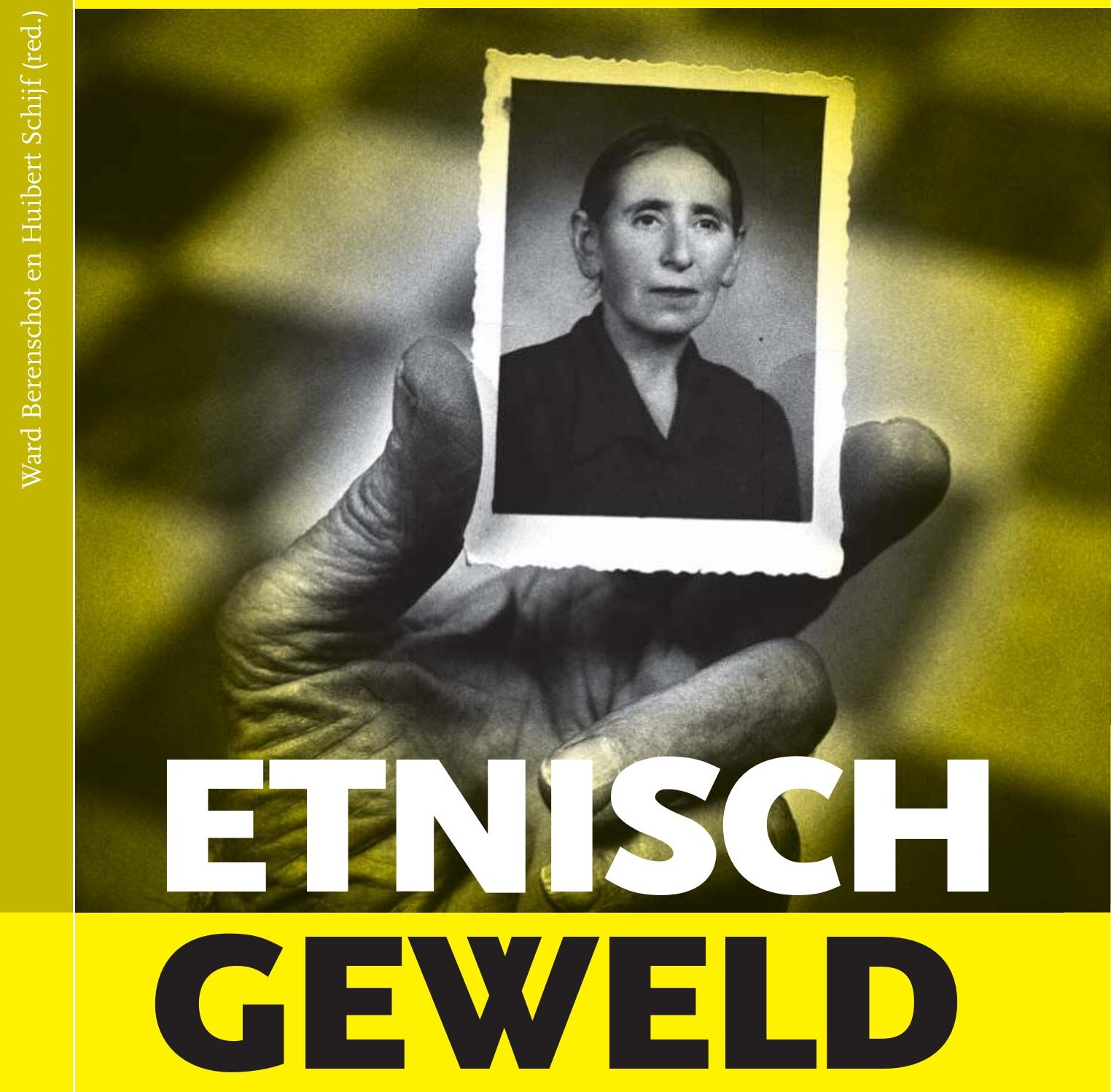

Groepsconflict in de schaduw van de staat 
Etnisch geweld 



\section{Etnisch geweld}

Groepsconflict in de schaduw van de staat

Onder redactie van

Ward Berenschot

Huibert Schijf 
Etnisch geweld: groepsconflict in de schaduw van de staat is de boekaflevering bij jaargang 84 (2009) van het sociaal-wetenschappelijk tijdschrift Mens \& Maatschappij.

Omslagafbeelding: Kathryn Cook / Agence Vu / Hollandse Hoogte

Omslagontwerp: Jos Hendrix, Groningen

Vormgeving binnenwerk: PRografici, Goes

$\begin{array}{llll}\text { ISBN } & 978908964 & 1731 \\ \text { e- ISBN } & 978904851 & 1358 \\ \text { NUR } & 741\end{array}$

(C) Ward Berenschot en Huibert Schijf / Amsterdam University Press, Amsterdam 2009

Alle rechten voorbehouden. Niets uit deze uitgave mag worden verveelvoudigd, opgeslagen in een geautomatiseerd gegevensbestand, of openbaar gemaakt, in enige vorm of op enige wijze, hetzij elektronisch, mechanisch, door fotokopieën, opnamen of enige andere manier, zonder voorafgaande schriftelijke toestemming van de uitgever.

Voor zover het maken van kopieën uit deze uitgave is toegestaan op grond van artikel 16B

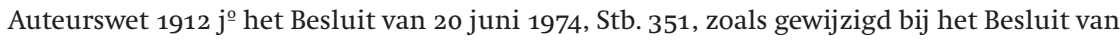
23 augustus 1985, Stb. 471 en artikel 17 Auteurswet 1912, dient men de daarvoor wettelijk verschuldigde vergoedingen te voldoen aan de Stichting Reprorecht (Postbus 3051, 2130 KB Hoofddorp). Voor het overnemen van gedeelte(n) uit deze uitgave in bloemlezingen, readers en andere compilatiewerken (artikel 16 Auteurswet 1912) dient men zich tot de uitgever te wenden. 


\section{Inhoudsopgave}

$\begin{array}{ll}\text { Voorwoord } & 7\end{array}$

Ward Berenschot en Huibert Schijf

Etnisch geweld in de schaduw van de staat $\quad 9$

Uğur Ümit Üngör

Massamoord en lokale elites in Turkije, 1913-1918

Koen Vlassenroot en Karen Büscher

Identiteit, patronage en geweld in Oost-Congo

Jacob R. Boersema

Genocide in een Rwandees dorp

Ward Berenschot

Het ontstaan van een pogrom in Gujarat

Gerry van Klinken

Etnisch geweld op Ambon

Ton Zwaan

Een theoretisch perspectief op etnisch geweld 151

Personalia 



\section{Voorwoord}

Dit boek gaat over geweld tussen etnische groepen op stedelijk en regionaal niveau. Het centrale thema is dat etnisch geweld zelden alleen maar een spontane uitbarsting is van spanningen tussen bevolkingsgroepen die hun onderscheid baseren op religie, taal, etnische of nationale verschillen. Dikwijls is het ook een georkestreerd spektakel dat verschillende politieke en economische doelen dient. De beschreven regio's zijn over de wereld verspreid: Oost-Congo, Rwanda, Gujarat in India, Ambon in Indonesië en Turkije. Het zou niet moeilijk zijn geweest deze vijf met vele andere etnisch explosieve regio's aan te vullen. Het beschreven etnisch geweld heeft de afgelopen decennia plaatsgevonden, behalve de massamoord op Armeense burgers in Turkije. Die gebeurde aan het begin van de twintigste eeuw.

Nederland behoort niet tot de gekozen regio's, want daarvoor is de Nederlandse samenleving veel te vreedzaam. Over de vraag of er in Nederland wel politiek geweld bestaat valt te discussiëren, in het laatste decennium hebben immers enkele politieke moorden plaatsgevonden. Maar een voorbeeld van geweld tussen etnische groepen waarbij aan beide kanten in enkele jaren tijd duizenden doden vallen is in de Nederlandse geschiedenis niet aan te wijzen.

Alle auteurs hebben veldwerk verricht in de regio's die ze beschrijven en ze gebruikten onderzoeksmethoden die bij antropologen en historici vanzelfsprekend zijn, zoals interviews, observaties en archiefonderzoek. Soms zijn bronnen geraadpleegd die moeilijk toegankelijk zijn, bijvoorbeeld Turkse archieven. Het gebruik van deze methoden wil niet zeggen dat de theoretische benadering van de auteurs ook typisch antropologisch zou zijn. Die is eerder politicologisch of sociologisch te noemen met aandacht voor de rol van de staat en het gebruik door politici van netwerken op diverse niveaus. Verscheidene auteurs zijn politicoloog, de 
academische achtergrond van de overigen is divers, zoals de lijst met personalia laat zien.

Samen met een inleiding over etnisch geweld en een slotbeschouwing over een geïntegreerde theoretische benadering van politiek en etnisch geweld, bieden de vijf regionale studies een vergelijkend perspectief op een type geweld dat in uiteenlopende regio's het dagelijks leven van vele mensen bepaalt.

Ward Berenschot en Huibert Schijf 


\title{
Etnisch geweld in de schaduw van de staat
}

\author{
Ward Berenschot en Huibert Schijf
}

\section{Inleiding}

De neiging van mensen om elkaar op de meest 'onmenselijke' manieren om het leven te brengen alleen vanwege - althans op het eerste gezicht - een ervaring van 'anders zijn', blijft moeilijk te bevatten. Wat bezielt mensen om een dergelijk intense haat te voelen tegenover personen die ze nog nooit ontmoet hebben, alleen omdat ze bij een 'andere' groep zouden horen? En andersom, hoe kan het dat een angst voor een dergelijke abstracte 'andere' groep mensen ertoe brengt hun buren te gaan verafschuwen, en soms zelfs de dood in te jagen? Wat bezielt mensen überhaupt om soortgenoten die in zoveel aspecten hetzelfde zijn, te bezien als 'anderen'?

In de laatste twee decennia hebben deze vragen zich steeds meer opgedrongen. Want het einde van de Koude Oorlog ging gepaard met een grote toename van gewelddadigheden die om etnische tegenstellingen leken te draaien. Terwijl het uiteenvallen van Joegoslavië leidde tot grootschalige etnische zuiveringen, escaleerde vijandelijkheden tussen Armeniërs en Azeri tot een complete burgeroorlog. In 1994 was de genocide tegen de Tutsi's in Rwanda het dieptepunt van een hele reeks etnische gewelddadigheden in verscheidene Afrikaanse landen, terwijl in zowel India als Indonesië duizenden doden vielen bij bloedige rellen tussen religieuze gemeenschappen. Al nam de schaal van het geweld de laatste jaren iets af (Harbom en Wallensteen, 2007), etniciteit en politiek bleven een gevaarlijk mengsel, zoals de recente uitbarstingen tussen Luo's en Kikuyu's in Kenia na de verkiezingen en tussen christenen en moslims in Nigeria illustreren. Onderzoekers die databases van gewelddadigheden bijhielden, konden de relatieve toename van etnisch geweld met cijfers staven: van alle gewelddadige conflicten in de jaren vijftig en zestig kon twintig tot dertig procent toegeschreven worden aan etni- 
sche tegenstellingen. Interstatelijke oorlogen, onafhankelijkheidsstrijd of ideologisch gemotiveerde burgeroorlogen waren de oorzaak voor de overige doden. In de jaren negentig en de eerste jaren van de eenentwintigste eeuw kreeg tussen de vijftig en zeventig procent van alle geweldsuitbarstingen het label 'etnisch geweld'. ${ }^{1}$

Sommige schrijvers betoogden dat het einde van de Koude Oorlog 'het deksel' van allerlei broeiende spanningen had afgehaald (Kaplan, 1994). Anderen meenden dat er een nieuw soort burgeroorlog was ontstaan, die minder leek te gaan over ideologische tegenstellingen, maar alles te maken had met een mobilisering van geweld rond etnische identiteiten waarvan burgers het slachtoffer werden (Kaldor, 2004). In diezelfde geest concludeerden steeds meer onderzoekers dat het bestaan van etnische tegenstellingen op zich niet als oorzaak van deze gewelddadigheden kon worden aangemerkt. Niet alleen vanwege het feit dat in heel veel landen etnische diversiteit helemaal niet tot geweld leidt, maar vooral omdat onderzoekers steeds meer oog kregen voor de manieren waarop politieke elites etnische tegenstellingen manipuleren voor eigen gewin. Zowel grootschalig kwantitatief onderzoek (Collier en Hoeffler, 2004; Fearon en Laitin, 2003) als vergelijkingen op basis van gedetailleerde analyses van geweldsuitbarstingen (Horowitz, 2002; Valentino, 2004; Mann, 2005) leidden tot de conclusie dat de escalatie van spanningen tussen etnische groepen een strategische keuze is van politieke elites.

In die zin is 'etnisch geweld' eigenlijk een verkeerde term. Etnisch geweld is niet alleen een uitbarsting van spanningen tussen bevolkingsgroepen, etnisch geweld is ook een georganiseerd spektakel dat verschillende politieke en economische doelen dient. De menigten die zich overgeven aan het vermoorden, verminken en verkrachten van mensen die in hun eigen buurt wonen, zijn dikwijls gemobiliseerd door elites die het geweld exploiteren voor eigen gewin. Het vijandbeeld dat de strijdende bevolkingsgroepen van elkaar hebben is daarbij zelden een historisch gegeven, maar wordt aangewakkerd en gevoed door deze leiders. Eigenlijk zou het beter zijn om van 'politiek geweld' te spreken in plaats van 'etnisch geweld'.

Toch leidt een dergelijke gerichtheid op de strategieën van politieke leiders niet tot een bevredigende verklaring van etnisch geweld. Want zelfs als we aannemen dat elites inderdaad een strategische keus maken om geweld aan te moedigen, hoe kunnen we dan verklaren dat zij erin slagen om mensen aan te zetten tot geweld die helemaal niet dezelfde belangen hebben bij dit geweld? Laten deelnemers aan geweld zich echt misleiden door complot-smedende leiders? Door welke processen kunnen grote groepen mensen overgehaald worden tot massaal geweld en hoe groot is het vermogen van politieke elites om etnische tegenstellingen te creëren en ten eigen voordeel te gebruiken? Dat zijn de vragen waar dit boek zich op richt. 
Dit boek bevat twee hoofdstukken over de lokale dynamiek achter grootschalige geweldsuitbarstingen als de Armeense genocide en de genocide in Rwanda. Er is ook een bijdrage over de relatief kleinschaligere rellen tussen christenen en moslims op Ambon, Indonesië. Een andere bijdrage bespreekt de achtergronden van de burgeroorlog in Oost-Congo. Ten slotte komt het straatgeweld tussen hindoes en moslims in de deelstaat Gujarat in India aan bod. Door een aantal verschillende casussen bijeen te brengen beoogt dit boek te laten zien dat er - ondanks de vele in het oog lopende verschillen - verschillende gemeenschappelijke kenmerken bij de escalatie van etnisch geweld onderscheiden kunnen worden. Dankzij uitgebreid etnografisch en historisch onderzoek kunnen deze studies een inzicht bieden in de manier waarop de mobilisatie voor geweld feitelijk plaatsvindt en hoe de mechanismen functioneren die deze mobilisatie mogelijk maken.

Een gemeenschappelijk kenmerk in de vijf studies blijkt te liggen in de politisering van etnische tegenstellingen en in de manier waarop politieke leiders aanhang rond deze tegenstellingen weten te mobiliseren. Dat blijkt samen te hangen met de wijze waarop de toegang tot staatsinstellingen is georganiseerd. De politisering van etnische verschillen hangt vaak samen met de rol die etniciteit speelt bij het verkrijgen van toegang tot overheidsdiensten (of alternatieven daarvoor) en goederen. Bovendien blijken de netwerken die toegang tot de staat bieden ook een rol te spelen bij de daadwerkelijke geweldsescalatie. Bij diverse gevallen van etnisch geweld, hoe uiteenlopend ook, blijkt er een overlap te bestaan tussen de netwerken van actoren die betrokken zijn bij het organiseren en instigeren van geweld en de patronagenetwerken die burgers helpen toegang te verkrijgen tot de diensten die de staat te bieden heeft.

Politici, ambtenaren, dorpshoofden, clanleiders, criminelen of militieleiders ontlenen hun status en invloed mede aan hun toegang tot de schaarse goederen en diensten zoals scholing, banen, regulering van handel, medische zorg en leningen die de staat te bieden heeft. De personen in deze netwerken functioneren in de 'schaduw' van de staat: ze profiteren van hun vermogen om, door middel van uiteenlopende persoonlijke connecties en een uitruil van gunsten, de distributie van staatsgoederen en de toepassing van wetten te manipuleren. De 'schaduw van de staat' wordt hier op een bredere manier gebruikt dan de term shadow state, een concept dat Reno (200o) lanceerde om de politieke economie van een aantal Afrikaanse staten te beschrijven. De clandestiene netwerken die Reno shadow states noemt, ziet hij als alternatieve autoriteiten die hun bestaan en inkomen ontlenen aan hun capaciteit om handelsstromen te reguleren buiten de staat om.

Dankzij het inkomen dat dit oplevert, opereren deze netwerken relatief onafhankelijk van staatsmiddelen. Ons gebruik van het begrip 'scha- 
duw van de staat' is breder, omdat we het hier ook hebben over netwerken die functioneren als intermediairs tussen staat en burger en die hun bestaan ontlenen aan hun toegang tot staatsmiddelen. Deze netwerken concurreren niet met de staat; in de dagelijkse praktijk zijn zij een symbiotisch onderdeel van de staat (vergelijk Reno, 200o). Al is de context steeds verschillend, het zijn steeds weer deze politieke en soms criminele netwerken die in de 'schaduw' van de staat opereren, die een belangrijke rol spelen in het aanzetten tot en het organiseren van geweld. En het is juist het dagelijks functioneren van deze netwerken die de infrastructuur creëert die politieke elites gebruiken om mensen aan te zetten tot geweld.

Door verschillende casussen te vergelijken kunnen we een beter inzicht krijgen in de relatie tussen de karakteristieken van de 'schaduw van de staat' en het wel of niet uitbreken van etnisch geweld. Door aandacht te schenken aan de omstandigheden die het functioneren van deze 'schaduw van de staat' beïnvloeden kunnen we een beter inzicht krijgen in de omstandigheden die politieke elites in staat stellen om grootschalig geweld te organiseren. Uitgaande van deze condities zal Zwaan in zijn slotbeschouwing een aanzet geven tot een synthese van het onderzoek naar etnisch geweld. Alvorens de netwerkbenadering verder uit te werken is het van belang aan te stippen hoe de argumenten in dit boek aansluiten bij bestaande benaderingswijzen van etnisch geweld.

\section{Het verklaren van geweld}

Allereerst iets over terminologie. Zoals al blijkt uit de verscheidenheid van de casussen die in dit boek aan bod komen hanteren we een brede definitie van etnisch geweld en etniciteit. Onder etnisch geweld verstaan we geweldsdaden die (a) gepleegd worden uit naam van een etnische groep, (b) gemotiveerd worden door haat of afkeer van een andere etnische groep en (c) waarbij de slachtoffers uitgekozen zijn op basis van hun etnische achtergrond (vergelijk Fearon en Laitin, 2000a). De nadruk bij deze definitie ligt op de rol die etnische scheidslijnen spelen in het organiseren van en motiveren tot geweld, niet op de precieze vorm die dit geweld aanneemt: etnisch geweld is een term die zowel grootschalige genocide, burgeroorlogen als straatgeweld beschrijft, en die verwijst naar zowel het geweld gepleegd door legereenheden als door woedende mensenmenigtes.

Cruciaal in deze definitie is natuurlijk de betekenis van de term 'etnisch'. De term wordt op verwarrend veel manieren gebruikt. Waar sommigen alleen over etniciteit spreken als ze verwijzen naar verschillen in afkomst, worden ook religie, taal, regionale achtergrond, een gedeelde geschiedenis of cultuur aangemerkt als onderscheidende ken- 
merken van een 'etnische groep'. De term 'etnisch geweld' wordt ook gebruikt voor gewelddadigheden tussen zeer uiteenlopende groepen. Waar in veel Afrikaanse landen, zoals Burundi, Somalië en Kenia, verschillende stammen tegen elkaar strijden, vonden andere uitbarstingen van 'etnisch geweld' plaats tussen religieuze groepen, zoals het geweld tussen christenen en moslims in Nigeria of Indonesië, of het geweld tussen protestants en katholieken in Noord-Ierland. Veel geweld in India vindt plaats tussen verschillende kasten, terwijl geweld ook sektarisch genoemd zou kunnen worden, zoals het geweld tussen soennitische en shiitische moslims in Irak.

Sommige auteurs gebruiken de term 'etnisch geweld' dan ook alleen voor geweld tussen groepen die hun afkomst gemeen hebben, zoals clans of stammen. Het bredere begrip 'communaal geweld' hanteren zij voor al het geweld tussen groepen die op meer culturele gronden, religie, nationaliteit en taal, kunnen worden onderscheiden. Dit gebruik van verschillende concepten wordt nog verwarrender door het feit dat etniciteit niet als een vaststaand, onveranderlijk gegeven kan worden gezien. Bijvoorbeeld de nu zo tragische tegenstellingen tussen Hutu's en Tutsi's zijn geaccentueerd door de Belgische koloniale heersers die een tegenstelling tussen sociale klassen voor een etnisch onderscheid aanzagen. De perceptie van een bepaalde groep is geen vaststaand gegeven, maar een sociale constructie die versterkt of verzwakt kan worden.

Twee zaken keren steeds terug. Wat al die verschillende aspecten van 'etniciteit' gemeen hebben is dat het gaat om een toegeschreven kenmerk dat iedereen bij de geboorte meekrijgt en dat tijdens de opvoeding en maatschappelijke socialisatie met een onontkoombaar aura wordt omgeven. Het gaat om een aspect van iemands identiteit dat, althans in de perceptie van zowel de betrokkene als zijn sociale omgeving, niet gekozen is. Het is een lidmaatschap verkregen bij de geboorte. Ten tweede is het belangrijk om te benadrukken dat het om de ervaring van gemeenschappelijkheid gaat. De gemeenschappelijkheid die leden van een sociale groep ervaren is geen vaststaand, 'natuurlijk' gegeven, maar veranderlijk en afhankelijk van politieke en sociale omstandigheden.

Deze twee observaties indachtig worden de termen 'etniciteit' en 'etnische groep' in dit boek in brede zin gebruikt. Ze verwijzen naar sociale groepen waarvan het lidmaatschap als onontkoombaar wordt ervaren en die een onderscheid maken tussen zichzelf en anderen op basis van culturele verschillen, zoals een gedeelde geschiedenis, taal, religie, nationaliteit of biologische kenmerken (ras). Een pragmatische reden voor zo'n brede definitie is dat, zoals de hoofdstukken zullen illustreren, verschillen tussen zowel religieuze groepen als tussen clans en stammen op vergelijkbare manieren worden gemanipuleerd en gebruikt door de politieke elites. Daarmee is de dynamiek achter dergelijk etnisch, sekta- 
risch of communaal geweld vergelijkbaar. Er zijn ook inhoudelijke redenen om gewelduitbarstingen tussen verschillende groepen onder de noemer 'etnisch geweld' te plaatsen. De verklaringen voor etnisch geweld in de literatuur zijn namelijk zeer divers. We onderscheiden vier hoofdstromingen, namelijk primordialisme, instrumentalisme, constructivisme en een psychologisch perspectief.

Primordialisme is een stroming die tegenwoordig onder academici nog maar weinig aanhang geniet, maar die in journalistieke analyses nog regelmatig opduikt. Deze benadering ziet het bestaan van basale 'primordiale' verschillen tussen bevolkingsgroepen, bijvoorbeeld gebaseerd op ras, religie of cultuur, als oorzaak van gewelddadig conflict. Het lidmaatschap van een sociale groep voorziet mensen van een oriëntatie en zingeving in het leven en die behoefte van een groep kan zo sterk zijn dat het hun waarnemingen en gedrag beïnvloedt (Geertz, 1963). Deze 'primordiale' gehechtheid voedt de neiging om zich te associëren met mensen die dezelfde identiteit delen ('wij') en om animositeit te voelen tegen mensen die deze identiteit niet delen ('zij'). Uitgaande van deze aannames wordt etnisch geweld vaak verklaard door te verwijzen naar ancient hatreds. Het feit dat etnische groepen in het verleden al vaker gebotst zijn zou dan een verklaring zijn voor het huidige geweld. Een goed voorbeeld van een dergelijke visie is de analyse die Kaplan (1993) geeft van het geweld in voormalig Joegoslavië door te wijzen op een lange geschiedenis van eerdere gewelddadigheden.

Instrumentalisten namen het al snel op tegen deze verklaringswijze. Zij betoogden dat primordialisten geen oog hebben voor de manier waarop politieke elites omstandigheden gebruiken om hun eigen belangen na te streven. Etnisch geweld is dan niet het gevolg van het bestaan van etnische verschillen in een land, maar van de manier waarop politieke elites van deze verschillen gebruikmaken om hun eigen politieke en economische belangen te dienen. Deze wetenschappers richten zich ook op de rol die elites spelen bij het aanjagen van tegenstellingen en het organiseren van geweld. Volgens de instrumentalisten moeten de verklaringen voor etnisch geweld gezocht worden in de omstandigheden die het voor politieke elites voordelig maken om geweld te laten uitbreken. Dat geweld zou dreigen als politici een belang hebben bij het polariseren van het electoraat (Brass, 2003) en als een meerderheidspartij verkiezingen kan winnen zonder steun van een minderheid (Wilkinson, 2004).

Een variant van het debat tussen primordialisten en instrumentalisten is het recente greed versus grievance-debat over de oorzaken van burgeroorlogen. Aan de ene kant staan auteurs als Azar (1990) die betoogt dat gewelddadige conflicten het gevolg zijn van een door burgers ervaren maatschappelijke achterstelling (grievance). In zijn visie kunnen conflicten escaleren als etnische bevolkingsgroepen relatief slecht kunnen 
voorzien in hun basisbehoeftes en relatief minder toegang hebben tot de staat. Azars stelling werd ontkracht, want uit de kwantitatieve analyses van Collier en Hoeffler (2004) en Fearon en Laitin (2003) blijkt dat burgeroorlogen helemaal niet vaker voorkwamen in etnisch diverse landen met een hoge mate van sociale ongelijkheid. Een vertoog over achterstelling zou een manier van elites zijn om hun ware belangen - hun greed - te verhullen. Volgens deze auteurs vinden burgeroorlogen plaats als ze geld opleveren, hetzij vanwege omstandigheden die de kosten van oorlog voeren laag houden, bijvoorbeeld door steun uit de diaspora, de aanwezigheid van veel werkloze jongeren, een zwakke staat, of een ruig landschap waar opstandelingen zich gemakkelijk schuil kunnen houden, hetzij vanwege omstandigheden die de baten vergroten, zoals de gelegenheid om controle te verwerven over gemakkelijk verhandelbare grondstoffen als diamanten, metalen of hout. Het debat lijkt zich recentelijk naar een tussenweg te bewegen. Steeds meer auteurs betogen dat de tegenstelling tussen greed en grievance vooral goed klinkt, maar verhult dat in de praktijk opportunistische motieven en gevoelens over onrecht op complexe manieren met elkaar samenhangen. Op basis van nieuw statistisch materiaal is betoogd dat burgeroorlogen vaker voorkomen in landen waar grote 'horizontale ongelijkheden' tussen groepen bestaan (Stewart en Brown, 2007), of waar de toegang tot de staat georganiseerd is op basis van etniciteit (Wimmer et al., 2009).

Een derde belangrijke stroming in het onderzoek naar etnisch geweld is het sociaal constructivisme. In tegenstelling tot vooral het primordialisme benadrukt deze stroming dat een etnische identiteit helemaal geen vastomlijnd en onveranderlijke onderdeel van onze persoonlijkheid is. Mensen hebben verscheidene identiteiten en het relatieve belang van deze identiteiten is voortdurend aan verandering onderhevig. Zo verklaren sociaal-constructivisten etnisch conflict door te zoeken naar redenen waarom de ervaring van etnische tegenstellingen een steeds prominenter onderdeel van het dagelijks leven zijn gaan uitmaken. Een religieuze of etnische identiteit kan steeds prominenter worden, doordat koloniale heersers hun beleid gingen vormgeven rond etnische tegenstellingen (Pandey, 1992). Mondialisering en economische liberalisering creëren onzekerheden betreffende de relatieve status van sociale groepen, doordat politieke leiders met hun speeches en gebruik van symbolen een groep ‘tot leven kunnen praten' (Blom Hansen, 2001; Van der Veer, 1994; Roy, 1994). Deze stroming biedt belangrijke handvaten om te begrijpen hoe maatschappelijke veranderingen leiden tot een etnisch conflict. Toch blijft een belangrijke beperking dat etnisch conflict vaak wordt gelijkgesteld met geweld, maar het verklaren van een ervaring van etnische tegenstellingen is nog niet hetzelfde als het verklaren waarom geweld uitbreekt (Fearon en Laitin, 200ob). 
Een vierde zeer diverse stroming hanteert een psychologisch perspectief. Deze verklaringswijze gebruikt psychologische inzichten om te begrijpen waarom mensen voldoening halen uit het plegen van geweld. Zo wordt er betoogd dat geweld voortkomt uit de behoefte om de superioriteit van de eigen groep te vestigen: sociale onzekerheid, of een gevoel van minderwaardigheid, kan worden weggenomen om door middel van geweld de status van de eigen groep te bewijzen. Zowel Blok (2001) als Ignatieff (1998) heeft gebruikgemaakt van Freud om te betogen dat geweld voorkomt uit een 'narcisme van de kleine verschillen': vooral in situaties waar de verschillen tussen groepen klein zijn is er een grotere behoefte om de relatieve status te bevestigen door middel van geweld. Etnisch geweld is een narcissistic rage (Kakar, 1996). Dit is een verklaring voor de vele verkrachtingen tijdens etnisch geweld. Door ongestraft de eer van andermans vrouw te schenden kunnen mannen symbolisch elkaars inferioriteit bewijzen. In deze lijn wordt etnisch geweld wel verklaard door te wijzen op de onzekerheden die mondialisering teweeg heeft gebracht doordat kennis van andere leefwijzen is toegenomen en een toenemende economische competitie is ontstaan. Daardoor zijn zekerheden over de eigen positie in een samenleving in de relatie tot andere groepen op losse schroeven komen te staan. Etnisch geweld als een directe, fysieke aanval op het lichaam van 'de ander' en biedt de ultieme manier om maatschappelijke verhoudingen 'duidelijk' te krijgen, etnisch geweld biedt dead certainty (Appadurai, 1998).

Een andere sociaal-psychologische verklaring ziet etnisch geweld als een ontlading van opgehoopte spanningen over eigen onvolkomenheden. De aspecten van het leven die aanleiding voor schaamte en zelfhaat geven worden geprojecteerd op de andere etnische groep. Zo biedt het plegen van geweld een mogelijkheid voor catharsis, een kans om de eigen onvolkomenheden uit te drijven. Geweld is dan 'a substitute for expelling or annihilating the enemy one harbors within oneself, which may account for the over determined brutality against and guiltless obliteration of the "other" ' (Tambiah, 1996: 276; zie ook Nussbaum, 2007).

Al deze verklaringen bieden belangrijke inzichten in het fenomeen etnisch geweld en verschillende aspecten van deze benaderingen zijn terug te vinden in de verschillende hoofdstukken. Als er al iets algemeens geconcludeerd kan worden, dan is het wel dat etnisch geweld geen enkelvoudige 'hoofdverklaring' heeft en het uitbreken van etnisch geweld altijd een reeks van zeer verschillende oorzaken heeft. Door het bijeenbrengen van verschillende perspectieven kunnen we een diepgravender begrip van dit complexe fenomeen krijgen.

Dit boek richt zich op twee algemene vraagstukken. Het eerste betreft de politisering van etnische tegenstellingen. De invulling van een etnische identiteit en de ervaring van een conflict met een andere etnische 
groep is niet statisch. De politieke competitie speelt een grote rol bij het aanzetten en versterken van etnische tegenstellingen. Aan uitbarstingen van etnisch geweld gaat vaak een 'totalisering' van een etnische identiteit vooraf. Gedurende een barrage van politieke speeches en propaganda wordt één aspect van iemands identiteit naar de voorgrond gehaald. Terwijl andere aspecten, zoals iemands sociale klasse, regionale achtergrond, gender, politieke overtuiging, naar de achtergrond worden gedwongen. Zo wordt de scheidslijn tussen Hutu's en Tutsi's, tussen christenen en moslims of tussen hindoes en moslims dé manier om zichzelf en anderen te classificeren, terwijl andere verschillen er minder toe gaan doen. Maar deze 'totalisering' gebeurt niet in alle etnisch diverse landen en ook niet in alle tijdsperiodes. De vraag is daarom onder welke omstandigheden politieke elites erin slagen om etnische tegenstellingen te politiseren, en onder welke omstandigheden hebben deze elites daar een belang bij?

Een tweede vraagstuk betreft de fase die na, soms tijdens, deze totalisering van een sociale tegenstelling plaatsvindt, de daadwerkelijke mobilisatie voor geweld. Het is bekend dat in veel gevallen sociale of politieke leiders een belangrijke rol spelen bij het aanmoedigen en legitimeren van geweld, maar we kunnen nog niet goed verklaren waarom politieke elites in staat zijn om grote groepen mensen voor geweld te mobiliseren die helemaal niet dezelfde politieke of materiële belangen bij dit geweld hebben. Hierdoor krijgen vooral de 'instrumentalistische' verklaringen voor geweld het karakter van een samenzweringstheorie, zo lijkt geweld een complot van leiders die alle andere mensen om de tuin leiden om hun eigen belangen te dienen. Horowitz betoogde in zijn brede studie naar etnisch conflict dan ook dat 'attention needs to be paid to developing theory that links elite and mass concerns and answers the insistent question of why the followers follow' (1985: 140). Politici kunnen gebruikmaken van de angsten en behoeften die er onder mensen leven, maar waarom en hoe slagen ze erin om daar succesvol op in te spelen?

Hiermee samenhangend is de vraag waarom geweld op sommige plaatsen wel uitbreekt, terwijl op andere plekken niets gebeurt. Brede analyses over, bijvoorbeeld, veranderende economische structuren in een land, of over een toegenomen politisering van etnische verschillen, kunnen aannemelijk maken waarom een land vatbaar voor geweld is geworden, maar ze kunnen niet verklaren waarom dat geweld zich niet gelijkmatig over een land verspreid, want waarom zijn sommige steden of streken veel gewelddadiger dan andere gebieden? Deze vraag zal in verschillende hoofdstukken aan bod komen. 


\section{De schaduw van de staat}

In de afzonderlijke hoofdstukken van dit boek zoeken de auteurs naar antwoorden op dit soort vragen door te kijken naar de specifieke relaties tussen staat en burger in de onderzochte regio. Zij betogen dat zowel het aanzetten tot geweld als ook de politisering van etnische tegenstellingen kan worden gezien als een product van de manier waarop de 'schaduw van de staat' functioneert. De'schaduw van de staat' is de 'verbinding' tussen maatschappij en staat die bestaat uit allerlei schimmige, veelvormige netwerken die formeel los van de staat staan, maar toch een groot deel van hun inkomen en status ontlenen aan hun verwevenheid met die staat. In veel delen van de wereld beantwoordt het dagelijkse functioneren van de staat nauwelijks aan het (westerse) weberiaanse ideaalbeeld van wat een staat zou moeten zijn. In die landen is de staat niet een doelmatig, centraal geleid instituut en bezit de staat slechts een zeer fragiel monopolie over het gebruik van geweld (Migdal, 2001). In de dagelijkse praktijk is de soevereiniteit van veel staten beperkt, doordat zij afhankelijk zijn van allerlei niet-statelijke organisaties om wetten te handhaven en beleid te kunnen uitvoeren. Bovendien concurreren staatsinstituties vaak met elkaar en werken ze elkaar tegen, waarbij de scheiding tussen wetgevende, uitvoerende en rechtsprekende macht lang niet altijd gehandhaafd wordt. Vooral antropologen hebben gewezen op de discrepantie tussen het 'idee' van wat een staat behoort te zijn en de feitelijke praktijk van zijn dagelijkse functioneren (Mitchell, 1991; Blom Hansen en Stepputat, 2001; Das en Poole, 2004).

Zakenlieden, clanleiders, politici, religieuze leiders of criminelen, die formeel gezien geen onderdeel van de staat uitmaken, hebben in de praktijk een grote invloed op de manier waarop de wetten en het beleid van de staat wordt uitgevoerd. Zij ontlenen die invloed aan hun status en goede contacten, en soms hun geld, waardoor ze vertegenwoordigers van de staat onder druk kunnen zetten en medewerking kunnen afdwingen. Maar die invloed ontlenen ze ook aan het feit dat de staat die 'schaduw' nodig heeft om effectief te kunnen handelen. Dankzij een samenwerking met allerlei niet-statelijke actoren kan de staat zijn gezag vergroten. De staat beperkt wel zijn eigen soevereiniteit door deze samenwerking, maar tegelijk kan de staat via deze contacten zijn invloed en slagkracht uitbreiden. Door de medewerking van hun 'schaduw' kunnen instituties makkelijker informatie inwinnen, hun beleid effectiever uitvoeren en op meer lokale medewerking rekenen. En meer geld verdienen, want vaak ontleent de 'schaduw van de staat' haar invloed ook aan het feit dat individuele ambtenaren veel geld kunnen verdienen door gehoor te geven aan de wensen van deze 'schaduwactoren'. De invloed die deze netwerken hebben op het functioneren van de staat is niet zozeer gebaseerd op juridische claims of publiek debat, maar op een uitruil van 
diensten en gunsten. Het gebruik van term civil society voor zulke netwerken zou versluieren dat deze schaduwnetwerken door heel andere afhankelijkheidsrelaties en belangen worden geleid dan die waarmee de term civil society meestal geassocieerd wordt (vergelijk Chatterjee, 2004).

De vijf studies laten zien dat deze 'schaduw van de staat' verschillende vormen kan aannemen. Üngör beschrijft hoe in het begin van de twintigste eeuw familieclans een belangrijke rol speelden in het publieke leven in Oost-Turkije; deze elkaar beconcurrerende clans vormden niet alleen de basis voor lokale organisaties, ze vormden ook het vanzelfsprekende aanspreekpunt voor vertegenwoordigers van een staat met een beperkte soevereiniteit. Zowel Van Klinken als Berenschot richten zich op het functioneren van lokale patronagenetwerken in respectievelijk Indonesië en India. Die netwerken helpen burgers om toegang te krijgen tot de voorzieningen en de diensten die de staat te bieden heeft. In beide landen zijn deze netwerken voor een groot gedeelte georganiseerd rond zowel religieuze, als regionale identiteiten. Vlassenroot en Büscher laten zien hoe in Congo etnische verschillen langzaam geïnstitutionaliseerd werden doordat Mobuto's regime lokale traditionele leiders wist te integreren in de patronagenetwerken. Vervolgens gingen etnische groepen zich organiseren in milities om hun belangen tegenover een steeds zwakker wordende staat te verdedigen. Boersema analyseert de intensiteit van de competitie om de toegang tot de staat in een district in Rwanda. Voorafgaand aan de genocide in het dorp Runda begonnen de lokale machtsverhoudingen te verschuiven, doordat een nieuwe politieke groepering een alternatief kanaal bood om toegang te verwerven tot het de machtscentrum in de hoofdstad Kigali.

De afhankelijkheid van de staat van deze schaduwnetwerken neemt steeds andere vormen aan en daarmee verschilt ook het karakter van deze netwerken per regio. In Indonesië en India spelen deze netwerken een belangrijke rol in een breed scala van overheidstaken. Van ordehandhaving tot het aanleggen van waterleidingen. In India is de lokale status van de verschillende 'intermediairs' zoals Berenschot die schetst, nauw gerelateerd aan hun vermogen om toegang te bieden tot middelen en diensten van de staat, terwijl zowel in het Oost-Turkije aan het begin van de twintigste eeuw als in Oost-Congo van de jaren negentig, de lokale leiders nog een zekere status en aanzien bezaten die niet alleen gebaseerd was op toegang tot een beperkt aanwezige staat. Vlassenroot en Büscher beschrijven hoe in Congo de staat langzaam uit elkaar begon te vallen, doordat lokale leiders hun controle over handelsstromen konden gebruiken om een onafhankelijke machtbasis op te bouwen.

Ook de personen die prominent zijn in de schaduw van de staat opereren per land anders. In India hebben politici een centrale positie in zulke netwerken, terwijl in zowel in Oost-Turkije als in Indonesië lokale 
bureaucraten een prominente rol speelden. In de provincie Gitarama in Rwanda maakten jongerenbewegingen, een rijke zakenman en zelfs een voetbalteam deel uit van de netwerken die toegang tot de staat boden. Een overeenkomst tussen deze verschillende gevalstudies is dat een uitruil van gunsten steeds centraal staat. Een terugkerend thema daarbij is dat de verschillende personen die in de schaduw van de staat functioneren met elkaar samenwerken in de verwachting dat verleende diensten zich in de toekomst terug zullen verdienen. De capaciteit van lokale leiders om toegang te bieden tot de staat en dus om het dagelijks functioneren van de staat te beïnvloeden blijkt steeds weer een belangrijk instrument te zijn om lokale medewerking of gehoorzaamheid van burgers te verkrijgen. Dat maakt sommige patronagenetwerken ook zo gevoelig voor veranderingen. Als leiders hun capaciteit verliezen om hun achterban te belonen is het voor burgers verleidelijk om hun loyaliteit te verschuiven naar een andere lokale leider die meer te bieden heeft.

Het ontstaan en functioneren van deze verschillende 'schaduwen' kan niet los worden gezien van de manieren waarop de staat zich in deze landen ontwikkelde. Ondanks de specifieke geschiedenis van postkoloniale landen is het werk van historisch sociologen, zoals Tilly (1985) en Elias (2000 [1939]), die zich slechts richten op Europese staatsvormingsprocessen, toch verhelderend om een inzicht te verkrijgen in de manier waarop staatsvormingsprocessen samenhangen met veranderende afhankelijkheidsrelaties binnen de schaduwnetwerken en de redenen voor deze netwerken om tot etnisch geweld aan te zetten. Juist doordat de staat slechts langzaam de capaciteit ontwikkelt om allerlei diensten te leveren, belasting te heffen en wetgeving te ontwikkelen, kunnen er allerlei netwerken rond de staat ontstaan. Naarmate de staat een vermogen ontwikkelt om diensten te bieden, wordt het steeds interessanter om een toegang tot deze groeiende staat te verwerven.

Tegelijkertijd profiteren deze netwerken ook van de beperkingen van de staat: juist doordat burgers moeilijk op eigen kracht toegang kunnen verkrijgen tot de diensten die de staat biedt, of doordat de staat beschikt over een beperkte politiemacht, zijn zowel burgers als staatsinstellingen aangewezen op deze schaduw van allerlei bemiddelaars, die zo invloed krijgen op het functioneren van de staat. En waar de staat slechts zeer beperkt aanwezig is, zoals in Oost-Congo, kunnen gewapende groepen controle over handelsstromen verwerven door de lokale bevolking 'bescherming' te beloven.

Het gezag van bemiddelende of alternatieve schaduwnetwerken in veel postkoloniale landen kan niet los gezien worden van de 'onnatuurlijke' manier waarop koloniale heersers de instituties van de staat parachuteerden in een vreemde samenleving: juist de gebrekkige verankering van de nieuwe staatsinstituties in de samenleving creëerde een 
behoefte aan netwerken die konden bemiddelen tussen staatsinstituties en de samenleving. Ook nationale en lokale economische ontwikkelingen hebben een invloed op het functioneren van de schaduw van de staat. In zowel Rwanda als Indonesië danken de schaduwnetwerken hun prominente plaats mede aan het feit dat er voor armere delen van de bevolking weinig werkgelegenheid is. Dat maakt deze netwerken aanlokkelijk omdat inkomen en de overheidsbanen vaak alleen via deze schaduwnetwerken verkregen kunnen worden.

De schaduw van de staat kan gezien worden als een arena waarin verschillende actoren samenwerken en met elkaar concurreren om controle te verwerven over de middelen van de staat. Het feit dat politici er soms voor kiezen om nauwe banden met criminelen te onderhouden in bijvoorbeeld India kan worden gezien als een reactie op het onvermogen van de staat wetten te handhaven en veiligheid te garanderen. Dat politieke intermediairs zich inspannen om hun invloed op het ambtelijk apparaat te vergroten, zoals in India en Rwanda, kan gezien worden als een reactie op de beperkte capaciteiten van de staat om voorzieningen te bieden.

Het cruciale punt is dat, terwijl dit soort strategieën ingegeven wordt door de sterktes en zwaktes van een staat, deze strategieën de sterktes en zwaktes van de staat ook reproduceren. Doordat bijvoorbeeld politici ervoor kiezen hun greep op het ambtelijk apparaat te versterken, verkleinen zij de capaciteit van staatsinstanties om een universele toegang tot staatsvoorzieningen te bieden. En doordat politieke netwerken gaan aanschurken tegen criminele netwerken, maken zij het de staat steeds moeilijker om de wet te handhaven. Deze beschermingbiedende gangsterbendes dragen niet bij aan de ontwikkeling van de staat zoals Tilly (1985) die voor Europa omschreef. Hij betoogt immers dat de capaciteit van prille staten zich kan ontwikkelen, dankzij zowel dreiging als bescherming die de staten boden. Door zowel bescherming als de noodzaak voor bescherming te creëren konden staten zowel financiële middelen als de autoriteit verkrijgen, waardoor deze zich verder ontwikkelden. De gangsterbendes die in veel postkoloniale staten opereren, ondermijnen de autoriteit van de staat. Zoals Van Klinken opmerkt: 'the system is kept permanently incapacitated because so many profit from its incapacity' (Van Klinken, te verschijnen: 12).

\section{Waarom volgen de volgers?}

Terug naar het etnisch geweld. Wat heeft dit alles te maken met het begrijpen van uitbarstingen van etnisch geweld? De analyses in dit boek laten zien dat aandacht voor het functioneren van de schaduw van de staat en de structuren die dit functioneren beïnvloeden kan helpen om het uitbreken van etnisch geweld te begrijpen (zie Berenschot, 2009). 
Ten eerste richten die analyses zich op de dagelijkse interactie tussen staat en maatschappij om zo de motivaties van deelnemers van het geweld beter te begrijpen. Het dagelijkse functioneren van de schaduw van de staat creëert afhankelijkheidsrelaties tussen verschillende actoren die, ten tijde van spanningen, mensen kunnen motiveren om een bijdrage te leveren aan het organiseren en plegen van geweld. Zo kunnen we de tegenstelling tussen 'aanstichter' en 'dader' in veel literatuur over etnisch geweld overbruggen. Het dagelijkse functioneren van de schaduw van de staat bevordert voor lagere kaders de stimulans om de suggesties van elites met meer overgave na te leven dan deze elites eigenlijk hadden bedoeld. De motieven van deelnemers aan etnisch geweld komen vaak helemaal niet overeen met de motieven van hun leiders. Kalyvas (2003) betoogt dat in burgeroorlogen lokale deelnemers vaak veel meer worden gedreven door de mogelijkheid om hun lokale competities en vetes uit te vechten dan door de algemenere ideologie die hun leiders uitdragen.

Zowel Van Klinken als Berenschot betogen dat patronagenetwerken niet alleen een rol speelden bij de mobilisatie voor geweld, maar dat de uitruil van gunsten in deze netwerken ook motiveerde om deel te nemen aan het geweld. Üngör spreekt in dit geval van een 'risico van sterke bindingen'. De afhankelijkheid van lokale elites in Oost-Turkije van het politieke centrum leidde tot een situatie waarbij mannen deelnamen aan massamoord in ruil voor financiële en politieke gunsten van het regime. In Rwanda lijkt de rekrutering van jongeren in de radicale jongerenbeweging Interahamwe niet alleen ingegeven door haat tegen Tutsi's, maar ook door de mogelijke baantjes die de jongerenbeweging kon bieden.

Ten tweede suggereren de analyses in dit boek dat de netwerken die de verschillende uitbarstingen van geweld mogelijk maakten, niet zijn opgezet met het bewuste doel om tot geweld te kunnen aanzetten, zoals Brass (2003) had betoogd. Maar dat de netwerken die etnisch geweld mogelijk maakten ook als patronagenetwerken functioneerden. Zo laat Üngör zien hoe in Oost-Turkije de clanstructuur een belangrijk instrument bood om mensen te mobiliseren om de Armenen te vermoorden. Doordat clans een belangrijke rol speelden in het sociale en politieke leven van de regio Diyarbekir, konden via clans gemakkelijk mensen gemobiliseerd worden. Deze stad was volgens Üngör gewelddadiger vanwege de competitie tussen lokale clans die hun relaties met lokale machthebbers zeker wilden stellen. Voor de Congo laten Vlassenroot en Büscher zien hoe de organisatie van patronagenetwerken via dergelijke organisaties bijdroeg aan het opdrijven van de etnische spanningen. Op Ambon, Indonesië, speelden de instellingen van de protestantse kerk volgens Van Klinken een rol tijdens de mobilisatie van het etnische geweld, 
terwijl deze religieuze netwerken ook gebruikt werden om banen bij de overheid te verkrijgen.

Ten derde bieden de hoofdstukken inzicht in de manier waarop etnische verschillen soms langzaam gepolitiseerd raken en tot spanningen en geweld leiden. De mate waarin de interactie tussen staat en maatschappij verloopt via etnische netwerken kan de dynamiek achter het oplopen van spanningen tussen bevolkingsgroepen helpen begrijpen. In een recente kwantitatieve studie naar het uitbreken van burgeroorlogen concluderen Wimmer et al. (2009) dat de uitbraak van burgeroorlogen te maken heeft met de rol die etniciteit speelt bij het vergemakkelijken of blokkeren van de toegang tot de staat. Een dergelijke analyse ligt in de lijn met de analyses in dit boek: door de structuur van de netwerken tussen staat en burgers te bestuderen, kunnen we beter begrijpen waarom etnische scheidslijnen een zo prominente positie kunnen krijgen. Daar waar patronagenetwerken zijn georganiseerd op basis van etnische scheidslijnen in plaats van, bijvoorbeeld, klassenverschillen, krijgt de competitie om schaarse overheidsbanen en voorzieningen het karakter van een competitie tussen etnische bevolkingsgroepen.

Als de toegang tot de staat georganiseerd is rond etnische loyaliteiten, dan wordt het bestaan van een andere etnische groep op zich al een bedreiging van de kans om een overheidsbaan te krijgen of een kind naar een goede school te sturen. Dan vormt een lid van een andere etnische groep een bijna persoonlijke bedreiging voor maatschappelijk succes. Zo laten Vlassenroot en Büscher in hun historische analyse zien hoe de organisatie van patronagekanalen langs lijnen van etniciteit heeft bijgedragen aan het creëren van spanningen tussen etnische groepen. De bewuste strategie van politieke elites om de steun van de achterban eerst te cultiveren via traditionele leiders en daarna via etnische organisaties, creëerde een dynamiek die de rol van etnische scheidslijnen in het dagelijks leven steeds verder consolideerde. Op vergelijkbare manier laat Van Klinken zien dat dominantie van protestanten in de politieke partij PDI-P leidde tot spanningen toen er verkiezingen werden georganiseerd.

Deze benadering van etnisch geweld illustreert dat etnisch geweld niet goed is te begrijpen als we ons zouden beperken tot een analyse van hedendaagse politieke competitie en huidige sociale tegenstellingen. Het ontstaan van etnische spanningen en de wijze waarop de schaduw van de staat met deze spanningen omgaat, kan immers niet los gezien worden van de historische ontwikkelingen van staten en de wijze waarop nationale economieën met elkaar verweven zijn geraakt. Het bestaan van een schaduw van de staat en het soort competitie binnen deze netwerken is een product van de specifieke wijze waarop staten zich hebben ontwikkeld. De analyses in dit boek suggereren dat door de wijze waarop 
staatsinstituties geleidelijk ingebed zijn geraakt in de samenleving een politieke arena is gecreëerd die de politieke exploitatie van etnische tegenstellingen beloont. Dat suggereert dat etnisch geweld niet snel tot

het verleden zal gaan behoren, want de politieke dynamiek die leidt tot etnische spanningen zijn niet alleen het gevolg van de keuzes van politieke leiders, maar ook van het karakter van staten en het karakter van de netwerken rond hun instellingen. Deze bredere structuren zijn het product van een langzame evolutie. Wellicht heeft de herhaalde oproep om massaal geweld 'nooit meer' te laten gebeuren enig ontmoedigend effect en wellicht kunnen projecten rond peacebuilding en interfaith dialogue bevolkingsgroepen daadwerkelijk dichter tot elkaar brengen, maar de structuren die politieke exploitatie van etnische tegenstellingen profijtelijk maken zijn hardnekkig en moeilijk te bestrijden.

\section{Noot}

1 Zie Marshall's 'Major Episodes of Political Violence' op http://www.systemicpeace. org/warlist.htm. Zie ook Stewart en Brown, 2008.

\section{Literatuur}

Appadurai, A. (1998). Dead certainty. Ethnic Violence in the era of globalization. Development and Change, 29, 4, 905-925.

Azar, E. (1990). Protracted Social Conflict. An Analytical Framework. In The Management of Protracted Social Conflict. Aldershot: Dartmouth Publications.

Berenschot, W. (2009). Riot Politics. Communal Violence and State-Society Mediation in Gujarat, India. Proefschrift Universiteit van Amsterdam.

Blok, A. (2001). Honour and Violence. Cambridge: Polity Press.

Blom Hansen, T. (2001). Wages of Violence. Naming and Identity in Postcolonial Bombay. Princeton: Princeton University Press.

Blom Hansen, T. (2005). Sovereigns Beyond the State. On Legality and Public Authority in India. In R. Kaur (ed.), Religion, Violence and Political Mobilisation in South Asia. New Delhi: Sage Publications.

Blom Hansen, T. en F. Stepputat (2001). Introduction. In States of Imagination. Ethnographic Explorations of the Postcolonial State. Durham: Duke University Press.

Brass, P. (2003). The Production of Hindu-Muslim violence in contemporary India. Seattle, Wash.: University of Washington Press.

Chatterjee, P. (2004). The Politics of the Governed. Reflections on Popular Politics in Most of the World. New York: Columbia University Press.

Collier, P. en A. Hoeffler (2004). Greed and grievance in civil war. Oxford Economic Papers, 56, 563-595. 
Das, V. en D. Poole (ed.) (2004). Anthropology in the Margins of the State. Santa Fe: School of American Research Press.

Elias, N. (2000 [1939]). The Civilizing Process. Sociogenetic and Psychogenetic Investigations. Malden: Blackwell Publishing.

Fearon, J. en D. Laitin (2000a). Ordinary Language and External Validity. Specifying Concepts in de Study of Ethnicity, Annual Meetings of the American Political Science Association. October, 20-22.

Fearon, J. en D. Laitin (200ob). Violence and the Social Construction of Ethnic Identity. International Organization, 54, 4, 845-877.

Fearon, J. en D. Laitin (2003). Ethnicity, Insurgency, and Civil War. The American Political Science Review, 97, 75-90.

Geertz, C. (1963). The Integrative Revolution. Primordial sentiments and Civil Politics in the New States. In C. Geertz (ed.), Old Societies and New States: The Quest for Modernity in Asia and Africa. New York: Free Press.

Harbom, L. en P. Wallensteen (2007). Armed Conflict, 1989-2006. Journal of Peace Research, 44, 5, 623-634.

Horowitz, D. (1985). Ethnic groups in conflict. Berkeley: University of California Press.

Horowitz, D. (2002). The Deadly Ethnic Riot. New Delhi: Oxford University Press.

Ignatieff, M. (1998). The warrior's honour: ethnic war and the modern conscience. London: Vintage.

Kakar, S. (1996). The Colors of Violence. Cultural identities, religion and conflict. Chicago: University of Chicago Press.

Kaldor, M. (2004). New \& Old Wars. Organized Violence in a Global Era. Cambridge: Polity Press.

Kalyvas, S.N. (2003). The Ontology of Action and Identity in Civil Wars. Perspectives on Politics, 1, 3, 475-494.

Kaplan, R.D. (1993). Balkan ghosts: a journey through history. New York: St. Martin's Press.

Kaplan, R.D. (1994). The Coming Anarchy. The Atlantic Monthly, 273, 2, 44-76.

Klinken, G. van en J. Barker (ed.) (2009). State of Authority. Ithaca: Cornell University Press.

Mann, M. (2005). The Dark Side of Democracy. Cambridge: Cambridge University Press.

Migdal, J. (2001). State in Society: studying how states and societies transform and constitute one another. Cambridge: Cambridge University Press.

Mitchell, T. (1991). The limits of the state: beyond statist approaches and their critics. American Political Science Review, 85, 1, 77-96.

Nussbaum, M. (2007). The clash within. Democracy, religious violence, and India's future. Cambridge: Belknap Press.

Pandey, G. (1992). The Construction of Communalism in Colonial North India. Delhi: Oxford University Press. 
Reno, W. (2000). Clandestine Economies, Violence and States in Africa. Journal of International Affairs, 53, 2, 433.

Roy, B. (1994). Some trouble with cows: making sense of social conflict. Berkeley: University of California Press.

Stewart, F. en G. Brown (2007). Motivations for Conflict. Groups and Individuals. In C.A. Crocker, F.O. Hampson en P. Aall (eds.), Leashing the Dogs of War. Conflict Management in a Divided World. Washington: United States Institute of Peace.

Tambiah, S. (1996). Leveling crowds: ethnonationalist conflicts and collective violence in South Asia. Berkeley: University of California Press.

Tilly, C. (1985). War Making and State Making as Organized Crime. In P. Evans, D. Rueschemeyer en T. Scocpol (Eds.), Bringing the State Back in. New York: Cambridge University Press.

Valentino, B.A. (2004). Final Solutions. Mass Killing and Genocide in the Twentieth Century. Ithaca: Cornell University Press.

Veer, P. van der (1994). Religious Nationalism. Berkeley: University of California Press.

Wilkinson, S.I. (2004). Votes and violence. electoral competition and ethnic riots in India. Cambridge: Cambridge University Press.

Wimmer, A., L.E. Cederman en B. Min (2009). Ethnic Politics and Armed Conflict. A Configurational Analysis of a New Global Data Set. American Sociological Review, 74, april, 316-337. 


\title{
Massamoord en lokale elites in Turkije, | 9 |3-19|8'
}

\author{
Uğur Ümit Üngör
}

\section{Genocidale processen: nationale visie en lokale interpretatie}

Dit hoofdstuk richt zich op de vraag hoe op lokaal niveau de massale moord op de Turkse Armeniërs aan het begin van de twintigste eeuw is verlopen. Om dat te beoordelen zal eerst een historisch overzicht worden geschetst van de politieke krachten die in deze periode Turkije hebben vormgegeven, en zullen vervolgens de lokale machtsverhoudingen in een bepaalde provincie worden besproken.

In de periode 1850-1918 bestonden er twee typen wereldrijken. Het eerste type staat bekend als het West-Europese maritieme rijk met grote overzeese koloniale bezittingen. Deze imperia waren sinds de zestiende eeuw uitgegroeid tot een aanzienlijke omvang en waren rond 1900 de leidende militaire en economische machten in de wereld. Groot-Brittannië, Portugal, Spanje, Frankrijk en Nederland (en later, in mindere mate, België en Duitsland) waren de belangrijkste landen die hun staten tot grote en machtige imperia hadden ontwikkeld. Een tweede, ouder type wereldrijk staat bekend als het uitgestrekte, multi-etnische dynastieke landrijk. Deze voornamelijk agrarische samenlevingen werden bestuurd door gecentraliseerde bureaucratieën en absolute monarchieën. Rond 1900 bestonden nog ten minste vier belangrijke dynastieke landrijken: het Qing Rijk in China, het Ottomaanse Rijk, het Russische Rijk en het Habsburgse Rijk. Terwijl de maritieme wereldrijken rond 1900 in hoog tempo aan kracht wonnen, zouden de andere vier imperia binnen twintig jaar ten onder gaan. Aan het einde van de negentiende eeuw was de relatie tussen de maritieme wereldrijken en de landrijken manifest ongelijk. Het was dan ook geen verrassing dat de westelijke landrijken alle drie als verliezers uit de Eerste Wereldoorlog kwamen.

De gebruikelijke interpretatie van de Eerste Wereldoorlog als een 
oorlog tussen West-Europese staten is recent bekritiseerd als te nauw en te eurocentrisch. Historici besteden in modern onderzoek daarom ook aandacht aan de niet-Europese aspecten van de wereldoorlog, zoals de bijdrage die koloniale troepen hebben geleverd aan de oorlogshandelingen, het Aziatische en vooral Afrikaanse front, en de complexe deelname van het Ottomaanse Rijk aan de oorlog (Strachan, 2001: 496-643). Andere onderzoekers suggereren dat de Eerste Wereldoorlog misschien een onderdeel was van een langere crisis in het Europese statenstelsel, een argument dat in twee subargumenten uiteenvalt. Enerzijds grijpt dit terug op een oudere gedachte dat de periode 1870-1945 gekenmerkt kan worden als een 'Europese burgeroorlog'. Anderzijds is de visie ontstaan dat het continuüm van crisis en geweld zich uitstrekt van de Balkanoorlogen van 1912-1913 tot de Grieks-Turkse oorlog en de Russische burgeroorlog die in 1923 tot een einde kwamen. In deze interpretatie worden de Balkanoorlogen deels gezien als voorbode van de Eerste Wereldoorlog en de oorlogen in Turkije en Rusland als nasleep ervan (Bloxham, 2008).

$\mathrm{Al}$ in dat decennium is op grote schaal door verschillende regimes, legers en paramilitaire groepen massaal geweld tegen ongewapende burgers uitgeoefend. Bezetting, verzet en collectieve (weer)wraak schiepen situaties en constellaties die geweld tegen burgers voortbrachten. Zo kwamen tijdens de Balkanoorlogen, dus nog voor de Eerste Wereldoorlog, bij de vervolging en verdrijving van Ottomaanse Balkan-moslims tienduizenden mensen om in pogroms en massa-executies. Dorpen van moslims werden in brand gestoken en hun bezit werd geroofd door Bulgaarse en Servische milities (Boeckh, 1996: 162-174). De conflicten op de Balkan kenmerken zich voornamelijk door 'etnische zuiveringen', ofwel gedwongen migratie en verdrijving van groepen mensen op basis van hun afkomst (Lieberman, 2006: 53-79). Tijdens de Eerste Wereldoorlog organiseerden de Russische autoriteiten deportatie- en onteigeningscampagnes tegen 'vijandelijke minderheden'. Het Russische leger beging in het frontgebied pogroms tegen Galicische Joden (Lohr, 2003; Prusin, 2005: 53-79).

De Armeense genocide was misschien de meest brute en systematische vorm van massaal geweld tijdens de oorlog. Binnen het tijdsbestek van een jaar werd ongeveer een miljoen Armeniërs vermoord. Op de Balkan werd wederom grootschalig geweld uitgeoefend tegen burgers, bijvoorbeeld door het Oostenrijk-Hongaarse leger tegen Servische krijgsgevangenen en de Servische bevolking (Kramer, 2007: 140-4). Maar ook na de oorlog bleef geweld tegen non-combattanten een dominant patroon van reguliere en irreguliere oorlogvoering. De buitengewoon destructieve Russische burgeroorlog (1917-1923), die uiteindelijk de bolsjewieken aan de macht zou brengen, is treffend een 'crisiscontinuüm' genoemd. Deze oorlog kostte aan bijna 13 miljoen ongewapende burgers het leven 
en liep op de Kaukasus uit op een regelrechte etnische vernietigingsoorlog tussen Armeniërs en Azeri (Holquist, 2002). De Tweede Wereldoorlog staat bekend als de meest totale en genocidale oorlog ooit, maar ook de periode 1912-1923 is onmiskenbaar van belang voor de studie van massaal geweld.

Deze langdurige crisis in de tussen- en binnenstatelijke verhoudingen in Europa heeft ongetwijfeld bijgedragen aan de brutalisering van de politieke cultuur in deze samenlevingen. Oorlog, staatsdesintegratie en vervolging gingen immers gepaard met veel geweld tussen en binnen staten. Niet alleen kwamen miljoenen soldaten in reguliere oorlogshandelingen om het leven, ook werden honderdduizenden ongewapende burgers slachtoffer van verdrijvingen, massamoord en andere vormen van vervolging door hun eigen staten. De invloed van het verloop en de afloop van dit geweld op het ontstaan van autoritaire regimes in het interbellum kan bepalend worden genoemd. Jonge elites met radicale politieke ideeën kwamen door revoluties aan de macht: het nazisme in Duitsland en het stalinisme in de Sovjet-Unie zijn de twee bekendste voorbeelden. Deze twee regimes zijn vooral in de jaren dertig en veertig verantwoordelijk geweest voor ongekende processen van massaal geweld tegen tientallen miljoenen burgers. Zo is de lijst van misdaden onder Stalin angstaanjagend lang: de systematische executies van 'vijanden van het volk', de vernietiging van de 'kulakken', de hongersnood in de Oekraïne, de massa-executie van Poolse militairen in Katyń, de deportaties van complete etnische groepen uit hun thuisland, en de massale verdrijvingen van Duitsers aan het einde van de Tweede Wereldoorlog zijn slechts enkele voorbeelden. Het strafblad van de nazi's is minstens even misdadig met euthanasieprogramma's, georganiseerde massamoorden tegen de joden, Roma en Sinti, Polen, Sovjetkrijgsgevangenen, homoseksuelen en vele andere ongewapende burgers. Het einde van het nationaal-socialisme in 1945 en het stalinisme in 1953 bracht een abrupt einde aan dit tijdperk van massaal geweld in Europa (Kershaw, 2005: 107123).

Deze kolossale misdaden zetten de Pools-joodse jurist Raphael Lemkin (1900-1959) ertoe een nieuw begrip te introduceren: genocide. Lemkin definieerde dit begrip in 1944 als 'a coordinated plan of different actions aiming at the destruction of essential foundations of the life of national groups, with the aim of annihilating the groups themselves' (Lemkin, 1944: 79-95). Volgens Lemkin was genocide een nieuw, modern fenomeen dat zich onderscheidt van andere vormen van massaal geweld (inclusief massamoord), omdat in genociden individuen niet op basis van hun individuele eigenschappen of zelfs deelname in groepsdaden worden vervolgd, maar louter op basis van hun veronderstelde of toegeschreven lidmaatschap van een groep. Zo schrijft hij verder: 'Genocide is 
directed against the national group as an entity, and the actions involved are directed against individuals, not in their individual capacity, but as members of the national group.' Na de oorlog bepleitte Lemkin bij de Verenigde Naties de strafbaarstelling van de uitvoerders van een genocide als aparte internationale misdaad. Zijn activisme wierp zijn vruchten af toen op 9 december 1948 het Verdrag inzake de Voorkoming en de Bestraffing van Genocide werd getekend. Ondanks de goede bedoelingen van Lemkin en andere juristen is het verdrag een mislukking te noemen. Het gemak waarmee politieke elites in Cambodja, Rwanda, Joegoslavië en Darfur genocidaal geweld konden ontketenen toont enerzijds dat het moeilijk is om inachtneming van het verdrag af te dwingen - het internationaal recht lijkt simpelweg niet opgewassen te zijn tegen de machtspolitiek van staten. Anderzijds hebben de processen van de verschillende VN-tribunalen aangetoond dat het minstens zo gecompliceerd is om leidinggevende individuen te veroordelen voor genocide.

In de afgelopen zestig jaar heeft de sociale wetenschap succes geboekt in het begrijpen van genocidale processen. De eerste publicaties over genocide dateren al uit de jaren zeventig. Sindsdien is het aantal publicaties exponentieel gegroeid en is genocidenstudies tegenwoordig, met drie vaktijdschriften en onderzoeksinstituten in Noord-Amerika en Europa, een respectabel specialisme te noemen. Drie belangrijke vragen staan centraal in dit veld. Allereerst, wat zijn de oorzaken van een genocidaal proces? Ofwel: hoe komt een proces van stelselmatige vernietiging van een categorie mensen op gang? Ten tweede, hoe ontwikkelt een genocidaal proces zich? Er zijn sterke aanwijzingen dat, als een dergelijk proces eenmaal in gang is gezet, het zijn eigen dynamiek ontwikkelt. Hoe gaat dat precies in zijn gang op zowel het meest collectieve als op het individuele niveau? Tot slot is het belangrijk om te onderzoeken wat de consequenties van genociden zijn. Hoe leven daders, slachtoffers en omstanders verder na een genocide? Hoe verwerken zij de traumatische gebeurtenissen? Of gebeurt dat juist nauwelijks? Naar al deze vragen, onder andere het verloop van afzonderlijke genociden zoals de vernietiging van de Ottomaanse Armeniërs in 1915, de genocide in Cambodja van 1975-1979, en de massamoorden op Bosniërs is veel nuttig onderzoek verricht. Ook over bepaalde aspecten van genocidale processen is inmiddels veel bekend. Er is zowel afzonderlijk als vergelijkend onderzoek verricht naar de omslag van een min of meer 'normale' burgermaatschappij naar een vervolgingsmaatschappij, de beweegredenen van de 'normale' daders, de macht en werking van charismatische leiders en de gender-specifieke aspecten van het geweld.

Een belangrijk en in het huidige onderzoek tot nog toe enigszins verwaarloosd aspect is de relatie tussen centrale besluitvorming en lokale uitkomsten van deze besluitvorming. Genociden vertonen vaak opmer- 
kelijke regionale verschillen. Hoe is deze variatie in vervolgingsintensiteit en ontwikkelingsgang te verklaren? Het klassieke model van genocidale processen legt dit uit aan de hand van de dynamiek binnen de kringen van de centrale machthebbers. In deze top-down-interpretatie worden regionale vertragingen verklaard uit de wil van de elite. Deze theorie is op kritiek gestuit van onderzoekers die bottom-up-theorieën meer geschikt achten voor de verklaring van lokale verschillen. Volgens hen initiëren juist lokale elites vaak de eerste vervolgingsfase en ontwikkelt zich dan pas langzaam een radicalisering. De relatie tussen deze twee processen, centraal beleid en lokaal resultaat, zullen complexer zijn dan deze dichotomie suggereert, maar een alomvattende theorie van genocidale processen zou deze tegenstelling tussen sturing van bovenaf en lokale initiatieven moeten integreren om tot bevredigende antwoorden te komen. Dit hoofdstuk poogt hieraan een bijdrage te leveren door het gedrag van lokale elites tijdens vervolgingsprocessen in het middelpunt van de analyse te plaatsen. Het is nuttig om eerst literatuur over het stalinisme en nazisme hierover te verkennen.

In de periode 1936-1938 organiseerden Stalin en de NKVD een reeks zuiverings- en vervolgingscampagnes tegen, soms vermeende, tegenstanders van de Sovjet-Unie. Deze episode staat bekend als de Grote Terreur en liep uit op een heksenjacht tegen vaak willekeurig gekozen burgers. Veel van deze slachtoffers werden gedeporteerd naar goelag-kampen of werden na een kort schijnproces geëxecuteerd. De schattingen van het aantal slachtoffers lopen uiteen van 900.000 tot 1,2 miljoen - wellicht zelfs meer (Werth, 2003: 215-239). Het verloop van deze vervolging is voor de studie van massaal geweld uiterst relevant, want in hoeverre was er sprake van regionale diversiteit in de jacht op 'vijanden van het volk'? Deze vraag kan niet beantwoord worden zonder de bestaande machtsstructuren te analyseren. Hoe lagen de machtsverhoudingen tussen Moskou en lokale elites onder Stalin? Historici hebben laten zien dat lokale elites voornamelijk regionale belangen behartigden door nationale, vaak ideologische, richtlijnen te interpreteren op een manier die voor de streek gunstig uitvielen. Deze elites waren tegenhangers van de nomenklatura, de eliteklasse van apparatsjiks die sleutelposities in de top van de bureaucratie bezetten en de verordeningen van Stalin letterlijk uitgevoerd wilden zien. Lokale elites hadden nauwelijks invloed op het verloop van de Grote Terreur. De bevelen kwamen van bovenaf en bepaalden voor het grootste deel de methode van de vervolging en de keuze van de slachtoffers. De enkele lokale elites die de belangen van de eigen streek nastreefden of weerstand boden tegen de draconische eisen van Moskou werden met bruut geweld bestreden door de NKVD (Rees, 2003: 9-36). In dit model van vervolging en massaal geweld was het de centrale staatsoverheid, in het bijzonder Stalin zelf, die van bovenaf zijn wil 
oplegde aan lokale elites en op die manier vorm en sturing gaf aan de vervolging.

De pendant van dit model is ontwikkeld in recent onderzoek naar de genocidale vervolging door de nazi's van allerlei categorieën mensen, in het bijzonder joden. Naast het nu achterhaalde debat tussen intentionalisten en functionalisten heeft er in het onderzoek naar de Shoah een discussie gewoed over de spanning tussen regionalisering en deregionalisering. Volgens sommigen is de Shoah niet alleen een product van de polycratie van de nationaal-socialistische staat, maar ook van een zeker regionalisme. Op verschillende maatschappelijke gebieden was er ruimte voor lokale machthebbers om hun zin door te drijven. Gedetailleerde regiostudies naar de jodenvervolging hebben verdieping gegeven aan het idee dat de relatieve autonomie van lokale elites aanzienlijk kon zijn (Gerlach, 1999; Pohl, 1996; Lower, 2005). Zo toont een vergelijking tussen het handelen van SS-commandanten van verschillende districten dat sommigen zoveel mogelijk joden in leven lieten en anderen juist zoveel mogelijk joden doodden (Browning, 1983: 73-85). Sommige onderzoekers opperen zelfs dat er zich tijdens de oorlog misschien niet één, maar meerdere Shoahs hebben afgespeeld. Zo was volgens hen de vervolging van de joden in Roemenië en in Kroatië grotendeels een autonoom project van lokale fascisten. In Oost-Europa werd geput uit bestaande anti-joodse sentimenten om bijvoorbeeld Oekraïners en Polen tegen joden op te hitsen en pogroms te steunen - een soortgelijke actie zou in Nederland hoogstwaarschijnlijk mislukt zijn (Gruner, 2005: 269294). Het is echter aannemelijk dat het vervolgingsproces structureel in handen lag van lokale elites. De Shoah was volgens deze benadering een lappendeken van kleinere vervolgingen die slechts zwak centraal werd aangestuurd. Dit kan de regionale variatie in het vervolgingsproces verklaren.

Hoe kunnen deze twee modellen worden toegepast op het massale geweld in Turkije onder leiding van de Jong-Turken? Allereerst is het van belang om te constateren dat tijdens de Jong-Turkse bestuursperiode (1913-1950) twee grootschalige vervolgingen zijn georkestreerd: de vervolging en moord op de Armeniërs in 1915 en de vervolging en deportatie van de Koerden in de jaren twintig en dertig. Elders is geargumenteerd dat in de eerste fase het handelen van de lokale elite bepalend is geweest voor het verloop van de vervolging (Üngör, 2009). Was de Armeense genocide minder centraal gestuurd dan voorheen werd gedacht? Of liggen andere mechanismen hieraan ten grondslag? 


\section{Lokale machtsverhoudingen en interetnische spanningen}

De recente publicatie van Talaat Pasja's Zwartboek heeft het debat over de kwantitatieve aspecten van het vernietigingsproces doen oplaaien. Talaat was als Turkse minister van Buitenlandse Zaken verantwoordelijk voor de moord op de Armeniërs. Het Zwartboek is gebaseerd op Talaats handgeschreven notitieboek dat door zijn weduwe in 1982 aan de Turkse journalist Murat Bardakçı is gegeven. Het biedt mogelijkheden om de regionale variatie te bestuderen, aangezien het per provincie deportatiestatistieken weergeeft. Mede hierom kan het enkele van de meest fundamentele vragen over de Armeense genocide beantwoorden, maar werpt het ook nieuwe vragen op. De statistieken tonen duidelijk wat experts al enige tijd hadden gesuggereerd: het vernietigingsproces vertoont verschillen tussen de westelijke en de oostelijke provincies van het Ottomaanse Rijk. Het gemiddelde dodental ligt in het oosten aanzienlijk hoger dan in het westen. Terwijl het percentage gedeporteerde en vermoorde Armeniërs 97 bedraagt in de oostelijke regio Diyarbekir, ligt in het westelijke Konya dit percentage op 'slechts' 61. Waarom was de vervolging van Armeniërs zo hevig in Diyarbekir? Ter verklaring zal de analyse zich richten op de vraag hoe de lokale Jong-Turkse elite in Diyarbekir zijn macht hanteerde en hoe dit de ontwikkeling van het genocidaal proces in die provincie kan hebben beïnvloed. De nadruk zal liggen op interetnische verhoudingen in Diyarbekir aan de vooravond van de Eerste Wereldoorlog.

Diep verankerd in de sociale structuren van Diyarbekir lagen overlappende en elkaar beconcurrerende netwerken van rijke en invloedrijke families van grootgrondbezitters die als 'aristocratie' zouden kunnen worden betiteld. Deze clans speelden historisch de rol van lokale machthebbers en genoten privileges die door de sultan waren toegekend. De buitengewoon machtige Pirinççizâde-dynastie stak boven de andere families uit door hun politieke en economische macht; zij bezaten grote landerijen in de provincie, waaronder de rijstvelden ten westen van de stad Diyarbekir. De Pirinççizâde-clan bezat wel dertig dorpen in de omgeving van Diyarbekir. De meeste notabele families, zoals de Ocak, Ekinci en Cizrelizâde, leefden in grote villa's binnen de stadsmuren. Deze families waren grotendeels Turks. Maar ook belangrijke Koerdische families, zoals de Zazazâde en Cemilpaşazâde, woonden in de stad. Invloedrijke stamhoofden uit de provinciesteden van Diyarbekir bezaten vaak een huis in de stad en pendelden heen en weer. De Cemilpaşazâde waren in het bijzonder belangrijk vanwege hun pioniersrol in het Koerdische nationalisme (Özoğlu, 2004: 103-107).

Hoewel al deze families met elkaar in concurrentie verkeerden om status, politieke en economische macht, waren zij vaak ook door familiebanden aan elkaar verbonden. De Cizrelizâde waren schoonfamilie 
van de Yasinzâde, de Müftüzâde waren deels door bloed en deels door huwelijken verwant aan de Direkçizâde en enkele vrouwen uit de Zazazâde-familie waren getrouwd met mannen uit de Gevranizâde-familie. De Koerdische Cemilpaşazâde waren schoonfamilie van de Azizoğlu en de machtige Pirinççizâde waren weer aan enkelen van deze families verwant door echtelijke banden. Deze families vormden gezamenlijk een klasse van gegoede landbezitters die hun economische macht konden omzetten in politieke macht. De lokale staatsoverheid, waaronder de bureaucratie, politie en soms de gendarmerie, stond zo min of meer onder controle van deze families.

De stadspolitiek in Diyarbekir kon beslissend zijn voor de politiek in de regio. De concurrentie om macht tussen deze families kon, parallel aan de tegenstellingen in de politiek op nationaal niveau, toenemen dan wel afnemen. Deze dynamiek bracht vormen van corruptie en nepotisme voort, die door de Britse reiziger David Fraser in 1909 werd omschreven als 'misgovernment [...] within its walls there is neither justice for the righteous nor protection for the weak' (Fraser, 1909: 180-181). Deze condities waren een gevolg van de scherpe concurrentie tussen de clans, en de relatief zwakke centrale staatsautoriteit. De concurrentie bestond al decennia, zo niet eeuwen, voor de machtsgreep van de Jong-Turken. Zij was onderdeel van het dagelijks leven en de machtsstructuren in de stad en de provincie Diyarbekir en bepaalde veel facetten van het sociale verkeer.

De opkomst van het nationalisme en de massapolitiek in het Ottomaanse Rijk brachten spanningen met zich mee tussen klassen en tussen de politieke elites van etnische groepen. In de stad Diyarbekir werden de discussies die in Istanbul over nationale identiteit werden gevoerd met argusogen gevolgd. Naast de concurrentie tussen de families van islamitische notabelen ontstond nu ook een zekere concurrentie tussen de etnisch georganiseerde politieke partijen. Zo stelde de Jong-Turkse nationalist Şeref Uluğ van de Müftüzâde-clan voor een economische boycot te organiseren tegen de 'verraderlijke Armeniërs' om de economische macht van de moslims te versterken. Veel Diyarbekir-Armeniërs steunden de Dashnaktsutiun-partij, die op de lange termijn een vorm van Armeense autonomie ambieerde.

Belangrijke doelstelling in hun partijprogramma waren meer vrijheden en meer decentralisatie in het Ottomaanse bestuur van de oostelijke provincies, de invoering van het Armeens als officiële taal in het onderwijs en de bureaucratie, en een eind maken aan de wetteloosheid, ongelijkheid en geweld gepleegd door sommige Koerdische stammen tegen (Armeense) boeren. ${ }^{2}$ Het Koerdische nationalisme was niet zo goed georganiseerd en ontwikkeld als zijn Armeense tegenhanger en bestond voornamelijk uit intellectuelen en geestelijken. Op 19 september 1908 
richtten Koerdisch-nationalisten in Diyarbekir de Koerdische Vereniging voor Medewerking en Vooruitgang op. Volgens hun statuten streefde deze partij naar de versterking van de rechtsstaat, een einde aan intraKoerdische stammenconflicten, de ontwikkeling van het idee van een 'Ottomaanse identiteit', en het versterken van 'de harmonie en goede verstandhouding met haar Armeense, Nestoriaanse, en andere Ottomaanse medeburgers'.

De belangrijkste nationalistische groepering in Diyarbekir voor de Eerste Wereldoorlog was ongetwijfeld de Jong-Turkse partij: het Comité voor Eenheid en Vooruitgang (Committee of Union and Progress, İttihad ve Terakki Cemiyeti). Het eerste filiaal van de CUP werd geopend op 23 juli 1908 door de partij-ideoloog Ziyâ Gökalp die zelf uit het noorden van Diyarbekir kwam en tevens de afgevaardigde voor Diyarbekir was in het Centraal Comité, het centrale bestuursorgaan. Gökalp begon de krant Peyman te publiceren, sloeg daarin een gematigde toon aan en benadrukte de noodzaak tot het samenleven van de verschillende Ottomaanse onderdanen. Maar de ernstige crisis die het Ottomaanse Rijk vanaf het begin van de twintigste eeuw zou treffen maakte hier een einde aan en zou uiteindelijk ook de interetnische relaties in Diyarbekir grondig polariseren. De Jong-Turkse dictatuur in Istanbul oefende haar macht in de provincie uit door een netwerk van voornamelijk door de partij opgeleide leden van de clans in Diyarbekir. De meest invloedrijke CUP-leden in Diyarbekir waren zij die verwant waren aan de machtige Pirinççizâdeclan.

Een sleutelfiguur was de parlementariër Pirinççizâde Aziz Feyzi (18791933), van wie de vader in de lokale politiek naam had gemaakt. Hij had een opleiding doorlopen als bestuurder en zich opgewerkt in de gelederen van de lokale Jong-Turkse partij. Volgens een Duits rapport had Aziz Feyzi in 1911 zelfs een studiereis gemaakt naar Duitsland - reizen naar het buitenland was alleen voor de rijkste Ottomanen weggelegd. ${ }^{3}$ Namens vele andere notabelen in Diyarbekir had hij in het Ottomaanse parlement geprotesteerd tegen het plan om rijke en machtige grootgrondbezitters te onteigenen en de grond te verdelen onder arme boeren. De Ottomaanse crisis deed Feyzi radicaliseren tot een Jong-Turkse havik. Hij hield scherpe en vijandige discussies met de Armeense parlementariër Vartkes Serengulian (1871-1915), die hij onterecht beschuldigde van Armeens nationalisme en separatisme. Zijn anti-Armeense sentimenten werden sterker en in 1913 heeft hij hoogstwaarschijnlijk zijn rivaal in de verkiezingen, de Katholieke Armeniër Ohannes Kazazian, laten ombrengen (Rhétoré, n.d.: 59-6o). ${ }^{4}$ Toen hij de lokale verkiezingen won en afgevaardigde voor Diyarbekir werd, veroorzaakte dit grote onrust onder Armeense politici in de stad (Minassian, 1995: 90).

Het Ottomaanse verlies van de Balkan in 1913 zond een schokgolf 
door de Ottomaanse samenleving en polariseerde de interetnische relaties nog sterker. Alsof het verlies niet traumatisch genoeg was, werden in de loop van 1913 langzaam maar gestaag stappen gezet richting een 'hervormingsplan' om de Armeense 'kwestie' door het aanstellen van Europese inspecteurs 'op te lossen'. Deze oplossing zou tegemoet moeten komen aan de eisen van Armeense politieke partijen en onder andere in meer autonomie voor Armeniërs en Koerden resulteren. De Jong-Turkse regering in Istanbul, aan de macht gekomen door een staatsgreep na het verlies van de Balkan, wees deze eisen categorisch af en intrigeerden achter de schermen om het hervormingsplan te ondermijnen.

Na de bekendmaking van het plan stuurde de gouverneur van Diyarbekir een rapport aan de centrale overheid. In het rapport schrijft hij dat geruchten over het hervormingsplan sociale onrust veroorzaakte tussen christenen en moslims in Diyarbekir: 'de geruchten veroorzaken veel onmin en alarm onder de islamitische bevolking'. Speculaties in de pers dat het hervormingsplan was geaccepteerd en binnenkort uitgevoerd zou worden 'kwetsen de sentimenten van de moslims en hebben onlangs tumult doen ontstaan'. De gouverneur verklaarde dat de Turkse en Koerdische middenklasse vertrouwen had in de regering, maar 'niet onverschillig kan blijven ten opzichte van een kwestie die het bestaan en de toekomst van ons vaderland kan beïnvloeden'. De moslims, zo concludeerde hij in zijn rapport, zouden een hervormingsplan verwerpen en hij sprak zijn vrees uit dat een dergelijk scenario in de toekomst 'vreselijke consequenties' zouden kunnen hebben. ${ }^{5}$

Het hervormingsplan voorzag de vorming van twee nieuwe provincies uit de zes bestaande provincies, en de aanstelling van twee WestEuropeanen als bestuurders. Het plan werd geratificeerd in februari 1914 en, zoals de gouverneur had voorspeld, braken in de lente van dat jaar rellen uit tussen moslims en christenen in de bazaar en binnenstad van Diyarbekir. De moslims gaven uiting aan hun haat tegen de christenen door op muren anti-Armeense leuzen te kladden en christelijke symbolen zoals kruizen te beledigen met 'afgrijselijke schuttingtaal'. Wederom rapporteerde de gouverneur dat de situatie in Diyarbekir 'ongunstig voor christenen' was geworden en dat de Armeense gemeenschap zich 'volslagen radeloos' voelde. ${ }^{6}$ De Jong-Turken in de stad waren verantwoordelijk voor het scheppen van een anti-Armeens klimaat. In de zomer van 1914, toen de spanningen in Europa hoog opliepen, reisde de Armeens-Ottomaanse civiel inspecteur Mihran Boyadjian naar Diyarbekir en kwam onderweg de Jong-Turkse havik Pirinççizâde Aziz Feyzi tegen. Tijdens dit gesprek bedreigde Aziz Feyzi openlijk de Armeniërs. Boyadjian getuigde later als volgt. 
Onderweg spraken we in de wagen veel over politiek. Feyzi Bey liet het niet na om in de gesprekken enkele bedreigingen te uiten richting mijn geloofsbroeders. 'De Armeniërs,' herhaalde hij bitter, 'hebben zich tegen ons misdragen in onze moeilijke dagen van de Balkanoorlogen. Patriarch Zaven, de Katholikos van Etchmiadzin, en Nubar hebben geprobeerd buitenlandse interventie te forceren; dat zal jullie duur kosten mijn vriend, jullie toekomst is in gevaar.' (Yeghiayan, 1991: 479)

Tot slot waarschuwde Aziz Feyzi: 'Jullie zullen nu zien wat het betekent om hervormingen te eisen.' De radicalisering en polarisatie van politieke elites was een voorbode voor een diepe crisis in de interetnische relaties in Diyarbekir die nu de grens tussen haat en geweld had bereikt. Die grens werd in augustus 1914 overschreden toen de graanmarkt van Diyarbekir het toneel werd van brandstichting en massale plunderingen. Een al dan niet aangestoken brand creëerde een gelegenheidsstructuur waarin moslimhandelaren grootschalig de winkels van Armeense handelaren begonnen te plunderen. Het werd snel duidelijk dat de JongTurkse politiecommandant, Memduh Bey, had 'toegestaan dat Koerden en moslims de winkels van Armeniërs gingen plunderen'.7 Volgens Mihran Boyadjian was Memduh Bey de brand zelf begonnen om zo mogelijkheden voor plunderaars te scheppen (Yeghiayan, 1991: 480). De deelname aan de pogrom was breed. De passieve reactie van de lokale autoriteiten suggereert stilzwijgende goedkeuring, zo niet actieve organisatie van het geweld. De brand getuigde dus van de macht van de lokale moslimelite in Diyarbekir, want die elite had straffeloos een pogrom uitgevoerd tegen de Armeense elite in de stad. Omdat ze de lokale overheid controleerden, werden ze niet ter verantwoording geroepen door de centrale overheid. Die kon in het ongewisse worden gelaten, simpelweg worden genegeerd of zelfs toestemmen met de acties. Hier is dus al een afwijking te constateren: de lokale elite kon zich permitteren om hetzij nationaal beleid zelf zodanig vorm te geven dat het fundamenteel afweek van de norm, dan wel zelf hun eigen bewind te voeren.

In machtscentrum in Istanbul verwekte de Balkanoorlog en het verlies van het Europese deel van het imperium een diepgaande radicalisering in het Jong-Turkse denken over politiek. Gerechtigheid voor de vele Ottomaanse doden en vluchtelingen bleef uit en ook voorheen gematigde Jong-Turken raakten verbitterd. Hun perceptie dat deze catastrofe zich nooit zou mogen herhalen in de resterende territoria van het Ottomaanse Rijk, vooral het sterk Koerdische en Armeense oosten, zou een grondige normverschuiving teweegbrengen: desnoods grootschalig en gewelddadig ingrijpen in de samenleving was geen taboe meer en werd openlijk besproken tijdens vergaderingen in Istanbul. Deze radicalise- 
ring werd versterkt door een angst, wellicht zelfs een complex, van verlies. De angst voor territoriaal verlies werd een hardnekkige component van de laat-Ottomaanse en moderne Turkse politieke cultuur. Sommige Ottomanen voorzagen de naderende ondergang. In 1913 publiceerde de Armeense schrijver Aram Andonian een boek over de Balkanoorlogen. Hij schreef bezorgd dat 'het principe van nationaliteit' op de Balkan een ramp had veroorzaakt en in de oostelijke provincies onhoudbaar zou zijn. Daar woonden Turken, Armeniërs en Koerden immers door elkaar zonder dat de ene of andere groep ergens een meerderheid vormde.

\section{Ontvouwing van het genocidale proces}

De twee belangrijkste politieke gebeurtenissen die gewelddadig uiting gaven aan de Jong-Turkse frustraties waren de Jong-Turkse staatsgreep van 23 januari 1913 en het uitbreken van de Eerste Wereldoorlog. Beide gebeurtenissen zetten de Turks-Armeense betrekkingen nog verder onder druk. Op 23 januari 1913 liep een groep Jong-Turkse activisten de kamer binnen waar het Ottomaanse kabinet vergaderde, schoot de minister van Oorlog dood en eiste het aftreden van het kabinet. Na de staatsgreep werd uit de CUP-elite een nieuwe regering gevormd. De bureaucratie werd gevuld met aanhangers van de partij. Binnen enkele maanden was het CUP van een ondergrondse revolutionaire partij een regering geworden, met enkele achter de schermen functionerende militairen en politici. Enver liet zich op onwettige wijze tweemaal bevorderen en werd pasja (generaal) en Talaat werd aangesteld als minister van Binnenlandse Zaken. Uiteindelijk werd het Algemene Beraad van de partij belangrijker dan het parlement dat nog bijna voor een voldongen feit kwam te staan. Politiek gezien was het een weinig transparant geheel waarbij regels werden genegeerd en tegenstanders zonder scrupules gewelddadig uit de weg werden geruimd. Het CUP nestelde zich in een latente dictatuurpositie en brutaliseerde en depacificeerde de Ottomaanse politieke cultuur.

Another facet of the political revolution was the brutalization of political life. Once politics ceased to be the sport of the ruling classes the rules were changed accordingly. Under Abdulhamid death sentences were the exception not the rule. Dissent was made impotent through isolation and dissenters in exile could always recant. [...]. The Unionists were men of a different stamp. To them politics was much more than a game and having seized power they meant to hold on to it. To do so they were willing to use all possible means, so that repression and violence became the order of the day. Nothing was sacred in the pursuit of power and those 
guilty of dissent must be prepared to pay with their lives. (Ahmed, 1969: 163)

Ook in de media werd geweld verheerlijkt: nationalistische schrijvers schreven artikelen waarin expliciet uiting werd gegeven aan collectieve haat- en vernietigingsfantasieën, met name tegenover de nieuwe Balkanstaten (Gawrych, 1986: 303-330).

Door deel te nemen aan de Eerste Wereldoorlog hoopte het CUP de vele problemen in het land radicaal en grondig op te lossen. Vanaf de eerste dag van de oorlog werd het dictatoriale CUP-regime repressiever tegenover de oppositie. Afwijkend gedrag werd systematisch en meedogenloos bestreden. Het internationale hervormingsplan voor de oostelijke provincies werd geannuleerd nog voordat de twee Europese inspecteurs aan het werk konden (Davison, 1947: 481-505). Op 6 september 1914 beval Talaat het Ottomaanse veiligheidsapparaat om de lokale leiders van de Armeense politieke partijen nauwgezet 'te volgen en te observeren'. Volgens Talaat hadden deze zich ingelaten met 'agitatie en onrust' tegen de staat. ${ }^{8}$ De politiek van het CUP deed niet alleen op directe wijze de gelederen sluiten, ook veroorzaakte het een indirecte vorm van politieke homogenisering, omdat sommige ambtenaren zich niet meer identificeerden met de regering en vrijwillig ontslag namen. Op 12 november nam Süleyman Bustani, de protestants-Syrische minister van Handel, ontslag uit het kabinet als protest over wat hij zag als aanhoudende intimidatie door het CUP (Ahmad, 1982: 424). Dit gaf het CUP de gelegenheid deze bureaucratische posities te vullen met nationalisten.

De oorlog begon aan het oostelijke front toen de krijgszuchtige Enver Pasja, deels gedreven door expansionistische ambities richting het oosten en deels gedreven door veiligheidsoverwegingen, op 29 december 1914 het Russische leger probeerde aan te vallen bij het stadje Sarıkamıs. Tegen de aanwijzingen van zijn militaire adviseurs in stond Enver erop een cirkelbeweging uit te voeren dwars door de bergen van Kars. De Russische generaal Yudenich anticipeerde de flankeerbeweging van Enver en diende zijn troepen een zware slag toe. Uiteindelijk resulteerde Envers aanval in een mislukking met catastrofale gevolgen voor het Derde Leger, dat min of meer werd vernietigd. Van de 90.000 soldaten die waren begonnen aan de slag bij Sarıkamıs stierven circa 78.0oo manschappen, grotendeels door uitputting en bevriezing (Erickson, 2000: 51-74). Deze catastrofe bleek al vroeg in de oorlog een omslagpunt, omdat door dit verlies Oost-Anatolië voor een deel zou worden bezet door de Russen. De reguliere krijgsvoering ging gepaard met een guerrillaoorlog voorbij de fronten. In de winter van 1914 begonnen de paramilitairen van de Speciale Organisatie Russisch en Perzisch grondgebied te penetreren om de lokale moslimbevolking op te hitsen en te werven voor het Ottomaanse 
leger. In deze guerrillaoorlog vielen troepen onder leiding van commandanten als Yenibahçeli Nail, Deli Halit en Topal Osman in die gebieden Armeense dorpen aan. Dorpen werden geplunderd en verbrand, en er werd straffeloos gemoord. De Duitse ambassadeur Wangenheim was hiervan op de hoogte en schreef de kanselier dat de anti-Russische acties over de grens bij Erzurum vaak uitliepen op 'Übergriffen und Ausschreitungen' tegen Armeense dorpelingen. ${ }^{9}$

De CUP-partijtop verklaarde, om het gezichtsverlies te verhullen en de verantwoordelijkheid te ontlopen, dat het desastreuze verlies was veroorzaakt door Armeens verraad. Terugtrekkende Ottomaanse soldaten haalden met geweld en roof hun gram in Armeense dorpen. Na terugkeer van het front schreef Enver een brief aan de Armeense patriarch van Konya waarin hij zijn respect en bewondering voor de dapperheid van de Armeense soldaten in de slag om Sarıkamıs tot uitdrukking bracht. Enver gaf in de brief het voorbeeld van een sergeant Ohannes die was onderscheiden met een medaille voor bewezen moed (Lepsius, 1919: 161-162). Dit was wellicht niet wat Enver werkelijk over dit onderwerp dacht. In een persoonlijk gesprek met de uitgever van het CUP-partijblad beschuldigde Enver de Armeniërs bitter voor het militaire fiasco en stelde voor ze te deporteren naar een oord waar ze geen problemen zouden veroorzaken. Het verlies ontketende een golf aan vervolgingen, in het bijzonder in de grensprovincies Erzurum, Bitlis en Van. Op 26 december 1914 beval Talaat 'het ontslag van alle Armeense politiemannen, hoofdcommissarissen en staatsambtenaren, en de deportatie van eenieder die deze maatregelen tegenwerkt'. ${ }^{10}$ Deze ontwikkeling kenmerkte een verheviging van het wantrouwen van het CUP over de Armeense loyaliteit aan de Ottomaanse staat.

In februari en maart 1915 beval het CUP de ontwapening van alle Armeense soldaten in het Ottomaanse leger en hun tewerkstelling in arbeidsbataillons (amele taburları), die belast waren met 'Straßen- und Befestigungsarbeiten hinter der Front,' schrijft Pomiankowski die als Oostenrijkse luitenant tijdens de oorlog diende op verschillende fronten in Turkije (Pomiankowski, 1928: 93). Gezien het feit dat de overgrote meerderheid van de Armeense mannen gehoor had gegeven aan de oproep voor militaire dienst waren er tienduizenden arbeiders geworven. De manschappen die in deze bataillons werden opgenomen werden behandeld als ontrouwe elementen en dienstweigeraars. Een officiële verordening gebood hen 'koste wat kost' te beletten om de wapens op te nemen in het reguliere leger. De arbeidsbataillons werden onder erbarmelijke condities ingezet in de wegenbouw. De arbeiders werden in de regel begeleid door enkele soldaten of gendarmes. Veel van deze dienstplichtigen bezweken door uitputting, ziekten en mishandeling (Kévorkian, 1995: 289-303). 
De noodlottige gebeurtenissen in maart zouden bepalend zijn voor de toekomst van het Ottomaanse Rijk. De landingen op Gallipoli en de Russische aanval op Van zaaiden paniek bij de CUP-partijtop. In een gesprek met Henry Morgenthau verzekerde Talaat dat bij een doorbraak van de Britten in de Dardanellen het CUP de Aya Sofia zou opblazen en zich in het Anatolische binnenland zou terugtrekken, waarvandaan ze de Entente zouden weerstaan. Toen Morgenthau protesteerde tegen de voorgestelde vernietiging van de Aya Sofia lachte Talaat hem uit en verkondigde dat nog geen zes man in het CUP om het gebouw zouden treuren (Morgenthau, 2000: 132). De ontwikkelingen bekrachtigden de reeds bestaande angst voor een doemscenario waarin een potentieel Armeense desertie de weg zou plaveien voor een Russische invasie van Anatolië. Deze achterdocht leidde midden maart tot een serie vergaderingen van het Centrale Beraad in Istanbul, waarna aan dr. Bahaeddin Şakir zeggenschap werd gedelegeerd om af te rekenen met 'de interne vijanden'. De Speciale Organisatie werd gereorganiseerd, uitgebreid en onder zijn gezag geplaatst. Talaat gaf het leger bevel om 'zich te wenden tot het Derde Leger voor het nemen van maatregelen tegen Armeense acties'. ${ }^{11}$ Meteen hierop verordende hij een totale censuur tegen het Armeense dagblad Azadamart en beval de hoofdcommissaris van de Istanbulse politie om hun drukpersen te confisceren (Vierbücher, 1985 [1930]: 59).

In april 1915 deed zich een radicalisering van de vervolgingen voor. Langzaamaan werd geen onderscheid meer gemaakt tussen schuldige en onschuldige Armeniërs. Het beslissende moment werd bereikt in de cruciale slag om Van, die zowel voor de Ottomanen als voor de Russen zeer belangrijk was. Het front in Van was een totale oorlog: aan beide kanten werd met weinig onderscheid tussen burgers en militairen gemoord. Moslims werden door de gezamenlijke Russisch-Armeense troepen en christenen werden door de Ottomaanse troepen zonder pardon gedood (Reynolds, 2003; Minassian, 2009: 209-244). De anti-Armeense maatregelen op het nationale niveau werden nu steeds extremer en, onder invloed van de brutaliserende oorlog in Perzië en Oost-Anatolië, werd bij de toepassing ervan ook steeds meer geweld gebruikt. De kentering kwam toen in de nacht van 23 april 1915 Engelse en Australische troepen landden op het schiereiland Gallipoli (Gelibolu) om daar door te breken en te profiteren van het kardinale strategische belang van deze zeestraat. Het CUP begon meteen in paniek de hoofdstad te ontruimen. Op 24 april 1915 werden enkele honderden vooraanstaande mannen uit de elite van de Ottomaans-Armeense gemeenschap gearresteerd en naar de provinciestad Çankırı gedeporteerd. Vrijwel zonder uitzondering werden deze mannen binnen enkele weken doodgemarteld. Tegelijkertijd werden konvooien van de eerste groepen gedeporteerden uit het binnenland omgeleid naar Der el-Zor in de Syrische woestijn. De vervolgingen 
intensiveerden en werden uitgebreid tot het gehele Ottomaanse Rijk (Bloxham, 2002: 101-128). Zo zat in midden mei al de hele Armeense politieke, culturele, religieuze, en intellectuele elite van Diyarbekir in de gevangenis.

In april waren sommige Armeniërs al gedeporteerd uit hun woongebieden. Dit was tot dan toe nog geen landelijke campagne. De integrale deportatie van de gehele Armeense millet werd officieel bevolen op 23 mei 1915 door Talaat Pasja. Het bevel van Talaat voorzag, met minimale uitzonderingen, de deportatie van alle Armeniërs naar Der el-Zor en hij begon met de noordoostelijke provincies. ${ }^{12}$ Dezelfde dag spoorde hij de leiding van het Vierde Legerkorps aan om elke moslim die met een christen samenwerkte voor de krijgsraad te slepen. ${ }^{13}$ Het Derde Leger stond onder bevel van generaal Mahmud Kâmil Pasja, die een soortgelijk bevel had ontvangen. Zijn voorschriften dicteerden: 'de moslim die een Armeniër beschermt zal voor zijn huis worden geëxecuteerd en zijn huis zal worden verbrand (bir Ermeniyi tesahüp edecek bir Müslümanın hanesi önünde idam ve hanesi ihrak)'. De golf aan vervolgingen zette de Entente ertoe op 24 mei een gemeenschappelijke verklaring af te leggen waarin de vervolgingen werden veroordeeld. De verklaring bekritiseerde de 'crimes of Turkey against humanity and civilization' en beloofde 'that they will hold personally responsible [...] all members of the Ottoman government and those of their agents who are implicated in such massacres. ${ }^{14}$ De verblufte CUP-top, met name Talaat, probeerde hierop de deportaties te camoufleren en verzocht op 26 mei toestemming van de grootvizier om een Tijdelijke Deportatiewet te vervaardigen. Hoewel de deportaties toen al waren begonnen, ratificeerde de grootvizier de wet op 29 mei, waarna de wet de volgende dag officieel van kracht werd. Deze juridische maskering markeerde het officiële begin van de deportatie, die op dat moment in feite al een voldongen feit was. Hoewel het leger een aanzienlijke hoeveelheid gezag werd toebedeeld om de deportaties te organiseren, werd de dagelijkse leiding overgedragen aan het IAMM.15

Wat na deze organisatorische instructies volgde was de mobilisering van een enorme boerenbevolking die grotendeels op het Anatolische platteland woonde. Soms binnen enkele uren, soms binnen enkele dagen moesten de Armeniërs zich klaarmaken voor vertrek. Zo werden de Armeniërs van Erzurum begin juni 1915 gedeporteerd naar Der el-Zor. De Duitse consul van Erzurum, later een van de eerste nazi's, Erwin von Scheubner-Richter (1884-1923), rapporteerde hierover: 'In Anbetracht des Fehlens aller Transportmittel, Unsicherheit der Wege und bei der Vertreibung ausgeübter Grausamkeiten und Härte bedeutet diese Emigration eine absolute Ausrottung. ${ }^{{ }^{16}}$ De deportatie, midden in de zomerhitte, maakte hun dood in het harde Oost-Anatolische klimaat erg waarschijnlijk. Nog voordat het konvooi uit Erzurum de stad Erzincan had bereikt 
waren de gedeporteerden al ernstig verzwakt. Provincies als Trabzon, Sivas, Adana en Diyarbekir volgden snel. In juli 1915 was vrijwel de gehele Armeense bevolking onderweg naar de Syrische woestijn. Door middel van berichten via de telegraaf en assistentie van lokale functionarissen overzag Talaat de deportatie. Binnen anderhalf jaar waren een miljoen Ottomaanse Armeniërs vernietigd en de Ottomaans Armeense cultuur en beschaving fundamenteel en voorgoed ontwricht.

\section{Dynamiek van massaal geweld in de provincie}

In Diyarbekir ontwikkelde het genocidale proces zich anders dan in andere provincies. De provincie kreeg zijn reputatie wegens de enorme wreedheid waarmee de Armeniërs werden vervolgd, het feit dat veelal lokale massamoorden werden uitgevoerd in plaats van deportaties, en dat de categorie slachtoffers werd uitgebreid van Armeniërs naar christenen in het algemeen. Uiteindelijk week het verloop en de samenhang van de genocide in Diyarbekir significant af van het nationale niveau. Voordat we verdergaan, moet een saillant detail worden vermeld. Het is erg waarschijnlijk dat de lokale elite na de zomercrisis van 1914 de zittende gouverneur van Diyarbekir heeft laten verwijderen en een radicaal nationalistische gouverneur heeft laten aanstellen (Gaunt, 2006: 155). Die gouverneur was dr. Mehmed Reshid (1873-1919), een radicaal Jong-Turkse ideoloog die als gouverneur bekendstond om zijn rabiaat anti-Armeense ideeën. Hij zou de vervolging van Armeniërs uitbreiden tot een vervolging van christenen en zijn stempel drukken op de lokale variatie van de genocide in Diyarbekir (Kieser, 2002: 245-280). De macht van de lokale elites was door een zwakke centrale staat dus al zodanig sterk dat zelfs een belangrijke post als gouverneur door intensief lobbyen en intrigeren voor eigen belang kon worden gemanipuleerd. Zoals betoogd, was de concurrentie tussen de vooraanstaande families en hun machtsbasis in de stad een structureel kenmerk van de samenleving in Diyarbekir. Dit gegeven bestond dus al voor de Eerste Wereldoorlog. Beïnvloedde deze lokale machtsstructuur die genocide, en zo ja, hoe?

De massamoorden in Diyarbekir begonnen in mei 1915 en duurden tot eind 1916, toen de meerderheid van de Armeniërs en andere christenen goeddeels was uitgemoord. Talaat Pasja was in samenspraak met zijn directe kring van Jong-Turkse radicalen op 23 mei 1915 een uiterst complexe operatie begonnen, namelijk de deportatie van een gehele bevolkingsgroep. De dagelijkse uitvoering daarvan op regionaal niveau was een zaak van de gouverneurs. Het is mogelijk om sommige kernelementen van de gang van zaken te reconstrueren. Rafael de Nogales Mendez was een Venezolaanse officier in Duitse dienst die in het Ottomaanse leger diende. In de lente van 1915 was hij getuige van de massamoorden van 
Armeniërs aan de Russisch-Ottomaanse frontlinie. Hij bezocht Diyarbekir eind juni 1915 en kreeg de mogelijkheid om gouverneur Mehmed Reshid persoonlijk te spreken. Volgens Nogales had Reshid van Talaat een bevel gekregen dat slechts drie woorden inhield: 'Verbrand - Vernietig - Moord' (Yak - Vur - Öldür). Hoewel dit bevel nooit is teruggevonden in archieven (als het ooit al bestaan heeft), was dat zeker geen instructie voor Reshid om terughoudend te handelen. Ook zou Reshid toegegeven hebben dat hij slechts bevelen had uitgevoerd van Talaat, die hem gezegd zou hebben: 'J'assume la responsabilité morale et matérielle,' (Nogales, 2003: 125) Reshid interpreteerde dit bevel als een vrijbrief om te handelen zoals hem goeddunkte.

Eind mei was de Armeense elite al in hechtenis genomen. Toen Reshid het bevel van 23 mei ontving ging hij over tot een radicale actie. Op zondag 25 mei 1915 beval hij zijn milities om 807 notabelen te knevelen en door de stadspoorten richting de Tigris te begeleiden. Daar aangekomen moesten de mannen aan boord gaan van 17 grote vlotten onder het voorwendsel dat ze naar Mosul zouden worden gedeporteerd. De militie escorteerde de Armeense notabelen en voer ongeveer een uur stroomafwaarts, waar werd aangelegd. De notabelen werden bevolen geruststellende brieven naar huis te schrijven, waarna ze van hun kleding en bezittingen werden ontdaan, door de milities met zwaarden en dolken werden vermoord en in de rivier werden gegooid. De milities die het moorden uitvoerden waren voornamelijk gerekruteerd uit de Pirinççizâde-familie en stonden onder bevel van Aziz Feyzi. Zij hadden zich gretig gemeld voor de moordpartijen, wellicht niet alleen of primair omdat ze Armeniërs haatten, maar voornamelijk om Istanbul tevreden te stellen en hun concurrentiepositie met de andere families te versterken. De machthebbers waren inderdaad onder de indruk van de Pirinççizâde-mannen. Na de massamoord werden de daders uitgenodigd in het landhuis van de Pirinççizâdes en werd er feest gevierd. Ook werden de mannen uit de pot van geconfisceerde Armeense bezittingen beloond voor hun daden. Later werden ze zelfs door gouverneur Reshid uitgenodigd en gefeliciteerd met het 'succes'. Sommige mannen werden later door Reshid zelfs voorgedragen bij het ministerie van Binnenlandse Zaken als helden die in aanmerking zouden komen voor promoties en medailles. Twee maanden later werd Reshids verzoek ingewilligd en de daders ontvingen financiële bijdragen en onderscheidingen. ${ }^{17}$

Op 30 mei werd het ritueel herhaald met 674 Armeniërs, vijftig daders en dertien vlotten. Deze keer werden de slachtoffers beroofd van 6000 Turkse pond, kleding en juwelen. In Diyarbekir werden sommige bezittingen in de bazaar verkocht; gouverneur Reshid ontving het leeuwendeel van de geroofde bezittingen. ${ }^{18}$ Onder de vermoorde slachtoffers waren Armeense notabelen, zoals Onnik Kazazian, een groothandelaar 
uit Istanbul die toevallig in Diyarbekir op bezoek was. Andere slachtoffers waren de bekende bankiers Khatchadur Dikranian en Tirpandjian, rapporteerde M. Guy aan de Franse Ambassade in Istanbul op 24 juli 1915 (Beylerian, 1983: 48; Yeghiayan, 1951: 24-25; Krikorian, 1978: 24-25). Walter Holstein, de Duitse vice-consul van Mosul, berichtte een week later dat de vlotten leeg waren aangekomen en dat de Armeense konvooien 'compleet waren afgeslacht' (sämtlich abgeschlachtet). Hij had later hun lijken in de rivier zien drijven: 'seit einigen Tagen treiben Leichen und menschliche Glieder im Fluß hier vorbei. ${ }^{19}$

$\mathrm{Na}$ de vernietiging van de Armeense elite in Diyarbekir, breidde Reshid het geweld snel uit tot genocidale proporties. De mannelijke elite was vermoord en nu werden alle Diyarbekir-Armeniërs categorisch vervolgd. Op 1 juni 1915 beval hij zijn militie een razzia uit te voeren in de Armeense wijk van Diyarbekir. Meer dan duizend mensen werden geëvacueerd en door de stadspoorten naar het plateau van Diyarbekir geleid. Daar aangekomen werd luidkeels een proclamatie voorgelezen, waarin de Armeniërs een doodvonnis werd voorgelezen. De radeloze slachtoffers werden daarop uitgekleed en hun persoonlijke bezittingen werden hen afgenomen. De militie en lokale Koerdische dorpelingen sloegen daarna aan het moorden met vuurwapens, bijlen, zwaarden en dolken. Vrouwen werden verkracht en sommige werden als slaven verkocht. De lijken werden in putten en greppels gegooid of op het plateau aan de ontbinding overgelaten, 'the men on their stomachs, the women on their backs' (Noel, 1919: 10-11). Na de vernietiging van de Armeniërs in de stad Diyarbekir verordonneerde Talaat voor publieke consumptie het volgende deportatiebevel voor de Armeniërs op het platteland: 'Alle Armeniërs in de dorpen en provinciesteden zullen worden verwijderd naar Mosul, Urfa en Zor, zonder uitzonderingen. Vereiste maatregelen zullen worden genomen om hun levens en bezittingen tijdens de deportatie veilig te stellen. ${ }^{20}$ Maar tegelijkertijd beval hij zijn onderdanen om 'de plaatsnamen van Armeense dorpen en het achtergelaten bezit en het bewerkbare land te registreren'. ${ }^{21}$ Deze bevelen suggereren dat het nooit Talaats bedoeling is geweest om de Armeniërs veilig elders in het land te vestigen.

Na de vernietiging van de Armeense elite en stadsbevolking breidde Reshid de massamoord uit naar het platteland. De meer dan 130 Armeense dorpen in de provincie werden in de zomermaanden van 1915 systematisch uitgemoord, deels gedeporteerd of tot de islam bekeerd. In dit proces breidde Reshid de anti-Armeense vervolging uit tot een antichristelijke vervolging. De niet-Armeense christenbevolking bestond voornamelijk uit Syrisch-Orthodoxe en Chaldese christenen (Assyriërs/ Arameeërs), die in de steden Mardin en Midyat, in het gebied Tur Abdin ten zuidoosten van de provincie leefden. Hoewel hij van Talaat hier geen 
toestemming voor had gekregen, stuurde Reshid zijn milities richting Tur Abdin met de instructie om grootschalige moordpartijen aan te richten onder de Assyrische bevolking. In de zomer van 1915 vielen ook in die bevolkingsgroep tienduizenden slachtoffers. Voor zover de censuur er geen greep op kon krijgen, schreven getuigen uitgebreid over Reshids vernietigingscampagne. De Amerikaanse consul van Aleppo, Jesse Jackson, schreef op 28 juni dat de vervolging van christenen in Diyarbekir zodanig wreed en systematisch was dat gesproken kon worden over 'a reign of terror'. ${ }^{22}$

Zo ook de Duitse vice-consul Walter Holstein, die al eerder verontwaardigd had gerapporteerd over de massamoorden. In juni stuurde hij een telegram naar de Duitse ambassade en berichtte over de uitbreiding van de categorie slachtoffers.

Die Niedermetzelung der Armenier im Vilajet Diarbekir wird hier alltäglich bekannter und erzeugt eine wachsende Unruhe unter der hiesigen Bevölkerung die bei der unverständigen Gewissenlosigkeit und der Schwäche der hiesigen Regierung leicht unabsehbare Folgen herbeiführen kann. In den Bezirken Mardin [...] haben sich Zustände zu einer wahren Christenverfolgung ausgewachsen. Daran trägt zweifellos die Regierung die Schuld. ${ }^{23}$

Dit telegram was het eerste bericht dat de Jong-Turkse elite in Istanbul ontving over de lokale omgang met de vervolging van Armeniërs en heeft uiteindelijk spanning tussen Talaat en Reshid veroorzaakt. Talaat was ontstemd over Reshids brute en weinig subtiele methoden en vooral over de verbreding van de categorie slachtoffers. Toen Talaat door de Duitse ambassadeur werd verzocht te reageren suste hij de Duitsers, maar vermaande Reshid nog dezelfde dag.

Onlangs is gerapporteerd dat massamoorden zijn georganiseerd tegen de Armeniërs in de provincie en christenen zonder achting op godsdienst, en dat bijvoorbeeld mensen uit Diyarbekir en de bisschop van Mardin en 700 personen uit andere christelijke gemeenschappen 's nachts de stad zijn uitgeleid en als schapen zijn afgeslacht, en dat circa 2000 mensen tot nog toe zijn vermoord. Als dit niet onmiddellijk en onvoorwaardelijk ophoudt vrees ik dat de moslimbevolking van de aangrenzende provincies zullen opstaan en alle christenen zullen vermoorden. Het is absoluut onacceptabel dat de strafmaatregelen en het strafbeleid die tegen de Armeniërs worden gevoerd, wordt uitgebreid en ook andere christenen gaat omvatten, want dit zou een uiterst slechte indruk maken op de publieke opinie en daarom moeten dit soort 
incidenten die het leven van alle christenen bedreigen ogenblikkelijk beëindigd worden. ${ }^{24}$

In dit enigszins cryptische telegram liggen cruciale onthullingen verborgen. Talaat gebruikt hier niet alleen het eufemisme 'strafmaatregelen' om goed te keuren wat Reshid tot dan toe wél correct had gedaan: de vernietiging van de Armeniërs van Diyarbekir. Ook blijkt hieruit dat Reshid de norm had overschreden en zijn ongekende moordlust gênant werd voor Talaat. De genocide week op het lokale niveau te veel af van de nationale norm en dit bleek een probleem voor de hooggeplaatste daders.

Het verloop van de vervolgingen in Diyarbekir en de vorm die de genocide aannam in die provincie is moeilijk te begrijpen zonder de dynamiek tussen nationale en lokale actoren te belichten. Twee conclusies kunnen hier worden getrokken: de dispositie van de gouverneur bleek bepalend en lokale families konden wezenlijk bijdragen aan het vernietigingsproces. Het is waarschijnlijk dat vanwege Reshids fanatisme de genocide in Diyarbekir daarom die van elke andere Ottomaanse provincie overschreed in efficiëntie, reikwijdte, snelheid en wreedheid. Afgezien van deze factoren zijn ook relationele factoren belangrijk. De relatie tussen minister van Binnenlandse Zaken Talaat en gouverneur Reshid is van centraal belang in dit proces. In de derde week van mei 1915 had Talaat Reshid een mandaat verleend om de Armeense politieke partijen uit te schakelen. De fanatieke nationalist Reshid heeft dit bevel echter hoogstwaarschijnlijk opgevat als vrijbrief om de vernietiging van alle christenen in werking te zetten. Van alle gouverneurs die tijdens de Armeense genocide dienst deden is er geen enkele gouverneur berispt, behalve Reshid. De wreedheid en het fanatisme waarmee lokale milities in Diyarbekir tekeergingen tegen christenen is een tweede lokale afwijking van de genocide. De militie in Diyarbekir bestond uit de Pirinççizâde- en Müftüzâde-families. Zij moordden zonder genade, zonder onderscheid en zonder consequenties. De machtsbasis van en machtsstrijd tussen de lokale elites verleende een eigen vorm aan het vervolgingsproces.

\section{Conclusie: het risico van sterke bindingen}

Genocidespecialisten hebben gesuggereerd dat lokale dynamiek het verloop en de intensiteit van een genocidaal proces kunnen beïnvloeden. Lokale politieke of sociale elites kunnen vervolging versnellen en intensiveren, maar ook remmen, saboteren of zelfs tegenhouden. Politieke elites kunnen lokale machthebbers rekruteren voor hun eigen belangen, en omgekeerd kunnen lokale machthebbers politici manipuleren om hun eigen belangen veilig te stellen, zowel op korte als op lange termijn. 
Het potentieel van machtige, lokale clans om tientallen, soms honderden potentiële moordenaars te mobiliseren kan ertoe bijdragen dat zij tijdens een genocidale gebeurtenis door het machtscentrum worden bevoorrecht. Massamoord kan zich ontwikkelen uit deze wederzijdse afhankelijkheid en ongeschreven alliantie. Lokale elites zijn immers afhankelijk van het centrum om een machtsbasis op te bouwen, terwijl het centrum afhankelijk is van lokale elites om die massamoord uit te voeren. Deze dynamiek kan een mobilisatieproces opwekken waarin mannen deelnemen aan massamoord in ruil voor financiële en politieke gunsten van het regime. Haat en ideologie zijn cruciale verklaringen van mobilisatie, maar ook het opbouwen en vooral behouden van macht door lokale elites kan hieraan wezenlijk bijdragen.

De verdeling, uitoefening en dynamiek van macht is van cruciaal belang tijdens een genocide. Op lokaal niveau geeft deze macht gelegenheid om naar eigen inzicht vorm te geven aan de opdracht. De speelruimte om te handelen en de uitzichten op persoonlijk gewin kunnen in sommige gevallen aanzienlijk zijn en het is de aard van het regime (centralisatie of decentralisatie) die deze speelruimte bepaalt. De sociale almacht over leven en dood, lichaam en bezit produceert een ongekende machtsongelijkheid die de verschillende leiders uit de lokale elite de gelegenheid bood die genadeloos uit te buiten. Alle gewelddadige impulsen, seksuele wensen en collectieve haatfantasieën waaraan in vredestijd geen gehoor kan worden gegeven door juridische, politieke en morele beperkingen, kunnen straffeloos worden botgevierd.

De Ottomaanse provincie Diyarbekir heeft gefungeerd als voorbeeld om deze lokale dynamiek in het geval van de Armeense genocide te illustreren door de houding van de gouverneur en de concurrentie tussen clans te benadrukken. De concurrentie tussen deze stadselites was een belangrijke factor die aan de intensiteit van het geweld in Diyarbekir bijdroeg. Voor de oorlog waren de machtigste families in de stad al op hoog niveau verwikkeld in een strijd om politieke en economische invloed. Deze factor kon door de Jong-Turkse dictatuur vrij eenvoudig gemanipuleerd worden voor haar eigen doeleinden. Bovendien zette de schaarste veroorzaakt door de oorlog nog meer druk op deze concurrentie; een passieve opstelling was een regelrechte bedreiging voor het welzijn van de eigen clan.

Een voorname familie als de Pirinççizâde kwam uit deze concurrentiestrijd als overwinnaar tevoorschijn door genadelozer deel te nemen aan de campagne die de Jong-Turkse het meest dringend achtten, namelijk de moord op hun Armeense buren. Zo ontwikkelde de genocide zich voor de daders als een kans om verwantschapsrelaties te versterken. De belangrijkheid van deze sociale instituties legt in tijden van massaal geweld het risico van sterke bindingen bloot. Aziz Feyzi bewees zich tij- 
dens de genocide als een meedogenloze beul van Armeniërs en het is aannemelijk dat hijzelf meende slechts de belangen van zijn familie na te streven onder de zware omstandigheden van oorlog en schaarste. Vanuit dit subjectieve perspectief was de genocide niet zozeer een uiting van het kwaad, maar een afspiegeling van de deugd.

\section{Noten}

1 De auteur wil graag Ward Berenschot, Natalya Lazar, Dominik Schaller, Jacques Semelin en Abram de Swaan bedanken voor hun commentaar en hulp. Dit artikel is mede gebaseerd op een groot aantal Turkse boeken en artikelen. Om practische redenen zijn verwijzingen naar deze publikaties niet opgenomen. De lezer wordt verwezen naar mijn Young Turk Social Engineering: Mass Violence and the Nation State in Eastern Turkey, 1913-1950 (Proefschrift Universiteit van Amsterdam, 2009).

2 Politisches Archiv Auswärtiges Amt (hierna PAAA), Holstein aan Bethmann-Hollweg, 22 mei 1913.

3 PAAA, R14084, Mutius aan Bethmann Hollweg, 14 juni 1914.

4 Jacques Rhétoré, Les chrétiens aux bêtes! Souvenirs de la guerre sainte proclamée par les Turcs contre les chrétiens en 1915 (ongepubliceerd manuscript, Bibliothèque du Saulchoir), 59-60.

5 Başbakanlık Osmanlı Arşivi (Ottomaanse Archieven, Istanbul, hierna BOA), DH.KMS 2-2/5-7, document 7, gouverneur van Diyarbekir aan Ministerie van Binnenlandse Zaken, 26 maart 1913.

6 BOA, DH.SYS 23/4, document 2, gouverneur van Diyarbekir aan Ministerie van Binnenlandse Zaken, mei 1914.

7 BOA, DH.ŞFR 44/234, Emniyet-i Umûmiye Müdüriyeti (Ali Münif) aan Diyarbekir, 13 september 1914 .

8 BOA, DH.ŞFR 44/200, Talaat aan alle provinciën, 6 september 1914.

9 PAAA, R14085, Wangenheim aan Bethmann-Hollweg, 29 december 1914.

10 BOA, DH.ŞFR 48/166, Talaat aan de provincies Erzurum, Bitlis en Van, 26 december 1914 .

11 BOA, DH.ŞFR 51/15, Talaat aan de provincies Erzurum, Van en Diyarbekir, 14 maart 1915.

12 BOA, DH.ŞFR 53/91, 53/92 en 53/93, Talaat aan alle provincies, 23 mei 1915. Dit is het enige geval waarin de landelijke aard van de deportaties wordt vertegenwoordigd in één enkel bevel op het meest centrale niveau.

13 BOA, DH.ŞFR 53/85, Talaat aan Cemal Pasja, 23 mei 1915.

14 Public Record Office (Britse archieven, Londen, hierna PRO), FO 371/2488/51010, 28 mei 1915; United States National Archives (Amerikaanse archieven, Washington, hierna USNA) RG 59, 867.4016/67, 29 mei 1915.

15 BOA, MV 198/163, 30 mei 1915.

16 PAAA, Botschaft Konstantinopel, deel 169, Scheubner-Richter aan de ambassadeur, 4 juni 1915.

17 BOA, DH.EUM.MEM 67/31, 27 juli 1915. Deputies Aziz Feyzi and Zülfü Bey, and militia Major Şevki were decorated with honorary medals for their 'great achievements'. BOA, DH.KMS 43/10, 11 januari 1917. According to a British intelligence report, 'Deputy Feyzi was received by the Kaiser and decorated with the Iron Cross'. PRO, Foreign Office 371/4172/24597, no. 63490, folio 304. 
PAAA, R14087, directeur van de Deutsche Hülfsbund für christliches Liebeswerk im Orient (Frankfurt am Main) Friedrich Schuchardt aan het Auswärtige Amt, 21 August 1915, enclosure no.6; Lepsius, Todesgang [n.108], 75-76.

19 PAAA, Botschaft Konstantinopel 169, Holstein aan Wangenheim, 10 juni 1915.

20 BOA, DH.ŞFR 54/87, Talât aan de provincies Trabzon, Mamuret-ul Aziz, Sivas, Canik en Diyarbekir, 21 juni 1915.

21 BOA, DH.ŞFR 54/15, IAMM aan de provincies Adana, Haleb, Erzurum, Bitlis, Van en Diyarbekir, 14 juni 1915.

22 USNA, RG 59, 867.4016/92, Jackson aan Morgenthau, 28 juni 1915, in Ara Sarafian (ed.), United States Official Records on the Armenian Genocide 1915-1917 (London: Gomidas Institute, 2004), 84.

23 PAAA, Botschaft Konstantinopel 169, Holstein aan ambassade, 13 juni 1915.

24 BOA, DH.ŞFR 54/406, Talât aan Reşid, 12 juli 1915.

\section{Literatuur}

Ahmad, F. (1969). The Young Turks: The Committee of Union and Progress in Turkish Politics, 1908-1914. Oxford: Oxford University Press.

Ahmad, F. (1982). Unionist Relations with the Greek, Armenian, and Jewish Communities of the Ottoman Empire, 1908-1914. In B. Lewis en B. Braude, Christians and Jews in the Ottoman Empire: The Functioning of a Plural Society. New York: Holmes \& Meier Publishers.

Bloxham, D. (2002). The Beginning of the Armenian Catastrophe: Comparative and Contextual Considerations. In H.L. Kieser en D.J. Schaller, Der Völkermord an den Armeniern und die Shoah: The Armenian Genocide and the Shoah. Zürich: Chronos.

Bloxham, D. (2008). Genocide, the World Wars and the Unweaving of Europe. Edgware: Vallentine Mitchell.

Boeckh, K. (1996). Von den Balkankriegen zum Ersten Weltkrieg: Kleinstaatenpolitik und ethnische Selbstbestimmung auf dem Balkan. München: Oldenbourg.

Browning, C. (1983). The Final Solution in Serbia: the Semlin Judenlager. Yad Vashem Studies, 15, 73-85.

Davison, R.H. (1947). The Armenian Crisis, 1912-1914. The American Historical Review, 52, 481-505.

Erickson, E.J. (200o). Ordered to die: a history of the Ottoman army in the first World War. Westport: Greenwood Press.

Gaunt, D. (2006). Massacres, Resistance, Protectors: Muslim-Christian Relations in Eastern Anatolia During World War I. Piscataway: Gorgias Press.

Fraser, D. (1909). The Short Cut to India: The Record of a Journey along the Route of the Baghdad Railway. Edinburgh: William Blackwood and Sons.

Gawrych, G.W. (1986). The Culture and Politics of Violence in Turkish Society, 1903-1914. Middle Eastern Studies, 22, 303-330.

Gerlach, Chr. (1999). Kalkulierte Morde: die deutsche Wirtschafts- und Vernichtungspolitik in Weißrußland 1941 bis 1944. Hamburg: Hamburger Edition. 
Gruner, W. (2005). Local Initiatives, Central Coordination: German Municipal Administration and the Holocaust. In G.D. Feldman en W. Seibel, Networks of Nazi Persecution: Bureaucracy, Business, and the Organization of the Holocaust. (269-94). New York: Berghahn Books.

Holquist, P. (2002). Making War, Forging Revolution: Russia's Continuum of Crisis, 1914-1921. Cambridge, Mass.: Harvard University Press.

Kershaw, I. (2005). War and Political Violence in Twentieth-Century Europe. Contemporary European History, 14, 107-123.

Kévorkian, R. (1995). Receuil de témoignages sur l'extermination des amele tabouri ou bataillons de soldats-ouvriers Arméniens de l'armée Ottomane pendant la première guerre mondiale. Revue d'Histoire Arménienne Contemporaine, 1, 289-303.

Kieser, H.L. (2002). Dr. Mehmed Reshid (1873-1919): A Political Doctor. In H.L. Kieser en D.J. Schaller, Der Völkermord an den Armeniern und die Shoah: The Armenian Genocide and the Shoah. (245-280). Zürich: Chronos.

Kramer, A. (2007). Dynamic of Destruction: Culture and Mass Killing in the First World War. Oxford: Oxford University Press

Krikorian, M. (1978). Armenians in the Service of the Ottoman Empire. London: Routledge \& Kegan.

Lemkin, R. (1944). Axis Rule in Occupied Europe: Laws of Occupation - Analysis of Government - Proposals for Redress. Washington: Carnegie Endowment for International Peace.

Lepsius, J. (1919). Todesgang der Armenischen Volkes, Potsdam: Tempelverlag. Lieberman, B. ( 2006). Terrible Fate: Ethnic Cleansing in the Making of Modern Europe. Chicago: Dee.

Lohr, E. (2003). Nationalizing the Russian Empire: The Campaign against Enemy Aliens during World War I. Cambridge: Harvard University Press,

Lower, W. (2005). Nazi Empire-Building and the Holocaust in Ukraine. Chapel Hill: University of North Carolina Press,

Minassian, G.F. (1995). Les relations entre le Comité Union et Progrès et la Fédération Révolutionnaire Arménienne à la veille de la Premiere Guerre mondiale d'après les sources arméniennes. Revue d'histoire arménienne contemporaine, 1.

Minassian, A.T. (2000). Van 1915. In R.G. Hovannisian, Armenian Van/Vaspurakan (209-244). Costa Mesa: Mazda.

Morgenthau, H. (2000). Ambassador Morgenthau's Story. Ann Arbor: Gomidas.

Noel, E.W.C. (1919). Diary of Major E. Noel on Special Duty in Kurdistan. Basra. Nogales, R. de (2003 [1924]). Four Years Beneath the Crescent. London: Sterndale Classics.

Özoğlu, H. (2004). Kurdish Notables and the Ottoman State: Evolving Identities, Competing Loyalties, and Shifting Boundaries. Albany: State University of New York Press. 
Pohl, D. (1996). Nationalsozialistische Judenverfolgung in Ostgalizien 19411944: Organisation und Durchführung eines staatlichen Massenverbrechens. München: Oldenbourg.

Pomiankowski, J. (1928). Der Zusammenbruch des Ottomanischen Reiches: Erinnerungen an die Türkei aus der Zeit des Weltkrieges. Zürich: AmalthenaVerlag.

Prusin, A.V. (2005). Nationalizing a Borderland: War, Ethnicity, and Anti-Jewish Violence in East Galicia, 1914-1920. Tuscaloosa: University of Alabama Press.

Rees, E.A. (2003). The Changing Nature of Centre-Local Relations in the USSR, 1928-36. In E.A. Rees, Centre-Local Relations in the Stalinist State 1928-1941 (9-36). London: Palgrave Macmillan.

Rhétoré, J. (n.d.). Les chrétiens aux bêtes! Souvenirs de la guerre sainte proclamée par les Turcs contre les chrétiens en 1915. Ongepubliceerd manuscript, Bibliothèque du Saulchoir.

Reynolds, M.A. (2003). The Ottoman-Russian Struggle for Eastern Anatolia and the Caucasus, 1908-1918: Identity, Ideology and the Geopolitics of World Order. Ongepubliceerde dissertatie, Princeton University.

Strachan, H. (2001). The First World War: To Arms. Oxford: Oxford University Press.

Üngör, U.U. (2009). Young Turk Social Engineering: Mass Violence and the Nation State in Eastern Turkey, 1913-1950. Amsterdam: Proefschrift Universiteit van Amsterdam.

Vierbücher, H. (1985 [1930]). Armenien 1915: Die Abschlachtung eines Kulturvolkes durch die Türken. Bremen: Donat \& Temmen Verlag.

Werth, N. (2003). The Mechanism of a Mass Crime: The Great Terror in the Soviet Union, 1937-1938. In R. Gellately en B. Kiernan, The Specter of Genocide: Mass Murder in Historical Perspective (215-239). Cambridge: Cambridge University Press.

Yeghiayan, V. (1991). British Foreign Office Dossiers on Turkish War Criminals. Pasadena: AAIC. 


\title{
Identiteit, patronage en geweld in Oost-Congo
}

\author{
Koen Vlassenroot en Karen Büscher
}

\section{Inleiding}

Oorlog en conflict in Afrika worden tegenwoordig vaak geïnterpreteerd als gebeurtenissen die worden gestuurd door hebzucht. Rebellenbewegingen en milities zouden vooral strijd voeren om toegang te krijgen tot natuurlijke bronnen van rijkdom en niet langer worden gedreven door ideologische overwegingen. Begin jaren negentig werd een andere verklaring gegeven. Het einde van de Koude Oorlog had op het Afrikaanse continent een proces van staatsverval ingezet, dat in tientallen gevallen uitmondde in een spiraal van nooit gezien geweld. Voor sommigen duidden deze conflicten, en vooral het gebruik van ogenschijnlijk irrationele vormen van geweld, op een terugval naar oude, Afrikaanse tradities. Zo meende Kaplan na een reis door West-Afrika, in een al in 1994 geschreven invloedrijk artikel, dat de voornaamste deelnemers in Afrika's oorlogen gemarginaliseerde jongeren zijn die zich via een toevlucht tot geweld en het vormen van gewapende bendes willen wreken op de bestaande politieke en maatschappelijke ordening die verantwoordelijk wordt geacht voor hun gebrek aan kansen. Kaplan stelt het irrationeel en zinloos karakter van dit geweld aan de kaak; volgens hem zit de gruwelijke aard van dit geweld, dat vaak is gericht tegen de eigen bevolking, inherent vervat in de Afrikaanse cultuur.

Het scenario voor de toekomst is volgens Kaplan al minstens even grimmig als uitzichtloos: 'Now the threat is more elemental: it is nature unchecked. Africa's immediate future could be very bad' (Kaplan, 1994: 54). De wereld waarnaar we evolueren is er een van 'the withering away of central governments, the rise of tribal and regional domains, the unchecked spread of disease, and the growing pervasiveness of war' (Kaplan, 1994: 48). Deze pessimistische visie werd op heel wat kritiek onthaald. De vrees die de visie uitdrukt over de chaos waarin grote delen van 
Afrika begin jaren negentig dreigden te vervallen, werd omschreven als de 'these van de nieuwe Afrikaanse barbarij'. Toch bleef een visie waarbij geweld en conflict verklaard worden vanuit de Afrikaanse cultuur de volgende jaren domineren in de berichtgeving over Afrika's oorlogen. De Rwandese genocide en de burgeroorlogen in Sierra Leone, Noord-Oeganda en Liberia zijn maar enkele voorbeelden die moesten aantonen dat etniciteit de voornaamste motor van geweld en conflict was geworden en etnische tegenstellingen ideologische breuklijnen hadden vervangen.

Nergens was deze verklaring zo dominant als voor de situatie in Centraal-Afrika. De burgeroorlog in Burundi en de genocide in Rwanda werden verengd tot een strijd tussen Hutu's en Tutsi's. Hoewel Lemarchand er in het geval van Burundi al snel op wees dat 'in a time of crisis, Hutu and Tutsi emerge as the only relevant defining characteristics of group identities, rendering all other social roles to phenomena of marginal social significance' (Lemarchand, 1994: 14), werd toen in 1996 ook in Zaïre de strijd losbarstte, hetzelfde discours gehanteerd. Eind jaren tachtig werd al duidelijk dat het politieke systeem dat vanaf 1965 door president Mobutu was uitgebouwd en dat steunde op patronage, repressie en externe steun, in toenemende mate gebukt ging onder desintegratie en informalisering van politieke macht en economische controle. Het wegvallen van de externe steun eind jaren tachtig, een gevolg van het einde van de Koude Oorlog, zorgde voor een verder verval van het politieke regime. Toen in 1993 en 1994 honderdduizenden Burundese en Rwandese vluchtelingen zich vestigden in het oosten van Zaïre en vanuit de kampen een toenemende militaire macht uitbouwden gericht tegen de politieke machthebbers in Rwanda en Burundi maar ook tegen Zaïrese Tutsi-gemeenschappen, ontstond een regionale coalitie die vanaf 1996 strijd voerde tegen het Mobutu-regime.

Dit regime kwam in mei 1997 uiteindelijk ten val. Rebellenleider Laurent Kabila werd de nieuwe president, maar had al snel af te rekenen met een nieuwe rebellenbeweging die vanaf augustus 1998 grote delen van het oosten van het land onder controle kreeg, opnieuw met steun van buurlanden Rwanda en Oeganda. Deze rebellenbeweging raakte echter versplinterd en werd al snel bestreden door milities, vaak gesteund door een buurland of door het leger dat het westen van het land onder controle wist te houden. Deze strijd zou duren tot 2003, toen een definitief vredesakkoord werd getekend en een overgangsregering werd geïnstalleerd met deelname van de voornaamste rebellengroeperingen. Drie jaar later mondde dit uit in presidents- en parlementsverkiezingen, de eerste democratische in meer dan dertig jaar. Toch kwam hiermee geen einde aan het conflict in het oosten van het land. Gebrek aan vooruitgang in het vredesproces en onopgeloste lokale tegenstellingen verklaren waarom er tot vandaag de dag een groot aantal gewapende groepen opereert. 
We willen in dit hoofdstuk geen historisch overzicht bieden van het conflict in Democratische Republiek Congo, maar stilstaan bij de betekenis van etniciteit in processen van politieke mobilisatie, verzet en geweld. De Congolese oorlog wordt immers vaak gezien als een voortzetting van de Rwandese (etnische) genocide op Congolees grondgebied, of voorgesteld als een strijd tussen lokale etnische gemeenschappen op basis van breuklijnen die al tijdens de kolonisatie werden gevormd. In de oostelijke Kivu-provincies werd het conflict inderdaad vertaald als een strijd tussen lokale gemeenschappen en Rwandese migranten in Banyarwanda; in Ituri, waar tussen 1999 en 2003 een van de meest bloedige episodes van de Congolese oorlog werd geschreven, ontstond de indruk dat het ging om een hobbesiaanse oorlog tussen lokale etnische gemeenschappen, vaak met weinig geavanceerde wapens en met extreem brute uitingen van geweld die de gehele samenleving ontwrichtte.

Niettemin zullen we niet dieper ingaan op de veronderstelde relatie tussen etniciteit en geweld, maar deze relatie problematiseren. Ericksen stelt onomwonden dat 'ethnicity no longer seems to contribute to an explanation of the social world; it has itself become a phenomenon to be explained' (Ericksen, 1993). We willen illustreren hoe in het geval van Zaïre/Democratische Republiek Congo etniciteit een onderdeel werd van de dagelijkse interactie tussen staat en burgers en hoe referenties naar etniciteit vorm hebben gegeven aan strategieën van politici, militieleiders en handelaars. Eerder dan te vertrekken vanuit een perspectief van 'etniciteit als identiteit' benadert deze bijdrage etniciteit als 'praktijk' en als een variabele in sociale relaties die gekenmerkt wordt door een hoog potentieel van mobilisatie. Tevens zal aandacht worden besteed aan de rol van etniciteit in de Congolese burgeroorlog. Omdat we menen dat etniciteit niet zozeer de oorzaak van geweld is, maar gedrag 'informeert', zoals Crummey terecht meent: 'the real challenge is to see violence within its social setting, to appreciate its roots in social conflict, and to understand why and how people turn to it' (Crummey, 1996: 2).

Een dergelijk perspectief heeft als voordeel dat betekenis kan worden gegeven aan de algemene heropleving van het concept 'etniciteit'. Ingebed in een populair politiek discours heeft etniciteit, en de referentie naar etnische verbondenheid, in het geval van Congo betekenis gegeven aan de omgeving. Maar het werd tevens een belangrijke drijfveer voor het gebruik van geweld. We dienen dan ook vooral oog te hebben voor de manier waarop naar etnische identiteit via etnische narratieven wordt verwezen. Het zijn immers dergelijke narratieven die "channel political emotions so that they can fuel efforts to modify a balance of power; it transforms the perceptions of the past and the present; it changes the organisation of human groups and creates new ones; it alters cultures by emphasising certain traits and skewing their meaning and logic. The 
identity narrative brings forth a new interpretation of the world in order to modify it' (Martin, 1995: 13).

\section{De postkoloniale staat: patronage, uitsluiting en identiteit}

De geschiedenis van Zaïre kan een representatief voorbeeld van staatsimplosie en informalisering van politiek en economie worden genoemd, met etniciteit als een basisprincipe voor politieke en economische integratie en competitie. De staat die werd gecreëerd na de onafhankelijkheid in 1965 was in grote mate een afspiegeling van het koloniale regime, gebaseerd op een bureaucratisch-autoritaire machtsstructuur gericht op de totale controle van de economische productie, die vooral bestond uit mijnbouw en landbouw. Vooral na de staatsgreep die JosephDésire Mobutu in 1965 aan de macht bracht, werd onder het mom van ontwikkeling een beleid gevoerd dat was gericht op de exploitatie van de beschikbare economische hulpbronnen ten voordele van een kleine politieke elite die de staatsmacht bezat. Deze praktijk vervormde de staat en de nationale economie tot een raderwerk van patronagenetwerken onder controle van het politieke centrum, dat de gehele samenleving integreerde. Iedere Zaïrees was afhankelijk van een 'patroon' om toegang te krijgen tot bestuur, sociale voorzieningen en economie. De nieuwe politieke omgeving werd er een waarin 'any official decision affords an opportunity for gain, from a fiscal control to a technical verification, from the signature of a nomination form or a concessionary market to an industrial agreement or an import licence' (Bayart, 1993: 78).

Mobutu's strategie van politieke controle was vanaf het begin zeer duidelijk: 'verdeel de oppositie, selecteer dan de politiek en economisch zwaksten uit de groep van ontevreden politici en overlaad hen met fondsen'. De noodzakelijke bronnen hiertoe werden gegenereerd uit de exploitatie van de enorme reserves aan natuurlijke rijkdommen. Om de controle over deze economische basis te versterken werd tijdens de jaren zeventig een politiek van verregaande nationalisering uitgevoerd. Zo was de 'Zaïrisering-politiek' van 1973 er bijvoorbeeld op gericht om mijnbouwbedrijven en plantages op te eisen en te herverdelen onder diegenen die zich politiek loyaal opstelden. Uiteraard zorgde Mobutu ervoor dat deze leden van de heersende klasse niet de mogelijkheid kregen om een autonome machtsbasis op te bouwen en een uitdaging te vormen voor het politieke centrum.

Een beproefde strategie was hen regelmatig te ontdoen van hun privileges en te 'recycleren' in de oppositie, vanwaar ze opnieuw konden worden teruggeroepen. Uiteraard was dit politieke rotatiesysteem niet uniek; het is een zeer oude en beproefde politieke strategie om stabiliteit aan de heersende klasse te bieden, maar tegelijkertijd te zorgen voor 
een zekere vorm van onstabiliteit bij haar individuele leden. Een van de manieren om de vorming van een politieke tegenmacht te voorkomen was het terugvallen op individuen of groepen (voorbeelden zijn de Banyarwanda uit Noord-Kivu in de jaren zeventig, Kengo wa Dondo tijdens de laatste jaren van zijn bewind) die niet echt een basis onder de bevolking hadden en daarom nooit een werkelijke politieke uitdaging voor zijn positie konden vormen. Op die manier slaagde hij erin de nodige bureaucratische stabiliteit op te bouwen en zijn macht te consolideren. Aangezien het uitvoeren van de politieke macht door middel van patronagenetwerken het effect had van een zekere politieke integratie, werd de vorming van een functionerende oppositie praktisch onmogelijk. En wanneer een dergelijke tegenmacht toch de kop zou opsteken, kon Mobutu terugvallen op een uitgebreid netwerk van veiligheidsdiensten, waarvan de belangrijkste de Division Spéciale Présidentielle (DSP) was. De Zaïrese natie werd voorgesteld als één grote familie, met Mobutu aan het hoofd. En als de vader van de natie had Mobutu steeds het recht om te straffen wanneer hij dat nodig vond.

De bevoorrechte toegang tot economische hulpbronnen gaf de heersende klasse de kans haar dominante positie te versterken, aangezien de staat het ultieme instrument voor zelfverrijking was. Voor de rest van de bevolking leverde deze patronagepolitiek vooral een groeiende politieke, sociale en economische uitsluiting op, ondanks het feit dat patronagenetwerken de fundamentele schakel werden tussen staat en samenleving. De toegang tot politieke participatie werd de meeste Zaïrezen ontzegd, en hun economisch succes was afhankelijk van hun integratie in patronagenetwerken. Omdat deze netwerken in de eerste plaats waren gebaseerd op etnische solidariteit, resulteerde deze politiek in een institutionalisering van etniciteit als het organiserend principe binnen de samenleving, politiek en economie. De grote uitdaging bleef om de bevolking op het platteland, die in de eerste jaren van de onafhankelijkheid de belangrijkste producent was, de landbouw zorgde immers voor een aanzienlijk deel van de nationale inkomsten, te integreren in de postkoloniale, patrimoniale staat. De beste manier hiertoe was de traditionele leiders een plaats te geven binnen de bestaande politieke machtsstructuren en staatsbestuur. De hieruit ontstane allianties lieten lokale elites toe het agrarische overschot af te romen en de handel in marktgewassen onder hun controle te brengen.

De postkoloniale ontwikkeling in Oost-Zaïre vormt een goed voorbeeld van deze verdere institutionalisering van etniciteit als gevolg van de integratie van traditionele leiders in de heersende patronagenetwerken. Tijdens de kolonisatie werden etnische gemeenschappen duidelijker gedefinieerd en geïntegreerd in het bestuur. Zo werd het traditionele bestuur een direct onderdeel van het staatsapparaat. Na de kolonisatie 
werd deze strategie voortgezet en traditionele chefs werden de lokale vertegenwoordigers van de staat. Op verschillende manieren institutionaliseerde de integratie van etnisch gedefinieerde regio's in de administratieve organisatie van de staat etniciteit als organisatiecriterium. Zoals Mugangu opmerkt 'en fait, par la maîtrise du territoire ethnique, non seulement, les autorités coutumières deveinnent partenaires incontournables au processus du territorialisation de l'Etat, mais en plus elles peuvent reproduire, dans le contexte nouveau de cet Etat moderne, des rapports clientelists de type traditionel avec les élites et les paysans, lesquels, par le biais du foncier, reproduisent à leur tour entre eux le même rapport' (Mugangu, 1998: 8). De inzet van deze nieuwe lokale machtsnetwerken was de controle over land, sociale controle en de accumulatie van private rijkdom.

Een illustratie van dit proces van territorialisering van de staat en patrimonialisering van economische bronnen biedt de organisatie van de toegang tot en het gebruik van land. Oorspronkelijk weerspiegelde het economisch gebruik van land de lokale sociale organisatie van de etnische gemeenschap en bood het de materiële basis voor etnisch gevoel van er bij te horen, dat in meer algemene termen wordt beschreven door Lonsdale als moral ethnicity (Lonsdale, 1995). De reorganisatie van het landbeheer en -gebruik door de opkomst van nieuwe deelnemers via de politiek (patronage) en de markten (commercialisering van landbouw) tastte tijdens de jaren zeventig deze sociale organisatie aan. Omdat landbouw een bron van verrijking werd en de originele traditionele leiders werden geïntegreerd in nieuwe patronagenetwerken na de introductie van de landwet van 1973, werd de lokale sociale cohesie grondig aangetast. Lonsdale beschrijft het gehele effect van de introductie van de markt in het traditionele systeem van economische en sociale organisatie als afhankelijk van de mate waarin de prekapitalistische hiërarchieën ontvankelijk waren tegenover hun 'gasten', 'les visiteurs $d u$ soir' zoals Bayart hen noemt, en in hoeverre de kapitalistische 'bezoeker' zich gedraagt als een mogelijke saboteur van de lokale morele economie (Lonsdale, 1995). In het geval van de Kivu-provincies bleven de traditionele leiders de bevoorrechte bemiddelaars voor de verdeling van land aan lokale boeren en de verkoop aan nieuwe entrepreneurs en politieke elites. Voor de bevolking was het gevolg desastreus. Landcontrole door nieuwe coalities van traditionele leiders, ondernemers en politici leidde vooral in de dichtstbevolkte regio's tot de verschuiving van het gebruik van land. Door grootschalige landonteigening ontstond een arbeidssurplus in de landbouw en werden grote delen van de bevolking landloos. Het gevolg was een verhoogde competitie om land en om verscherping van sociale en economische breuklijnen op etnische basis. Dat benadeelde vooral de allochtone gemeenschappen, die werden beschouwd als 
niet-inheemse burgers en daarom geen toegang tot land konden opeisen via traditionele autoriteitsstructuren waartoe ze als allochtone gemeenschappen geen recht hadden.

\section{De grenzen van patrimoniaal bestuur}

Het einde van de jaren tachtig betekende voor Mobutu's regime een keerpunt. De directe link tussen politieke en economische macht zorgde voor een verhoogde competitie die in toenemende mate een etnische invulling kreeg. Ook in het geval van Zaïre werd etniciteit een soort ideologische basis voor sociale en politieke mobilisatie, vooral toen de grenzen van Mobutu's politieke systeem duidelijk werden. De belangrijkste paradox van patrimoniaal bestuur bleek in het geval van Zaïre dat 'the practice of accumulation of wealth through control over political power extended ethnically-based patronage networks, while the established pattern of hegemony became one of fragmentation and unbalanced accumulation' (Van Hoyweghen en Vlassenroot, 2000: 104-105). Mobutu's patronagepolitiek bleek zelfvernietigend en bracht niet alleen de Zaïrese economie ten val, maar raakte hierdoor eveneens aan de basis van de politieke elite zelf. Patrimoniale controle over staatsmiddelen was in strijd met de economische efficiëntie en de schade aan de economische productiviteit was niet te overzien.

Echt problematisch werd het pas toen als gevolg van het einde van de Koude Oorlog ook een einde kwam aan onvoorwaardelijke externe steun. Economische achteruitgang en verminderde externe hulp tastten de herverdelende capaciteit van het politieke centrum verder aan en werkten de vorming van gedecentraliseerde patronagenetwerken, die erin slaagden inkomsten te genereren uit de controle over clandestiene handelsnetwerken, in de hand. Dit gaf aanleiding tot de ontwikkeling van lokale strongmen die erin slaagden steeds meer autonoom van het politieke centrum te opereren. De generaals Nzimbi en Baramato bijvoorbeeld, die lange tijd tot Mobutu's belangrijkste bondgenoten behoorden, slaagden er vanaf eind jaren tachtig in om gedecentraliseerde patronagenetwerken uit te bouwen en werden autonome actoren in de controle over clandestiene handelsactiviteiten in onder meer de diamantsector. Door het wegvallen van de noodzakelijke economische basis verbrokkelde Mobutu's politieke systeem en ontstonden lokale machtscentra die via controle over informele handelsstromen steeds moeilijker in bedwang te houden waren. De Zaïrese president werd verplicht op zoek te gaan naar nieuwe oplossingen en innovatieve overlevingsstrategieën, waarbij de verwijzing naar etniciteit enkele belangrijke mogelijkheden bood.

De beste manier om te voorkomen dat uit deze verbrokkeling van 
politieke en economische macht een belangrijke oppositiekracht zou groeien, was het aanwakkeren van competitie. Hiervoor werden twee strategieën ontwikkeld. In april 1990 kondigde Mobutu een democratiseringsproces aan. Tegelijkertijd introduceerde hij enkele maatregelen die etnische competitie moesten aanwakkeren. Zo was er de invoering van het principe van de géopolitique, dat onder meer inhield dat nationale instellingen voortaan zouden worden samengesteld op basis van regionale quota en dat belangrijke lokale administratieve functies enkel konden worden ingevuld door individuen die afkomstig waren uit de betrokken regio. Daarvoor was het verboden om in de eigen regio belangrijke politiek-bestuurlijke functies op te nemen met als voornaamste reden de vorming van lokale machtsbases te voorkomen. De betekenis van Mobutu's nieuwe beleid werd snel duidelijk. Het wakkerde in een situatie van toenemende schaarste lokale competitie aan. In 1992 werden door een lokaal netwerk van onder meer politici en jongerenmilities in de Shabaprovincie pogroms georganiseerd tegen de Baluba die afkomstig waren uit de Kasai-provincies. De strategie werd deels ingegeven door het streven naar het breken van de machtsbasis van de UDPS, de voornaamste oppositiepartij die vooral rekruteerde en populaire steun genoot in Kasai.

In de Kivu-provincies leidde dat tot een intense competitie tussen lokale politieke elites. Mobutu's verdeel-en-heersbeleid, gebaseerd op etnische criteria, was een doeltreffende strategie om te verhinderen dat de lokale civiele samenleving een politieke stem zou krijgen. Die civiele samenleving, in werkelijkheid een platform van duizenden verschillende organisaties, kende in dit deel van het land een enorme expansie en deed zich voor als een forum voor dialoog en een leidinggevende beweging binnen het proces van democratisering. Ze slaagde er echter nooit in een brede sociale beweging te worden die zich kon mobiliseren tegen de centrale politieke macht, omdat netwerken van verzet en van dominantie zeer sterk onderling verbonden bleven en nooit boven lokale etnische loyaliteiten uitstegen. Zo vormden in Oost-Zaïre zogenaamde 'mutualiteiten' het ideale middel voor mobilisatie.

Zowel in Noord- als in Zuid-Kivu waren deze mutualiteiten tot het begin van de jaren negentig de enige toegelaten organisatievorm naast Mobutu's eenheidspartij. Ze ontstonden vooral in stedelijke milieus en verenigden in de meeste gevallen leden van dezelfde etnische gemeenschap. Hoewel deze basisorganisaties in oorsprong een aantal culturele en sociale functies vervulden en bijstand verleenden aan hun leden, evolueerden ze tijdens het democratiseringsproces tot belangrijke politiekeconomische kanalen voor mobilisatie. Na de aankondiging van het democratiseringsproces in april 1990 zochten lokale politici hun toevlucht tot deze mutualiteiten om zich van een populaire basis te voor- 
zien. De gedeelde sociale solidariteit tussen haar leden werd versterkt en vertaald in een zeker wantrouwen tegenover andere etnische gemeenschappen. Deze mutualiteiten vormden het ideale instrument voor de vorming van allianties tussen lokale politici en andere leden van dezelfde etnische identiteit. Zij opereerden als alternatieven voor politieke partijen en evolueerden tot voorname instrumenten van etnische mobilisatie, gestuurd door ambitieuze lokale politici.

Maar tegelijk waren deze organisaties van vitaal belang voor de controle over nieuwe, informele organisatievormen binnen de Zaïrese samenleving. Als gevolg van de verschrompeling van de formele economie en de staat hadden zich een bijzonder sterke informele economische sector en een autonoom organisatieleven ontwikkeld, met als voornaamste doelstellingen in het economisch overleven te voorzien en te ontsnappen aan de willekeurige terreur en uitbuiting door de staat. Zoals MacGaffey dit fenomeen omschreef, 'by their actions, people are contesting what is legitimate. By refusing to comply with regulations and restrictions, they confront and resist, in a nonviolent manner, a predatory state and the class that controls it (MacGaffey, 1987: 172). Een 'zorg-voor-jezelf-houding (article 15) van het mobutisme diende bovendien als een soort sociaal pact tussen de staat en de maatschappij, omdat het de staat toeliet zich terug te trekken uit het openbare leven en zijn functies, terwijl de maatschappij de mogelijkheid bezat zich op de grens van de wettelijkheid te bewegen om in haar eigen levensonderhoud te voorzien. Als gevolg van het uitbuitende karakter van de Zaïrese staat en de steeds groter wordende economische ontmanteling die hierdoor werd veroorzaakt, werd de bevolking steeds meer gedwongen tot strategieën van zelfredzaamheid en bescherming buiten de officiële economie om, door terug te vallen op informele economische netwerken, vaak met etnische loyaliteit als bindmiddel. Vooral in de Zaïrese grensgebieden zoals de Kivu-provincies verklaren deze ontwikkelingen de voortdurende uitbreiding van informele en frauduleuze handelsactiviteiten, die al op het einde van de jaren zeventig zo alomvattend werden dat ze niet alleen verantwoordelijk waren voor het ondermijnen van het staatsgezag, maar ook belangrijke veranderingen met zich meebrachten in de sociale structuur waarop deze was gebaseerd.

Vooral in Oost-Zaïre ontstond uit deze informele sector eind jaren tachtig een belangrijke oppositiekracht. Nieuwe, onafhankelijke en ontwikkelingsgerichte organisaties verenigden zich in een zeer dynamische civiele samenleving die vanaf de start van het democratiseringsproces een toenemende politieke rol opeiste. Door pogingen van het politieke centrum en de lokale politieke elite om enige greep te krijgen evolueerde deze informele sector van een brede, sociale coalitie tegen Mobutu's dictatoriaal regime tot een vorm van primordiale solidariteit gericht 
op de belangen van de particuliere etnische gemeenschap. Mobutu was er immers tijdens de democratisering in geslaagd de macht van deze brede sociale beweging te breken door het aanwakkeren van etnische verschillen. In Zuid-Kivu viel de civiele samenleving uit elkaar na spanningen tussen de twee voornaamste etnische groepen; de onmiddellijke aanleiding was de strijd om het voorzitterschap over het bureau van de civiele samenleving, die snel een etnisch karakter kreeg en gekoppeld werd aan de competitie tussen de dominante etnische gemeenschappen voor politieke macht over de provincie. In Noord-Kivu raakten mutualiteiten en andere organisaties rechtstreeks betrokken bij processen van etnische mobilisatie tegen de Banyarwanda, die werden gezien als de voornaamste bedreiging voor de politieke en economische positie van de autochtone gemeenschappen. Toen in 1993 een conflict ontstond tussen autochtone en Banyarwanda-gemeenschappen rond de toegang tot land, werd een nieuw proces van etnische mobilisatie in gang gezet waarbij mutualiteiten een voorname rol speelden.

Voor het eerst was echter ook sprake van de vorming van etnische milities, lokale zelfverdedigingsgroepen die werden opgericht door traditionele leiders en hun politieke bondgenoten. Hoewel dit conflict na enkele maanden kon worden opgelost, was het een indicatie voor de ernst van de crisis. Niet alleen vonden enkele duizenden mensen de dood en werden tienduizenden boeren ontheemd. De staat was in ernstig verval geraakt, de politieke macht was totaal gedesintegreerd en de politieke strijd verliep exclusief via etnische breuklijnen. Steeds meer betrokkenen zochten toevlucht tot geweld als legitiem middel van controle of verzet. Etniciteit begon als criterium voor politieke participatie steeds meer te domineren, terwijl ook patronage steeds meer een etnische invulling kreeg.

\section{Etniciteit als rechtvaardiging van geweld}

Toch zou het politieke systeem van Mobutu niet onmiddellijk volledig in elkaar storten. Hoewel in Oost-Zaïre alle interne voorwaarden voor de uitbarsting van een grootschalig conflict al geruime tijd aanwezig waren, veranderde de situatie dramatisch na de aankomst in 1993 en 1994 van honderdduizenden Hutu-vluchtelingen uit Burundi en Rwanda. Deze vluchtelingenstroom verscherpte bestaande tegenstellingen tussen Zaïrese bevolkingsgroepen. De aanwezigheid van gewapende milities binnen de vluchtelingenkampen en een sterk gepolitiseerd etnisch discours van vooraanstaande vluchtelingenleiders moedigde ook de verdere verspreiding van gewapende groepen binnen de Zaïrese samenleving aan. Het is zeer waarschijnlijk dat de vluchtelingencrisis nooit zou zijn geëscaleerd tot een dergelijk grootschalig geweld, indien het Zaïrese 
regime niet in totaal verval verkeerde en niet had getracht zichzelf te herstellen door middel van de uitbuiting van deze vluchtelingen.

Gezien de bijzondere positie van de Zaïrese staat had de massale instroom van meer dan één miljoen vluchtelingen - gewapend en bevoorraad van buitenaf - diepgaande gevolgen voor de lokale bevolking. Ze creëerde de rechtvaardiging en de basis voor verder geweld door de Rwandese tegenstelling tussen Hutu's en Tutsi's centraal te stellen in de lokale strijd. Lokale tegenstellingen tussen autochtonen en Banyarwanda-gemeenschappen in Noord-Kivu werden vervangen door een nieuwe coalitie van lokale Hutu-Banyarwanda en autochtone milities, die het concept van 'Hutu-land' creëerden en hun strijd richtten tegen de lokale Tutsi: 'the massive arrival of anti-Tutsi refugees, combined with the local anti-Tutsi sentiment fermented by local authorities and the Zairian government, largely contributed to the escalation of the conflict. The ex-FAR and the Interahamwe established de facto minirepublics over more than one million Hutu refugees and the local people with the full understanding of the Zairian government and the Forces Armées Zairoises' (Gnamo, 1999: 327).

Maar Rwandese milities voerden ook, vaak in samenwerking met het Zaïrese leger, roofovervallen uit tegen de bevolking. Ter verdediging van de eigen gemeenschap moedigden traditionele leiders de vorming van gewapende zelfverdedigingsgroepen aan. Lokale politici, die nog steeds strijd voerden met als doel zich te positioneren binnen het democratiseringsproces, ontdekten de kracht van deze gewapende groepen. In Uvira (Zuid-Kivu) rekruteerde de voorzitter van het Zaïrese parlement, Anzuluni Bembe, jongeren binnen de eigen Bembe-gemeenschap om te strijden tegen de Banyamulenge, Zaïrese Tutsi's van Rwandese afkomst die eind negentiende eeuw emigreerden naar Congo en die werden gezien als de oorzaak van alle kwaad. Bembe vormde een coalitie met de lokale districtscommissaris en de provinciale vice-gouverneur met als doel de Banyamulenge uit te sluiten van het democratiseringsproces, maar ook om de gehele gemeenschap sociaal en economisch te marginaliseren. In de Plaine de la Ruzizi (Zuid-Kivu), waar een historische competitie bestond tussen traditionele Bafulero- en Barundi-autoriteiten voor de controle over de verdeling van land, zagen de Bafulero hun kans om de Barundi, die steeds werden erkend als de legitieme autoriteiten, hun macht te ontnemen. In andere delen van de Kivu-provincies was de controle over de toegang tot land het excuus voor een strijd tussen lokale gemeenschappen over het recht op toegang tot het land. Deze conflicten konden stuk voor stuk worden omschreven als conflicten rond 'autochtonie'.

Vanaf deze periode was geweld definitief in de lokale samenleving geïntroduceerd als strategie van controle en verzet. Toch kwam de directe aanleiding voor het begin van de eerste Zaïrese oorlog van buitenaf. 
Toen duidelijk werd dat een coalitie tussen Rwandese en Burundese Hutu-groepen en Zaïrese elites vanuit de vluchtelingenkampen ook de oostelijke buurlanden Oeganda, Rwanda en Burundi dreigden te destabiliseren, werd een verdere escalatie van een al langer sluimerend conflict onafwendbaar. Toen de campagne in Zuid-Kivu tegen de Banyamulenge-gemeenschap in de zomer van 1996 verder uit de hand liep, was dit het ideale excuus voor de buurlanden om ook een eind te maken aan de militaire dreiging die uitging van de vluchtelingenkampen. Er werd een rebellenbeweging gevormd (de AFDL) die vooral rekruteerde binnen lokale allochtone gemeenschappen (Banyarwanda en Banyamulenge) en directe militaire steun kreeg van Rwanda, Oeganda en Burundi, maar ook kon rekenen op hulp van onder meer Zimbabwe en Angola. Een totaal verzwakt Mobutu-regime bood nauwelijks enige weerstand en zeven maanden later kwam Laurent-Désire Kabila, de leider van de AFDL, aan de macht. Wat echter het sleutelelement was geweest van dit militaire succes, bleek voor Kabila's beweging een van de meest belangrijke obstakels voor de bestendiging van haar interne politieke macht. Wilde de nieuwe president enige interne legitimiteit opbouwen, dan diende hij zich los te weken van zijn militaire bondgenoten.

Vooral de steun van het Rwandese regime, dat werd gezien als een Tutsi-regime, was moeilijk verteerbaar voor grote delen van de Congolese bevolking (na Kabila's machtsovername werd de naam Zaïre vervangen door Democratische Republiek Congo). Het dilemma van de nieuwe Congolese autoriteiten werd de raison d'être van een nieuwe rebellenbeweging. Toen in juli 1998 de Rwandese en Oegandese militairen twee weken de tijd kregen om het Congolese grondgebied te verlaten, werd een nieuwe oorlog voorbereid. Begin augustus werd de Rassemblement Congolais pour la Démocratie (RCD) opgericht, opnieuw met steun van de buurlanden Rwanda en Oeganda en deze keer met als doel een einde te maken aan het Kabila-regime. Wat verwacht werd een herhaling van de eerste oorlog te worden, namelijk een korte, succesvolle militaire strijd, zette echter een nieuw proces van militaire fragmentering in. Al snel viel de RCD-rebellenbeweging uit elkaar en ontstonden rivaliserende fracties als gevolg van spanningen tussen de Oegandese en Rwandese steunpilaren van de beweging. Tegelijkertijd werd de RCD in toenemende mate uitgedaagd door andere gewapende actoren, zoals lokale selfdefence groups, rurale milities en buitenlandse gewapende groepen.

Deze extreme groei van gewapende groepen veranderde vanaf 1998 het oosten van de Democratische Republiek Congo in een lappendeken van verschillende controlestructuren. Toen deze nieuwe gelokaliseerde machtsconfiguraties in staat bleken om de steun van buurlanden, transnationale economische spelers of georganiseerde misdaadnetwerken aan te trekken, werden ze hoe langer hoe meer gezien als nieuwe 
exploitatiestructuren, gericht op het maximaliseren van de winst uit de lucratieve handel in natuurlijke rijkdommen ten voordele van externe actoren. Toch viel ook hier de centrale rol van etnische solidariteit op. De meeste gewapende groepen steunden op een particuliere etnische basis en consolideerden verder lokale etnische breuklijnen. Meer van dat zelfs, in een aantal gevallen werden deze gewapende structuren onderdeel van een bredere strategie en zoektocht naar gelokaliseerde legitimiteit op basis van etnische loyaliteit. Terwijl vóór de oorlog mutualiteiten de belangrijkste structuren vormden voor de bescherming van de eigen etnische gemeenschap en onder directe controle stonden van belangrijke handelaars en politici, verdwenen deze groepen meer en meer uit het beeld en werden ze nu vervangen door nieuwe coalities rond gewapende groepen die erin slaagden autonoom te opereren.

\section{De behoefte aan bescherming en de groei van etnische milities}

Een groot aantal van deze gewapende groepen werd tijdens de Congolese oorlogen opgericht door traditionele leiders en lokale jongeren vanuit een directe behoefte aan bescherming. Zoals in andere conflictsituaties werden, naarmate het niveau van geweld tijdens de Congolese oorlog steeds extremere vormen aannam en ook een toenemend aantal burgerslachtoffers viel, veiligheid en bescherming belangrijke onderwerpen van onderhandeling tussen rebellen en lokale sociale groepen. Zoals hierboven werd geillustreerd, begonnen al in het begin van de jaren negentig, toen door president Mobutu een democratiseringsproces werd aangekondigd dat gepaard ging met regelmatige uitbarstingen van politiek geweld, rurale milities te operen in het oosten van Zaïre. Meestal werden deze gewapende groepen opgericht met als doel de lokale bevolking te beschermen, hoewel ze vaak ook de directe belangen van plaatselijke politici dienden, vaak met de medeplichtigheid van traditionele leiders. Naargelang de plaatselijke bevolking verdeeld raakte door politieke concurrentie en het etnisch discours in sleutelkwesties als de toekenning van grond, evolueerden deze gewapende groepen tot verdedigers van de eigen etnische gemeenschap.

Na de start van de eerste Congolese oorlog in oktober 1996, werden diezelfde gewapende groepen onderdeel van een veel bredere politiekmilitaire strijd. Plaatselijke etnische gemeenschappen moesten niet langer beschermd worden tegen hun directe buren, maar ook tegen de buitenlandse troepen en hun Congolese bondgenoten die grote delen van het Congolese territorium bezetten. Dit verklaart waarom vanaf 1996 een enorm aantal gewapende groepen in de Kivu-provincies en Ituri werden opgericht, vaak als gevolg van spontane reacties met als voornaam- 
ste doel de eigen etnische gemeenschap te verdedigen, soms ook als gevolg van private ambities van lokale personen. In sommige gevallen ging het echter verder en werden door militieleiders pogingen ondernomen om een politiek-militair alternatief te bieden voor de staat, meestal door herstel van bestaande staatsstructuren.

Toen eenmaal de controle over een bepaald gebied was veiliggesteld, werden lokale traditionele leiders geraadpleegd, staatsvertegenwoordigers vervangen door plaatselijke bestuurders die loyaal waren ten opzichte van de gewapende beweging, mechanismen geïntroduceerd die het gebruik van geweld dienden te regelen, afspraken gemaakt over economische transacties en de lokale bevolking gemobiliseerd, meestal door een discours van collectieve bescherming. Een voorbeeld van deze dynamiek is de Mayi-Mayi-militie die werd geleid door generaal Padiri Bulenda en opereerde in grote delen van Zuid- en Noord-Kivu. Deze gewapende groep, die voor het eerst actief was tijdens de eerste Congolese oorlog, maar vooral na 1998 een prominente rol speelde, presenteerde zichzelf als een politiek-militaire beweging die het ineengestorte institutionele raamwerk van de Zaïrese staat wilde herstellen en de autochtone bevolking wilde beschermen tegen externe bedreigingen. Concreet beschouwd installeerde deze beweging een gemilitariseerd autoritair regime dat soevereine autoriteit claimde in de door hen gecontroleerde gebieden (Morvan, 2005). Terwijl verschillende plaatselijke comités, zoals het Comité de Sécurité Civile en het Comité des Mamans Sociales, de plaatselijke bevolking moesten mobiliseren en de legitimiteit van de rebellen bevestigden, werden officiële instituties nieuw leven ingeblazen en de traditionele autoriteiten geïntegreerd in hun bestuursstructuren. De strenge controle, via ideologische seminaries, over de burgerlijke ambtenaren en bevolking, en de introductie van repressieve justitiemechanismen, bevestigde dat de beweging 'relied heavily on disciplinary and sovereign techniques of government' (Hoffman, 2007: 102).

Toch is enige voorzichtigheid geboden bij de beoordeling van het beleid van Padiri's beweging. Zelfs al bevorderde de beweging volledige vrijheid voor de autochtone bevolking, ze werd voortdurend gecontroleerd en in haar bewegingsvrijheid beperkt. Het heffen van belastingen door de rebellen op de lokale economische activiteiten was bedoeld om het bureaucratisch apparaat van de beweging te financieren, maar leidden tot een militarisering van de ontginnings- en handelsactiviteiten en de verdere marginalisering van de vooroorlogse administratieve structuren. Hoewel nauwelijks kan worden ontkend dat de Mayi-Mayi onder leiding van Padiri een zekere bescherming boden, dient toch te worden vastgesteld dat wat werd voorgesteld als een etnisch ingebed alternatief voor de staat en een poging om een eind te maken aan de marginale economische en sociale positie van de lokale bevolking, stap voor stap 
evolueerde naar een beweging die repressie verwarde met bescherming en uitbuiting met ontwikkeling.

Een gelijke ontwikkeling kan worden waargenomen in Ituri (NoordOost-Congo), waar tijdens de oorlog verscheidene gewapende groepen beweerden voornamelijk te opereren ter bescherming van de plaatselijke bevolking, maar in werkelijkheid zich beperkten tot de bescherming van de eigen etnische achterban, en tegelijkertijd hebben getracht om hun greep op de lokale bevolking en economische bronnen te consolideren via alternatieve controlemechanismen. Oorspronkelijk kon het conflict in Ituri worden gezien als een episode van een langere strijd tussen lokale gemeenschappen voor de controle over land. Een gebrek aan een duidelijk legaal kader rond landverdeling, de historische dominantie van een van de gemeenschappen over de toegang tot land en het gebruik van land als bron binnen patronagenetwerken, hebben regelmatig geleid tot spanningen en conflict tussen lokale elites en gemeenschappen (met de Hema/Gegere en Lendu als hoofdrolspelers) die echter zelden een hoge graad van geweld zouden bereiken.

Tijdens de Congolese oorlog probeerden lokale elites hun positie te versterken en zetten zij hun eisen voor land kracht bij door het rekruteren van lokale jongeren. Externe inmenging en het kader en de mogelijkheden van de Congolese oorlog hebben deze strijd een totaal andere dimensie gegeven en hebben geleid tot een proliferatie van gewapende groepen. Gezien de aard van het geweld werden deze groepen gevormd binnen etnische gemeenschappen met als initieel doel de eigen bevolking te beschermen. Een voorbeeld hiervan is de Union Patriotique Congolais (UPC), een militie die door de politieke en sociale leiding van de Gegere-gemeenschap in het leven werd geroepen om de eigen gemeenschap te beschermen tegen gewapende groepen die de belangen verdedigden van andere etnische groepen. Hoewel de UPC ook kon worden geëvalueerd als het gevolg van een lokale verdedigingsreflex van een lokale etnische elite, werd deze groep belangrijk in de strijd om lokale politieke en economische controle in het laatste stadium van een strategie om de politieke en economische macht in Ituri te grijpen.

Vóór de formatie van deze gewapende groep had de nauwe samenwerking tussen Oegandese legercommandanten in Ituri en bepaalde politieke Gegere-leiders en ondernemers, tijdens de oorlog al tot de creatie van een grensoverschrijdend machtscomplex geleid dat bestaande handelsnetwerken kon monopoliseren en toegang had verkregen tot lokale natuurlijke rijkdommen, met als belangrijkste goud. Deze alliantie was uitermate succesrijk in het opwerpen van een alternatief en grotendeels staatloos proces van herverdeling, echter slechts ten voordele van de leden van de Gegere-gemeenschap. De UPC slaagde er na haar oprichting in deze positie van de Gegere-elites ook deels militair te con- 
solideren. De Gegere-gemeenschap zag bovendien in de UPC-leiding haar enige garantie op bescherming en bood volledige steun aan haar leden. Vreemd genoeg ontaardde de UPC snel van een politiek-militaire beweging die beweerde veiligheid te verlenen aan de Gegere, tot een goed ontwikkelde structuur van uitbuiting, niet alleen van niet-Gegere-gemeenschappen, maar ook in toenemende mate van de eigen achterban. In het gebied dat onder controle van de UPC stond, creëerde de UPC-leiding een klimaat van angst door willekeurige repressie en toenemende controle op economische activiteiten.

Het steunen van de UPC-militiestructuren, onder andere door het betalen van belastingen, werd steeds meer ervaren als een dwangplicht, terwijl de collectieve doelen van deze militie geleidelijk aan verdwenen. Een gelijke ontwikkeling kon trouwens worden waargenomen in het gedrag van andere milities in Ituri. Hoewel ze sterk waren ingebed in de plaatselijke Lendu-gemeenschap en zichzelf presenteerden als hun enige beschermers, handelden ook FNI-strijders steeds vaker tegen de lokale achterban. FNI-vertegenwoordigers dwongen hen tot gemeenschapswerk en namen hun toevlucht tot 'arbitrary arrests, beatings, and other forms of cruel and degrading treatment to obtain the maximum payment and service from civilians' (Human Rights Watch, 2005: 48).

Deze ontwikkeling van bescherming naar uitbuiting verdient in het kader van dit boek over etnisch geweld bijzondere aandacht. Tijdens vele bezoeken aan regio's onder controle van Mayi-Mayi en UPC werd vastgesteld dat, hoewel het officiële discours van collectieve bescherming meestal overeind bleef, de belasting op economische en sociale transacties ontaardde in afpersings- en onderdrukkingmechanismen. Dit werd gerechtvaardigd door het als 'effort de guerre' uit te leggen waardoor het aanvankelijk nauwelijks op weerstand stuitte bij de lokale bevolking. Dezelfde vaststelling gold voor de alternatieve regels voor het bestuur en de nieuwe rechtspraak die door de rebellen werden geïntroduceerd met als doel een zekere politieke orde te herstellen en straffeloosheid aan te pakken. Bescherming veranderde in uitbuiting en het streven naar gerechtigheid werd een excuus voor repressie. Dit is op zich een verschijnsel dat suggereert dat milities niet bij machte zijn om een geloofwaardig alternatief voor de staat te bieden. Maar klopt dit wel? Zijn etnische milities niet in staat echte bescherming te bieden en enig bestuur in te stellen in de regio's onder hun controle? En zo ja, waarom vallen zelfs de meest fervente verdedigers van de eigen gemeenschap uiteindelijk ten prooi aan de lokroep van machtsmisbruik en geweld? Het lijkt er alvast op dat in de meeste gevallen de verantwoording van bescherming werd omgekeerd.

Bescherming heeft een dubbele betekenis: 'One is comforting, the other ominous. With one tone, "protection" calls up images of the shel- 
ter against danger provided by a powerful friend, a large insurance policy, or a sturdy roof. With the other, it evokes the racket in which a local strong man forces merchants to pay tribute in order to avoid damage - damage the strong man himself threatens to deliver' (Tilly, 1985: 170). Maar dit is slechts een deel van de verklaring, afpersing en onderdrukking hebben immers hun beperkingen en kunnen niet grenzeloos worden toegepast als controlestrategieën. Marchal (2008) meent: 'the candidate warlord has to accept a number of social patterns that are beyond his own will: often he is as dependent on his people as they are on him'.

Dit is waar de belangen van de rebellenleiders en andere betrokkenen samenkomen: bescherming en afpersing zijn onderhevig aan constante onderhandeling die de toegang van de rebellen tot de lokale rijkdommen moet consolideren in ruil voor bescherming, en die de belangen van niet-statelijke instellingen moet dienen in ruil voor samenwerking. $\mathrm{Na}$ verloop van tijd slagen etnisch ingebedde gewapende groepen erin enige economische autonomie te verwerven, zodat deze lokale steun minder noodzakelijk wordt. Allianties met externe aanhangers maakten het bijvoorbeeld mogelijk om de noodzaak om sociaal ingebed te blijven te verminderen en de afhankelijkheid van lokale steun te reduceren. Toen de door Padiri geleide Mayi-Mayi-groep door Kinshasa werd benaderd en militaire bevoorrading werd toegekend in ruil voor steun tegen de RDC-rebellen, werd deze gewapende groep minder afhankelijk van lokale steun en legitimiteit voor haar eigen overleving. Vergelijkbare trends kunnen ook worden waargenomen bij andere milities op het platteland. Maar ook hier is er geen lineaire trend waar te nemen.

Waar gewapende groepen zich in toenemende mate tegen de bevolking keerden, poogden lokale chefs het niveau van geweld te reduceren door rechtstreekse onderhandeling met rebellenleiders. Zo trachtten niet-gewapende Gegere-leiders te onderhandelen met de UPC-leiding om hun 'machtsgebruik' te reduceren. Ook stedelijke intellectuelen die afkomstig waren van het controlegebied van Padiri's Mayi-Mayi en de lokale civiele maatschappij poogden etnische solidariteitsbanden aan te spreken om enige controle over het gebruik van geweld te verkrijgen. Dezelfde leiders uit de civiele maatschappij trachtten de rebellen ook te overtuigingen om ontwikkelingsinitiatieven te steunen en de sociale orde te promoten in deze erg gemarginaliseerde regio. De vraag blijft of deze onderhandelingspogingen effectief waren om het niveau van geweld te verminderen. Ook al kan er in bepaalde gevallen worden gesteld dat er minder geweld voorkwam wanneer dergelijke afspraken werden gemaakt, toch kon 'the array of local coping mechanisms which has emerged to help manage and reduce anarchy and insecurity' (Menkhaus, 2007) niet voorkomen dat diegenen die de bescherming van de bevolking als hun hoofdreden van bestaan propageerden, zich in toenemende mate tegen hen keerden. 


\section{Ethnicité par le bas? Identiteit en dagelijks overleven in de stad}

Als gevolg van staatsverval en conflict geven verwijzingen naar identiteit en etniciteit in toenemende mate invulling aan de inhoud van sociale en economische communicatie. Terwijl in het voorgaande sprake was van processen van etnicité par le haut, waarbij referenties naar identiteit een cruciaal onderdeel werden van mobilisatiecampagnes en strategieen van gewapende benden, is er in Oost-Congo ook een toenemend proces van etnicité par le bas te zien. Om dergelijke processen te illustreren wordt in het vervolg van dit hoofdstuk een korte analyse gegeven van de rol die identiteit vervult in de stedelijke veranderingen in Goma, de hoofdstad van de provincie Noord-Kivu. Deze stad, met een huidig aantal van 700.000 inwoners, is gelegen aan de grens met Rwanda en is in haar ontwikkeling sterk beïnvloed door gewapend conflict, de verzwakking van de staat, politieke concurrentie en humanitaire crises. Deze processen hebben geleid tot belangrijke stedelijke transformaties op politiek, economisch en sociaal vlak.

Gesitueerd in de periferie van de natiestaat en een belangrijk militair centrum tijdens de twee Congolese oorlogen heeft Goma zich ontwikkeld van een kleine, relatief onbelangrijke handelspost tot een invloedrijk, economisch centrum in de regio van de Grote Meren. Het valt hierbij op dat etnische identiteit een bepalende rol speelt, maar niet het enige referentiekader is bij de herpositionering van individuen en groepen in deze stedelijke transformatie. Als gevolg van haar karakter van dynamische regionale transitzone is de stedelijke bevolking in Goma samengesteld uit onderling zeer verscheiden etnische groepen en heeft de stad het imago verkregen van een 'kosmopolitisch' centrum. Al is er bij de lokale politiek een sterke competitie tussen elites die zich min of meer vertaalt via etnische lijnen, bijvoorbeeld als een strijd tussen Banyarwanda en Banande om de politieke en economische controle, toch lijken bij lokale, sociaal-economische structuren binnen de stedelijke bevolking deze breuklijnen veel minder aanwezig.

Etnische identiteit speelt zonder twijfel een belangrijke rol in het dagelijkse handelen en de interacties tussen de stedelijke inwoners, maar het is slechts een van de vele identiteiten die van belang zijn in en betekenis geven aan de stedelijke samenleving. We bespraken reeds de aanwezigheid van Banyarwanda in Noord-Kivu en hun vaak gespannen relatie met autochtone gemeenschappen. Gezien haar geografische ligging is in Goma een aanzienlijk deel van de stedelijke bevolking samengesteld uit Hutu en Tutsi, afkomstig uit buurland Rwanda. In de vroegste ontwikkelingen tijdens de koloniale periode werd de stad gedeeltelijk opgebouwd door Rwandese werkkrachten uit Gisenyi, Goma's Rwandese 'tweelingstad' (Bucyalimwe, 2008). Gedurende hun ontwikkeling 
zijn deze twee steden steeds nauw met elkaar verbonden geweest in een relatie van onderlinge afhankelijkheid. Als ogenschijnlijk één stedelijke agglomeratie kan Goma-Gisenyi worden gezien als een grenszone, of wat wel wordt genoemd borderland.

In deze context van intense interactie lijkt het op het eerste gezicht onmogelijk en irrelevant een onderscheid te maken tussen een Rwandese en een Congolese identiteit. Het zou interessanter zijn te vertrekken van een transborder identiteit die zorgt voor deze mobiliteit. Beide gemeenschappen zijn in hun dagelijkse activiteiten afhankelijk van de grens, die een belangrijke bron van mogelijkheden vormt. Een aanzienlijk deel van Goma's inkomsten is gebaseerd op grensoverschrijdende handel, vooral informeel, en voor veel bewoners van Goma geeft de toegang tot deze handelsnetwerken hen een bevoorrechte economische positie. De geografische grens tussen Congo en Rwanda lijkt in deze context bijna te vervagen; veel Rwandezen werken bijvoorbeeld in Goma vanwege de arbeidsmogelijkheden, onder meer in de enorme humanitaire sector. Veel Congolezen hebben bijvoorbeeld hun geld op een Rwandese bankrekening staan. Ook in de kleine dagelijkse zaken lijkt de grens op geen enkele manier een obstakel te vormen, bijvoorbeeld wanneer het erop aankomt om een goede internetconnectie te vinden.

In een dergelijke 'grens'-context, waarbij etnische, nationale en regionale realiteiten sterk in elkaar kunnen overlopen, valt te verwachten dat identiteit en identificatie van de stedelijke inwoners, nationaliteit, etniciteit en nationale en stedelijk 'burgerschap' zich op een steeds veranderende manier tot elkaar verhouden. Verschillende identiteiten hebben een zelfde betekenis in het socio-economische stedelijk leven. In de context van een zwakke Congolese staat wordt de ontwikkeling van Goma gekenmerkt door een vergaande informalisering, op alle vlakken en niveaus van de samenleving. Zoals elders in de Democratische Republiek Congo, beroepen ook Goméens zich op allerlei creatieve overlevingsstrategieën om het hoofd te bieden aan de vaak moeilijke levensomstandigheden. Deze inventieve maar noodzakelijke manier, voornamelijk in een stedelijke context, om met crisis om te gaan is het onderwerp geweest van recente antropologische en sociaal-politieke literatuur over Congo, (De Boeck en Plissart, 2004; De Villers et al., 2002; Lemarchand, 2001; Trefon, 2004). Door het structureren en organiseren van de samenleving van onderaf werden de Congolezen experts in wat wordt genoemd la débrouille of de kunst om uit alle mogelijkheden die zich voordoen in hun dagelijkse activiteiten en ontmoetingen een klein voordeel te halen. Identiteiten vormen een belangrijk onderdeel van deze overlevingsstrategieën, waarbij Goméens verscheidene identiteiten 'gebruiken', afhankelijk van de omstandigheden.

Wat Goma betreft, heeft de positie van de stad aan de grens, in de 
marges van de natiestaat, in het centrum van regionale economische netwerken, en in het centrum van gewapend conflict geleid tot de ontwikkeling van verschillende 'niveaus' van identiteit, van lokaal, nationaal, stedelijk, regionaal tot transnationaal, die hun eigen rol en functie hebben. Zo kan het bijvoorbeeld van belang zijn om zich te identificeren als Goméen, zich aldus een stedelijke identiteit aan te meten, wanneer het erop aankomt om handel te drijven in het commerciële centrum van Goma. Deze stedelijke identiteit benadrukt iemands verbondenheid met de stad, vooral met de centraal gelegen wijken, en is een manier om zich te onderscheiden van de periferie, van de deplacées of 'tijdelijke' stedelijke inwoners die veelal vluchtelingen uit het binnenland zijn. In een situatie waar handelaren met de lokale staatsautoriteiten dienen te onderhandelen over belastingen, is het interessanter om zich te onderscheiden als Congolees en die nationale identiteit te benadrukken, daar Rwandezen als 'vreemdelingen' vaak te maken krijgen met extra belastingen. In de constante zoektocht naar voordelen en manieren om het hoofd te bieden aan de complexe realiteit van Goma, wordt identiteit geïntegreerd in lokale overlevingsstrategieën en gemobiliseerd in het verwerven van bijvoorbeeld mobiliteit en toegang tot economische voordelen.

Geweld en conflict hebben deze identiteiten sterk beïnvloed. Al is de stad zelf nooit het toneel geweest van een direct gewapend treffen, toch heeft Goma meermaals een belangrijke rol gespeeld in het conflict in Oost-Congo. Gedurende de tweede Congolese oorlog (1998-2003) was Goma bijvoorbeeld de hoofdzetel van de rebellenbeweging, en tijdens de gevechten in Noord-Kivu tussen augustus en december 2008 leek de stad wel het centrum van militaire contestatie geworden toen rebellenleider Laurent Nkunda de stad kon omsingelen. De impact van deze laatste periode van intens geweld tussen het Congolese regeringsleger, de CNDP, onder leiding van Nkunda en lokaal gezien als een 'Tutsi-beweging', en het FDLR (de Rwandese Hutu-rebellen) was in Goma duidelijk voelbaar. Ondanks de verhoogde aanwezigheid van de VN-troepenmacht (MONUC) was er een opflakkering van stedelijk geweld zoals kleine criminaliteit, gewapende overvallen, verkrachtingen, en zorgde de grote militaire aanwezigheid in de stad voor nervositeit en onzekerheid onder de burgers. Daarnaast was er een sterke terugval van lokale economische activiteiten als gevolg van onder andere de aanwezigheid van gewapende groepen. Zij maakten de verbinding met het achterland moeizaam en gevaarlijk. En dat had weer zware economische gevolgen voor zowel de grote als de kleine handelaars. De stad werd opnieuw overspoeld door IDP's, ontheemden uit het geteisterde binnenland. Uiteindelijk heerste in de stad een zeer gespannen sfeer; de bewoners vreesden continu voor plunderingen of een inval door de rebellen, in complete chaos en paniek 
is alles mogelijk: 'dans des situations pareilles, le chaos fait des gens des fous; et ceux qui ont eu faim depuis longtemps, n'auront pas peur de manger' (interview Rosalie, Goma, oktober 2008).

Op verschillende momenten vonden er in Birere, het commerciële centrum van de stad en het hart van de informele economie, plunderingen op kleine schaal plaats, vaak op momenten van verhoogde spanning. Bijvoorbeeld toen Congolese troepen werden 'onthaald' in de stad, toen MONUC versterking stuurde naar het front of toen er nieuws binnenkwam van het oprukken van de rebellen. Op een gegeven moment werden er in de stad verschillende benzinestations aangevallen en vernield tijdens een vredesdemonstratie, omdat deze zogezegd in handen zouden zijn van 'sponsors van Nkunda', of van 'des antennes des agresseurs de l'autre coté Rwanda' (interview Stanny, Goma, oktober 2008). Geruchten over de Rwandese betrokkenheid in het gewapend conflict circuleerden op dat moment overal in de stad. Plots werd de aanwezigheid van Banyarwanda, en in de eerste plaats Tutsi, opnieuw een zeer gevoelig kwestie, zelfs in de grenswijken, waar Rwandezen en Congolezen samenwerken.

Geruchten over spionage resulteerden in een klimaat van wantrouwen en in een bijna paranoïde zoektocht naar infiltrées, opgezet door de lokale autoriteiten waarbij de verschillende chefs $d u$ quartier en chefs d'avenue zich verenigden om van deur tot deur 'illegale vreemdelingen', dat wil zeggen niet-Congolezen zonder 'geldige verblijfsvergunning' op te sporen en Tutsi's (of zij die daarvoor werden aangezien) werden in het openbaar verbaal en in enkele gevallen ook fysiek aangevallen. Uiteraard creëerden dergelijke acties een enorme nervositeit in de stad, wat vele Rwandese Goméens ertoe aanzette om bijvoorbeeld tijdelijk de nacht door te brengen in Gisenyi (Rwanda), uit 'veiligheidsoverwegingen'. Dit had aanzienlijke gevolgen voor de lokale economische activiteiten in de stad, waarbij duizenden Rwandese Goméens betrokken zijn. In dergelijke periodes van intens conflict, militaire dreiging, spanning en paniek krijgen identiteiten duidelijk een nieuwe dimensie. Het onderscheid tussen Rwandees en Congolees, tussen de ene en de andere kant van de grens, dat op andere momenten bijna irrelevant is in de sociaaleconomische omgeving van Goma, wordt plots de belangrijkste factor voor stedelijke inwoners om hun te identiteit construeren.

Aangezien conflict een intense competitie aanwakkert over de stedelijke economische, politieke en sociale ruimte, wordt in deze context identiteit vaak een kwestie van rechten, burgerschap en zich thuis voelen. Gewapend conflict zorgt voor een situatie waarin mensen trachten te overleven in een context van sterke competitie, verhoogde onveiligheid, economische onzekerheid, prijsstijgingen enzovoort. In deze situatie van algemene spanning is het van groot belang om zich op de juiste 
manier te identificeren en, nog belangrijker, op de juiste manier te worden geïdentificeerd door anderen. In een klimaat van wantrouwen en verdachtmaking hebben identiteitsprocessen belangrijke consequenties en komt het erop aan vooral niet te worden geïdentificeerd als zijnde 'van de andere kant'.

Terwijl Goma Rwanda sterk nodig heeft in haar economische ontwikkeling en de stad nooit zou kunnen zijn wat ze vandaag de dag is zonder de Rwandese aanwezigheid, worden als gevolg van het gewapend conflict de 'mentale' grenzen eens te meer versterkt. Identiteit wordt op die manier eerder een zaak van uitsluiting dan van insluiting, met een referentie naar die identiteit die het gemakkelijkst toelaat een onderscheid te maken tussen gevestigden en buitenstaanders. Het voorbeeld van Goma laat zien hoe identiteit van onderuit wordt gemobiliseerd in dagelijkse overlevingsstrategieën, in discours, acties en interacties die een socio-economisch in plaats van politiek karakter hebben. Het illustreert hoe identiteit niet enkel van bovenaf word georganiseerd, maar ook hoe mensen er op basisniveau zelf creatief mee omgaan. Deze manier van mobilisering van identiteit als variabele in socio-economische relaties in Goma leidt niet altijd tot conflict, zoals zo vaak wordt verondersteld. Het heeft gedurende de stedelijke evolutie geleid tot een lokale ontwikkeling gebaseerd op interactie en een overstijgen van etnische en nationale grenzen. Maar door het gewapend conflict zijn etnische breuklijnen versterkt. Maar het voorbeeld van Goma laat nog iets anders zien, namelijk dat dergelijke situaties van 'herdefiniëring' van sociale grenzen op basis van identiteit in tijden van intens conflict zeer tijdelijk en 'atypisch' zijn. Met het terugkeren van relatieve stabiliteit herneemt de 'normale' situatie in Goma zich snel.

\section{Conclusies}

Zes jaar na de ondertekening van het vredesakkoord in 2003 is er in Oost-Congo nog steeds geen sprake van duurzame vrede. De recente en intense gevechten tussen het CNDP onder leiding van Nkunda en het Congolese regeringsleger brachten tussen augustus 2007 en december 2008 opnieuw honderdduizenden Congolezen op de vlucht en leidden tot de zoveelste dramatische humanitaire crisis. Ook tijdens deze recente nieuwe opflakkering van geweld werd veelvuldig geprobeerd het conflict te verklaren als het gevolg van bestaande lokale etnische tegenstellingen. Veel had te maken met het discours dat werd gehanteerd door de strijdende partijen. Nkunda zelf sprak voortdurend over de noodzaak om de lokale Tutsi-bevolking te beschermen. Dit moest zijn strijd niet alleen de nodige legitimiteit verschaffen, maar diende als basis voor een populaire mobilisering, die in realiteit veel breder was en die een etni- 
sche gemeenschap ruim oversteeg. Hierdoor was een van de resultaten van deze recente fase van het Congolees conflict dat etnische tegenstellingen opnieuw werden verscherpt en geconsolideerd als verdelingsmechanisme binnen de lokale gemeenschap.

Dergelijke observaties dwingen om na te denken over de relatie tussen identiteit, mobilisatie en gewapende strijd. Terwijl uit het Congolese voorbeeld blijkt dat vooral in tijden van verhevigde politieke of gewapende strijd wordt gerefereerd aan identiteit in de hoop hiermee de noodzakelijke machtsbasis en legitimiteit uit te bouwen, kan hieruit niet worden afgeleid dat etniciteit vanuit een instrumentalistisch perspectief dient te worden beschouwd. Processen van etnische identiteitsvorming worden versterkt tijdens conflictsituaties, maar zijn niet zomaar een gevolg van conflicten. Referenties aan etnische identiteit geven immers ook in het dagelijkse leven betekenis aan sociale omgang en definiëren iemands positie binnen een samenleving. Meer zelfs: uit het Congolese voorbeeld kan worden afgeleid dat als gevolg van staatsverval, etnische solidariteit vaak de enige optie tot overleven is. Of zoals een lokale waarnemer stelt, 'etnicité est une réalité et un processus dynamique et mouvant et offre des espèces de niches écologiques de sécurité et de survie au sein d'entités étatiques fortement affaiblies' (Mbonyinkebe, 21).

In een context van verregaande informalisering van de politieke en economische ruimte verschuift etnische solidariteit van een cruciaal element voor het in stand houden van patronagenetwerken naar een essentieel onderdeel van informele sociale, politieke en economische netwerken. Etnisch gedefinieerde associaties, zoals de mutualiteiten, worden in een context van het falen van de staat en politieke desintegratie vaak de enige overblijvende vormen van bescherming. Daarmee worden ze ideale middelen voor mobilisatie in tijden van verhevigde politieke strijd. Tijdens deze mobilisatie is de boodschap zeer herkenbaar en raakt ze tot het diepst van ieders identiteit. Meer dan tien jaar van politieke en militaire mobilisatie heeft echter niet alleen geleid tot een verschuiving van het soort middelen van strijd, mobilisatie en verzet, zo werden de mutualiteiten vervangen door gewapende zelfbescherminggroepen en milities, maar het heeft ook gezorgd voor de consolidatie van etniciteit als een rigide referentiekader en als dominante sociale breuklijn.

Het verklaren van politiek geweld en conflict als etnisch geïnspireerd, miskent de complexiteit van hedendaagse conflicten als die zich in de Democratische Republiek Congo afspelen. Lemarchand merkt op dat 'ethnicity as a descriptor of violence is a poor guide to unravel the complexities of local conflict situations, their interconnectedness in time and space, and the manner in which they enter the consciousness of both actors and outside observers' (Lemarchand, 2001: 12). Toch mag de rol van etniciteit niet worden onderschat. Eerder dan de oorzaak van 
geweld vormt de referentie aan etnische identiteit zowel voor de veroorzakers van geweld als voor haar slachtoffer een onderdeel van weloverwogen strategieën om het hoofd te bieden aan een complexe situatie van competitie, crisis en geweld. Zoals het voorbeeld van Oost-Congo illustreert, is de vorming van een etnische identiteit een dynamisch proces, dat sterk wordt bepaald door de interactie van de individuen, groepen en gemeenschappen met hun socio-economische en politieke omgeving.

\section{Literatuur}

Bayart, J.F. (1993). The state in Africa. The politics of the belly. London: Longman.

Boeck, F. de en M.F. Plissart (2004). Kinshasa. Tales of the invisible city. Gent: Ludion.

Bucyalimwe, M.S.(2008).Goma(NordKivu,RDCongo).Pointdemireetdeparadoxe. (http://www.gomafocus.org/index.php?option=com_content\&view= article \&id=21:goma-nord-kivu-rd-congo-point-de-mire-et-deparadoxe\&catid $=4:$ histoire-congo\&Itemid $=19$ ).

Crummey, D. (ed.) (1996). Banditry, rebellion and social protest in Africa. London and Porthsmouth: James Currey and Heinemann.

Ericksen, H.E. (1993). Ethnicity and nationalism. Anthropological perspectives. London: Pluto Press.

Gnamo, A.H. (1999). The Rwandan genocide and the collapse of Mobutu's kleptocracy. In H. Adelman en A. Suhrke (eds.). The path of genocide. The Rwandan crisis from Uganda to Zaire. Uppsala: Nordiska Afrika institutet.

Hoffman, K. (2007). Militarised bodies and spirits of resistance. Armed governmentalities and the formation of militarised subjectivities in South Kivu. Roskilde: Roskilde University.

Hoyweghen, S. van en K. Vlassenroot (2000). Ethnic Ideology and Conflict in Sub-Saharan Africa, the Culture Clash Revisited. In R. Doom en J. Gorus (eds.), Politics of Identity and Economics of Conflict in the Great Lakes Region (p. 93-118). Brussels: VUB Press.

Human Rights Watch (2005). The Curse of Gold. New York: HRW.

Kaplan, R. (1994). The coming anarchy. The Atlantic Monthly, 273, 2, 44-76.

Lemarchand, R. (1994). Burundi: Ethnocide as discourse and practice. Cambridge: Cambridge University Press.

Lemarchand, R. (2001). The Democratic Republic of Congo: from collapse to potential reconstruction. Occasional Paper. Kopenhagen: University of Kopenhagen, Centre for African Studies.

Lonsdale, J. (1995). Moral ethnicity and political tribalism. In P. Meyns (ed.). Staat und Gesellschaft in Afrika. Erosions- und Reformprozesse. Duisburg: Schriften der Vereinigung von Afrikanisten in Deutschland. 
MacGaffey, J. (1987). Entrepreneurs and parasites. The struggle for indigenous capitalism in Zaire. Cambridge: Cambridge University Press.

Marchal, R. (2008). Warlordism and terrorism: how to obscure an already confusing crisis? The case of Somalia. International Affairs, 83, 6, 10911106.

Martin, D.C. (1995). The Choices of Identity. Social Identities, 1, 1, 5-20.

Mbonyinkebe, D.S. (2004). Crises Identitaires et constructions idéologiques: Approche socio-anthropologique. In Polé Institute, Les identités meutrieres: faire face aux defies posés par nos murs psychologiques et ideologiques (p. 21-24). Goma: Polé Institute.

Menkhaus, K. (2007). Governance without government in Somalia: spoilers, statebuilding and the politics of coping. International Security, 31, 3, 74-106.

Morvan, H. (2005). Réinventer le quotidien. La cohabitation des populations civiles et des combattants Maï-Maï au Kivu, Uppsala: Life and Peace Institute.

Mugangu, S. (1998). Terre, territoire et nationalité: les enjeux des conflits ethniques dans le Kivu montagneux (ongepubliceerde paper).

Tilly, C. (1985). War Making and State Making as Organized Crime. In P. Evans, D. Rueschemeyer en T. Scocpol (eds.), Bringing the State Back in. New York: Cambridge University Press.

Trefon, T. (2004). Reinventing Order in the Congo. How people respond to state failure in Kinshasa. London, New York \& Kampala: Zed Books/Fountain Publishers.

Villers, G. de, L. Monnieren en B. Jewsiewicki (2002). Manières de vivre: Économie de la 'débrouille' dans les villes du Congo-Zaire. Paris, Tervuren: L'Harmattan. 



\title{
Genocide in een Rwandees dorp
}

\author{
Jacob R. Boersema
}

\section{Inleiding}

De genocide in Rwanda in april 1994 lijkt de wereld meer te hebben geschokt dan enig andere volkerenmoord sinds de Holocaust. Voor de 800.000 onschuldige Tutsi-slachtoffers gebeurde dit echter helaas grotendeels achteraf. De huidige aandacht voor de Rwandese genocide - de afgelopen jaren kwamen er drie films uit Hollywood over de genocide - maakt het massale falen van de internationale gemeenschap ten tijde van de massamoord nog pijnlijker. Gezien deze aandacht is het verbazingwekkend dat er tot voor kort geen systematisch sociaal-wetenschappelijk onderzoek is gedaan naar de genocide in Rwanda. Wel verschenen er al kort na de massamoord uitstekende historische studies, onder andere van de onlangs bij een vliegtuigongeluk omgekomen Alison des Forges van Human Right Watch (1999). Deze studies vertellen gedetailleerd wat er in de noodlottige jaren van 1990 tot 1994 gebeurde in Rwanda, en hoe vanaf begin april 1994 het moordend geweld zich over heel Rwanda uitspreidde. De vraag naar het hoe en waarom van de genocide wacht echter nog steeds op een antwoord. In de populaire literatuur gaapt er een diepe kloof tussen de hoeveelheid verklaringen en het gebrek aan bewijs om deze theorieën te staven.

Ondanks deze kloof is er wél een consensus ontstaan over de rol van de aanstichters van de genocide. De moordpartij is op het nationale niveau georganiseerd door een kleine harde kern van extremisten in het leger en bij de overheid. De meeste extremisten hadden banden met Rwanda's regeringspartij Mouvement Révolutionaire National pour le Développement (MRND). Het succes van hun landelijke moordcampagne was te danken aan de succesvolle mobilisatie van het ambtenarenapparaat, loyale legereenheden, netwerken van politieke partijen en de media. Gezamenlijk zorgden deze ervoor dat de moordbevelen werden 
uitgevoerd en vele Hutu's werden aangezet tot geweld (Straus, 2006). Dat zo veel groepen konden worden gemobiliseerd laat zien hoe de staat een cruciale rol speelde in het orkestreren van de genocide.

Maar dit laat onverlet dat de grootste vraag over de Rwandese genocide nog steeds niet beantwoord is: hoe kon het dat honderdduizenden 'gewone' Hutu's meededen aan die moordpartijen? Was het manipulatie door de elite? Was het de armoede die ze hiertoe dreef? Was er een Rwandese cultuur van gehoorzaamheid of was het indoctrinatie? Of een combinatie van deze verklaringen? Tot nu toe hebben we nauwelijks antwoorden op deze vragen. Het enorme aantal slachtoffers van de Rwandese genocide - de schattingen lopen uiteen tussen de 500.000 en 800.000 doden - in de honderd dagen dat de moordpartij duurde, maakt deze vraag alleen maar prangender.

In dit hoofdstuk ga ik voornamelijk in op de vraag hoe de harde kern op het nationale niveau in staat was lokale handlangers te mobiliseren en hoe het geweld zich voltrok op het lokale niveau. Dit is een belangrijk stukje van de puzzel, dat tot nu toe onderbelicht is gebleven. Ik doe dit door het verhaal te reconstrueren van de commune (het Rwandese woord voor gemeente) van Runda. In deze reconstructie staat de intense lokale politieke strijd die aan het begin van de jaren negentig in het dorp uitbrak centraal evenals het verband met de uiteindelijke genocide die in het dorp begon op 12 april 1994.

Het verhaal van Runda is waarschijnlijk exemplarisch voor vele gemeentes in Rwanda in de periode van 1990 tot 1994. Het laat zien dat de nationale strijd om de politieke macht, zoals die in de hoofdstad Kigali gevoerd werd, minstens even heftig was in de gemeenschappen in de Rwandese heuvels. De beide niveaus van de strijd stonden ook niet los van elkaar. Een cruciale rol was weggelegd voor de kleine, politiekeconomische elite van de regeringspartij MRND. Die woonde weliswaar vaak in Kigali, maar voor hun politieke en economische macht leunden de leden in belangrijke mate op hun populariteit op het platteland. In de jaren tachtig was de maatschappelijke ongelijkheid tussen deze elite en de meerderheid van de bevolking sterk gegroeid.

Het democratiseringsproces van begin jaren negentig leidde tot een agressieve en gewelddadige afrekening met deze elite. Een deel, onder wie Claver Kamana uit Runda, was echter in staat, geholpen door de burgeroorlog en zijn machtsbasis in Kigali, om terug te slaan door een strategische etnische politiek te bedrijven. Leden van de elite wisten zo machtsverlies om te buigen in een campagne voor de macht. Dat deze politieke strijd uiteindelijk zou leiden tot een massale moordpartij op de Tutsi's was niet te voorzien. Maar dat de harde politieke strijd mede oorzaak was van het uiteindelijke geweld en het succes van de moordcampagne, lijkt evident. 
Het raadsel dat ik in dit hoofdstuk probeer op te lossen is hoe de lokale politieke strijd bijdroeg aan de genocide. Daarbij let ik speciaal op de dynamiek tussen het nationale en lokale niveau van de politieke strijd, gevolgd door het moordend geweld. Dit doe ik door zo nauwkeurig mogelijk de aanloop van de genocide in één gemeenschap te reconstrueren, vooral op basis van verslagen van ooggetuigen, de commune van Runda in de centrale provincie Gitarama. De interviews zijn afgenomen in de maanden augustus en september 2004. Door een gedetailleerd verslag van de lokale voorgeschiedenis in Runda en aandacht voor de rol van individuen wil ik antwoord geven op de recente oproep van academici dat we de verklarende kracht van lokale studies in de studie naar genocides niet moeten onderschatten (Bartov, 2003; Kalyvas, 2006; Tilly, 2003). Het lokale politieke krachtenveld waarin de genocide uiteindelijk plaatsvond, komt zo beter in beeld, evenals de sociale en politieke relaties die de genocide mogelijk maakten. De rol die Claver Kamana en Josef Setiba speelden als makelaars in politieke macht en later van geweld, brengt de dynamische relaties in Rwanda tussen het nationale en het lokale niveau in beeld. Een nationaal-lokaal perspectief vergroot de mogelijke theoretische verklaringen voor het geweld, door de aandacht te verleggen van de rol die etniciteit speelde, naar de dynamiek van het nationaal-lokale politieke proces (Kalyvas, 2003: 475-494).

\section{De staat van Rwanda}

Rwanda neemt een unieke positie in Afrika in. Lang voordat de Europese koloniale machthebbers Afrika opdeelden in nationale staten, kende het land een vorm van staatrechterlijke eenheid onder het koningshuis van de mwami (Newbury, 1993). Dit koningshuis bestond voornamelijk uit Tutsi's, terwijl de meerderheid van de onderdanen als Hutu's bekendstonden. Deze twee etnische groepen vormden echter min of meer een culturele eenheid, ze spraken dezelfde taal en deelden grotendeels eenzelfde cultuur. In tegenstelling tot vele Afrikaanse buurlanden, die te kampen hadden met een ineffectief staatsapparaat, heeft de lange voorgeschiedenis en culturele eenheid in Rwanda er altijd voor gezorgd dat de staat bijzonder effectief is geweest. Ze heeft altijd een indrukwekkende reikwijdte bezeten en een grote uitvoeringscapaciteit. Daarbij valt vooral het historisch zo gegroeide effectieve gebruik van de mobilisatie van massa's op. De effectiviteit van de staat berustte voor een deel op zijn geografische kenmerken. In het dichtstbevolkte land van Afrika, waar nauwelijks open ruimtes zijn, is de sociale controle altijd groot geweest en eenvoudig te handhaven. Dit historische gegeven betekende dat beleid afkomstig van de staat traditioneel altijd consistent was en gehoorzaam werd opgevolgd, ook als het ging om immorele bevelen. 
De vorming van de Rwandese staat voor de aankomst van de koloniale machten betekent echter niet dat Duitsland en vooral België als koloniale heersers geen invloed hebben uitgeoefend op de organisatie van de staat of de culture eenheid van de onderdanen. Hoewel het lastig vast te stellen is in welke mate er al ongelijkheid was, lijken de koloniale machten de ongelijkheid tussen de Hutu's en de Tutsi's op sociaal-economisch, cultureel en juridisch niveau te hebben bestendigd, dan wel actief te hebben gecreëerd en bevorderd. In zijn historische studie When Victims become Killers laat Mamdani (2001) zien hoe de koloniale machthebbers grote invloed hadden op de sociale structuren van Rwanda. Ze perverteerden niet alleen lokale machtsstructuren voor eigen gewin, maar schiepen ook een rechtsstelsel dat de inflexibele en ongelijke politieke identiteiten creëerde van Hutu's en Tutsi's (Mamdani, 2001). Tutsi's werden in dit systeem door de koloniale machten bestendigd in hun machtspositie, tevens werden ze, om hun verwantschap met de koloniale overheersers te benadrukken en te legitimeren, neergezet als vreemden in hun eigen land. Hutu's werden gezien als natives of inboorlingen, die terecht geregeerd werden door de superieure Tutsi's.

Een van de oorzaken van de genocide is volgens Mamdani dan ook precies deze koloniale constructie tussen Hutu's als het inheemse volk in Rwanda en Tutsi's als de vreemdelingen geweest. In de postkoloniale tijd heeft het Rwandese nationalisme dit schisma niet kunnen overwinnen (Mamdani, 2001: 34). Dit geldt zowel voor de Mouvement Démocratique Républicain (MDR), die vanaf 1960 regeerde onder Kayibanda, de eerste president van het onafhankelijke Rwanda en afkomstig uit het midden van het land, de provincie Gitarama, als voor de tweede president Juvinal Habyarimana. Deze bestuurde het land vanaf 1973 met zijn partij de MRND, een Hutu-coalitie die zijn basis had in het noorden van Rwanda. De koloniale creatie van etnische ongelijkheid speelt zo een belangrijke rol bij de oorsprong van de genocide, maar kan het geweld, en vooral de schaal van het geweld, slecht verklaren. Ook zijn er meer structurele, economische oorzaken aan te wijzen, die in samenhang met de koloniale staat en het politieke proces een rol hebben gespeeld. Een daarvan is uitgewerkt in Aiding Violence: The Development Enterprise in Rwanda (Uvin, 1998) waar de schrijver laat zien hoe de ontwikkeling van Rwanda, en vooral de ontwikkelingsgelden uit het westen, bijdroegen aan een groeiende ongelijkheid in Rwanda. De kleine politieke elite uit het noorden, die het land met dictatoriale macht vanaf begin jaren zeventig regeerde, profiteerde buitensporig van de grote instroom van zogenaamde apolitieke ontwikkelingshulp. Aan het begin van de jaren negentig had deze elite een enorme welvaart vergaard. Dit stond in schril contrast met de gewone burgers, rond die tijd nog altijd een van de armste bevolkingen van Afrika. Door een hoog geboortecijfer bij een zeer hoge bevolkingsdichtheid werd dit probleem verder versterkt. 
De ongelijkheid was op het platteland goed zichtbaar. De meeste politici hadden nauwe banden met de gebieden waar ze vandaan kwamen en woonden daar vaak ook nog. De tegenstellingen waren het grootst in het zuiden en midden van het land, waar de provincie Gitarama ligt. Het overgrote deel van de politieke top van de MRND woonde in het noorden en bevoordeelde dit gebied dan ook aanzienlijk. De elite in de provincie Gitarama was maar klein. Claver Kamana, de hoofdpersoon van dit verhaal, was een uitzondering. Hij was een van de weinige rijke mensen in Gitarama die goede verhoudingen had met het MRND-regime. Het was dan ook niet verrassend dat op het moment dat de onvrede politiek kon worden gemobiliseerd, hij het voornaamste slachtoffer zou worden.

In het begin van de jaren negentig zorgden twee belangrijke factoren dat deze structurele invloeden een noodlottige wending konden nemen, gezamenlijk hadden ze uiteindelijk een desastreuze invloed op de politieke ontwikkelingen. In 1990 begon een kleine groep voormalige Tutsivluchtelingen, verenigd in het Rwandese Patriottisch Front (RPF) een guerrillaoorlog vanuit Oeganda. Een jaar later werd Rwanda door het Westen gedwongen te democratiseren. Deze druk kwam voornamelijk van Frankrijk, een nauwe bondgenoot, omdat het Rwanda als onderdeel van francofoon Afrika zag. De eerste stap van dit proces was de introductie van een meerpartijenstelsel en de oprichting van oppositiepartijen, die al vrij kort daarna de zittende elite onder druk zetten. Gezamenlijk leidden deze ontwikkelingen tot een even onverwachte als heftige politieke strijd waarbij de etnische spanningen tussen Tutsi's en Hutu's volop inzet werden van de strijd. In de loop van deze strijd werd geweld zowel door de rebellen, de staat en enkele extremistische groeperingen steeds meer als een effectief middel gezien om de eigen doelen te bereiken. De combinatie van de burgeroorlog en de politieke strijd leidde er uiteindelijk toe dat genocide een 'aantrekkelijke' strategie kon worden voor een kleine maar vastbesloten extremistische groep binnen de gevestigde elite. Een strategie die uiteindelijk gruwelijk en verbluffend succesrijk in het gehele land werd uitgevoerd.

\section{Genocide als antwoord op een politieke crisis}

Het koloniale verleden, de etnische geschiedenis, de organisatie van de staat, de economische ongelijkheid, de burgeroorlog en het democratiseringsproces hielpen allemaal mee de omstandigheden te creëren die de genocide, en vooral haar uitvoering, mogelijk maakte. In The Order of Genocide laat Straus (2006) dan ook zien hoe de geografische spreiding en de dynamiek van het geweld bijna over heel Rwanda hetzelfde was. Uit een verdere vergelijking tussen vijf gemeenschappen blijkt ook dat de intensiteit van het geweld nauwelijks verschilde per regio. De geno- 
cide verspreidde zich onstuitbaar over het hele land, al duurde het in sommige regio's langer voordat het moorden begon. Er was nauwelijks variatie in de intensiteit van het geweld. Werd er eenmaal tot moorden overgegaan, dan was de uitvoering efficiënt en totaal. De uitkomst was overal hetzelfde: de Tutsi's werden zonder enig pardon uitgemoord.

Wat verschilt tussen de gemeenschappen is iets anders, namelijk het patroon van mobilisatie en de manier waarop de Hutu's tot moorden werden aangezet. Het resultaat kwam steeds op een andere manier tot stand. Het geweld tegen de Tutsi's werd telkens door verschillende coalities en groepen georganiseerd, soms door militairen en de vermaarde politieke jeugdbendes, Interahamwe, die vaak van buiten kwamen, soms door de zittende burgemeester en zijn politieke handlangers. In andere gevallen waren het rivalen van de zittende politici die het geweld organiseerden. De verschillende coalities slaagden er steeds in de 'gewone' Hutu door dwang en sanctionering in te zetten voor hun plannen.

Deze paradox tussen uniforme spreiding van het geweld en steeds andere patronen van mobilisatie is politiek te verklaren volgens Straus. Dit kan door de verspreiding van de genocide niet te zien als geboren uit chaos, noch uit een vooropgezette en goed geplande campagne, maar als uitkomst van een politieke strijd. Straus heeft het echter niet over de politieke strijd van 1991 tot 1994, maar over de strijd om de macht die uitbrak op het moment dat het vliegtuig met president Habyarimana werd neergeschoten, op 6 april 1994. Straus betoogt dat deze tot nog toe onopgeloste moordaanslag een cruciaal machtsvacuüm schiep. In zijn boek laat hij zien hoe tijdens de acute politieke crisis in de dagen na de moord op de president, er overal een interetnische strijd om de macht uitbrak, niet alleen op nationaal niveau maar vooral ook lokaal.

In de context van de burgeroorlog kon de oproep van de extremisten dat alle Tutsi's de vijand waren, fungeren als daadwerkelijk beleid: een gezaghebbend bevel en een basis voor autoriteit waar lokale coalities zich omheen konden formeren. Soms om de macht proberen te grijpen, in andere situaties juist om die macht te behouden. Vanaf het moment dat de extremistische coalitie de overhand kreeg in een gemeenschap werd het vermoorden van Tutsi's de norm en werden Hutu-burgers gedwongen mee te doen. Dat dit zo succesrijk kon gebeuren heeft volgens hem ook met de eerder besproken historische bestuursstructuur en cultuur te maken. In deze verklaring blijven twee zaken echter onderbelicht. Straus gaat niet in op het feit hoe de lokale machtsstrijd vlak na de genocide voortbouwde op de ontstane polarisering van het democratiseringsproces. In zijn onderzoek naar de lokale gemeenschappen richt hij zich volledig op de periode na het neerstorten van het presidentiële vliegtuig. De lokale politieke strijd op het platteland blijft bij hem buiten beeld. Er zijn echter veel aanwijzingen dat juist deze strijd bijdroeg 
aan de uiteindelijke moordpartij. Een tweede punt dat te weinig aandacht krijgt bij Straus is dat de machtsstrijd in vele gemeenschappen uiteindelijk werd beslist door militaire steun van de extremisten, of door ad-hoc georganiseerde regionale steun van extremistische partijen. Door dit niet te benadrukken wordt gemakkelijk over het hoofd gezien dat er wel degelijk sprake was van verzet. Dat verzet werd echter telkens snel overweldigd.

In tegenstelling tot wat veel studies suggereren hadden de burgeroorlog en de politieke competitie al in de vroege jaren negentig een grote invloed op de dorpsgemeenschappen op het platteland (Longman, 1995: 18-21; Wagner, 1998: 25-36). Voor het grootste deel van de jaren zeventig en tachtig hadden de Hutu's en Tutsi's vreedzaam samengeleefd. Verschillende publicaties aan het eind van de jaren tachtig van lokale gemeenschappen laten echter zien dat de ongelijkheid in de dorpen groeide (De Lame, 2005; Newbury en Newbury, 2000: 874; Jefremovas, 1992: 378-395; Platteau en Platteau, 1998: 1-47) De groeiende kloof tussen een kleine elite en de boeren, maar ook die tussen jongeren en ouderen, zorgden voor veel spanningen. De scheve machtsverhoudingen en de onduidelijke economische perspectieven voor de jeugd werden een voortdurende bron van conflict. Het uitbreken van de burgeroorlog deed die spanningen nog verder oplopen. Het democratiseringsproces maakte het echter voor het eerst ook mogelijk om deze gevoelens van ongenoegen om te zetten in politieke actie en vooral in strijd.

Voor mijn verhaal over Runda beperk ik mij tot een afgebakende tijdsperiode. De gekozen periode begint met het uitbreken van de burgeroorlog in 1990 en de introductie van een meerpartijenstelsel in 1991 en zal eindigen met de genocide in april 1994. Na een periode van politieke stabiliteit in Runda veroorzaakt de invoering van het meerpartijenstelsel in korte tijd een aantal heftige politieke gebeurtenissen. Deze deden de bestaande verhoudingen verschuiven en brachten een aantal lang bestaande onderhuidse spanningen aan de oppervlakte. Deze ontwikkelingen bleken uiteindelijk de opmaat voor de nationale genocide, waarin Runda als een van de eerste in Gitarama werd meegesleurd.

Een tweetal individuen staan in het verhaal van Runda centraal: Claver Kamana en zijn rechterhand Josef Setiba. Gedurende lange tijd was Kamana de ongekroonde koning van Runda en waarschijnlijk in heel Gitarama. Hij was een prominent lid van de nationale MRND, vicepresident van de partij in Gitarama, en partijpresident in Runda. Kamana was in 1935 geboren als de oudste zoon van een gemengd echtpaar. Hij had een Tutsi-moeder en een Hutu-vader. In de jaren zestig was hij, met hulp van Nederlandse ontwikkelingswerkers, zijn eigen bedrijf begonnen: Entreprise Kamana Claver, Hydrolique et Construction. In dezelfde tijd werd hij ook actief in de lokale politiek en bekleedde al snel de post van 
conseiller in zijn gemeenschap, een functie voor lokale leiders. Aan het einde van de jaren tachtig was zijn bedrijf uitgegroeid tot een van de grootste bouwbedrijven in het land. Hij gaf leiding aan honderden werknemers, grotendeels afkomstig uit zijn eigen dorp Runda. In het politieke en economische leven van de gemeenschap, maar ook sociaal en religieus, was hij de centrale figuur geworden en had uitstekende contacten met de nationale leiding van de MRND. Setiba was een medicijnman die begin jaren negentig als leider van de nieuwe jongerenbeweging JRND carrière maakte in de regerende partij MRND. De beweging werd later beter bekend onder de informele naam Interahamwe. De jongerenbeweging had als voornaamste doel politieke bijeenkomsten te organiseren. Maar ook om mensen te intimideren en politieke bijeenkomsten van de oppositie te verstoren. Samen zouden Kamana en Setiba over het lot van de Tutsi's in Runda beslissen als ze in april 1994 tot het moorden van Tutsi's aanzetten.

\section{Burgeroorlog en democratie}

De meeste Rwandezen, inclusief de regering, waren zeer verast door de invasie van het Rwandese Patriottisch Front (RPF) in 1990. De eerste aanval van de RPF duurde niet langer dan een maand en was militair allerminst een succes, maar zaaide veel angst onder de bevolking. De mensen in Runda herinneren zich die tijd goed. Een lokale ambtenaar zegt hierover ('I8' verwijst naar Interview 8 in de verzameling van gehouden interviews) het volgende. Per citaat wordt aangeven of de geïnterviewde een Hutu of een Tutsi is.

We did experience signs from the war, people were afraid, and people's activities decreased. They thought: 'Why should I work in the field when I maybe have to run tomorrow?' Instead of going into the field, people were talking among each other about the war. Some people also stopped their building activities. Not because of the money, but they did not want to build anything that would soon be destroyed (I8, Hutu).

De burgeroorlog kwam op een moment dat de meeste Hutu's al ontevreden waren over de onderdrukkende, corrupte en elitaire regeringstijl van president Habyarimana, die het land al bijna twee decennia regeerde. De rebellenbeweging van de RPF was echter niet de oppositie die zij zich hadden voorgesteld. De beweging bestond voornamelijk uit kinderen van Tutsi's die in de jaren zestig Rwanda waren ontvlucht na de onafhankelijkheid van het land. Slechts een enkele belangrijke positie in de beweging werd bekleed door een Hutu die bereid was te vechten 
voor een nieuw regime. Habyarimana reageerde door een massamoord op Tutsi's in het noorden, de precieze gang van zaken daarbij blijft echter onduidelijk. Misleidende berichtgeving in de media en repressieve reacties van de regering vergrootten verder de angst onder de bevolking. Deze angst bleek al gauw een vruchtbare voedingsbodem voor een nieuw soort anti-Tutsi-racisme. Extremisten portretteerden de aanval als een poging om de oude Tutsi-overheersing van de Hutu's te herstellen en stelden de Tutsi's in Rwanda verantwoordelijk voor de aanval.

Het toelaten van verscheidene politieke partijen, als stap naar een volwaardige democratie, bleek een nog explosievere verandering op het platteland. Traditioneel had de lokale elite zich verenigd rond de regeringspartij MRND. Deze partij had het bijna twintig jaar alleen voor het zeggen gehad. Plotseling was er ruimte voor oppositie. Lang weggestopte gevoelens van ongenoegen kwamen aan de oppervlakte, bijvoorbeeld over de regionale discriminatie in het onderwijs. De kleine lokale elite die het politieke leven domineerde in de dorpen, viel in afzonderlijke groepjes uit elkaar en er ontbrandde een heftige strijd om stemmen, privileges en macht. Lokale gemeenschappen veranderden in politieke slachtvelden.

Gitarama, de provincie waarin Runda ligt, had de eerste president van Rwanda voortgebracht na de onafhankelijkheid, Kayibanda, die het land gedurende tien jaar regeerde. Hij leidde de Parmahutu-MDR partij, de Mouvement Démocratique Rwandai. Deze partij werd snel heropgericht na 1991 en in haar kielzog gevolgd door verschillende andere kleinere partijen. Allen profiteerden van het ongenoegen opgebouwd in de twintig jaar van Habyarimana's regime. De oppositiepartijen wisten snel terrein te winnen en al gauw daagden zij de oude garde uit, die vooral uit machtsoverwegingen bij de MRND bleef. Na het oprichten van de MDR werd Kamana al spoedig het mikpunt van de kritiek van de oppositie. In het begin werkte de MDR nog samen met andere politieke partijen om de dominantie van de MRND te breken. Vele bijeenkomsten en protestmarsen werden georganiseerd, waar pleidooien werden gehouden tegen Habyarimana en zijn politiek van regionale discriminatie (I33, Tutsi).

Voor zakelijke opdrachten was Kamana natuurlijk sterk afhankelijk van de staat, wat een keuze voor de MRND - nog steeds de machtigste partij in het land - vanzelfsprekend maakte. De consolidatie van de positie van de MRND was cruciaal voor zijn bedrijf. Vele van zijn voormalige vrienden werden echter aangetrokken door de MDR en haar belofte van verandering en meer gelijkheid. Kamana verloor snel vrienden en invloed en alleen door omkoping was hij in staat enkele vrienden en lokale ambtenaren voor de MRND te behouden (I41b, Tutsi). Kamana's toewijding aan de MRND ging echter ook aanmerkelijk verder dan economisch opportunisme. Na de oprichting van de JRND, de jeugdorgani- 
satie van de MRND, ook bekend als Interahamwe, werd Kamana een van de meest toegewijde steunpilaren van de jeugdvereniging van de MRND. Een club die voornamelijk bekendstond om het lastigvallen van politieke opponenten.

Kamana had altijd goede contacten gehad met de jeugd. Jarenlang was hij de grootste financiële supporter van Runda Sport die grotendeels draaide op zijn financiële bijdragen (I2, Hutu; I10, Hutu). Zijn contacten kwamen begin jaren negentig goed van pas, omdat ze een goed aanknopingspunt waren voor het ronselen van jongeren voor de politieke partij. Het voetbalteam van Runda was altijd etnisch gemengd geweest. Maar dit veranderde met de politieke strijd en Kamana's volhardende steun voor de MRND. Een familielid van een van de voetballende Tutsi's vertelt wat er gebeurde na een wedstrijd in het seizoen van 1992 het volgende.

After the match, Kamana would talk about politics with the football players, about MRND and if they wanted to become a member. He said that publicly, he was not secret about it. If someone wanted to become a member himself, he went to Kamana secretly after the meeting. For anybody with some intelligence, it was obvious what Kamana was doing. Some wanted to, others did not (I39, Tutsi).

De helft van het voetbalteam zou spoedig enthousiaste leden van Interahamwe worden. Ook buiten de voetbalclub probeerde Kamana jongeren aan te sporen actief te worden voor de MRND. Hij praatte met ze over de MRND en de politieke situatie, waarbij hij ook gebruikmaakte van lokale leiders die als intermediair fungeerden tussen de jongeren en zichzelf (I33, Tutsi).

In 1992 verhardde de politieke strijd, op het nationale niveau, maar ook op het lokale niveau. In de dorpen op de heuvels gebruikten de politieke partijen steeds agressievere methodes om mensen bij het politieke proces te betrekken. Onder andere de introductie van het Kubuhozaritueel, wat 'vrij maken' in Kinyarwanda betekent, was daar de oorzaak van. Een nieuw ritueel waarbij leden van de tegenpartij of partijlozen, al dansend en zingend door partijleden werd gedwongen lid te worden. Oorspronkelijk geïntroduceerd door de MDR werd het al gauw door de MRND overgenomen. Het waren vooral de jongeren van de JRND die deze rituelen op mensen uitvoerden. Vele mensen werden zo gedwongen, soms zelfs met geweld, lid te worden of te blijven van de MRND. Hoewel Kubuhoza vooral op mannen werd uitgevoerd, gebeurde het hier en daar ook op vrouwen. Een Hutu-dame herinnert zich dat. 
They went to your house with a group and took your hat or your membership card and burnt it. When someone resisted, they were sometimes beaten very hard. It was in your interest to accept (I25, Hutu).

Door de politieke competitie radicaliseerden de jeugdverenigingen snel. De MRND was de eerste geweest met een jeugdvereniging, maar als reactie had ook de MDR haar eigen jeugdgroep opgericht, de JDR, die in populariteit en aantal deelnemers de MRND spoedig naar de kroon stak. In Runda ging de politiek het dagelijkse leven beheersen. Politieke discussies leidden vaker en vaker tot publieke scheldpartijen en gevechten in een van de vele lokale bars. Praktijken van gedwongen participatie werden ook gebruikt voor politieke bijeenkomsten, vooral de JRND was daar zeer bedreven in. Een Tutsi vertelt het volgende.

Sometimes the responsible asked us to participate in meetings from the MRND. If someone refused to come to a meeting, the responsible would come after the meeting, together with some young members of the JRND. They would dance and sing: Munda hario akaremereye (In the stomach there is a heavy thing). It meant that someone was angry with you. It was a common song in 1992 by the members of the MRND and JRND. Party members would come during the day, inside the compound, and they always asked the head of the household to come outside and dance with them (I41b, Tutsi).

Op het nationale niveau maakte de MDR in 1992 snel vooruitgang. Ze namen deel aan de tussentijdse regering en dwongen president Habyarimana te gaan onderhandelen met de rebellenbeweging RPF. Op het platteland was de strijd niet minder heftig. Op het hoogtepunt van de politieke campagne waren er bijna wekelijks politieke bijeenkomsten in de verschillende gehuchten die samen de gemeenschap van Runda vormden (I41b, Tutsi). De MRND was duidelijk in de verdrukking, wat misschien de reden wat dat partijleden steeds vaker geweld gebruikten. Een Hutu verhaalt.

In July 1992 the MRND had a meeting in Gihara sector. After the meeting MRND members threw stones at some members of the other political party. They hit someone who had to go to the hospital. A prominent MDR member was also hit. After they hit him, they even chased him all the way down to his house, but he managed to escape (I42, Hutu). 
Op hun beurt belaagden MDR-supporters ook Kamana. Regelmatig werd hij persoonlijk lastiggevallen, zijn auto vernield of stenen naar zijn huis gegooid. Op zijn beurt kocht Kamana regelmatig MDR-leden om voor informatie, om zo te horen over de plannen hem te boycotten of lastig te vallen. Hierbij maakte hij ook meer en meer gebruik van zijn nieuwe vrienden bij Interahamwe in Kigali. Een van hen, Josef Setiba, werd Kamana's rechterhand.

Setiba had in het begin van de jaren negentig in korte tijd carrière gemaakt binnen Interahamwe. In eerste instantie was hij bij de partij gevraagd door zijn buurvrouw, een Tutsi, die toen nog gewoon parlementslid was voor de MRND (I56; I68, Hutu). Setiba was nooit politiek actief geweest, maar had wel altijd goed verdiend met zijn medische praktijk en was een gewaardeerd lid van de gemeenschap. Setiba zegt hier later zelf over dat hij altijd een 'strong sense of obligation towards the government' had gevoeld. In april 1992 leerde hij toevallig Robert Kajuga kennen, de nationale president van Interahamwe en een prominent MRND-lid. Deze vraagt hem bij de JRND te komen. Setiba nam zo deel aan de eerste nationale vergadering van Interahamwe. Hij voelde zich daar gauw thuis. Hij zegt hierover later het volgende.

I firmly agreed with the explanation that all other parties were cooperating with the RPF. I had never liked them. They seemed to want to govern the country like they did before in 1959. And how could I like a party that came to kill? I enjoyed the group I became part of. I was suddenly part of something big. We were united, and had the same objective (I55, Hutu).

In december 1992 werd Setiba verkozen tot president van Interahamwe in zijn commune. Hij was goed in het ophalen van geld voor de partij en wist zich gesteund door een aantal belangrijke zakenlieden, onder wie Silas Kubwimana, een grote aannemer uit Taba en Claver Kamana. In juni 1993 volgde zijn verkiezing tot president van de JRND van grootKigali. Als hoofd van deze afdeling werd hij ook automatisch opgenomen in het nationale comité dat Interahamwe aanstuurde. Hij werd daarin verantwoordelijk voor 'discipline' in een sectie die de interne orde van Interahamwe handhaafde (I55, Hutu; I68, Hutu; I66, Hutu).

Als Kamana's rechterhand bezocht Setiba regelmatig Runda om informatie voor hem te verzamelen over de MDR (I68, Hutu) en speelde deze informatie door aan Kamana. Die kwam zo te weten wat de MDR van plan was, wie financiële problemen had en wie niet met elkaar over weg konden. Kamana's tactiek was er een van verdeel en heers. Toch voelde Kamana zich steeds meer bedreigd in zijn eigen dorp. Steeds vaker nam hij een aantal Interahamwe-leden mee, om hem te vergezellen 
en te beschermen (I55, Hutu). In de zomer van 1992 kwam de politieke machtsstrijd tot een uitbarsting als de MRND een grote politieke bijeenkomst in Runda organiseert. Een Hutu weet zich dat te herinneren.

That day Kamana lead a meeting at the football field in Runda. Afterwards Kamana and many MRND members came in minibuses and trucks to one of his bars. People thought that they were all Interahamwe. (I41a, Hutu).

Het bezoek van de grote groep MRND-aanhangers en Interahamwe zaait onrust onder de MDR-aanhangers en Tutsi's in Runda. Een Hutu zegt hier later over: 'As we heard the singing of the Interahamwe, we became very afraid' (I7, Hutu). Een Tutsi herinnert zich het volgende.

The rumor had it that they would hunt down Tutsis. They said that Tutsis had been killed in other areas of Rwanda. Many Tutsis did not dare to sleep in their houses and that night many went into the fields when it became dark (I27, Tutsi).

De politieke opponenten van de MDR zagen Kamana's komst echter ook als een kans. Zij hadden op de angst van de mensen in Runda geanticipeerd en zagen het als een uitgelezen moment om eindelijk met hem af te rekenen en het leiderschap van de gemeenschap definitief over te nemen. Ze namen zich voor Kamana voorgoed te verjagen, eventueel door hem te vermoorden (I48, Hutu). Op hun voorstel verzamelden zich bijna 200 mensen op het dorpsplein. Velen hadden stenen bij zich en een enkeling had een pijl en boog meegebracht. Een Tutsi herinnert zich dat.

Everyone was crying and shouting. We shouted aloud, so many people came for help. We had blocked the road. It was already dark when we saw the Interahamwe at night, saw them closing the door of the bar (I22, Tutsi).

Masejeschu en Karega, de leiders van de lokale MDR, voerden de massa aan. Vlak bij het plein in Kamana's café hadden ongeveer dertig Interahamwe-leden uit Kigali zich verzameld en enkele lokale leden hadden zich bij hen gevoegd. Op het moment dat Interahamwe de meute aan zag komen begonnen ze met stenen te gooien. De MDR-supporters beantwoorden de stenenregen met het gooien van hun stenen en het afschieten van pijlen. Het gevecht duurde niet lang. Geconfronteerd met de overmacht sloegen de Interahamwe-leden al snel op de vlucht (I47, Hutu). Een uitzinnige menigte trok vervolgens door naar Kamana's huis, maar daar aangekomen bleek die al te zijn ontsnapt naar Kigali (I41a, Hutu). 
Toen hij nog in het café was, had Kamana tevergeefs de prefect van Gitrama gebeld, en verteld dat hij aangevallen werd. Maar de prefect had niet thuis gegeven. Hij zag Kamana steeds meer als de belangrijkste oorzaak van het toenemende politieke geweld en als een bedreiging van zijn autoriteit in de provincie. De prefect verscheen pas de volgende dag, met een paar militairen, maar toen was het geweld al afgelopen (I47, Hutu). Vier Interahamwe-leden werden uiteindelijk gearresteerd en zaten voor enkele dagen in de gevangenis (I3o, Hutu). De verbanning van Kamana naar Kigali maakte een einde aan de politieke strijd in Runda en bracht de rust terug in het dorp. Als symbool voor de overwinning van de MDR plaatsten aanhangers een partijvlag op het centrale plein van Gihara, de tweede dorpskern van Runda (I30, Hutu).

Lang bleef het rustig in Runda, tot en met de zomer van 1993. Op dat moment verbrak de RPF de afspraken die eerder waren gemaakt tijdens de vredesonderhandelingen in Arusha in Tanzania tussen de regering en de rebellen en hervatte haar militaire offensief. Tegelijkertijd gaf het nieuw opgerichte radiostation RTLM de extremisten van de MRND een spreekbuis voor hun gedachtegoed. In hun programma's beweren ze dat alle Tutsi's RPF-handlangers zijn. In het bijzonder richten zij zich op PLleden, een kleine partij gedomineerd door Tutsi's. Zij werden neergezet als verkapte RPF-leden en aangesproken als Inyenzi, wat kakkerlakken betekent. De radioboodschappen bereikten heel Rwanda en vergiftigden steeds meer de relaties tussen Hutu's en Tutsi's. In Runda was ook een kleine, maar actieve PL-fractie die voornamelijk uit Tutsi's bestond.

$\mathrm{Na}$ het sluiten van het vredesakkoord van Arusha koos president Habyarimana en andere extremisten binnen de MRND ervoor de etnische kwestie nog harder te spelen. Zijn strategie was om zo de MDR, die bestond uit een gematigde en een meer extremistische groep, te splitsen. Door te benadrukken dat de RPF het vredesakkoord had verbroken én een Tutsi-partij was bood hij de extremistische fractie van de MDR een goede aanleiding om voor een etnische Hutu-alliantie te kiezen met de MRND in plaats van voor de gematigde partijlijn. De gematigde fractie van de MDR had de belangrijkste rol opgeëist tijdens het vredesproces, en wilde het vredesakkoord behouden. Het extremistische deel had zich buitengesloten gevoeld en was zeer ambivalent tegenover de behaalde resultaten. $\mathrm{Zij}$ voelden dat de MDR te veel concessies aan de RPF had gedaan, die ze zagen als een Tutsi-partij. De tweespalt over het vredesakkoord van Arusha zaaide veel onrust, zowel nationaal als lokaal. Tot aan het vredesakkoord had de MDR in heel de provincie Gitarama, inclusief Runda, bijna een jaar lang geruisloos geregeerd. Daar kwam nu abrupt een einde aan.

De politieke tijdbom barste met de beruchte toespraak van Karamira, de vicepresident van de MDR. Op 23 oktober vertelde hij een grote 
menigte in Kigali dat alle Hutu's moesten samenwerken onder de slogan 'MDR-power' en 'Hutu-power'. De toespraak werd live uitgezonden. Twagiramungu, de leider van de MDR en de onderhandelaar in Arusha, was volgens hem een verrader die samenwerkte met de RPF. De toespraak verdeelde de MDR tot op het bot, ook in de provincie. Sommige lokale MDR-leiders wilden de harde lijn volgen, anderen wisten niet hoe te handelen. Een MDR-supporter vatte het later goed samen: 'At the national level, the power ideology created unity among the Hutu, but at the local level it brought division.' En tot slot rond hij af: 'Only during the genocide it brought unity, maybe [...]' (I48, Hutu). Ook in Runda hoorden veel mensen de toespraak op de radio onder wie de lokale MDR-leiders. Zij hoefden niet lang na te denken welke kant ze zouden kiezen. Een zoon van een voormalig leider van de MDR vertelt het zo.

The local leadership was united on this point. There were a lot of discussions about power, but we all supported Karamira. We thought Twagiramungu was a thief, a traitor with no personality. He had been a friend of Habyarimana. He was a man that could not be trusted. In Gihara nobody could openly support Twagiramungu. Karamira wanted an MDR that was like the original Parmahutu party. But Twagiramungu wanted to do some modifications, but only in his own interests (I54, Hutu).

De leiders van de MDR in Runda namen zo een andere positie in dan de meeste MDR-leden in de provincie Gitarama, die massaal de gematigde koers van Twagiramungu steunden. Ook de prefect deed dat. Samen met andere MDR-leiders uit Gitarama schreef hij een brief naar de nationale leiding van de MDR dat zij de nieuwe powerbeweging sterk afkeurden (I55, Hutu). Runda was in dit opzicht dus een uitzondering. De keuze voor de powerbeweging maakte de weg vrij voor een nieuwe alliantie met Kamana's MRND. Deze was echter gedurende zijn tijd in Kigali steeds meer betrokken geraakt bij radicale activiteiten. Interahamwe maakte in het najaar van 1993 een kritieke ontwikkeling door. Vanaf oktober ontvingen vele leden, in ieder geval de leiders, militaire training (I66, Hutu). Ze bereidden zich voor op oorlog. Kamana had niet alleen deelgenomen aan het nieuwe trainingsprogramma, hij rekruteerde er ook jonge mannen voor in Runda.

In oktober organiseerde Kamana een grote MRND bijeenkomst op het voetbalveld van Runda. Verschillende lokale en nationale politieke leiders spraken, en, hoewel ze niet direct tegen de Tutsi's tekeer gingen, was hun taal weinig verhullend. Een Hutu herinnert zich: 'They did not speak openly against Tutsis nor of power, but they talked about how to fight the common enemy that had attacked us, that we have to fight 
and unite' (I27, Tutsi; I48, Hutu). De bijeenkomst was een groot succes. De immens populaire zanger Simon Bikindi, bekend om zijn anti-Tutsiteksten, trad op samen met zijn groep dansers (I39, Tutsi). Bijna een jaar lang was Kamana een persona non grata geweest, maar nu keerde hij met succes terug naar Runda. De bijeenkomst symboliseerde het moment waarop zich in Runda een MRND/MDR-powergroep ging vormen. Deze deed de oude politieke scheidslijnen vervagen, maar vergrootte de etnische spanningen. Wat tot dan toe een politiek gevecht was geweest tussen Hutu's onderling, werd langzaam een etnisch conflict.

De Tutsi's waren zich bewust van deze ontwikkeling en maakten zich ongerust (I55, Tutsi; I58, Hutu). Als kort daarna, in november 1993, de president van Burundi wordt vermoord zijn vele Hutu's woedend. Ze zien de aanslag en het offensief van de RPF als één complot. Toch blijft Runda tot april 1994 gevrijwaard van enig openlijk geweld tegen Tutsi's. Zoals een Tutsi-overlever het na afloop zou zeggen: 'There had never been open anti-Tutsi actions. I still drank with my Hutu friends everyday. We have been surprised' (I48, Hutu).

\section{De zesde april}

Op woensdag 6 april 1994 stortte het vliegtuig van president Habyarimana neer. De volgende dag verzamelen de mensen in Runda zich op het plein en in de cafés om de situatie te bespreken (I51, Tutsi). Niemand wist wat er te gebeuren stond, maar velen waren bang (I38, Hutu). De Tutsi's waren voorbereid op het ergste (I51, Tutsi) en hielden zich zo veel mogelijk afzijdig (I41b, Tutsi). Een Tutsi herinnert zich: 'People gathered in the streets and talked with each other, both Hutus and Tutsis. Although I must say, we Tutsis talked also among ourselves, what would happen to us' (I57, Tutsi). Tutsi's die overdag in het veld aan het werk waren geweest durfden 's avonds niet meer naar hun huis en bleven 's nachts in het veld. Pas in de ochtend konden ze controleren of hun huis nog onbeschadigd was en hadden ze tijd om de koeien te melken (I55, Tutsi). De lokale autoriteiten, onder leiding van de burgemeester, deden er alles aan om de situatie rustig te houden. In de namiddag van 7 april vielen enkele Hutu-extremisten in Kigese, een dorp aan de rand van Runda, een Tutsi aan. De burgemeester, bijgestaan door vier politieagenten, kwam echter tussen beiden en pakte drie extremisten op. De burgemeester van Runda leek de situatie onder controle te hebben, althans, dat dachten de meeste mensen van Runda toen nog. Zowel Hutu's als Tutsi's sliepen voor de veiligheid die nacht in of bij hun kantoor.

Het neerstorten van het presidentiële vliegtuig alarmeerde ook de prefect van Gitarama. Op 8 april verzocht hij alle burgemeesters bij hem te komen voor een bespreking. Ze bespraken de veiligheidssituatie en 
concludeerden dat ze tot dan toe goed in staat waren geweest de situatie rustig te houden. De prefect gaf opdracht geen enkele wegblokkade op te werpen of toe te staan, en om alle vluchtelingen zonder oponthoud door te laten (I55, Tutsi; zie ook Des Forges, 1999: 270). De burgemeester van Runda ging ook langs de leiders van de MDR om greep op de situatie te houden. Hij bleef zich echter zorgen maken over de situatie en voelde zich bedreigd. Een voormalig vriend zegt hier later over: 'In the evening he passed by my shop. I was there, and he asked me how I assessed the situation in Runda. I told him it was okay. The bourgmestre told me that he thought he would be killed' (I63, Hutu).

Claver Kamana was in Kigali op het moment dat het vliegtuig van de president neerstortte. Zoals zo velen wist ook hij in het begin niet wat er precies gebeurde. Samen met zijn familie had hij daarom zijn toevlucht in het Hotel de Mille Collin gezocht (I7, Hutu). Al snel bleek echter dat het Kamana's extremistische vrienden van de MRND waren die de macht hadden gegrepen. Op de ochtend van 7 april ontmoetten de leiders van Interahamwe elkaar op het kantoor van de prefect van Kigali. Josef Setiba, Claver Kamana en Silas Kubwimana waren ook aanwezig. Enkele JDRleden van de power-fractie woonden de bijeenkomst ook bij. De prefect van Kigali-ville, kolonel Tharcisse Renzaho, leidde de samenkomst. Het belangrijkste discussiepunt was de distributie van wapens in de verschillende buurten in de stad. Er werd besloten dat ze niet langer zouden wachten en onmiddellijk over zouden gaan tot het uitdelen van wapens aan de verschillende Interahamwe-eenheden.

De volgende dag was er een tweede bijeenkomst waarbij niet alleen de leiding van Interahamwe en de prefect aanwezig waren, maar ook enkele hoge militairen. Ook Kamana, Kubwimana en Setiba waren weer aanwezig. Dit keer werd besloten dat ook kerken mochten worden aangevallen, net als andere plaatsen waarheen veel Tutsi's waren gevlucht na het neerstorten van het vliegtuig, en dat ook lokale Interahamwe wapens uitgedeeld kregen. Zo zouden die kunnen deelnemen aan grootschalige aanvallen. Zo nodig zou Interahamwe geassisteerd worden door soldaten (I66, Hutu). Na afloop van de bespreking vertrokken Kamana en Kubwimana met de leiders van Interahamwe naar nog een privé bespreking. $\mathrm{Nu}$ in het hoofdkwartier van Interahamwe, Etamajore.

Tijdens die bespreking suggereerden Kamana en Kubwimana om ook Tutsi's in Gitarama aan te vallen, te beginnen met een aanval op Runda en Taba, een plaats vlak bij Runda waaruit Kubwimana verjaagd was. Kajuga en Ngurampatse, de leiders van Interahamwe, gingen hiermee akkoord. Kamana gaf Setiba de opdracht de aanval op Runda voor te bereiden en te leiden, Kubwimana zou de aanval op Taba aanvoeren. Setiba werd ook verantwoordelijk gemaakt voor de distributie van de wapens (I66, Hutu). De groep die Runda zou moeten overvallen 
bestond voornamelijk uit leden van de Interahamwe die oorspronkelijk uit Runda waren gekomen en inmiddels in Kigali woonden en daar ook een militaire training hadden ontvangen. Ze zouden bijgestaan worden door een kleine groep uit Runda zelf die vanuit het dorp zou opereren. Voorbereidingsbijeenkomsten zouden worden georganiseerd in Runda waarbij uitgelegd werd hoe de moordpartij zou worden georganiseerd (I69, Hutu; I53, Hutu).

Interahamwe werd ondertussen ook een steeds groter probleem voor de burgemeester van Runda. Setiba en enkele anderen kwamen een aantal keren naar Runda om mensen op te hitsen. Ze riepen dat de mensen 'aan het werk' moesten gaan, het beruchte eufemisme dat betekende dat mensen Tutsi's moesten gaan vermoorden. De burgemeester belde de prefect hierover op en vroeg om zijn assistentie. De prefect zegt hier later het volgende over.

On the $8^{\text {th }}$ of April Setiba had come with little trucks full of Interahamwe. The bourgmestre called me to say that the Interahamwe tried to attack. I asked eight soldiers to go, but when the soldiers arrived in Runda, Setiba had returned after pillaging some goods. The bourgmestre called for help, but he seemed to do nothing himself (I55, Hutu).

De pogingen van de burgemeester waren tevergeefs. Op 9 april pakte Setiba opnieuw zijn jeep, haalde zes Interahamwe-leden op, en reed naar Runda (I68, Hutu). Daar aangekomen ging hij direct door naar het kantoor van de burgemeester, hij liep naar binnen en toen hij de burgemeester gevonden had, sleepte hij die naar de voorkant van zijn kantoor. Daar had zich inmiddels een grote menigte verzameld. Hij schreeuwde tegen de burgemeester: 'Are you a Tutsi? Are you one of them? Are you? You stop the ones that went to work' (I63, Hutu; I5, Hutu; I51, Tutsi). Hij sloeg de burgemeester in het gezicht en beviel hem de cellen te openen waar de extremisten in zaten (I63, Hutu). Daarna sprak hij de menigte toe en maakte duidelijk wat hij van hen wilde: 'When we come back, we want to see all Tutsis being killed' (I39, Tutsi; I33, Tutsi; 41b, Tutsi). Uiteindelijk liep hij met zijn kompanen door het dorp om een paar bekende winkels van Tutsi's te plunderen. Overal waar hij kwam riep hij hetzelfde: 'Why don't I see a body of a dead Tutsi? Why don't you start doing your work?' Pas in de middag keerde hij terug naar Kigali, en nam de burgemeester mee. Die zou pas de volgende dag terugkeren (I22, Tutsi; I43, Tutsi).

De afstraffing die Setiba de burgemeester gaf, sloeg in als een bom. Het was vroeg op de ochtend, maar vele mensen hadden gezien wat er gebeurde. Onder hen waren veel Tutsi's die bescherming hadden gezocht bij de burgemeester. Setiba's minachting voor de autoriteit van de bur- 
gemeester was bij hen hard aangekomen. Voor hen was het duidelijk dat de burgemeester de controle had verloren en niet in staat zou zijn hen tegen Interahamwe te beschermen. Van de autoriteiten hadden ze weinig meer te verwachten, ondanks dat de burgemeester bescherming bleef beloven. Een Tutsi herinnert zich: 'In the evening the bourgmestre was back from Kigali and promised to continue to protect us. But we left however to Muganza, and spend the night there in the woods' (I43, Tutsi). Zoals eerder afgesproken op de achtste, kwam de prefect langs in Runda. Hij zou zo de burgemeester kunnen steunen, de bevolking bemoedigend kunnen toespreken, en de vluchtelingen doorsturen naar Gitarama-ville. Maar toen hij in de namiddag van 9 april arriveerde, zag hij dat er maar vijftig mensen waren gekomen voor hem (I55, Tutsi). Hij concludeerde hieruit dat de burgemeester had opgegeven.

In Kigali volgden de ontwikkelingen elkaar in hoog tempo op. Nadat het presidentiële vliegtuig was neergeschoten waren er onmiddellijk nieuwe gevechten uitgebroken. De RPF hervatte haar aanval op Kigali en bezette al snel de noordelijke buurten van de stad. De internationale gemeenschap was ook snel in haar besluit alle buitenlanders te repatriëren. En wat eerst alleen een paar gerichte politieke moorden leken, bleek al snel uit te lopen op massale executies van Tutsi's. Op 8 en 9 april begon Interahamwe ook 'veilige' plaatsen aan te vallen waar Tutsi's zich verzameld hadden. Omdat Kigali inmiddels was omsingeld door de RPF in het noorden en het oosten, was de enige vluchtroute voor haar inwoners naar het zuiden, de weg naar Gitarama en Butuare. Deze weg ging door Runda. Velen kozen ervoor hun biezen te pakken en te vluchten naar het platteland.

In Runda werd de situatie snel slechter. Het dorp was slechts een uur lopen van Kigali en al snel werd de plaats overspoeld door vluchtelingen uit de hoofdstad. Met de dag nam de stroom vluchtelingen toe (I15, Hutu; I1, Hutu; I43, Tutsi). De meeste vluchtelingen waren vrouwen en kinderen (I68, Hutu) en zij vroegen de lokale bevolking om onderdak en voedsel (I10, Hutu). De burgemeester opende de lagere school, maar er waren zoveel mensen dat velen moesten kamperen naast de weg of in de velden (I6, Hutu). De grote aantallen en het gebrek aan controle door de autoriteiten makkten dat zo een groot deel van de oogst vernietigd werd (I10, Hutu). De stroom bleef maar toenemen in de daarop volgende dagen. Met de vluchtelingen kwamen ook de eerste gruwelijke verhalen van wat er zich in Kigali afspeelde. De meeste vluchtelingen waren Hutu's en hadden gezien wat er in Kigali gebeurde, of er zelf aan hadden meegedaan. Een Tutsi-vrouw vertelt hier nu het volgende over.

The atmosphere deteriorated by the hour. Many of the refugees brought along their hatred and racism to Runda. Some of the 
people from Kigali, a majority being Hutu, came with machetes. They said: 'Hey, it stinks here, it smells like snake' (I22, Tutsi).

Ook de Tutsi-vluchtelingen die in Runda arriveerden zaaiden angst. Ze waren vaak maar ternauwernood aan de moordpartijen in Kigali ontkomen. Een Tutsi-vrouw herinnert zich hoe een vrouw aan haar deur klopte.

She told us that her husband had been killed. She had been hidden by a neighbor in Kigali, but was in total shock when she arrived in Runda. She told of all the Tutsis that were killed and of all the bodies that were littering the street in her neighborhood in Kigali (I22, Tutsi).

Op zondag 10 april reed er een karavaan met 'big cars with white people' door Runda, op weg naar de grens van Rwanda met Burundi, aangevoerd door een aantal auto's van de Verenigde Naties. De Verenigde Staten hadden een VN-escorte bedongen voor hun burgers. Mensen in Runda herinneren zich het lange lint van grote auto's. Een Tutsi-vrouw zegt hierover: 'It made us fear for the worst' (I28, Tutsi). Het was een beslissend moment voor de Tutsi's. 'All Tutsis at that moment knew what was going to happen', zegt een oude Tutsi-man later (I33, Tutsi). Rwanda's gewelddadige geschiedenis speelde hierbij een rol. De ouderen herinnerden zich het anti-Tutsi-geweld tijdens de vorige politieke veranderingen van 1958 en 1973 (I38, Hutu). Een oude Tutsi-vrouw zegt hier nu over: 'By the time the refugees had come, all Tutsis were afraid. Some already ran way, others were hiding' (I22, Tutsi). Een katholieke priester herinnert zich hoe de burgemeester gedwongen werd samen te werken met het nieuwe regime. Hij vertelt hier later over.

Just before the genocide I saw the bourgmestre with Beniga, the sous-prefect at Munini, in the south, a well-known extremist. He came one day and asked me: 'Are you going to leave?' 'Yes', I said, and he replied: 'In ten or fifteen days it is going to be calm again!' (I37, Spaanse priester).

Op 11 april was er nog een tweede bijeenkomst bij de prefect in Gitarama-ville. De burgemeester van Taba, Akayesu, vertelde de aanwezigen dat Kamana, Silas Kubwimanan en anderen de lokale Interahamwe aan het organiseren waren. Hij raadde ze aan om alert te zijn en klaar om te handelen. De groep besloot na afloop dat de prefect wederom alle gemeenschappen zou bezoeken om de bevolking een hart onder de riem te steken en de burgemeesters te steunen (I55, Hutu). Het kwam er ech- 
ter niet meer van. De prefect verloor steeds meer de controle over zijn eigen provincie. Steeds meer lokale groepen Hutu-extremisten en Interahamwe wierpen wegversperringen op. Ze begonnen de autoriteiten uit te dagen en maakten zich op voor een moordpartij op de Tutsi's.

\section{Het begin van de genocide}

In de vroege morgen van 13 april vertrok een konvooi van Interahamwe van Kigali naar Runda. Een voormalig Interahamwe-lid herinnert zich het volgende.

We left from the prefecture office in Kigali around 10 a.m. There was one convoy travelling to Runda, led by Setiba, and one to Taba. We brought guns to distribute to the local Interahamwe, and to the JDR power faction. Power was a Hutu - we said. Both groups went into one big bus; the weapons were put in two little Lorries. The bus drove first to Setiba's house in Kitiginy, on the way to Runda, to pick up more Interahamwe. Then the bus drove to the bridge, where it was stopped (I66, Hutu).

In Runda deed het gerucht spoedig de ronde dat de Interahamwe zou komen. De burgemeester en enkele gematigde leden van de MDR hadden zich verzameld bij de brug over de Nyabarongo, de toegangsweg tot het dorp. Er waren ook enkele politieagenten die waren aangekomen uit Gitarama-ville in opdracht van de prefect (I29, Tutsi; I38, Hutu). Toen de bus met Interahamwe bij Runda arriveerde werd deze gedwongen te stoppen bij de wegversperring. Setiba realiseerde zich dat hij niet door kon rijden zonder grof geweld te gebruiken en keerde terug naar Kigali voor versterking. In de hoofdstad bewapenden ze zich opnieuw, dit keer met rocket launchers (I43, Tutsi; I33 Tutsi; I35, Hutu; I68, Hutu). Bij terugkeer op de brug dreigden zij deze wapens te gebruiken tegen de politieagenten, die spoorslags in hun auto's vertrokken (I55, Hutu). Op dat moment was er niemand meer die Setiba en zijn aanhang tegenhield. Een deel van de Interahamwe stapte uit de bus en mengde zich onder de vluchtelingen en liep naar de top van de heuvel waar het centrum van Runda ligt. De Interahamwe zagen er angstaanjagend uit. Een oude Tutsi man vertelt.

They showed people their weapons. They had clubs with metal objects in it, swords, and machetes. They wore banana leaves and had their faces painted. Some wore masks so as not to be recognized (I33, Tutsi). 
Onderweg begon de groep op deuren te bonzen en mensen te controleren of ze Tutsi waren of niet. De rest van de groep reed door met de bus naar Runda en begon daar met het uitdelen van geweren en granaten aan handlangers (I66, Hutu). Setiba, die in een apart busje de wapens, munitie en het eten vervoerde, reed ook naar andere dorpen om daar wapens uit te delen (I68, Hutu). Al snel werd de eerste granaat gebruikt om een deur te forceren van een woning waar Tutsi's zouden wonen. Een Tutsi vertelt daarover.

I was cooking with my grandmother when I heard the sound of a grenade, I thought it exploded in the house of Calixte Karimuabo. We got up and left the house and joined my uncle who was already out. In the chaos I lost sight of my grandmother (I39, Tutsi).

Voor alle Tutsi's was het signaal luid en duidelijk. Een Tutsi die zich schuilhield op een heuvel zag het gebeuren: 'We saw the houses burning in Kigese and Sheri, we saw fire and smoke. Some Tutsis were running and we got very scared.' (I43, Tutsi). Ook Hutu's hoorden de ontploffingen en waren even onzeker wat ze moesten doen. Een Hutu-man herinnert zich: 'We heard the grenades and other guns at Kigese. We wondered if the war had started.' (I66, Hutu). Maar het was niet de oorlog die begonnen was. Het was een goed geplande operatie om de Tutsi's van Runda te vermoorden. Het plan bestond uit twee aanvalsgroepen: de eerste moest van huis naar huis gaan om de Tutsi's op te sporen en ze vervolgens te verzamelen en naar de rivier brengen. $\mathrm{Zij}$ hadden de handgranaten gekregen van Setiba (I53, Hutu). Een Hutu herinnert zich hoe hij door deze groep gerekruteerd werd.

In the morning of the first day of the genocide, Jean Paul Ruberanki'ko, Boudain, and Sankara came to me and asked: 'Why don't you go to work? Come with us.' They already had weapons. They told everybody where to go. Jean-Paul and Boudain gave orders. I think Setiba, and also Sankara led them. Jean-Paul was the main chief of my group (I66, Hutu).

Een tweede groep, geleid door oud-militair Jean Marie Hakizimana, zag toe op de identificatie van Tutsi's. Hij werd daarbij geassisteerd door Sankara, de landbouwdeskundige van Runda en een oude vriend van Setiba. Hij wist wie wie was in de gemeenschap en dat maakte het gemakkelijk de Tutsi's te identificeren. De Interahamwe en de (ex-)soldaten gebruikten eerst nog hun wapens om Tutsi's te vermoorden, maar al gauw ging de groep van huis naar huis om de Tutsi's met hun kapmessen te vermoorden. De groepsleiders beslisten steeds waar de groep heen zou 
gaan en dwong steeds meer lokale Hutu's mee te doen. Een aanwezige Hutu legt het later zo uit: 'In the beginning the group was small and had about twenty civilians. But as we were walking, the group just became bigger and bigger' (I44, Hutsu). Op het moment dat een mogelijke Tutsi gevonden werd, vroegen de leiders om zijn of haar identiteitskaart. Als het een Tutsi bleek te zijn, dan werd al snel tot moord overgegaan. Soms stormden leden van de Interahamwe ook huizen binnen en werd de heer des huizes aan een kruisverhoor onderworpen. Als het een Hutu bleek, dan werd hij gesommeerd zijn wapen te pakken en mee te doen met de groep (I44, Hutu). Soms splitste de groep zich op in enkele kleine groepjes om achter bepaalde Tutsi's aan te gaan.

In het begin gingen er veel geruchten rond over mogelijk verzet van Tutsi's en plaatsen waar Tutsi's zich zouden verstoppen. Eén gerucht was bijvoorbeeld dat er een lijst was van Hutu's die vermoord zouden worden door RPF-sympathisanten (I6, Hutu). Hoewel de Burgemeester bij de moordpartij aanwezig was, is zijn rol tot op de dag van vandaag onduidelijk. Mensen die weigerden mee te doen werden opgesloten in de gemeenschapsgevangenis (I69, Hutu). Vele Tutsi's probeerden te ontkomen. Op het schoolplein, in het centrum van het dorp, probeerden ze zich onzichtbaar te maken door zich te mengen met de vele vluchtelingen. Maar al gauw werden zij door lokale Hutu's herkend en aangegeven. Een Tutsi vertelt.

The local people separated us Tutsis from the Hutus. The people from Kigali were judges on their appearance. They gathered the local women and children on the square at the school. Some Interahamwe and people that collaborated with them brought some green beans. They held them in front of our noses and said 'too bad you cannot eat it'. They wanted to pester us about our hungriness. When they had gathered us all on the square the Interahamwe asked their chiefs what to do with us. They said: 'bring them back to where they come from: Abyssinia' (I41b, Tutsi).

Op het plein werden de mannelijke en vrouwelijke Tutsi's gescheiden. De meeste mannen werden onmiddellijk omgebracht en vluchtig begraven door ze in de toiletkuilen van de kerk en de school te gooien. De vrouwen en kinderen werd te verstaan gegeven dat ze naar de rivier moesten marcheren. Een Tutsi-overlevende schat dat er meer dan tweehonderd Tutsi's waren die te voet naar de rivier liepen (I55, Tutsi). De groep werd bewaakt door een menigte van zowel gewone Hutu's als enkele Interahamwe-leden. Een tweede groep van vooral Interahamwe had instructies gekregen de Tutsi's in de rivier te duwen (I66, Hutu; I41b, Tutsi). Een van de weinige overlevenden van de massamoord bij de rivier kan nog vertellen wat daar, op de brug van de Nyabarongo rivier, gebeurde. 
When we arrived at the river, we could see other people had drowned there. It was 10.a.m. when we arrived at the river. When the group of Interahamwe met the other group that was already at the river they told them not to drown them at once because there might be some Hutus left in the group. The Interahamwe checked everybody again, but there was no Hutu in our group. One by one we were ordered to jump into the river. At that moment, my fear had disappeared. I was ready to die. It felt like life was over. They cut the young boys in the neck and sometimes tied their hands, because they might be able to swim. Some women were also cut. I estimate there were about 200 Tutsis. Most of us could not swim, but if you could, you still did not have a chance. The Interahamwe stood on both sides of the river to keep pushing you back in, or kill you with their machetes (I41b, Tutsi).

\section{Ten slotte}

Uit de reconstructie van de gebeurtenissen in Runda aan het begin van de jaren negentig is een aantal conclusies te trekken. Deze conclusies liggen vooral op het vlak van de dynamiek van de politieke strijd en de rol van een aantal centrale personen die later ook bij de genocide waren betrokken. De reconstructie biedt uiteindelijk weinig inzicht in of antwoord op vragen over de oorsprong van het eventueel aanwezige cultureel anti-Tutsi-racisme. Ook wordt niet duidelijk wie precies deelnam aan de genocide en hoe en waarom. Wat de reconstructie toevoegt is een gedetailleerd verhaal over de Werdegang van een belangrijke genocide. Dit verhaal vertelt de gebeurtenissen die niet alleen de opmaat waren voor de genocide, maar ook wat die moorddadige strategie aantrekkelijk en mogelijk maakten. Dit maakt echter de uiteindelijke moordpartij nog steeds moeilijk te begrijpen.

Ten eerste blijkt uit de reconstructie dat het al voor de genocide onrustig was op het platteland. Net als op het nationale niveau moet ook lokaal het geweld van de genocide geplaatst worden binnen de politieke ontwikkelingen van het democratiseringsproces in de periode tussen 1990 en april 1994. De gebeurtenissen in deze periode hadden grote invloed op het latere geweld en het is misleidend om, zoals Straus (2006) lijkt te doen, ons tot het machtsvacuüm van na 6 april 1994 te beperken. Het verhaal van Runda maakt duidelijk dat de gang van zaken dan onbegrijpelijk wordt. Het is de verliezer van de politieke strijd in Runda, de MRND-politicus en zakenman Claver Kamana, die uiteindelijk de belangrijkste aanstichter wordt van de genocide in Runda. Het democratiseringsproces en het geweld zijn onlosmakelijk met elkaar verbonden, waarbij er nog niets gezegd wordt over het directe oorzakelijke verband. 
De centrale rol van Kamana in de politieke strijd en de genocide wijst, ten tweede, op de vervlechting tussen de politieke strijd om de macht in Rwanda (en Runda), en de onderliggende economische ongelijkheid. In 1991 gaf het democratiseringsproces een opening aan een nieuwe lokale elite om de bestaande elite uit te dagen. Dit deden ze voornamelijk door de bestaande onvrede onder de bevolking over de sociaal-economische ongelijkheid te verwoorden. De oppositie kwam voornamelijk van de MDR, die ook in de jaren zestig al de macht in handen had gehad, maar daarna verboden was geweest. De kleine elite van de MRND, al twintig jaar aan de macht en in Runda gegroepeerd rondom Kamana, werd de belangrijkste boeman voor de oppositie. De rijkdom die hem de politieke macht in eerste instantie had gebracht, werd uiteindelijk een symbool van de ongelijkheid waartegen zijn politieke tegenstanders vochten. De instabiliteit die deze strijd bracht, had niet zozeer te maken met de organisatie van de staat, maar eerder met de lange periode gedurende welke Kamana politiek machtig was en zijn fortuin had kunnen opbouwen. De ongelijkheid was sterk gegroeid en Kamana was gewend geraakt aan zijn alleenheerschappij.

De politieke strijd tot 1993, althans op het platteland, ging echter tussen twee partijen die voornamelijk bestonden uit Hutu's. Het was een interetnische aangelegenheid. De belangrijkste voedingsbodem van de strijd was sociale ongelijkheid. Het politieke doel was een nieuwe verdeling van de politieke macht die in Rwanda bovendien economische macht betekende. Dat de strijd uiteindelijk interetnisch zou worden was vanuit het gezichtspunt van de ontwikkeling in Runda moeilijk te voorspellen. Het is daarom noodzakelijk de gebeurtenissen in Runda in verband te brengen met de nationale ontwikkelingen en vooral de dynamiek tussen het nationale en het lokale niveau. Wat het democratiseringsproces in eerste instantie al wél met zich meebracht waren nieuwe, scherpere scheidslijnen in de gemeenschap en een serie gewelddadige en dwangmatige praktijken die later ook in extremere mate gebruikt zouden worden tijdens de genocide.

Ten derde lijkt de lokale dynamiek, vooral het verlies van de MRND aan de MDR, de nationale ontwikkelingen versterkt te hebben. Kamana was niet de enige die zijn macht (gedeeltelijk) had verloren. Zijn lot was exemplarisch voor een ontwikkeling die zich door heel de provincie Gitarama afspeelde. Hoewel er weinig onderzoek naar is gedaan, was hij waarschijnlijk onderdeel van een kleine elite van de MRND die de greep over hun gemeenschappen door de democratisering hadden verloren. Enkelen waren net als Kamana verdreven uit hun geboortestreek. De inmiddels verstedelijkte elite van de MRND had altijd haar binding met de achterban op het platteland in Gitarama behouden, gedeeltelijk voor hun politieke legitimiteit, maar ook uit economische noodzaak. 
Kamana's bedrijf bijvoorbeeld maakte gebruik van honderden arbeiders uit Runda en was veruit de belangrijkste werkgever in het dorp. De reïncarnatie van de oude MDR zette de MRND elite zowel politiek als economisch onder druk, en wist later, zowel door verkiezingen als door overvallen zoals op Kamana, de politieke macht in handen te krijgen.

In de aanloop van de genocide speelde deze in het nauw gedreven MRND-groep de hoofdrol. De leden stonden op het punt al hun macht te verliezen en voelden dat ze misschien weinig mogelijkheden meer hadden. Deze MRND-elite lukte het om de historisch al vaak succesvol ingezette etnische kaart verder uit te spelen en zo het succes van de MDR te ondermijnen. Dankbaar werd hierbij gebruikgemaakt van bestaand racisme tegen Tutsi's en de dominantie van Tutsi's in de RPF, die steeds verder oprukte. De MRND wist via deze tactiek de aandacht af te leiden van het eigen machtsverlies en de angst voor het gevaar van 'de Tutsi's' op te zwepen. De MRND-elite vond in haar etnische strategie steeds meer weerklank bij het extremistische deel van de MDR, dat zich tijdens de vredesonderhandelingen in Arusha benadeeld voelde en uiteindelijk koos voor een breuk met de gematigden in de partij en de Hutu-powerfractie van de MDR opzette. Vele leden van deze elite, inclusief Kamana, waren bereid tot het uiterste te gaan - het ontketenen van een volledige genocide op de Tutsi bevolking - om de politieke macht te behouden. De vraag waarom dit etnische argument zo gemakkelijk gespeeld werd - en hoe hij kon worden doorgevoerd tot in het extreme - is echter moeilijker te beantwoorden.

Claver Kamana is, zo blijkt uit de reconstructie, een zeer actieve speler geweest in de gebeurtenissen. Op een moment waarop hij voor de MDR had kunnen kiezen, al was het maar uit opportunisme, bleef hij de MRND trouw en ging hij mee in haar radicalisering. Na zijn smadelijke vlucht naar Kigali zinde hij duidelijk op wraak en was erop uit zijn positie in Runda te heroveren. Hij zette daar maar al te graag zijn aanzienlijke kapitaal, invloed en contacten voor in. Hij werd een belangrijke steunpilaar van de anti-Tutsi-strategie. Dit blijkt onder andere uit zijn grote financiële steun aan het nieuwe extremistische radiostation RTLM en zijn steun aan de Interahamwe. Deze steunde hij niet alleen, maar hij gebruikte hun leden ook actief in de politieke strijd, waarbij de beruchte Josef Setiba zijn belangrijkste vriend was en actief infiltreerde in Runda en zo het gezag van de MDR ondermijnde. Ook zijn latere aanwezigheid tijdens de genocide in een militair uniform geeft aan hoe diep hij betrokken was bij de extremisten die na 6 april de macht grepen.

De efficiënte organisatie van de staat zorgde ervoor dat de lijnen kort konden zijn in Rwanda. Het waren niet zozeer de netwerken - de tussenmannen - van Kamana die de lokale dynamiek bepaalden als wel Kamana zelf. Het zijn mensen zoals Kamana, de tussenpersonen die ope- 
reerden tussen het nationale en het lokale vlak, die cruciaal waren bij de genocide. Natuurlijk speelde Setiba een belangrijke rol, maar het is Kamana die de spil vormt. Zowel op het nationale als het lokale vlak is hij de persoon om wie de geschiedenis van de genocide in Runda draait. De invloed van patronagenetwerken, die Kamana zeker had en ook nog in die periode opbouwde, is complex. In eerste instantie konden ze niet verhinderen dat Kamana, inclusief zijn nieuwe Interahamwe-handlangers, verjaagd werd, maar later zette hij ze alsnog effectief in voor het omkopen van de MDR, nog later voor het uitbreiden van zijn Interahamwe en uiteindelijk voor het heroveren van de politieke macht door middel van de genocide op de Tutsi's in Runda. Kamana deed dit echter grotendeels buiten de staat om, uit de reconstructie blijkt duidelijk dat hij uiteindelijk niet in staat was de lokale overheid voor zich te winnen.

Als vierde kunnen we concluderen dat het geweld voor een deel werd gebruikt, hoe bizar dit misschien ook klinkt, om Kamana de macht weer in handen te geven in Runda. Het lijkt aannemelijk gezien de radicaliteit van deze strategie dat extreme racistische motieven een even grote rol moeten hebben gespeeld, maar daar kan op basis van de reconstructie geen uitsluitsel over worden gegeven. Het is evident dat het in meerderheid Kamana's mannen waren die mede tot de genocide aanzetten en ook uitvoerden. Het uiteindelijke geweld werd georganiseerd door een kleine groep getrainde Interahamwe. Deze groep bestond voornamelijk uit volgelingen van Kamana, maar werden gesteund door een kleine groep extremisten uit Runda van zowel MRND- als MDR-huize. Deze kleine groep blijkt echter met betrekkelijk gemak grote groepen Hutu's te hebben gemobiliseerd.

De vraag waarom zoveel mensen meededen kunnen we maar gedeeltelijk beantwoorden. Kennis van de voorgeschiedenis van de politieke strijd is hierbij instructief. Deze voorgeschiedenis kan in belangrijke mate hebben bijgedragen tot het gemak waarmee de kleine groep van Kamana erin slaagde door middel van groepsdruk en daadwerkelijk geweld medestanders voor de moorden te vinden. Een belangrijke oorzaak lijkt de herordening van het politieke landschap door de Hutupower-beweging. Het ontstaan van de MDR-power- en de Hutu-powerbeweging dwong de MDR-leden op het platteland te kiezen om vóór of tegen de extremisten te zijn. In Gitarama koos de meerderheid, zoals blijkt uit het verzet van de meeste burgemeesters en de prefect tijdens de genocide, voor de gematigde kant. Runda lijkt hier een uitzondering, omdat ze kozen voor Karimira. Misschien dat het netwerken van Kamana, het vakkundig stookwerk of de bijbehorende omkoping van hem hiertoe bijdroegen. De keuze maakte het in ieder geval voor Kamana mogelijk om in de maanden voor de genocide weer politieke bijeenkomsten te organiseren en in het dorp te verschijnen, en zo ook de haat 
jegens de Tutsi's onder de bevolking aan te wakkeren. Toch was er van een daadwerkelijk pact tussen MDR en MRND nog geen sprake. Vooral de weerstand van de burgemeester in de eerste week na het neerstorten van het vliegtuig laat dat zien. In de dagen voor de genocide doet Josef Setiba nog belangrijk voorwerk, onder andere door vakkundig het gezag van de burgemeester te ondermijnen. Maar uiteindelijk moet hij het verzet toch met geweld breken.

Het verhaal van Runda laat ten slotte zien dat het gebruikelijke onderscheid tussen geweld binnen de gemeenschap of van buiten de gemeenschap in Rwanda vals is. De Werdegang van Kamana maakt duidelijk dat hij zowel van binnen als van buiten de gemeenschap opereerde, al dan niet genoodzaakt daartoe door de ontwikkelingen van de strijd. Kamana verloor in eerste instantie politieke macht binnen zijn gemeenschap om uiteindelijk te radicaliseren op het nationale niveau en terug te slaan met hulp van buiten de gemeenschap. De 'Interahamwe van buiten,' die in veel studies worden genoemd, blijken in het geval van Runda wel degelijk jonge mannen uit het dorp zelf te zijn. Ze worden ook geleid door Setiba die al veel langer bekend was in de gemeenschap. De genocide in Runda was, ondanks de nationale verbanden, voornamelijk van eigen makelij.

\section{Literatuur}

Bartov, O. (2003). Seeking the Roots of Modern Genocide: On the Macroand Microhistory of Mass Murder. In R. Gellately en B. Kiernan, The Spectre of Genocide. Mass Murder in Historical Perspective. Cambridge: Cambridge University Press.

Forges, A. des (1999). Leave None to Tell the Story. Genocide in Rwanda. New York: Human Right Watch.

Jefremovas, V. (1992). Loose Women, Virtuous Wives, and Timid Virgins: Gender and the Control of Resources in Rwanda. Canadian Journal of African Studies, 25, 378-395.

Jefremovas, V. (2002). Brickyards to Graveyards. New York: SUNY Press.

Kalavas, S. (2003). The Ontology of Political Violence: Action and Identity in Civil Wars. Perspectives on Politics, 1, 475-494.

Kalyvas, S. (2006). The Logic of Violence in Civil War. Cambridge: Cambridge University Press.

Lame, D. de (2005). A Hill Among a Thousand. Transformations and Ruptures in Rural Rwanda. Madison: The University of Wisconsin Press.

Longman, T. (1995). Genocide and Socio-political Change: Massacres in Two Rwandan Villages. A Journal of Opinion, 23, 2, 18-21.

Mamdani, M. (2001). When Victims become Killers. Colonialism, Nativism and the Genocide in Rwanda. Princeton: Princeton University Press. 
Newbury, C. (1993). The Cohesion of Oppression. New York: Columbia University Press.

Newbury, D. en C. Newbury (200o). Bringing the Peasants back in: Agrarian Themes in the Construction and Corrosion of Statist Historiography in Rwanda. A Review Essay. The American Historical Review, 105, 823-877.

Platteau, A. en J. Platteau (1998). Land Relations under Unbearable Stress: Rwanda Caught in the Malthusian Trap. Journal of Economic Behaviour and Organisation, 34, 1-47.

Straus, S. (2006). The Order of Genocide: Race, Power and War in Rwanda. Ithaca: Cornell University Press.

Tilly, C. (2003). The Politics of Collective Violence. Cambridge: Cambridge University Press.

Uvin, P. (1998). Aiding Violence: The Development Enterprise in Rwanda. Kumarian Press.

Wagner, M. (1998). All the Bourgmestre's Men: Making Sense of Genocide in Rwanda. Africa Today, 45, 25-36. 



\title{
Het ontstaan van een pogrom in Gujarat
}

\author{
Ward Berenschot
}

Op de vroege ochtend van 27 februari 2002 arriveert een volle sneltrein in Godhra, een stadje in de deelstaat Gujarat in West-India. Daar krijgt een aantal passagiers ruzie met de moslim-theeverkopers op het perron; de treinreizigers weigeren om voor hun thee te betalen en zij zouden de theeverkopers dwingen: 'Jai Shri Ram' (leve de god Ram) te zeggen. De spanning op het perron loopt zo hoog op dat de machinist besluit eerder te vertrekken. Maar zijn trein komt niet ver, snel na vertrek wordt aan de noodrem getrokken en de trein komt even buiten het station tot stilstand, waarna een menigte de trein met stenen bekogelt. Om nooit opgehelderde redenen vat het interieur van een van de wagons vlam. Het vuur grijpt zo snel om zich heen dat slechts een enkeling kan ontsnappen; 58 passagiers komen om.

Dit incident vormt de aanleiding voor een van de grootste geweldsuitbarstingen tussen hindoes en moslims sinds de onafhankelijkheid van India. In de trein zaten vooral karsevaks, hindoe-nationalistische activisten van de organisatie VHP. Uit protest tegen de dood van 'hun' activisten roept de VHP op tot een staking. De VHP - letterlijk 'wereld-hindoeraad' - is een religieuze organisatie die de 'bescherming en verspreiding van hindoe-waarden' beoogt en in Gujarat veel aanhangers heeft. Nieuws over de dood van de 58 passagiers verspreidt zich snel, mede doordat de VHP samen met belangrijke politici beweert dat moslims de wagon in brand hebben gestoken. In bijna alle grote steden, maar ook op het platteland, komen grote massa's mensen op de been. Menigten van soms duizenden aanwezigen trekken op naar kleinere, geïsoleerde buurten, waar de moslimbevolking zich nauwelijks kan verweren. Er ontvouwt zich een grootschalige antimoslimpogrom waarbij volgens officiële cijfers 970 hindoes en 254 moslims sterven en vele anderen op onvoorstelbaar brute wijze worden verkracht, verbrand of verminkt. Tegelijkertijd 
worden de restaurants, winkels, fabriekjes, waterputten, riksja's en landbouwgrond van vooral moslims systematisch verwoest. Mensenrechtenorganisaties spreken van minstens 2000 doden. De economische schade wordt op bijna twee miljoen euro geschat. Aangezien het meeste geweld neerkwam op een gecoördineerde aanval door menigten hindoes samen met de politie op geïsoleerde moslimburgers, is het gerechtvaardigd om van een antimoslimpogrom te spreken.

De regering van Gujarat is direct betrokken bij de organisatie en uitvoering van de pogrom. De politie weigert niet alleen het geweld een halt toe te roepen; in veel plaatsen doet de politie zelfs actief mee aan de systematische aanval op de buurten waar moslims werken en wonen. Bedreigde moslims die de politie bellen, krijgen te horen dat 'we geen bevelen hebben om jullie te redden'. Veel ooggetuigen verklaren later dat zij hebben gezien hoe politici van de BJP, de hindoe-nationalistische partij, de menigtes aansporen. Zelfs ministers roepen op verschillende plaatsen menigtes op om 'moslims een lesje te leren'. Gujarats premier, Narendra Modi, zou de politie hebben opgedragen 'hindoes hun woede te laten uiten', en in de media verdedigt hij het geweld herhaaldelijk als een 'natuurlijke reactie' op de gebeurtenissen in Godhra.

Dit hoofdstuk bespreekt de rol die politici speelden bij het organiseren en aanzetten tot deze uitbarsting van geweld tussen hindoes en moslims in Gujarat. Het is vaak opgemerkt dan politici een belangrijke rol spelen bij het creëren van lokale spanningen en het uitlokken van geweld (Engineer, 1989; 1995). In de recente literatuur over Indiaas communaal geweld is er overeenstemming over hoe dit geweld geïnstigeerd wordt. Ondanks uiteenlopende, verklarende perspectieven richten de meeste recente publicaties zich op de manier waarop een aanleiding, zoals een religieuze processie, een lokale ruzie, een shockerende politieke gebeurtenis, gevolgen heeft in steden en buurten (Tambiah, 1996). Afhankelijk van de lokale politieke omstandigheden zal die gebeurtenis door politici worden aangegrepen om hun eigen (electorale) belangen te dienen (Wilkinson, 2004). De kans op communaal geweld lijkt het grootst in steden en regio's waar politici electoraal gewin kunnen halen bij spanningen op gemeenteniveau. In die gemeenten worden zij gesteund door netwerken van (extremistische) organisaties, zoals de VHP, de Bajrang Dal en de RSS, en individuen die zich bezighouden met het verspreiden van geruchten en het aanjagen van nieuwe spanningen (Brass, 2003). De leden van deze netwerken zijn erop gericht de spanningen tussen hindoes en moslim levend te houden door het verspreiden van een communale ideologie (Jaffrelot, 2003). Een klein incident kan al gauw geïnterpreteerd worden als een uiting van een breder communaal conflict. Als de activiteiten van deze netwerken niet geneutraliseerd worden door de politie of door de lokale gemeenschap van burgers (Varshney, 2002), kunnen politici 
grote menigten op de been brengen om grootschalig etnisch geweld te plegen. Ik wil laten zien dat de capaciteit van politici om tot geweld aan te zetten samenhangt met de manier waarop politici op dagelijkse basis bemiddelen tussen gewone burgers en staatsinstellingen.

Bij zulk etnisch geweld moeten we niet te snel aannemen dat geweldplegers met een beetje alcohol en geld kunnen worden overgehaald om geweld te plegen tegen mensen die vaak hun buren zijn. Zich alleen richten op electorale redenen om tot geweld aan te zetten, zoals in veel van bovengenoemde literatuur gebeurt, is onvoldoende om te begrijpen waarom politici tijdens rellen kunnen rekenen op de medewerking van burgers die deze electorale motieven helemaal niet delen. Er zijn verklaringen voor geweld die de motieven van elites integreren met de motivatie van de 'gewone' geweldpleger (vergelijk Horowitz, 1985: 140; 2002). Daarbij is een beter begrip nodig van de manier waarop politici in staat zijn om in te spelen op de angsten, behoeftes en dromen van degenen die het daadwerkelijke geweld plegen.

Om het functioneren van politici in India te begrijpen is het belangrijk dat we de 'weberiaanse' associaties van het begrip rationele staat opzijzetten (Migdal, 2001). Want het monopolie van de Indiase staat op het gebruik van geweld is beperkt en zijn vermogen om beleid uit te voeren en wetten te handhaven begrensd. In de praktijk moet de staat zijn soevereiniteit delen met een groot aantal niet-statelijke actoren (Blom Hansen, 2005), die een grote invloed hebben op de uiteindelijke uitvoering van overheidsbeleid en wetgeving. Politici kunnen via allerlei maatschappelijke instellingen invloed uitoefenen op het dagelijks functioneren van de overheidsbureaucratie (Fuller en Harris, 2001).

Staat en maatschappij worden gescheiden door een blurred boundary (Gupta, 1995) of een spongiform interface (Harriss-White, 2003), een schemergebied dat wordt bevolkt door allerlei (politieke) tussenpersonen die hun status en inkomen ontlenen aan hun vermogen om beleid in werking te stellen en aan het manipuleren van wetgeving ten gunste van hun cliënten. Vooral armere burgers maken gebruik van deze tussenpersonen, omdat zij moeite hebben om toegang te verkrijgen tot diensten die de staat te bieden heeft. Hun toegang tot gezondheidszorg, scholing en sanitaire voorzieningen is vaak niet zozeer gebaseerd op hun 'rechten' als staatsburger, als wel op hun vermogen om politieke tussenpersonen te bewegen om ambtenaren voor hen onder druk te zetten. Deze inspanning van politieke tussenpersonen is vaak gebaseerd op de impliciete belofte van een wederdienst, zoals steun bij verkiezingen. Vanwege de centrale rol die de uitruil tussen toegang tot staatsdiensten en electorale steun speelt in het functioneren van deze netwerken, zal ik deze netwerken in het vervolg patronagenetwerken noemen (zie Scott, 1972; Roniger, 1994; Chandra, 2004). 
Het communale geweld in Gujarat is beter te begrijpen door zich te richten op het dagelijkse functioneren van deze patronagenetwerken. Deze lokale netwerken die toegang bieden tot de staat overlappen namelijk grotendeels de netwerken van personen die in 2002 betrokken waren bij het instigeren en organiseren van het etnisch geweld. De politiefunctionarissen, buurtleiders, politici, lokale criminelen en de activisten van hindoe-nationalistische organisaties die een prominente rol speelden, werken ook in het alledaagse leven met elkaar samen om een lucratieve toegang tot de overheid en haar diensten te verkrijgen, en te behouden. De motivatie van deze personen om deel te nemen aan het geweld kan daarom begrepen worden in het licht van de positie van dezelfde mensen in deze patronagenetwerken.

We kunnen deze wederzijdse afhankelijkheidsrelaties in het 'schemergebied' tussen staat en maatschappij zien als een field of power (Bourdieu, 1999), een arena waarin allerlei (politieke) tussenpersonen concurreren om controle over staatsmiddelen te verkrijgen. De verschillende strategieën die politici gebruiken, kunnen in navolging van Bourdieu (1991) gezien worden als een resultaat van hun perceptie van het politieke spel dat zij spelen. Het 'structurerende principe' van dit spel is de beperkte capaciteit van de staat om wetten te handhaven en zijn burgers een uniforme toegang tot overheidsdiensten te bieden. Als gevolg hangt het electorale, vaak ook financiële, succes van politici voor een groot deel samen met hun capaciteit om mensen een eigen toegang te bieden tot staatsmiddelen. Om die toegang tot staatsmiddelen te ontwikkelen en te behouden moeten (aspirant-)politici dus relaties onderhouden met allerlei andere politici, ambtenaren en buurtleiders, maar soms ook criminelen. Ik zal een aantal algemene kenmerken van hun afhankelijkheidsrelaties schetsen om vervolgens te betogen dat het deze afhankelijkheidsrelaties zijn die de mobilisatie voor geweld mogelijk maken (voor een verdere uitwerking zie Berenschot, 2009).

Om het argument aannemelijk te maken zal ik mij richten op de gebeurtenissen in de wijk Gomtipur in Ahmedabad, Gujarats grootste stad. Deze relatief arme wijk was het gewelddadig middelpunt tijdens de rellen van 2002. Veel bewoners van Gomtipur hadden in de voorafgaande decennia hun baan verloren door het instorten van Ahmedabads textielindustrie in de jaren tachtig. De buurt kent veel werkloosheid; bewoners die wel werk hebben, verdienen hun inkomen als riksjachauffeurs, straatverkopers, bouwvakkers of fabrieksarbeiders. Gomtipur heeft een gemengde bevolking van vooral moslims en dalits. Dalits - ook wel onaanraakbaren of harijans genoemd - is de naam voor de kastegroepen die onderaan Indiaas complexe hiërarchie staan. Deze buurt werd begin 2002 geteisterd door terugkerende golven van geweld. Tijdens deze rellen speelde de lokale BJP-politicus Jitu Vaghela een prominente rol. 
De analyse van deze gebeurtenissen is gebaseerd op mijn veldwerk dat tussen januari 2005 en mei 2006 plaats vond. Meer dan een jaar lang zijn de lokale politici en hun aanhang gevolgd in drie buurten (waaronder Gomtipur) in de stad Ahmedabad. Twee van die buurten hadden veel geweld gezien, zowel in 2002 als tijdens eerdere geweldsuitbarstingen in 1969, 1985, 1990 en 1992. Een derde buurt was, ondanks een vergelijkbare gemengde bevolkingssamenstelling, al die jaren vreedzaam gebleven. Tijdens het veldwerk woonde ik in deze buurten, terwijl ik langzaam toegang kreeg tot lokale politieke netwerken en zo hun dagelijks functioneren kon bestuderen.

\section{De productie van geweld}

Gomtipur was een van de vele buurten waar het incident met de trein in Godhra explodeerde als een clusterbom. Soms bestond het geweld uit een botsing tussen hindoe- en moslimmenigten, maar het waren vooral grote menigten hindoes die samen met de lokale politie geïsoleerde moslimburgers aanvielen. De aanvallen waren schokkend wreed en vooral vrouwen werden het slachtoffer van verminking, marteling en verkrachting. In plaats van de slachtoffers te beschermen droeg de politie vaak actief bij aan het geweld door te schieten op de inwoners van de aangevallen buurten. Van de 29 mensen die volgens politiestatistieken tussen 28 februari en 22 april 2002 omkwamen in Gomtipur en twee aangrenzende buurten, stierven zestien mensen door politiekogels. Van de 29 doden waren er twee hindoe en 22 moslim (vijf onbekend).

Gedurende deze weken wist de lokale BJP-politicus Jitu Vaghela zich te onderscheiden. Hij hield antimoslimtoespraken in de wijkjes waar dalits woonden en hij voerde verschillende aanvallen op moslimburgers aan. Getuigen zagen hem menigtes aansporen om huizen van moslims in brand te steken en volgens veel lokale moslims is hij verantwoordelijk voor de moord op verscheidene bewoners. Op 31 maart arresteerde de politie hem wegens het aanzetten tot geweld. Op dat moment was hij een relatief onbelangrijke politicus; hij had in 2000 de gemeenteraadsverkiezingen verloren. Maar zijn toespraken, zijn rol tijdens de rellen en zijn arrestatie maakten hem beroemd. Grote groepen aanhangers gingen voor het politiebureau demonstreren voor zijn vrijlating. Toen hij na 108 dagen in de gevangenis te hebben gezeten, werd vrijgelaten was hij veranderd in een lokale held. Zes maanden later won hij de verkiezingen voor een zetel in het staatsparlement.

Het geweld in Gujarat was niet slechts, zoals Gujarats premier Narendra Modi had betoogd, een 'spontane reactie' op de brand in de treinwagon in Godhra. De getuigenissen van betrokkenen bij het geweld in Gomtipur suggereren dat het geweld was gepland en georganiseerd door 
een relatief kleine groep mensen. Een goed voorbeeld zijn de ervaringen van Akashbhai, een prominente leider in de buurt. Na de eerste weken van geweld besloot hij dat het tijd was om actie te ondernemen. Een buurjongen was overleden nadat een zelfgemaakte bom op zijn hoofd was ontploft. Akashbhai besloot politieke leiders te verzoeken zijn buurt beter te beschermen.

De situatie was erg gespannen. Het was tegen mijn principes, maar ik dacht dat als de atmosfeer nog verder verslechtert, dan hebben de mensen in mijn buurt geen wapens, zelfs geen stok. Ik ging naar de mensen van de BJP en ik vroeg: 'Als er hier 's nachts rellen zijn, wat hebben jullie gedaan om onze veiligheid te garanderen?' Daarna brachten deze mensen me naar plaatsen waar wapens gekocht konden worden. We gingen daar in het geheim naar toe, terwijl de rellen gaande waren. Op die plekken zag ik gemeenteraadsleden, een parlementslid, MLA's [leden van staatsparlement, WB] en zelfs religieuze leiders. Als ik mijn principes niet opzij had gezet, had ik dit alles niet ontdekt.

Een andere bewoner van Gomtipur observeerde het volgende.

Aan beide zijden gaat het maar om vijf procent [die het daadwerkelijke geweld pleegt, WB]. Tijdens de rellen kon ik dit goed zien vanaf het terras van een hoog gebouw. In het begin van de rellen waren er alleen wat 'antisociale' elementen en een paar VHPwerkers. Samen met een groepje naïeve jongeren, ongeveer 25-50 mensen. De VHP-werkers gaven hen wapens, ze geven hen geld en masala [tabak]. Ze lieten hen veel alcohol drinken. Dan ging dat groepje roepend de buurt rond. 'Ze komen eraan, ze zullen ons doden, ze gaan dit doen, ze gaan dat doen!' Die vijftig mensen bleven zo door de buurt rondgaan. De rest voelde angst; wat konden we doen als we echt aangevallen werden? Ik geloof dus dat het maar een kleine groep is die geweld pleegde. Aan beide kanten. De rest van de mensenmenigte was alleen maar bang.

Achter de uitbraak van ogenschijnlijk impulsief geweld ging planning en organisatie schuil; het geweld was niet alleen het product van emoties als woede en angst, maar ook het product van een complexe coördinatie tussen allerlei lokale actoren die op verschillende manieren het geweld mogelijk maakten. Op basis van de waarnemingen van deelnemers en toeschouwers kan een zekere taakverdeling onderscheiden worden. Bewoners van Gomtipur herinnerden zich bijvoorbeeld hoe de aanhangers van politieke partijen en hindoe-nationalistische organisaties bijeenkomsten in hun buurt organiseerden. 
Er zijn een paar buurtwerkers hier [leden van hindoe-nationalistische organisaties als de VHP of de RSS, WB]; zij brachten mensen samen in hun huizen. De bewoners en buren van een dergelijk buurtwerker werden uitgenodigd voor een meeting, zogenaamd voor cha-pani [gezamenlijk theedrinken, WB]. Daar zeiden ze dat hun leiders zullen helpen, en dat ze de politie onder druk zullen zetten [om hen te beschermen tijdens de rellen, WB]. Ze zeggen dat in ons Hindustan onze zussen en dochters worden lastiggevallen, dat ze [moslims] het vlees van koeien eten, dat ze verblijven in Hindustan op onze kosten, terwijl ze ons onder druk zetten. Op deze manier kwamen de leiders [naar ons toe] om mensen aan te zetten tot geweld.

Een andere bewoner beschreef deze besloten bijeenkomsten als volgt: "Mensen worden bang gemaakt door toespraken "achter het gordijn" tegen moslims. De leiders lieten twintig aanhangers een menigte bijeenbrengen en dan hielden ze hun toespraken.' De stroom van geruchten en vooroordelen in zulke toespraken creëerden een atmosfeer die de uiteindelijke mobilisatie voor geweld mogelijk maakten. Mede doordat de sprekers lokaal als leider werden gezien, konden hun woorden spanningen tussen hindoes en moslims aanwakkeren en het gebruik van geweld legitimeren.

Maar zelfs in de atmosfeer gecreëerd door deze buurtbijeenkomsten was een zekere organisatiegraad nodig om mensen uiteindelijk daadwerkelijk tot geweld aan te zetten. Veel energie en geld werd besteed aan het mobiliseren en aansporen van mensenmenigten. Volgens een buurtleider werden de geweldsplegers als volgt geworven. 'De mensen van de RSS, de VHP en Durga Vahini [vrouwenorganisatie van de VHP, WB] gaan eerst de buurt rond om mensen te vinden. Ze vinden uit welke mensen drinken en wie dringend geld nodig hebben. Ze maken contact met zulke mensen in twee groepen. De ene groep gaf het geld en de andere groep spoorde ze aan tot geweld. Dat kon tijdens rellen duidelijk gezien worden.'

Sommige aspecten van deze oproepen waren erg zichtbaar. In heel Gujarat getuigden slachtoffers dat de mensenmenigten die hen aanvielen werden aangevoerd door (BJP-)politici en aanhangers van de RSS, de VHP en de Bajrang Dal. Al deze organisaties vormden een onderdeel van de sangh parivar, de 'familie' van hindoe-nationalistische organisaties die in verschillende sferen van het openbare leven 'hindoe-waarden' verdedigen en die in Gujarat erg veel aanhang hebben. Politici van verschillend statuur - van staatsministers tot lokale partijactivisten - spoorden menigten aan om tot actie over te gaan. Maar, zoals de getuigenissen van bewoners van Gomtipur aangeven, hun bijdrage aan het geweld bestond 
niet alleen uit toespraken. De geweldplegers kregen geld, alcohol en tabak, zowel om hen te motiveren als om het plegen van geweld makkelijker te maken. Informanten beschreven hoe politieke werkers alcoholhandelaren benaderden met stapels geld. Deze handelaren werden gevraagd om mensen van grote hoeveelheden alcohol te voorzien. Nadat mensen op deze wijzen waren gerekruteerd, werden ze vaak in vrachtwagens van de ene locatie naar de andere vervoerd.

De rekrutering beperkte zich niet tot arme dronkelappen. Politici en hun werkers gingen ook langs bij mensen die in de buurt bekend stonden wegens hun capaciteit geweld te plegen. Van deze lokale goondas ('criminelen') werd verwacht dat ze de menigten van aanvallers zouden aanvoeren. Volgens getuigen gebruikten politici deze lokale criminelen ook om geweld uit te lokken: 'ze zorgen dat één iemand gedood werd, zodat de andere gemeenschap woedend was. Dan gaven ze hun communale toespraken, wat de moslims op hun beurt boos maakte, zodat die een tegenaanval begonnen.' Dit zijn de observaties van een lokale slijter (een verboden beroep in Gujarat) over de samenwerking tussen goondas en politici tijdens de rellen.

De politieke leiders ontmoetten ze [de goondas] vooraf [aan de rellen]. 's Nachts vroegen ze hen bij hun thuis te komen. [Tijdens de rellen] werd een dergelijk bijeenkomst gehouden in de chali [buurt] naast de mijne, een VHP-meeting met alle goondas van de buurt. De politici benaderden niemand zelf direct; bijvoorbeeld de werkers van Durga Vahini benaderden de vrouwen en de VHP-werkers namen contact op met de mannen. Dus verschillende mensen benaderden verschillende mensen en zij gaven alle informatie door aan de het gemeenteraadslid en de MLA. Pas als iemand verwond of gedood was, trad het gemeenteraadslid of de MLA naar voren om mensen tot geweld aan te sporen.

Verschillende commentatoren hebben opgemerkt dat lokale goondas een belangrijke rol speelden tijdens rellen (zie bijvoorbeeld Brass, 2003: 168). Vaak is betoogd dat 'without a nexus between politicians and criminals, big riots are highly improbable' (Varshney, 2002: 47). Lokale criminelen spelen een prominente rol tijdens de rellen; zij behoorden vaak tot de kleine groep die het daadwerkelijke geweld pleegden. De meeste mensen in gewelddadige menigten doen slechts mee uit nieuwsgierigheid naar het spektakel; lang niet iedereen durft daadwerkelijk geweld te plegen. Zoals een informant opmerkte: 'Gewone mensen kunnen geen wapens gebruiken. Maar als antisociale elementen [criminelen, WB] mee gaan doen, dan neemt hun kracht toe. Zij geloven dat deze mensen niet bang zijn om te sterven. Dus het publiek volgt hen, en de dadas [criminelen, goondas] gaan voorop.' 
Een verdere stimulering van het zelfvertrouwen van de geweldplegers was de impliciete en soms expliciete steun van de politici. In de woorden van een slagzin die tijdens de rellen op muren werd geschreven: 'andar ki bat hai, police hamre saath hai' ('dit is insiders informatie, de politici steunen ons'). De politie speelde een dubieuze rol in geheel Gujarat, maar in Gomtipur bood de politie de gewelddadige menigten bijzonder actieve ondersteuning. De politie weigerde niet alleen om de rellen te stoppen, politieagenten participeerden vaak in de aanvallen op moslimbuurten, door daar te schieten, benzine uit te delen en willekeurige moslims op te pakken. ${ }^{1}$ Onder druk van politici bleek de lokale politie vaak niet bereid te zijn om de meest prominente geweldplegers op te pakken; in hun plaats pakte de politie vaak willekeurige jongeren op, altijd gelijke aantallen moslims en hindoes. Zowel gedurende als na de rellen benaderden VHP- en RSS-aanhangers de politie om de vrijlating van gearresteerde geweldplegers te bepleiten.

Deze pressie op de politie is een belangrijk element van de organisatie achter het geweld. De capaciteit van politici en hun aanhangers om arrestaties te voorkomen, of om mensen vrij te krijgen, overtuigde potentiële geweldplegers dat de risico's van deelname aan de rellen beperkt zou zijn. Tijdens de speeches voorafgaand aan de rellen speelden beloftes van juridische en financiële hulp dan ook een belangrijke rol. Aldus een andere prominente bewoner van Gomtipur.

In die tijd gingen sommige hindoes, BJP-leiders en VHP-leiders, rond in onze chali. [Ze zeiden] 'Onze hindoes zijn advocaten, ze kunnen jullie uit de gevangenis krijgen. Ze zullen daar geen kosten voor vragen en totdat jullie uit de gevangenis worden vrijgelaten, zorgen we dat jullie allen te eten krijgen. Elke maand betalen we jullie familie 3000 rupees [ongeveer 60 euro, een klein maandsalaris, WB].'

In de maanden na de rellen zette de VHP inderdaad advocaten in die zeer effectief opereerden, zo blijkt uit geheime opnames die het tijdschrift Tehelka maakte van een gesprek met VHP-secretaris en advocaat Dilip Trividi die zich voor de VHP met veel rechtszaken bezighield. De advocaat gaf aan hoe hij zijn invloedrijke contacten gebruikte om mensen vrij te krijgen: 'Ik hoef deze mensen alleen maar te bellen. Wanneer iemand een probleem heeft, dan bellen ze mij. Ik denk dan wie de juiste persoon is [om dit op te lossen, $\mathrm{WB}$ ] en die breng ik vervolgens op de hoogte. Ja, zo hebben we het voor elkaar gekregen, door uit te vinden wie met wie goede contacten heeft. Godzijdank hebben we zo op alle plekken contacten, anders zagen die rechtszaken er slecht uit,' (Tehelka, 3-11-07). Herhaaldelijk ondernamen VHP-leden en BJP-politici pogingen 
om de politici, rechters of getuigen onder druk te zetten om veroordelingen te voorkomen. ${ }^{2}$

Het manipuleren van de rechtsgang was maar een klein gedeelte van de 'hulp' die aanhangers van hindoe-nationalistische organisaties boden. Sommigen distribueerden voedsel aan mensen die door de rellen hun huis niet konden verlaten. Anderen zetten tijdelijke vluchtelingenkampen op en weer anderen waren fulltime bezig in ziekenhuizen om te zorgen dat de gewonden goed behandeld zouden worden. Zij werkten hiervoor samen met verkozen politici, zoals een BJP-aanhanger vertelt: 'Toen Godhra gebeurde was ik van negen uur 's ochtends tot één uur 's nachts in het ziekenhuis. Ik had een pas voor de avondklok. Cocabhai [een gemeenteraadslid] was in het gebied [waar rellen plaatsvonden], en hij belde me steeds over steekpartijen, als iemand gewond was. In die tijd regelde ik de behandeling voor 107 gevallen.' De hulp die tijdens de rellen geboden werd had meestal een communale kleur. De VHP-, RSS- en BJP-werkers richtten hun inspanningen op de getroffen hindoebevolking, terwijl Congreswerkers - die vaak de toegang werden ontzegd tot hindoe-woonwijken - zich concentreerden op de moslimbuurten. De ondersteuning die deze organisaties boden, maakten het mogelijk om het geweld langer te laten voortduren; deze hulp hield de moraal hoog en vergrootte de populariteit en geloofwaardigheid van de mensen die betrokken waren bij het aanzetten van het etnisch geweld.

Met deze observaties van bewoners uit Gomtipur heb ik de contouren willen schetsen van een netwerk van mensen die samen de planning, oproep en organisatie van het geweld mogelijk maakten. Deze observaties laten zien dat een relatief hecht netwerk van gemeenteraadsleden, leden van het staatsparlement, MLA-, VHP- en RSS-aanhangers, politieagenten en aanhangers van politieke partijen, het organiseren en plegen van geweld mogelijk hebben gemaakt. De MLA Jitu Vaghela was een centrale figuur die de samenwerking binnen dit netwerk lijkt te hebben gecoördineerd.

De beschrijvingen suggereren bovendien het bestaan van wat Brass (1996: 9; 1997; 2003) een institutionalized riot system heeft genoemd. Een groep mensen 'in which known actors specialize in the conversion of incidents between members of different communities into communal riots'. De beschrijvingen ondersteunen Brass' claims over de specialisatie binnen deze netwerken. Onder de verschillende actoren die bijdroegen aan de rellen zijn verschillende fire tenders, mensen die geruchten verspreiden en communale spanningen aanwakkeren, te onderscheiden. Terwijl buurtleiders en politici functioneerden als conversion specialists die door hun gezaghebbende interpretatie van de gebeurtenissen in Godhra hielpen het geweld te legitimeren. Zo kunnen de goondas die door politici werden gerekruteerd ook riot specialists of riot captains wor- 
den genoemd. Net als Brass wil ik benadrukken dat de connecties tussen deze verschillende personen al voor de rellen bestonden.

Maar deze netwerken zijn niet alleen maar riot systems. Deze netwerken zijn niet opgezet met het doel om spanningen tussen bevolkingsgroepen te creëren of om geweld te organiseren (vergelijk Brass, 1996: 13). We kunnen het functioneren van deze netwerken tijdens rellen beter begrijpen in het licht van het functioneren van dezelfde netwerken tijdens vrediger tijden. Deze netwerken zijn dan geen riot systems, het zijn patronagenetwerken die de interactie tussen staatsinstellingen en burgers mogelijk maken. De connecties tussen goondas, politici, lokale fire-tenders en de politie zijn niet ontstaan uit een gedeeld belang bij het aanzetten tot geweld. Ze zijn voortgekomen uit de dagelijkse samenwerking die nodig is om een controle over het functioneren van staatsinstellingen te verwerven.

Voor deze relatie tussen Gujarats communale geweld en de dagelijkse bemiddeling van de staat zal ik drie argumenten aanvoeren: (1) de netwerken van actoren betrokken bij het aanzetten en organiseren van geweld zijn niet te onderscheiden van de patronagenetwerken die de interactie tussen staatsinstellingen en burgers mogelijk maken; (2) de capaciteit van lokale leiders om toegang tot staatsdiensten te bieden verschaft hen de noodzakelijke autoriteit om tot geweld aan te zetten; (3) de motieven van verschillende deelnemers aan communaal geweld kunnen begrepen worden in het licht van de positie van deze actoren in de lokale patronagenetwerken.

\section{Geweldsnetwerken en de toegang tot de staat}

De contacten tussen de partijaanhangers, lokale criminelen, politieagenten en politici die het geweld in Gomtipur mogelijk maakten, zijn niet ontstaan uit een gedeeld belang bij het organiseren en aanzetten tot geweld; hun samenwerking tijdens rellen is het product van de dagelijkse samenwerking tussen deze actoren. Wegens het bemiddelen tussen staatsinstituties en burgers moeten zij dagelijks met elkaar samenwerken. Dit creëert de infrastructuur die, ten tijde van communale spanningen, gebruikt kon worden om wapens te distribueren, mensen te mobiliseren en het ingrijpen van de politie te voorkomen.

De lokale politici die ik volgde in hun dagelijkse routine besteedden bijna al hun tijd aan het helpen van burgers om toegang te krijgen tot overheidsinstellingen. Dat was het meest zichtbaar 's ochtends op de straathoeken van vooral armere buurten. Daar ontvingen politici een niet-aflatende stroom bezoekers die hen kwamen vragen om bepaalde ambtenaren onder druk te zetten. Deze burgers hadden de interventie van politici nodig om een weduwepensioen te regelen, de watervoorzie- 
ning te verbeteren, een plek voor hun kinderen op een goede school te regelen, papierwerk in orde te maken, een politiezaak op te lossen en nog veel meer. Lokale politici hebben nauwelijks tijd voor het maken van nieuw overheidsbeleid; de meeste aandacht en tijd besteden ze aan het onder druk zetten van ambtenaren om problemen op te lossen. Deze bemiddelende rol van politici is zo verweven in het dagelijks functioneren van staatsinstellingen dat er sprake is van een mediated state (Berenschot, 2009), waarin zowel overheidsbeleid als ambtelijke procedures ervoor hebben gezorgd dat de interactie tussen burger en overheid voor een groot deel is gemonopoliseerd door politieke actoren.

De afhankelijkheid van burgers van deze politieke bemiddeling structureert de space of play (Bourdieu en Wacquant, 1992) van politici die deze afhankelijkheid gebruiken om verkiezingen te winnen en macht te verwerven. In een dergelijk politiek 'veld' wint de politicus moeilijk verkiezingen met slechts mooie beloftes en slimme beleidsvoorstellen. Niet alleen politici ontlenen hun carrière aan het ontwikkelen van controle over de distributie van staatsmiddelen. De afhankelijkheid van burgers van politieke tussenpersonen brengt wijdvertakte en veelzijdige netwerken voort. Op hun beurt ontlenen de tussenpersonen hun lokale status en vaak hun inkomen aan hun capaciteit om verzoeken van burgers door te spelen aan invloedrijke politici en machtige ambtenaren. In buurten als Gomtipur zijn leden van politieke partijen en buurtleiders met politieke connecties in bijna elke straat te vinden. Dankzij deze connecties kunnen deze, soms tegen betaling, allerlei problemen voor hun buren oplossen en zo hun reputatie vestigen als goede buurtleider.

Zo zorgt de afhankelijkheid van politieke bemiddeling voor allerlei wederzijdse afhankelijkheden. De buurtleiders hebben politici nodig om lokaal aanzien te verwerven, omdat politici voor hen buurtproblemen kunnen oplossen. Tegelijkertijd hebben politici, vooral ten tijde van verkiezingen, de steun en medewerking van deze lokale tussenpersonen nodig. De lokale competitie om macht en aanzien gaat gepaard met een complexe uitruil van gunsten. Hun capaciteit om problemen voor hun achterban op te lossen hangt samen met de hoeveelheid gunsten die ze in het verleden hebben verleend aan invloedrijke politici en ambtenaren. Door deze invloedrijke leiders te helpen kunnen lokale politici hun toegang tot de overheid versterken. De uitstaande 'rekening' van gunsten en de perceptie die anderen van die 'rekening' hebben is een belangrijk bestanddeel van de status en aanzien van lokale politici en buurtleiders.

Een vergelijkbare uitruil van gunsten vindt plaats tussen politici, lokale criminelen en de politie. Hun samenwerking tijdens de rellen van 2002 kan ook gezien worden als een voortzetting van hun dagelijkse samenwerking tijdens vreedzamer tijden. Lokale alcoholhandelaren, kleine afpersers en eigenaren van gokhallen hebben belangrijke 
redenen om goede contacten te onderhouden met politici. Ze hebben bescherming tegen het ingrijpen van de politie nodig. Aangezien politici enige controle over de politie hebben, kunnen lokale criminelen politieke steun aanwenden om te voorkomen dat de politie ingrijpt bij hun min of meer openlijk uitgeoefende illegale activiteiten. Daarnaast betalen alcoholhandelaren en eigenaars van gokhallen hapta aan zowel politici als aan de politie een stevig maandelijks of wekelijks bedrag om deze van ingrijpen te weerhouden.

Lokale politici hebben verschillende redenen om lokale goondas te helpen bij hun activiteiten. Ten eerste leiden hun illegale activiteiten tot aanzienlijke inkomsten; de hapta die deze lokale criminelen betalen dragen bij aan de financiering van de vaak dure verkiezingscampagnes. Daarnaast zijn lokale goondas ook nuttig vanwege hun muscle power. Politici kunnen deze mensen met een gewelddadig imago inzetten als intimidatiemiddel om zich van de gehoorzaamheid en medewerking van bewoners te verzekeren, bijvoorbeeld om mensen weg te jagen die op grond voor bouwprojecten wonen. Omdat het veel tijd en veel geld kost om een conflict via de rechtbank op te lossen, is het aantrekkelijker om via politici een 'oplossing' te vinden met behulp van muscle power.

Politieofficieren hebben vergelijkbare redenen om goede contacten met politici te onderhouden. In India oefenen politici veel controle uit over de plaatsing en promoties van ambtenaren. Overheidsambtenaren in India worden regelmatig overgeplaatst - dit wordt het transfer system genoemd - en dit geeft politici een zeer effectief instrument om druk uit te oefenen op politieagenten en ambtenaren (De Zwart, 1994; Wade, 1985). De capaciteit van politici om onwillige politieofficieren over te plaatsten naar afgelegen en weinig lucratieve plekken maakt het voor hen moeilijk om de wensen van politici niet in te willigen, zelfs als deze wensen illegaal zijn. Aangezien zelfs leidinggevende politiecommissarissen de steun van politici nodig hebben, kunnen zij hun ondergeschikten niet beschermen tegen politieke inmenging. $\mathrm{Zij}$ geven vaak gehoor aan overplaatsingsverzoeken van politici, zodat ook een lokale politieinspecteur of agent zich gedwongen ziet goede relaties met politici te onderhouden.

Een andere reden voor de vaak innige relaties tussen politici en de politie is dat het onderhouden van relaties geld kan opleveren. Door samen te werken kunnen deze actoren allerlei illegale activiteiten oogluikend toestaan, waar veel geld voor kan worden gevraagd. In de praktijk bieden alle illegale of semi-illegale activiteiten de mogelijkheid om geld te verdienen. Straatverkopers, alcoholverkopers, uitbaters van gokhallen of handelaren die geen belasting willen betalen, betalen allemaal geld aan politici en de handlangers van politici. Dat gebeurt in ruil voor de 'regulering' die hun activiteiten mogelijk maken. Het is niet alleen 
hebzucht, maar ook noodzaak die politiebeambten motiveert om aan rent seeking te doen, want zij hebben vaak flinke sommen geld moeten betalen om hun huidige baan te verkrijgen en die investering moet worden terugverdiend.

De samenwerking tijdens de rellen tussen lokale politici en de activisten van hindoe-nationalistische organisaties, zoals de RSS en de VHP, kan ook gezien worden als een product van het dagelijks functioneren van patronagenetwerken. Deze organisaties zijn in Gujarat zeer succesvol geweest in het verspreidden van antimoslimsentimenten, mede dankzij hun onovertroffen grassroot-netwerk gevormd door duizenden aanhangers. Er zijn goede redenen om te beargumenteren dat de populariteit van deze organisaties is toe te schrijven aan de aantrekkelijkheid van de ideeën die zij uitdragen. De hindoe-nationalistische ideologie lijkt een gevoel van trots en zekerheid te bieden in een tijd dat oude sociale verhoudingen en leefstijlen steeds meer onder druk komen te staan (Basu et al., 1993; Blom Hansen, 1999; Jaffrelot, 2005). Maar de populariteit van deze organisaties kan ook worden toegeschreven aan de capaciteit van de netwerken rond deze organisaties om toegang te verschaffen tot de staat. In Ahmedabad zijn organisaties zoals de VHP en de RSS een onlosmakelijk onderdeel van de patronagenetwerken. Dat biedt zulke organisaties een mogelijkheid om aanhang te winnen. Dit is ook in andere steden en dorpen waargenomen (Blom Hansen, 2001; Banerjee, 2000; Simpson 2006). Het succes van organisaties als de VHP, de RSS en de Bajrang Dal hangt zo samen met hun vermogen om banen, vergunningen, elektriciteitsaansluitingen of connecties met de politie te regelen.

De rol die lokale activisten van hindoe-nationalistische organisaties speelden tijdens de rellen moet daarom ook geïnterpreteerd worden in het licht van het functioneren van lokale patronagenetwerken. Deze actoren zijn op elkaar aangewezen, niet alleen omdat ze een gedeeld belang bij communaal geweld hebben, maar ook omdat ze met elkaar moeten samenwerken om controle over de staat te verwerven.

Een tweede argument voor de relatie tussen communaal geweld en het bemiddelde karakter van de staat in Gujarat is dat het dagelijkse functioneren van politici en buurtleiders hen als tussenpersonen de noodzakelijke autoriteit verleent om spanningen te creëren en geweld te legitimeren. De mensen met toegang tot staatsmiddelen kunnen dankzij hun contacten invloedrijke buurtleiders worden. Zo speelde de structuur van lokale patronagenetwerken een belangrijke rol tijdens de mobilisatie van geweld. 


\section{4. 'Wie de macht heeft, heeft het woord'}

De brand en het daaropvolgende overlijden van 58 mensen in de treinwagon in Godhra kan op verschillende manieren worden geïnterpreteerd. De brand kan een Pakistaans complot zijn geweest, bedoeld om India te destabiliseren; de brand zou het gevolg kunnen zijn van een ruzie tussen passagiers en theeverkopers of de brand zou gewoon veroorzaakt kunnen zijn door een slecht functionerend kookstel in de wagon. Vanwege deze uiteenlopende verklaringen zijn de toespraken van (lokale) leiders een essentieel element in de aanloop tot geweld. Tijdens toespraken en buurtbijeenkomsten kan een incident - zoals de brand in Godhra - een interpretatie krijgen die het uitoefenen van geweld kan helpen legitimeren. De betekenis van een incident moet op een dergelijke manier gemanipuleerd worden dat wij-zij-scheidslijnen worden benadrukt en dat tevens duidelijkheid ontstaat over wie een legitiem doelwit voor vergelding kan zijn. Brass (2003: 33) noemde de mensen die deze taak vervullen conversion specialists. Tambiah (1996: 257) beschreef deze aanloopfase naar etnisch geweld als parochialization, een 'reproduction of a national issues in diverse local places, where it explodes like a cluster bomb in multiple context-bound ways'.

De belangrijke vraag is hier: naar wie wordt geluisterd? Wiens interpretatie van een dergelijk incident wordt overgenomen, van wie komen de geruchten en roddels die geloofd worden? Waarom lukt het sommigen om hun interpretatie te laten prevaleren, terwijl de argumenten van anderen worden genegeerd? Een antwoord op deze vragen ligt in de structuur van de lokale patronagenetwerken, omdat de autoriteit en invloed van lokale leiders ondersteund wordt door hun capaciteit om medebewoners toegang te verschaffen tot de staat. In een buurt als Gomtipur waar bewoners moeilijk toegang tot staatsinstellingen kunnen verkrijgen zonder de hulp van politieke tussenpersonen, staan invloedrijke tussenpersonen in hoog aanzien. Deze lokale leiders worden beschreven als personen die 'invloed op mensen hebben' (emne prabhav chhe) die hen in staat stelt om de meningen en het stemgedrag van hun buren te beïnvloeden. Het lokale leiderschap is dan ook sterk gepolitiseerd. Er zijn slechts weinig stanik netas ('buurtleiders') in een buurt als Gomtipur die niet op de een of andere manier geaffilieerd zijn aan politici. Dit gepolitiseerde karakter van het lokale leiderschap is belangrijk om te begrijpen waarom politici en leiders van hindoe-nationalistische organisaties erin slaagden om mensenmenigten te mobiliseren voor geweld.

Dat succes is echter ook aan andere factoren te wijten. Geweld heeft ook een bepaalde inherente aantrekkelijkheid. Geweld kan immers een manier zijn om gevoelens van frustratie of machteloosheid te ontladen en geweld kan plezier en een gevoel van superioriteit opleveren (vergelijk Nussbaum, 2007; Verkaaik, 2003). Maar dat wil niet zeggen dat 
mensen met deze behoeftes altijd even gemakkelijk tot geweld kunnen overgaan (zie Collins, 2008). Deze behoeftes kunnen pas echt uitgeleefd worden als iemand met autoriteit dit gedrag goedkeurt. Dat maakt de structuur van lokaal leiderschap essentieel om te begrijpen hoe communaal geweld zich door een stad of dorp kan verspreiden.

De afhankelijkheid van bewoners in Gomtipur van politici als Jitu Vaghela verschafte hem de geloofwaardigheid en autoriteit om tegenstellingen tussen hindoes en moslims te benadrukken en, uiteindelijk, het geweld te legitimeren. Zijn contacten met de buitenwereld en zijn vlotheid in de omgang met de overheid stelde hem in staat om een cruciale rol te spelen tijdens de rellen. Deze invloed was voor een groot gedeelte gebaseerd op zijn bewezen capaciteit om dagelijkse problemen van bewoners op te lossen. Zoals een Hindi-gezegde luidt: jiska joor hai, uski baat hai - wie de macht heeft, heeft het woord.

Bovendien levert deze capaciteit een nuttig netwerk van aanhangers op, aanhangers die gebruikt kunnen worden om geruchten te verspreiden en mensen te mobiliseren. En wie dan toch niet wil luisteren, kan geïntimideerd worden. De goede contacten tussen politici en de politie werken vaak als een afschrikking voor mensen die tijdens de rellen een andere mening zouden willen laten horen. Zoals een informant vertelde: 'Ik woon in een hindoe-buurt, ok? Dus als ik gewone mensen zeg "doe niet mee aan de rellen," dan zou ik een groot risico hebben gelopen. Dit keer stonden de regering en de politie aan de kant van de hindoes, dus niemand durfde openlijk te praten.'

\section{De voordelen van geweld}

Aanzetten tot geweld kan ten slotte ook begrepen worden door te kijken naar hoe dit etnisch geweld allerlei actoren helpt om toegang tot de staat te verwerven of de bestaande band te versterken. De wederzijdse afhankelijkheden tussen goonda's, party workers, politieagenten en politici zijn relevant om te begrijpen waarom deze mensen een actieve bijdrage konden leveren aan het organiseren en plegen van geweld. Een paar weken na het begin van de gewelddadigheden in Gujarat verschenen in de Indiase media geruchten over een geheime ontmoeting die premier Narendra Modi georganiseerd zou hebben. Een minister getuigde onder voorwaarde van anonimiteit dat tijdens deze bijeenkomst Modi de politie opgedragen zou hebben om mensen 'hun woede te laten uiten'. De aanwezigen werd opgedragen om activisten van hindoe-nationalistische organisaties niets in de weg te leggen. Een recente undercoverreportage van het weekblad Tehelka ondersteunde deze claim (in geheim opgenomen interviews getuigden verschillende deelnemers aan de rellen dat Modi de politie had opgedragen om 'mee te werken'. 'De politie stond 
vlak voor ons en ze konden alles zien wat er gebeurde. Maar ze hielden hun mond en ogen gesloten. [...] Als ze ons hadden willen stoppen - ze waren met 50 man - dan hadden ze ons kunnen stoppen. [...] We kregen goede steun van de politie, dankzij Narendrabhai [Modi].'3 Zulke beweringen sluiten aan bij getuigenissen van slachtoffers die de politie om hulp hadden gevraagd. Die kregen als antwoord 'Vandaag zijn we van boven bevolen dat jullie niet gered mogen worden' en 'Ze hebben 24 uur gekregen om jullie te doden' (CCT, 2002: 37; HRW, 2002: 5).

Deze gehoorzaamheid van de politie moet begrepen worden in het licht van de dagelijkse interactie tussen politici en de politie om lokale problemen op te lossen en om hapta te verdienen met het oogluikend toestaan van illegale activiteiten. Tegelijkertijd hebben politieagenten politici nodig om de goede overplaatsing of een goede promotie te regelen, of om een zogenaamde punishment posting te voorkomen. Het is politieagenten er dan ook alles aan gelegen om een goede relatie met lokale politici te behouden, want een ruzie met een invloedrijke politicus kan leiden tot een verlies van inkomsten en een onaangename overplaatsing. Een van de belangrijkste politie-inspecteurs in Gomtipur beschreef de invloed van politici als volgt: 'In tien tot vijftien procent van de gevallen [van arrestaties] moeten we luisteren naar de wil van politici. Politici bepalen onze postings en onze transfers, we zijn van hen afhankelijk. Dus moeten we naar hun wensen luisteren. Soms doet me dit verdriet, als we iets niet kunnen doen wat rechtvaardig zou zijn.'

De controle van politici over de carrièreperspectieven van politiebeambten ontmoedigt hen om in te grijpen tijdens rellen, terwijl medewerking met politici zich kan vertalen in betere posities en meer inkomen. De transfers en promoties van de politie tijdens en na de rellen illustreren dit. Over het algemeen zijn de politie-inspecteurs die het geweld ondersteunden achteraf gepromoveerd, terwijl een groot aantal van de moedige politiefunctionarissen die poogden het geweld te stoppen zijn overgeplaatst naar banen die worden gezien als punishment postings. ${ }^{4}$

Deze politieke pressie op de politie illustreert de relatie tussen Gujarats communaal geweld en de controle die politici uitoefenen over het dagelijks functioneren van staatsinstellingen. In de situatie waar gewone burgers zich wenden tot politici om toegang te krijgen tot de staat hebben zij een direct belang bij het controleren van de transfers van overheidsfunctionarissen, omdat hun politieke carrière afhangt van hun vermogen om het functioneren van deze functionarissen te beïnvloeden. Hun inmenging in het dagelijks functioneren van de politie heeft het politiekorps niet alleen gepolitiseerd, maar ook het vermogen van individuele politieagenten om de wet te handhaven ondermijnd. Het gevolg is dat de politie niet in staat en niet bereid is om het aanzetten tot geweld te stoppen. 
De rol die lokale partijleden en aanhangers van hindoe-nationalistische organisaties zoals de RSS en de VHP speelden tijdens de rellen, kan op een vergelijkbare manier worden geïnterpreteerd. De promotie van een partijlid binnen de organisatie hangt niet alleen af van de hoeveelheid werk die hij of zij verzet heeft, maar ook van de steun van invloedrijke politieke leiders. In dit licht gaat de uitruil van gunsten die plaatsvindt tijdens 'normale' tijden gewoon door tijdens rellen. De praktische bijdrage van lokale 'werkers' aan het geweld, zoals het verspreiden van wapens, het regelen van trucks om mensen te vervoeren, het mobiliseren van mensen, het uitdelen van voedselhulp en dergelijke helpt hen om hun relatie met invloedrijke leiders te versterken. Met hun activiteiten tijdens rellen kunnen hindoe-nationalistische aanhangers en partijleden zich verzekeren van de steun van belangrijke politici.

Hiermee wil ik niet suggereren dat deze lokale activisten alleen maar deelnamen aan het geweld om hun leiders te plezieren. Velen van hen zullen echt overtuigd zijn geweest dat moslims een dergelijk gruwelijke behandeling verdienden. Sommigen zullen hebben genoten van de spanning en intensiteit van de rellen, anderen zullen ook hebben gehandeld uit een diepgewortelde angst voor moslims. Maar tegelijkertijd zouden politici en leiders van hindoe-nationalistische organisaties niet hebben kunnen rekenen op de medewerking van lokale netwerken van sympathisanten als zij hun aanhang niet zouden kunnen helpen met toegang tot staatsmiddelen. Deze organisaties en leiders kunnen rekenen op de loyaliteit van grote groepen aanhangers, niet alleen vanwege de populariteit van hun ideologie, maar ook vanwege hun vermogen om hun aanhangers met status en macht te belonen.

Ook de samenwerking tussen lokale criminelen en politici tijdens de rellen kan op een dergelijke manier geïnterpreteerd worden. Omdat goondas de steun van politici nodig hebben om hun activiteiten gaande te houden, kunnen zij niet eenvoudigweg de verzoeken van politici tijdens rellen naast zich neerleggen. Als hij echter de mensenmenigten aanvoert tijdens de plundering en brandschatting, dan kan hij de steun verwerven van de mensen die hij nodig heeft om zijn winstgevende activiteiten voort te zetten. In de woorden van een informant: 'tijdens rellen worden zij [goondas] leiders. Als ze niet meedoen, dan verpesten ze hun imago.' In normale tijden zijn deze mensen betrokken bij dadagiri ['illegale activiteiten']. Dus een goonda denkt dat, als hij geen leiderschap op zich neemt tijdens de rellen, dat hem dat schade zal berokkenen in normale tijden. Mensen zullen zeggen [als hij wel meedoet aan de rellen] 'Jij hebt ons geholpen, dus nu kan je doorgaan met je dadagiri.' Zo is communaal geweld eigenlijk het onderhouden van relaties en biedt deelname van goondas aan de rellen hen de mogelijkheid om belangrijke contacten en bronnen van inkomen zeker te stellen. 


\section{Conclusie}

In het voorgaande heb ik het geweld tussen hindoes en moslims dat in 2002 plaatsvond in verband gebracht met manier waarop politici en hun aanhangers bemiddelen tussen burgers en staat. De afhankelijkheid van burgers van deze bemiddeling ligt aan de basis van de capaciteit van lokale (politieke) actoren om tot geweld op te roepen. Op deze manier kan Gujarats communale geweld gezien worden als een product van de manier waarop de staat in Gujarat is ingebed in de maatschappij. De lokale netwerken die het geweld mogelijk hebben gemaakt zijn het gevolg van de moeilijkheden die gewone burgers ondervinden om toegang te verkrijgen tot de staat. De netwerken van actoren die het geweld organiseren en plegen overlappen grotendeels met de patronagenetwerken die burgers gebruiken om toegang te verkrijgen tot die staat. Het dagelijkse functioneren van deze patronagenetwerken geeft vorm aan de mobilisering die plaatsvond tijdens rellen waarbij de positie van deze actoren in de patronagenetwerken veel verklaart. Etnisch geweld is een instrument in de competitie om controle over de staatsmiddelen te verkrijgen. Het plegen van communaal geweld komt neer op het onderhouden en bevestigen van dergelijke belangrijke relaties.

\section{Noten}

Deze beschrijving van het geweld in Gomtipur is gebaseerd op interviews, op transcripties van aangiftes gedaan bij de politie (zgn. FIR's) en rapporten van onderzoekscommissies (Communalism Combat (CC) 2002 (39)), Concerned Citizens Tribunal (CCT) 2002 (52-61), HRW 2002 (25-26).

Voor bespreking van hoe getuigen zijn gemanipuleerd en geïntimideerd, zie HRW 2003. Amnesty International (2003) heeft gedocumenteerd hoe de rechtspraak in Gujarat vaak bevooroordeeld is tegen moslims.

3 'Their Eyes and Mouth were shut', Tehelka 3-11-2007.

4 Voor een overzicht van de politiefunctionarissen die beloond en gestraft werden met promoties en demoties na de rellen, zie CC, 2002 (194-200); CCT; 2002 (9091); 'Carrot \& Stick', Tehelka 12-03-2005 en 'CM 'punishes' officers who didn’t toe line, rewards others', Times of India 25-3-2002.

\section{Literatuur}

Amnesty International (2003). Abuse of the Law in Gujarat (Muslims detained illegally in Ahmedabad). http/web.amnesty.org/library/Index/ ENGASA200292003 (accessed 03-08-07).

Banerjee, S. (2000). Warriors in Politics. Hindu Nationalism, Violence, and the Shiv Sena in India. Boulder: Westview Press.

Basu, T., P. Datta, S. Sarkar, T. Sarkar en S. Sen (1993). Khaki Shorts and Saffron Flags. A critique of the Hindu Right. New Delhi: Orient Longman.

Berenschot, W. (n.d.). Local Politics and the Everyday Mediation of the State in India. Amsterdam: unpublished manuscript. 
Berenschot, W. (2009). Riot Politics. Communal Violence and State-Society Mediation in Gujarat, India. Amsterdam: Proefschrift Universiteit van Amsterdam.

Blom Hansen, T. (1999). The saffron wave, democracy and Hindu-nationalism in modern India. Princeton: Princeton University Press.

Blom Hansen, T. (2001). Wages of Violence. Naming and Identity in Postcolonial Bombay. Princeton: Princeton University Press.

Blom Hansen, T. (2005). Sovereigns Beyond the State. On Legality and Public Authority in India. In R. Kaur (ed.), Religion, Violence and Political Mobilisation in south Asia. New Delhi: Sage Publications.

Bourdieu, P. (1991). Political Representation. Elements for a Theory of the Political Field. In Language and Symbolic Power. Cambridge: Polity Press. Bourdieu, P. (1999). Rethinking the State. Genesis and Structure of the Bureaucratic Field. In G. Steinmetz (ed.), State/Culture. State-formation after the Cultural Turn. New York: Cornell University Press.

Bourdieu, P. en L.J.D. Wacquant (1992). An Invitation to Reflexive Sociology. Chicago: Polity Press.

Brass, P. (1996). Riots and Pogroms. London: Macmillan Press.

Brass, P. (1997). Theft of an Idol. Text and Context in the Representation of Collective Violence. Princeton: Princeton University Press.

Brass, P. (2003). The Production of Hindu-Muslim violence in contemporary India. Washington: University of Washington Press.

Chandra, K. (2004). Why Ethnic Parties Succeed? Patronage and Ethnic Head Counts in India. Cambridge: Cambridge University Press.

Collins, R. (2008). Violence. A micro-sociological Theory. Princeton: Princeton University Press.

Concerned Citizens Tribunal (CCT) (2002). Crime against humanity, Vol. 1 and 2. Mumbai: Citizens for Justice and Peace.

Engineer, A.A. (1989). Communalism and Communal Violence in India. New Delhi: Ajanta Publications.

Engineer, A.A. (1995). Lifting the Veil. Communal Violence and Communal Harmony in Contemporary India. Hyderabad: Sangam Books.

Fuller, C.J. en J. Harris (2001). For an Anthropology of the Modern Indian State. In C.J. Fuller en V. Béné, The Everyday State \& Society in Modern India. London: Hurst \& Co.

Gupta, A. (1995). Blurred boundaries, the discourse of corruption, the culture of politics, and the imagined state. American Ethnologist, 22, 375-402.

Harriss-White, B. (2003). India Working. Essays on Society and Economy. Cambridge: Cambridge University Press.

Horowitz, D. (1985). Ethnic groups in conflict. Berkeley: University of California Press.

Horowitz, D. (2002). The deadly ethnic Riot. New Delhi: Oxford University Press. 
Human Rights Watch (2002). 'We have no orders to save you'. State Complicity and Participation in Communal Violence in Gujarat. www.hrw.org (accessed 31-07-07).

Human Rights Watch (2003). Compounding Injustice. The Government's Failure to Redress Massacres in Gujarat. www.hrw.org (accessed 3-8-07).

Jaffrelot, C. (2003). Communal Riots in Gujarat. The State at Risk. Heidelberg Papers in South Asian and Comparative Politics, Vol. 17.

Jaffrelot, C. (2005). The Sangh Parivar (a Reader). New Delhi: Oxford University Press.

Migdal, J. (2001). State in Society. Studying how states and societies transform and constitute one another. Cambridge: Cambridge University Press.

Nussbaum, M. (2007). The Clash within Democracy. Religious Violence, and India's Future. Cambridge: Belknap Press.

People's Union for Democratic Rights (PUDR). (2002). Maaro! Kaapo! Baalo. New Delhi: State, society and Communalism in Gujarat.

Roniger, L. (1994). The comparative Study of clientelism and the Changing Nature of Civil society in the Contemporary World. In L. Roniger en A. Günes-Ayata, Democracy, Clientelism, and Civil Society. Boulder: Lynne Rienner Publishers.

Setalvad, T. en J. Anand (2002). Genocide Gujarat 2002. Mumbai: Communalism Combat (CC).

Scott, J. (1972). Patron-client Politics and Political change in Southeast Asia. The American Political Science Review, 66, 91-113.

Simpson, E. (2006). The State of Gujarat and the Men without Souls. Critique of Anthropology, 26, 3, 331-348.

Sundar, N. (2002). A Licence to Kill. Patterns of Violence in Gujarat. In S. Varadarajan, Gujarat, the Making of a Tragedy. New Delhi: Penguin Books.

Tambiah, S. (1996). Leveling crowds. Ethnonationalist conflicts and collective violence in South Asia. Berkeley: University of California Press.

Varadarajan, S. (2002). Gujarat, the Making of a Tragedy. New Delhi: Penguin Books.

Varshney, A. (2002). Ethnic Conflict and Civic Life. Hindus and Muslims in India. New Haven \& London: Yale University Press.

Verkaaik, O. (2003). Fun and violence. Ethnocide and the effervescence of collective agression. Social Anthropology, 11, 1, 3-22.

Wade, R. (1985). The Market for Public Office. Why the Indian State is not better at Development. World Development, 13, 4, 467-497.

Wilkinson, S.L. (2004). Votes and violence: electoral competition and ethnic riots in India. Cambridge: Cambridge University Press.

Women's Panel (2002). How has the Gujarat Massacre affected Minority Women? The Survivors Speak. http//cac.ektaonline.org/resources/ reports/womensreport.htm (accessed 31-07-07). 
Zwart, F. de (1994). The Bureaucratic Merry-go-round. Amsterdam: Amsterdam University Press.

130 


\title{
Etnisch geweld op Ambon
}

\author{
Gerry van Klinken
}

\section{Het begin}

Ambon, 20 januari 1999, de eerste dag van de burgeroorlog tussen christenen en moslims die drie jaar lang zou woeden.

Human Rights Watch interviewde een jongen, Hamid (niet zijn echte naam). Hij zei 18 te zijn maar zag er jonger uit. Een Butonees van de Gunung Nona wijk in [de stad] Ambon. Op 20 januari 1999 was hij thuis met zijn moeder en een zusje. Het meisje zat in de 3de klas van de basisschool. Zij ging naar buiten om te plassen. Plotseling zag ze een bende mensen met rode halsdoeken over mond en neus zo dat alleen hun ogen te zien waren. Allen waren gewapend met messen, bommen en pijlen. Ze schoten zijn zusje met een pijl die haar in de borst trof. Zij gilde voor haar moeder, maar voordat iemand haar kon antwoorden had de bende haar met een hakmes in elkaar geslagen. Ze stopten haar lichaampje in een zak en knoopten die dicht. Hamid stond ongeveer 30 meter verderop. Toen zag hij drie mensen die benzine in zijn huis goten en het in brand staken. Zo snel als hij kon rende hij naar de Al Fatah moskee, maar onderweg moest hij langs een menigte christenen. Die vroegen hem waar hij vandaan kwam, en hij zei, “Tenggara", het zuidoosten, omdat de meeste christelijke families uit die buurt van zuidoost-Molukken kwamen. Hij zei ook dat zijn naam Albertus was, een duidelijk christelijke naam. Zij lieten hem voorbij. Toen hij bij de moskee kwam, kocht hij een liter benzine. Hij zei dat hij een kerk wilde afbranden, omdat zijn eigen huis afgebrand was. (Human Rights Watch, 1999) 
De gevechten in de straten van Ambon, een stad met een bevolking van 180.000 inwoners, en in andere plaatsen in het zuidelijke gedeelte van de provincie Molukken eisten uiteindelijk 2.000 levens. Daarnaast was er nog eens een kwart miljoen ontheemden. Een vredesverdrag in februari 2002 bracht de gevechten langzaam tot een einde. In het noordelijke gedeelte van dezelfde provincie brak eind 1999 ook collectief geweld uit, waarbij 2.800 doden zouden vallen. In Midden-Sulawesi ontvlamde eveneens een lokale burgeroorlog tussen christenen en moslims. In twee provincies van Kalimantan werden in ongeveer dezelfde periode eenzijdige etnische zuiveringsacties ondernomen tegen een onpopulaire groep immigranten die oorspronkelijk afkomstig waren van Madura. Deze conflicten sleepten zich weken of jaren voort met afwisselende fases van grof geweld en onrustige kalmte. Ze bestreken elk een breed gebied. Daarnaast deden zich een aantal dodelijke rellen voor van korte duur en plaatselijke omvang, vaak gericht tegen Chinezen. Separatistisch geweld in Atjeh, West-Irian en Oost-Timor laaide ook op in dezelfde periode. Een conservatieve schatting van het totale aantal komt tot 19.000 doden. Meer dan de helft hiervan viel in langdurig communaal (etnisch en religieus) geweld in plaatsen waar dit tot dan toe ongehoord was.

De uitbarstingen van geweld in zoveel regio's van Indonesië vonden plaats rondom het einde van het regime van Soeharto, op 21 mei 1998. Onder het strenge bewind van deze oud-generaal had de economie zich gedurende 32 jaar sterk ontwikkeld. Een nieuwe middenklasse was ontstaan met haar kenmerkende waarden en met een nadruk op consumeren en vrijheid. De nieuwe middenklasse was sterk vertegenwoordigd in een steeds grotere overheid - vaak als onderwijzers en verplegers. De studentenbetogers in 1998 met hun stijgende verwachtingen kwamen uit deze middenklasse voort. In tegenstelling tot de Europese ervaring van stijgende secularisatie dreef de stedelijke godsdienstbeleving in Indonesië naar een steeds rechtlijniger orthodoxie. Modernisatie bracht ook ellende, zoals onderdrukking van arbeiders, marginalisatie van keuterboeren en indigenous people, en milieuvervuiling. Grootschalige transmigratie van mensen uit het overbevolkte centrale eiland Java naar de buiteneilanden, gepaard met ontbossing en de aanleg van nieuwe wegen, versnelde daar het tempo van sociale verandering. De bijna routineachtige schendingen van de mensenrechten onder marginale groepen, en het militaristische centralisme van Soeharto, stookten ontevredenheid in regio's buiten Java. De spanningen van het moderniseringsproces produceerden zowel hoop als frustratie, het laatste soms uitte zich soms in onverdraagzaamheid tegenover minderheden of andersdenkenden.

$\mathrm{Na} 1991$ begon de inwerking van de Nieuwe Orde iets af te zwakken. Actieve militaire officieren werden geleidelijk teruggetrokken uit bestuursposities in de provincies. De keuze in de boekwinkel werd breder 
en internet begon de censuur aan te vreten. Ook werd een beweging voor milieudefensie opgericht. De verkiezingen bleven echter gemanipuleerd door Soeharto's staatspartij Golkar. Het regime kwam uiteindelijk ten val door een totaal onverwachte economische crisis. Indonesië werd het hardst getroffen door de Aziatische crisis van eind 1997. De tot dan toe welvarende middenklasse veranderde haar passieve steun voor Soeharto in plotselinge hoon voor een oude man. Te midden van grote demonstraties die in Jakarta en andere steden begin mei 1998 ontaardden in moord- en brandstichting met meer dan duizend slachtoffers, besloot Soeharto de macht over te dragen aan zijn vice-president B.J. Habibie.

Habibie was een liberaal maar zwakke overgangsfiguur aan het einde van een onpopulair regime. Als een soort Gorbachov had hij zijn volk weinig te bieden buiten beloftes voor verbetering. Politieke gevangenen werden bevrijd, censuur en het verbod op vergaderingen opgeheven, er kwamen vrije verkiezingen, de provincies kregen meer zelfbestuur de lijst van hervormingen was lang. De drang naar verandering was zo groot dat de gevestigde elites zich voor een paar jaar angstig in een revolutionaire sfeer waanden. Alles leek op de schop te gaan. De dwang van onderaf was inderdaad opmerkelijk. Jongeren met een opleiding, hun toekomstverwachtingen gefrustreerd door de crisis, namen een vijandelijke houding tegenover de vermeende schuldigen aan, zoals de overheid, maar ook groepen in de samenleving die hen dwarszaten. Grote delen van de gewone bevolking die ook was getroffen, stelden zich open voor deze mobilisatie van onvrede. Dit alles zette enorme druk op de nationale elites die toch al geschokt waren door het aftreden van hun beschermheer. De dreiging van een grondige vervanging van de gevestigde elites, samen met een geschiedenis van onderling wantrouwen die lang was gestimuleerd door de patriarchale Soeharto, bemoeilijkte hun samenwerking.

Politiek gezien het meest gevoelig lag de positie van het leger. Soeharto's steunpilaar moest een vloed van kritiek incasseren voor zijn criminele gedrag in het verleden. Een belangrijk deel van Habibies hervormingen was het invoeren van een scheiding tussen politie en leger. Voorheen het 'kleine broertje' binnen de strijdkrachten werd de politie nu verantwoordelijk voor de binnenlandse veiligheid, terwijl het leger zich uitsluitend met buitenlandse bedreigingen zou gaan bezighouden. Legervertegenwoordigers werden geleidelijk uit het parlement en bestuur verwijderd. Maar de vrees voor een militaire reactie leek niet overdreven. Zouden zij op betogers schieten, zoals op het Tianmen-plein, of zelfs een coup plegen, zoals in Thailand? De wereld was echter veranderd sinds 1965 en het leger besloot geen risico's te nemen. Wel nam het uiteraard een afwachtende houding aan toen het communaal geweld losbarstte op Ambon en andere plaatsen. De politie was te onervaren om het geweld 
effectief te beheersen, en nog minder bereid dan het leger burgerslachtoffers te maken. Bovendien waren veel plaatselijke politie-eenheden verwikkeld in conflicten met legereenheden over de controle van extrabudgettaire bronnen van inkomsten, zoals illegale houtkap, het mijnwezen, transport, drugs of prostitutie. De politie stond praktisch machteloos.

\section{Het gezagsvacuüm}

Het gezagsvacuüm in het Indonesië van 1998 wordt door wetenschappers wel een 'open kansstructuur' genoemd. De deuren van een zwakke staat staan open voor protest van zowel gevestigde elites als dissidenten. Maar tegelijk heeft zij weinig capaciteit om werkelijke veranderingen door te voeren. Toen de deuren nog wijder openzwaaiden in 1998 signaleerden velen de kans hun eigen positie te verbeteren, desnoods op onrechtmatige wijze. Een dergelijk gezagsvacuüm ontstond ook op Ambon rondom januari 1999. De moord op Hamids zus gebeurde acht maanden na de val van president Soeharto, vijf maanden vóór de verkiezingen van nieuwe nationale en plaatselijke politici, te midden van een luidruchtige vernieuwingsbeweging, door Indonesiërs reformasi genoemd, en zonder duidelijk tegenwicht van de veiligheidsdiensten.

Het grote inzicht van Tilly, die samen met zijn studenten het begrip 'kansstructuur' ontwikkelde, was dat de organisatie centraal moet staan in de analyse van geweld. Hij stelde (1978) dat het gebruik van geweld een zekere rationaliteit bezit. Historisch gezien krijgen mensen maar zelden de organisatorische middelen in handen om daadwerkelijk een revolutie te ontketenen. Een studie van deze organisaties kan van meer praktisch belang zijn dan een studie van frustratie. Social movements theory, later toegespitst op gewelddadige politiek en contentious politics genoemd (McAdam, Tarrow en Tilly, 2001) bleek zeer vruchtbaar in de verheldering van dynamiek van een conflict. De analyse geeft inzicht in het ontstaan van dynamische processen in een conflict die de woedende krachten van een groot aantal gewone Hamids bundelen en hen de straat op jagen. Velerlei permanente of kortstondige organisaties spelen daarin een centrale rol. Dit te begrijpen, en wel zonder het verhaal van Hamid in grote abstracties te verliezen, is aanzienlijke wetenschappelijke winst.

Studies over het geweld in Indonesië rondom 1998 die geen gebruikmaakten van een social movements-benadering misten dan ook een belangrijke mogelijkheid om te begrijpen waarom een gewone jongen als Hamid met het geweld meedeed. Die studies waren te algemeen en boden evenmin inzicht historische ontwikkelingen. De pers zag op Ambon een uitbarsting van krankzinnigheid (amok), net zoals de pers amok had geconstateerd in de bloedige Indonesische pogrom tegen ver- 
meende communisten in 1965-1966 (Tanter, 2002). Sommige commentatoren spraken in stereotypen als ze het over een natuurlijk-primordiale haat tussen rivaliserende levensopvattingen in een ontwikkelingsland hadden. Er werd in geologische en meteorologische beeldspraak gesproken van een losbarstende 'vulkaan', van 'een storm van geweld' die door het land trok. Dit was een geschiedenis zonder daders. Eén reden waarom deze verklaringen niettemin veel herhaald worden is dat een geschiedenis zonder daders als moreel rookgordijn dient voor mensen met bloed aan hun handen.

Een in academische kring meer gangbare analyse zoekt naar de maatschappelijke oorzaken van de duidelijke frustratie onder de deelnemers. Wetenschappers berekenden correlaties tussen geweldsincidenten en economische ongelijkheden, godsdienstige verscheidenheid en kindersterfte als aanwijzer van sociale ellende. Toch zijn de correlaties voor Ambon en andere plaatsen van communaal geweld en maatschappelijke factoren in Indonesië nooit erg hoog. Dat komt omdat ze op een statisch beeld van de maatschappij berusten. De benadering had dan ook niets te zeggen over het overduidelijke feit dat het geweld losbrak op een bepaald moment, namelijk bij de aanvang van een politieke overgang naar een nieuw regime.

Een nog beter doordachte variant van geschiedenis zonder daders benadrukte het ongewilde karakter van etnisch geweld. Soms werd dit geformuleerd als het 'beveiligingsdilemma'. Oorlogen ontstaan niet omdat mensen dat per se willen, maar omdat zij, de bedoelingen van hun tegenstander niet kennend, uit voorzorg hun eigen beveiliging mobiliseren. Ook dit is een aansprekende verklaring. De geschiedenis is vaak ongewild. Maar geweld blijft mensenwerk en mensen hebben altijd keuzes.

De politieke mobilisatie rondom 1998 kon alleen plaatsvinden door middel van een organisatie en dus door leiderschap. Alleen elites, mogelijk met hun eigen belangen, overschrijden door hun brede contacten de grenzen die gewone mensen afperken in hun enge kring van familie of woonwijk. De Al-Fatah moskee waarheen Hamid die avond vluchtte was middelpunt van precies een dergelijke organisatie met leiderschap. Aan de kant van christenen speelde de Maranatha kerk al vroeg een vergelijkbare rol. In beide centrale gebouwen, slechts een kilometer van elkaar gelegen, werden milities samengesteld, communicatiemiddelen geïnstalleerd, preken verkondigd, geld ingezameld, nieuwsberichten met het karakter van propaganda geproduceerd, vluchtelingen verzorgd en medische zorg verleend.

De christenen vormen in Indonesië een kleine minderheid van rond de tien procent, van wie protestanten ongeveer tweederde uitmaken. Maar in sommige plaatsen - oude zendingsvelden - bereiken christenen 
lokaal een meerderheid. De stad Ambon is een dergelijke plaats. In de provincie Maluku in zijn geheel waren christenen nog goed voor vijftig procent in 1971, maar hoofdzakelijk door immigratie van moslims was dat twintig jaar later gedaald naar 43 procent. De verhouding tussen de twee godsdiensten leek op een balans die langzaam richting de islam verschoof.

De milities in de Molukse burgeroorlog waren op godsdienstige basis georganiseerd. Vanuit een organisatorisch oogpunt stond de christelijke kant naar verhouding sterker dan de islamitische. De Molukse Protestantse Kerk (Gereja Protestan Maluku, GPM) is verreweg de grootste nietgouvernementele organisatie in de provincie. De GPM is hiërarchisch georganiseerd, net als de lokale overheid. De jeugdbeweging van de kerk, de Angkatan Muda Gereja Protestant Maluku (AM-GPM), heeft honderden geaffilieerde groepen. Alle protestantse jongeren op Ambon zijn grootgebracht in een hoogst formele godsdienst via een voortdurende stroom van activiteiten. Zelfs in een wijk of dorp zonder enig ander vertier is er bijna elke avond wel een kerkactiviteit. Het is onmogelijk om aanzien te genieten in de protestantse Ambonese samenleving zonder actieve deelname aan het kerkelijk leven. Alle protestantse prominenten op Ambon zijn dan ook tegelijk leiders in de kerk. Tijdens de oor$\log$ onderhield een goed uitgerust commandocentrum in de Maranatha kerk met de naam Communicatiehulp (Bantuan Komunikasi, Bankom) via handy talky-radio's intensief contact met jonge dominees aan het hoofd van alle kerkelijke jeugdorganisaties. Mocht er iets gebeuren op één front, dan werden onmiddellijk hulptroepen van elders gestuurd. De productie van wapens en waarschijnlijk de financiering (hierover is weinig bekend) was eveneens aan protestantse kant goed georganiseerd.

De organisatorische eensgezindheid van de protestantse kerk had ook een politieke kant. Hoewel de kerk officieel geen politieke standpunten innam, steunden bijna alle protestanten in 1999 maar één partij en dat was de PDI-P van Megawati Soekarnoputri. De PDI-P is op zich geen godsdienstige partij, maar op Ambon werd het bestuur volledig bezet door protestanten. Deze plaatselijke afwijking had zijn wortels in de geschiedenis. In de liberale periode voorafgaande aan de Nieuwe Orde stemden bijna alle protestanten in Maluku op de protestantse partij Parkindo. Soeharto echter stond maar drie politieke partijen toe, alle onder streng militair toezicht. Hij bereikte dat doel door protestantse en katholieke partijen te dwingen samen te gaan met populistisch-nationalistische partijen in één partij, de PDI, voorloper van de huidige PDI-P. Op Ambon was de PDI tijdens de Nieuwe Orde dus in feite gewoon de Parkindo in een ander jasje. PDI-P voorzitster Megawati, onder Soeharto een oppositiefiguur, was dan ook uitzinnig geliefd op Ambon toen zij zich opwierp als de vervanger voor Habibie. Zij stelde een protestantse Ambonees aan 
als secretaris-generaal van haar partij. Vlak voor de verkiezing van 7 juni 1999, de eerste democratische verkiezing in meer dan veertig jaar, werd de PDI-P dan ook vanaf alle preekstoelen op Ambon aangeprezen.

De islam op Ambon is in alle opzichten anders. Zij kent geen 'kerk' 137 als centrale organisatie. Elke moskee organiseert zichzelf. Islamitische kloosterscholen (pesantren) die op Java een belangrijke rol spelen bij de socialisatie van de jeugd, bestaan niet op Ambon. Een verscheidenheid aan islamitische milities in 1999 opereerde grotendeels onafhankelijk van elkaar. Het gebrek aan organisatorische discipline kwam de moslims duur te staan. De islam had wel een coördinerend instituut in de Al-Fatah moskee, maar daar werd voortdurend over beleid getwist. Bijvoorbeeld over de kwestie 'wel of niet onderhandelen met christenen' waren de meningen zo verdeeld dat een aantal huizen van gematigde moslimleiders platgebrand werden door onverzettelijke medemoslims.

Ook politiek waren de moslims allerminst eensgezind. Waar alle protestanten één partij steunden, concurreerden een aantal islamitische partijen voor de stem van de moslim. De versnipperde partijstructuur was geen wezenlijke bedreiging voor de PDI-P. Onder hoogopgeleide moslims bestond wel één redelijk invloedrijke lobbyorganisatie, de ICMI. Deze was rond 1990 door Soeharto zelf opgezet en werd door Habibie geleid. Soeharto zag de organisatie als steun voor zijn eigen belangen tegen een jongere generaties van legerofficiers, maar het werd ook een belangrijke patronageorganisatie, vooral binnen de bureaucratie. Op Ambon was een aantal hooggeplaatste islamitische bestuursambtenaars actief in de ICMI. De organisatie bood de belofte van emancipatie voor moslims die lang achter waren gesteld bij de verwerving van banen bij de overheid. De ICMI was echter niet ingebed in de moskeeën op een wijze die met de PDI-P kon worden vergeleken. Kortom, organisatorisch gezien liepen de commandolijnen van de respectievelijke strijdkrachten op Ambon parallel aan die van kerk en moskee, en tegelijkertijd parallel aan die van de plaatselijke politiek. Daarbij was er aan de kant van de christenen sprake van effectieve discipline, terwijl onder de moslims verdeeldheid heerste.

De benadering van geweld vanuit het gezichtspunt van mobilisatie heeft mechanismen blootgelegd die anders onmogelijk aan het licht zouden zijn gekomen. Een gedetailleerdere analyse dan hier mogelijk is laat bijvoorbeeld zien hoe een klein incident heel gemakkelijk kon escaleren tot een ware burgeroorlog; hoe gewone mensen hun angst of onverschilligheid prijsgaven en meededen met een gevaarlijke actie op straat en hoe leidinggevende figuren die elkaar jarenlang kenden plotseling polariseerden en tegenover elkaar kwamen te staan. Dit alles gebeurde op Kalimantan, op Midden-Sulawesi, Noord-Molukken, en ook op Ambon. Een van de belangrijkste conclusies van deze analyses is dat 
het geweld op Ambon niet direct vanuit Jakarta was aangestoken, zoals tot op de dag van vandaag vaak wordt beweerd. Jakarta had er als hoofdstad uiteraard mee te maken, maar het conflict begon op Ambon zelf en putte zijn energie voortdurend uit plaatselijke bronnen.

Die energie kwam voort uit de democratische concurrentie die in de haast van de hervormingen niet goed was geregeld. Op Ambon stond de verkiezing van juni 1999 centraal. Christenen zouden hun slag slaan doordat zij sterk vertegenwoordigd waren in de partij PDI-P van Megawati. Een PDI-P-zege zou hun antwoord zijn op wat zij zagen als de oprukkende islam. Na slechts enkele maanden van haastige voorbereiding - onder druk van een ongeduldig publiek - kondigde de nationale regering in december 1998 aan dat de verkiezingen binnen zes maanden zouden plaatsvinden. Golkar, de seculiere partij van Soeharto waar de meeste leden van de Ambonese elite toe toebehoorden, werd algemeen gezien als een partij die op het punt van instorten te stond, hoewel dat later toch niet waar bleek te zijn. Vele kiezers stapten dan ook over naar alternatieve partijen met als gevolg dat de polarisatie toenam. De infrastructuur van politieke partijen was sterk verwaarloosd tijdens de autoritaire Nieuwe Orde, en regels bleven onduidelijk. Toch liepen de verwachtingen hoog op. De godsdienst was het best georganiseerd en daar zouden stemmen kunnen worden opgetrommeld.

\section{Geweld en lokale concurrentie}

Een soortgelijk verband tussen geweld en lokale concurrentie is te zien in alle communale episodes uit die periode. In Noord-Molukken ging het om het gouverneurschap van de nieuwe provincie, zojuist afgescheiden van de moederprovincie Maluku. In Poso, een provincie op Midden-Sulawesi, was de aanleiding de aanstelling van een nieuw districtshoofd en zijn secretaris; in Midden-Kalimantan de verkiezing van een nieuwe gouverneur en later een districtshoofd; en in West-Kalimantan de controle over een aantal nieuwe districten. Het is wereldwijd statistisch aangetoond dat de democratische overgang een gevaarlijk moment is voor de openbare vrede (Marshall en Gurr, 2003: 19-20). In Indonesië speelde het gevaar minder op nationaal niveau - de overgang verliep bijna overal goed - maar wel in een aantal blijkbaar zeer gevoelige regio's. Ondanks de geschiedenis van centralisme onder Soeharto, of misschien juist daardoor, kreeg de politiek na 1998 overal een sterk lokaal karakter.

'Alle politiek is lokale politiek', zei de Amerikaanse politicus Tip O'Neill eens. De lokale politiek drijft op velerlei organisaties die op hun beurt door informele netwerken worden onderbouwd. Parallelle studies bieden vaak inzicht. Berenschot (2009) beschrijft hoe sociale netwerken in Gujarat, India, een rol speelden bij het geweld in 2002. Daarbij draaide 
het om personen die tussen de staat en de gewone burger bemiddelden politici, partij-aparatchiken, informele ritselaars, ambtenaren, en kleine criminelen die de politiek van hun bazen kracht konden bij zetten. De staat biedt burgers steeds meer diensten aan, maar is zelf niet goed in staat die ook daadwerkelijk te leveren. Politieke makelaars verdelen die diensten wel, maar alleen in ruil voor loyaliteit. Door burgers aan zich te binden met zulke directe beloningen bouwen makelaars legertjes op om tegen concurrenten te kunnen optreden. Ideologie, vaak gebaseerd op communale identiteitsmythen, speelt een andere belangrijke rol. Geweld is dus instrumenteel inzetbaar als een tactiek in het voeren van een bewuste politiek, vooral als het een zwakke en arme staat betreft. Voor Ambon bestaat een dergelijke studie niet, maar wel kunnen wij iets soortgelijks opmaken uit algemenere gegevens over Indonesië.

De overeenkomst tussen Indonesië en stedelijke deelstaat Gujarat is bijvoorbeeld dat de staat in beide gevallen veel te bieden heeft aan patronage, maar dat de zwakke institutionele uitvoering dit doet weglekken via informele kanalen. Deze kanalen worden algemeen 'cliëntelistisch' genoemd. Een verschil tussen de politici in Gujarat en in Indonesië is dat in het laatste geval politici minder diep in de samenleving zijn geworteld dan die in Gujarat. Democratie is nieuw in Indonesië. Het verkiezingssysteem van evenredige vertegenwoordiging zorgt dat politici geen persoonlijke verantwoording afleggen in hun kiesdistrict. Politici stellen beleid en een begroting vast en hebben dus vooral iets te bieden aan zakenlieden. Voor kleine kwesties is de gewone burger op het relevante uitvoerende kantoor aangewezen. Steekpenningen en lobbyen komen bij veel van zulke instanties voor. Grotere overheidskantoren kennen een legertje aan informele makelaars (calo) die alles voor een prijs kunnen regelen. De belangrijkste verkiezingen in een gemiddelde Indonesische provinciestad zijn dan ook niet de parlementaire, maar de directe verkiezingen van districtshoofden en provinciale gouverneurs die in 2005 werden ingevoerd. Beide uitvoerende machten kregen onder de decentralisatieregeling van 2001 veel zeggenschap over het uitbesteden van projecten en de werkgelegenheid bij overheidsinstanties. Een kans op een overheidsbaan is een schaarser goed dan overheidsdiensten.

Kandidaten moeten hun eigen verkiezingsfondsen en campagnes verzorgen. Gezien de zwakke aanwezigheid in de provinciale samenleving van politieke partijmachines tussen de verkiezingen in, worden campagnes vaak toevertrouwd aan dorps-, familie- of geloofsgenoten die via hun netwerken geld inzamelen en kiezers op de been te brengen. Deze vertrouwelingen worden na een succesvolle verkiezing uiteraard beloond met banen en contracten. In een samenleving als Ambon, waar overheidsbanen door gebrek aan industriële ontwikkeling zeer begeerd zijn onder vooral goed opgeleide jongeren, leidde de introductie van 
democratische concurrentie in dit nepotistische systeem tot verhoogde spanning. Daar kwam bij dat de regels in 1998-1999 nog allerminst duidelijk waren. Parlementaire verkiezingen waren toen wel belangrijk, omdat bestuurshoofden nog indirect werden aangesteld door het lokale parlement. Kortom, in deze kansstructuur, alle reden voor mobilisatie. De rood gemaskerde jonge mannen in Gunung Nona speelden hoogstwaarschijnlijk een rol in een vage mobilisatiestrategie samengesteld door plaatselijke elites in een sfeer van gemengde hoop en paniek. Deze cliëntelistische netwerken bestaan al heel lang op Ambon en als de staat zelf verlamd is, worden zij ingeschakeld.

Gunung Nona ligt in de wijk Benteng in het westelijke gedeelte van de stad Ambon. De meeste werknemers in deze hoofdzakelijk door christenen bewoonde wijk hadden in 1999 een veilige baan als ambtenaar. Niettemin was de werkloosheid er aanzienlijk. Een hoofdzakelijk door moslims bewoonde wijk als Batumerah had echter maar weinig ambtenaren. De meesten werkten in de kleinhandel (Van Klinken, 2001). Vóór de burgeroorlog was Benteng voor 71,5 procent christen (52,7 procent protestant, de overigen katholiek). Van de werknemers was 71 procent ambtenaar. Maar in 1994 was 73 procent van de bevolking zonder werk. Dit cijfer telt weliswaar ook kinderen mee (33 procent onder de vijftien jaar!), maar dit betekent toch een hoge werkloosheid. In Batumerah (76 procent moslim) daarentegen was slechts acht procent van de werknemers ambtenaar, terwijl 78 procent zelfstandig handelaar of zakenman was. Cijfers over de werkloosheid in Batumerah zijn mij niet bekend.

Als iemand bij de overheid wil werken, dan helpt het dus als de persoon een christen is. De reden hiervoor kent een lange geschiedenis. Nederlanders gedurende de koloniale periode schreven er het eerste hoofdstuk van. Zij achtten christen-Ambonezen loyaler dan moslims en betaalden ze meer als soldaten. Christenen genoten daardoor een hoger onderwijsniveau. Na de onafhankelijkheid in 1945 wisten christen-Ambonezen hun superieure onderwijs te combineren met een taaie en loyale lobbytechniek in Jakarta om hun voorsprong in de lokale bureaucratie te behouden. Zelfs een grotendeels door christenen gevoerde opstand tegen de nieuwe Indonesische republiek in 1950 (de zogenaamde RMSopstand) kwamen ze weer te boven.

Naast objectieve factoren als onderwijsniveau speelde de nepotistische rekruteringspolitiek door de plaatselijke ambtenarij ook een belangrijke rol bij het in stand houden van bestaande groepsprivileges. Het nepotisme loopt door kerk en moskee heen, omdat de vertrouwensbanden tussen geloofsgenoten hechter zijn dan tussen niet-geloofsgenoten. Christenen zien elkaar vaak in de eredienst of kerkelijke nevenactiviteiten als gebeds- of jongerengroep. Op Ambon is de gemiddelde christen minstens één keer per week in de kerk, de meesten veel vaker. 
Elke jonge man of vrouw doet mee met een jongerengroep. Daarnaast zijn christenen vaker buren van elkaar. Zij woonden voor het conflict al vaak in een overwegend christelijke wijk, moslims in een moslimwijk en er bestaan maar weinig gemengde wijken. Het conflict heeft de segregatie verder doen toenemen.

Weinig geprivilegieerde burgers doen enthousiast mee aan kerk en moskee, omdat zij daar mogelijkheden vinden om vooruit te komen. Dit werd statistisch vastgesteld door een team van de Wereldbank op basis van survey-onderzoek in Indonesië (Grootaert, 1999). Dit rapport liet echter niet zien dat armen zich in een afhankelijkheidsrelatie moesten plaatsen om van die voorspoed via kerk of moskee te profiteren. Ondanks de grotere mogelijkheden voor christelijke jongeren bij de overheid in Ambon kenden zij ook veel werkloosheid. Dat leidde tot frustratie onder hen. Een grote groep goed opgeleide jongeren die voelden dat hun kansen door anderen worden belemmerd vormen overal een bekende bron van revolutionaire drang (Goldstone, 2001). Het is niet uit te sluiten dat de rood gemaskerde aanvallers op de moslimminderheid in Gunung Nona juist uit deze groep van gefrustreerde jongeren afkomstig was. Of zij ook uit de armere laag in Benteng kwamen is moeilijk te zeggen. Mogelijk stamden zij zelf uit families uit de middenklasse, dus kandidaten voor een baan.

Maar de latere christenmilities, gelegerd in posten langs de frontlinies die door het midden van de stad Ambon liepen, waren wel degelijk armere cliënten van de christelijke middenklasse. Veel van hen kwamen uit beruchte christelijke 'vechtersdorpen' op achtergebleven eilanden ten oosten van het grote eiland Ambon. Moslimmilitiemannen kwamen op een gelijke manier uit moslimdorpen buiten de stad. Alle inwoners van Ambon hebben emotionele banden met het dorp van hun voorouders. Als zij gegoed zijn, wordt van hen verwacht dat zij jonge familieleden uit die dorpen in huis nemen tijdens hun studie in de grote stad. Daarna helpen zij de afgestudeerde aan werk in ruil voor kleine wederdiensten zoals schoonmaken, feesten organiseren en - zo bleek in 1999 vechten. Kudamati, bijvoorbeeld, een protestantse wijk in hartje Ambon die lang op de frontlinie lag, stond al lang bekend voor zijn grote aantal semi-criminele, ongeschoolde sterke jongens afkomstig van het eiland Saparua.

Elders in Indonesië vond het ronselen van arme jongens eveneens tijdens de communale oorlogen van 1999 plaats. Toen communale spanningen in december 1998 opliepen in het stadje Poso, in Midden-Sulawesi, riepen christen- en moslimleiders al snel hulptroepen in. Vrachtwagens vol jonge mannen reden schreeuwend rond in het kleine stadje. De moslims waren afkomstig uit moslimdorpen langs de kustweg naar het westen en oosten en de christenen uit christendorpen in de bergen in 
het zuiden. Net als in Ambon wordt de arbeidsmarkt voor middenklassers in Poso beheerst door de bureaucratie. Buiten de stad is landbouw de belangrijkste bron van inkomsten, maar laten officiële statistieken zien dat voor stadsbewoners de overheid belangrijker is als bron van inkomsten dan de handel.

De stedelijke economie van alle provincies van Indonesië waar communaal geweld losbarstte rond 1999 waren bovengemiddeld afhankelijk van de overheid, gemeten door het aantal ambtenaren te delen door alle werknemers buiten de landbouw. Het zijn allemaal middelgrote provinciestadjes buiten het dichtbevolkte Java. Naast de ambtenarij, voor jongeren met een opleiding vaak hun enige kans van werk op passend niveau, biedt de overheid inkomsten uit bouwprojecten voor een groot aantal kleine aannemers. Toegang tot zulke werkgelegenheid in die plaatsen is hardnekkig cliëntelistisch. Duidelijk is dus dat de afhankelijkheidsrelatie tussen politieke makelaars en hun armere cliënten een rol speelde in het ontstaan van collectief geweld. Zulk geweld ontstaat immers alleen als veel gewone mensen meedoen. Betekent dit ook dat deze afhankelijkheidsrelaties de primaire reden was voor het ontstaan van grootschalig communaal geweld in Indonesië? Om de vraag goed te kunnen beantwoorden moeten we het begrip cliëntelisme zelf in beschouwing nemen, want dat begrip kent een lange geschiedenis waarbij de betekenis geleidelijk is veranderd.

\section{Cliëntelisme en klassensolidariteit}

Een patroon-cliëntverhouding wordt gedefinieerd als een ongelijke maar wederzijds heilzame verhouding tussen individuen of groepen, op basis van 'neem daar, geef hier' (Roniger, 2004). De patroon heeft een bevoorrechte toegang tot begeerde middelen, zoals overheidssubsidies, banen, bescherming, of vergunningen, of zelfs tot marktgoederen als kennis en krediet. Hij (zelden zij) stelt deze alleen ter beschikking aan cliënten die hem directe politieke, sociale of economische steun verlenen. De waarde van de verhouding is dus gebaseerd op het voordeel voor de patroon. Politiek die op cliëntelisme berust is particularistisch, maar niet universeel. Burgers hebben geen vrije toegang tot de staat, evenmin als handelaren tot de vrije markt. De cliëntelistische verhoudingen zijn overal teruggevonden, ook in Indonesië (Eisenstadt, 1973; Roth, 1968). Niet alleen collectief geweld, maar ook corruptie en problemen in de democratie worden vooral in Afrika en in Zuid- en Zuidoost-Azië vaak verklaard met verwijzing naar het begrip cliëntelisme.

Rond de jaren zestig werden cliënten als geheel passief gezien en als verbonden aan hun meerderen door een diepgewortelde traditionele eerbied. Zo verklaarde Jackson (1980) de bloedige Darul Islam-opstand 
in West-Java in de jaren vijftig, toen arme boeren elkaar aanvielen vanwege de godsdienst, door te stellen dat cliëntelistische loyaliteit van de boeren aan hun politieke elites sterker was dan hun onderlinge klassensolidariteit. De aliran, de godsdienstige gezindheid die de Javaanse samenleving verdeelde in verticale kolommen van onderdanigheid op een manier die vaak wordt vergeleken met de Nederlandse verzuiling op zijn hoogtepunt, werd door Geertz (1960) beschouwd als het permanente basisprincipe van Java. Jay (1971) legde de anticommunistische pogroms in Oost-Java van 1965-1966 uit langs dezelfde lijnen. Gedurende die eerste wereldwijde golf van studies over cliëntelisme, waarin wetenschappers die zich met Indonesië bezighielden een aanzienlijke rol speelden, hoopten sommigen wel dat arme Indonesische boeren uiteindelijk hun afhankelijkheid aan elites zouden afwerpen ten gunste van een klassenorganisatie (Scott, 1972; Wertheim, 1969). Hun werk vond echter weinig weerklank.

In de decennia daarna verschenen steeds meer studies over het fenomeen die duidelijk maakten dat het cliëntelisme niet snel zal verdwijnen onder druk van modernisering, niet beperkt is tot ontwikkelingslanden, en ook niet geheel negatief is (Eisenstadt en Roniger, 1984; Roniger, 2004). Naarmate de belangstelling voor civil society en democratisering op lokaal niveau groeide, zagen wetenschappers in dat ongelijke vriendschappen, bijzondere netwerken van vertrouwen en geloof, wederzijdse uitwisselingen van middelen in ruil voor loyaliteit, een normaal deel van het leven zijn, vooral voor kansarme burgers. Vertrouwensnetwerken kunnen gebaseerd zijn op geslacht, familiebanden, op banden tussen dorpelingen, vermeende etnische afkomst of godsdienst. Universele begrippen als staat, samenleving, de autonome burger, en democratie hebben weinig betekenis te midden van deze concrete verhoudingen. De hernieuwde aandacht voor lokale politiek in Indonesië leidt momenteel tot een herontdekking van het fenomeen cliëntelisme (Schulte Nordholt en Van Klinken, 2007). De cliëntelistisch netwerken die kerkleden met hogere plaatselijke ambtenaren verbinden en die gemobiliseerd werden in 1999, zijn hier duidelijk een voorbeeld van. Ze hebben hun wortels in de geschiedenis van staatsformatie, vooral via het systeem van indirect bestuur gebruikelijk in Nederlands-Indië.

De essentie van cliëntelisme is particularisme. Factionalisme en eigenbelang overheersen het beeld. Grotere groeperingen lijken niet te bestaan. Christen- en moslimelites leken op Ambon zo gepolariseerd dat zij niets gemeen hadden. De ongelijke verhoudingen binnen etnische organisaties waar rijk en arm aan toebehoren, geven etnische politiek een donker, conservatief karakter. Christenen in Ambon staan sociaal ongeveer op dezelfde trap als moslims, ondanks beroepsverschillen. Dat is anders dan bijvoorbeeld zwarten in de VS, die overwegend arm zijn. 
Horowitz (1985: 21-36) noemde het eerste Indonesische type een systeem zonder rangorde en het tweede een gerangschikt systeem. Etnische politiek in een gerangschikt systeem heeft het karakter van een klassenstrijd door armen tegen het onrecht. In een systeem zonder rangorde heeft de etnische politiek daarentegen een conservatief karakter, gemanipuleerd door elites die hun eigen belangen behartigen.

Het donkere karakter is gemakkelijk te herkennen in het Indonesische communale geweld rondom 1999. Soortgelijke waarnemingen uit India en Afrika beneden de Sahara laten hetzelfde zien. Gurr (1993) laat zien dat zulke militante etnische groepen, zonder het huidige gezag omver te willen werpen, streven naar behoud of mogelijk verbetering, van de eigen positie. Christenen op Ambon zagen in 1999 de gelegenheid om hun voormalige dominantie in de lokale bureaucratie, teruggedreven door geleidelijke emancipatie van de moslims, te herstellen. Gezien de onzekerheden bij iedere nieuwe verkiezingsprocedures schrokken hun christelijke elites niet terug voor intimidatie, die vervolgens geheel ontaardde. Zo moeten wij waarschijnlijk die rood gemaskerde jongens zien in Gunung Nona. Niet-christelijke stemgerechtigden moesten weg uit Ambon, en werden niet toegelaten tot na de verkiezing. Een soortgelijke strategie van plaatselijke etnische zuivering voor politieke doeleinden zag men ook elders in Indonesië, en is maar al te bekend in andere landen, zoals in 2008 in Kenia.

Toch vertoont het cliëntelisme in recente studies andere trekken dan dat in de jaren zestig. Cliëntelistische verhoudingen worden al lang niet meer beschouwd als piramiden van passieve boeren waar elites alles over te zeggen hebben. 'Neo'-patrimonialisme omvat cliëntelistische verhoudingen die niet langer in stand worden gehouden door traditionele eerbied voor meerderen, maar door zeer praktische middelen als geld. In een stedelijk milieu betekent cliëntelisme geen levenslange band meer. Het is een meestal tijdelijke, niet onvoorwaardelijke, en dus bijna zakelijke verhouding. Zelfs een gezamenlijke ideologie is geen vereiste meer in de laatste beschrijvingen van het cliëntelisme. Landé (1965) zag dit al in zijn baanbrekende proefschrift over de Filippijnen in de jaren zestig, maar het werd pas veel later geaccepteerd door de meerderheid van onderzoekers over dit onderwerp (zie Kitschelt en Wilkinson, 2007; Piattoni, 2001).

Als de geleidelijke verschuiving in het begrip cliëntelisme nog enige tijd doorgaat, komt de bruikbaarheid in de toekomst op losse schroeven te staan. Het is bijvoorbeeld niet duidelijk hoeveel van de vechters in het Indonesische communale geweld rondom 1999 wel echt afhankelijke cliënten waren, in de zin van mensen die niet voor hun eigen directe belangen vochten, maar voor die van hun maatschappelijke meerderen. Sommige plattelandsjongens waren misschien gewoon huurlingen, die 
weinig van hun autonomie prijs hoefden te geven aan hun bazen uit de middenklasse. In de anti-Madurese pogroms van Midden- en West-Kalimantan zijn er indicaties dat bepaalde acties geen uitbarstingen waren van woedende armere mensen, maar koelbloedig geplande aanvallen met inzet van gehuurde krachten. In Midden-Kalimantan waren dit misschien werknemers in de houtkap uit het binnenland. In latere episodes van geweld in West-Kalimantan waren het waarschijnlijk semi-criminele, halfwerkloze, harde jongens zonder scholing, preman genoemd, die in alle grotere steden rondom markten of busstations voor het uitoefenen van zulke gewelddadigheden beschikbaar zijn. Huurlingen hebben een dergelijk pragmatische verhouding met hun opdrachtgever, zodat 'contract' wellicht een toepasselijker begrip is dan cliëntelisme.

De onveiligheid van een geweldssituatie plaatst gewone deelnemers voor hoogst abnormale keuzes. Die offeren op een dergelijk ogenblik graag persoonlijke autonomie in ruil voor garanties van veiligheid. Ze worden cliënt voor een momentje, plaatsen zich onder beschermheren voor wie ze normaal gesproken weinig respect hebben. Mobiliserende elites spreken wel bestaande banden aan. Cliëntelisme is een bijzonder effectieve techniek om mobilisatie onder omstandigheden van verminderde veiligheid op gang te brengen. Maar buiten zulke extreme situaties is cliëntelisme minder effectief. Democratisering doet de machtsbalans in een cliëntelistische verhouding langzaam omslaan in de richting van de cliënt. Naarmate democratie normaal wordt in Indonesië, neemt het protest toe tegen de corruptie die ten grondslag ligt aan bijzondere cliëntelistische netwerken. Zulk protest wordt ook luidruchtiger in landen als India of Japan. Cliëntelisme moet allerminst gezien worden als een onwrikbaar gegeven. De toename van praktische, tijdelijke en strategische overwegingen door de cliënt leidt tot een verzwakking van de afhankelijkheidsrelatie.

Dit stelt de oude vraag van Scott en Wertheim opnieuw aan de orde, namelijk of de verhouding tussen patroon en cliënt uiteindelijk wel zo belangrijk zal blijken te zijn als vroeger werd gedacht. Speelt het niet eerder een ondergeschikte rol in een dynamiek die door andere krachten wordt gedreven? De dynamiek van cliëntelisme en klassenconflict doen zich vaak tegelijkertijd voor. Ze staan deels haaks op elkaar, maar lopen deels ook parallel. Cliëntelisme versterkt banden tussen hogere en lagere maatschappelijke groepen, en verzwakt banden tussen rivaliserende elites. Maar het dient hoofdzakelijk de belangen van de elites. Zij gebruiken cliëntelisme als techniek om hun macht te bevestigen. Cliëntelisme is klassenonderdrukking zonder klassenstrijd. Via allerlei particularistische deals proberen zij meer individuen en groepjes in hun greep te houden, zonder veel van hun eigen autonomie prijs te hoeven geven. Naarmate volgelingen minder volgzaam worden, gebruiken eli- 
tes voor hetzelfde doel ook andere technieken. Eén daarvan is geweld tegen diezelfde volgelingen. In Ambon werd dat vooral gebruikt onder moslimgroepen. De solidariteit onder moslimorganisaties was zwakker dan binnen de kerk. Geweld tegen volgelingen druist in tegen de, in principe vrijwillige en wederzijds heilzame, cliëntelistische verhouding. Een ander middel is legitieme institutionele macht, bijvoorbeeld de wet. Die is uiterst zwak in Indonesië. Toch zijn er militieleiders wettelijk veroordeeld voor hun buitensporig gedrag, vooral aan beide kanten van het gruwelijke conflict tussen christenen en moslims in Poso.

Klassenbelangen stellen grenzen aan het typisch cliëntelistische factionalisme. Achter de factionele oorlogen schuilen grote factieoverschrijdende belangen. De meeste provinciale elites in Indonesië hebben gemeenschappelijk belang bij een maximale overheidsbegroting, maximale discretie in de uitbesteding, en efficiënte afwering tegen bedreigingen van deze belangen. Zelfs in de extreem diep verdeelde samenleving van Ambon rond 1999 waren deze gezamenlijke belangen te zien. Enthousiasme voor de decentralisatie was er net zo groot als in alle provinciesteden buiten Java. Zo ook de vrees dat de volksprotesten tegen Soeharto wel eens een communistische wending konden nemen als arbeiders of land reform-bewegingen het initiatief zouden nemen, en de overtuiging dat de godsdienst hier een goed tegengif voor was. Door alle burgeroorlogen heen werden vredige verkiezingen gehouden. Niemand was dan ook bereid om factionele verschillen zo hoog te laten oplopen dat het systeem zelf, waar iedereen zoveel baat bij had, op het spel zou komen te staan. Het leed van de vele gewone slachtoffers is sindsdien dan ook in alle talen verzwegen - er is nooit een waarheidscommissie op Ambon gekomen.

De geschiedenis van politieke actie door provinciale actoren sinds de onafhankelijkheid van 1945 illustreert deze belangen. Het basisidee werd op briljante wijze aangegeven in een kort artikel van de econoom Kalecki (1972). Hij betoogde dat intermediate classes onder bijvoorbeeld Nasser in Egypte en Soekarno in Indonesië de staat hadden 'overgenomen'. Ze konden dit doen niet omdat ze rijk waren, maar omdat ze zoveel herrie konden schoppen. Rijkere concurrenten - vooral Nederlanders, Chinezen, en Javaanse aristocraten - werden terzijde geschoven door middel van politieke ideologieën (respectievelijk nationalisme, racisme en socialisme). Georganiseerde armen werden in toom gehouden door cliëntelistische banden en uiteindelijk uitgeschakeld door de militaire terreur van 1965/1966 (Van Klinken, te verschijnen).

Robison was de eerste die een oproep deed voor onderzoek naar wat hij noemde de populist lower middle classes en de indigenous petty bourgeoisie in Indonesië. De eerste beschreef hij als 'a much-neglected and underrated research category of the middle class... [a] sprawling mass of clerks, 
teachers and lower-level civil servants which often intersects with the petty bourgeoisie and, in the countryside, with the smaller landowning families. This army of minor officials and private sector clerks has proliferated with the development of modern capitalist society' (1996: 88-90). Over de laatsten, namelijk de klein- en middelgrote ondernemers, zei hij dat zij een 'strenge mentaliteit' hadden gericht tegen de Chinese handelaren.

Een boek over het verwrongen marktmechanisme in kleinstedelijk India van de econoom Harriss-White (2003) beschrijft de verhoudingen tussen een middenklasse en hun armere volksgenoten zonder het begrip cliëntelisme centraal te plaatsen. Zij schildert deze niet in termen van solidariteit doordrenkt met vertrouwen, of als een zinvolle gemeenschap, maar als venijnige afpersing en diefstal, ondersteund door harde politiek. Exclusieve groepspolitiek was een manier om de prijs van schaarse goederen op te drijven ten gunste van de leidende elites. Harriss-White inspireerde de econoom Mushtaq Khan om het begrip 'middenklasse' toe te passen in zijn studie over rente en rent-seeking in Azië. Hij bedoelde hiermee niet zozeer een inkomstencategorie als wel een losse strategische coalitie die gekenmerkt wordt door politieke actie. Hij beschreef deze (Khan, 2000: 35-40) als 'urban petty-bourgeoisie, the rich peasantry and other emerging middle classes'. Deze leden uit de lagere middenklasse verwerven hun invloed vooral in de provincie niet door hun rijkdom - ze zijn niet rijk -, maar doordat zij uitstekend kunnen organiseren. Anders dan de traditionele middenklassen, die bang zijn voor de sans-culottes en die trouwens minder omvangrijk zijn dan de intermediate classes, winnen zij aan invloed door te mobiliseren. Zij zetten daarbij cliëntelisme in als techniek en verhogen hun aantrekkingskracht door toegang tot de begeerde staats- en marktgoederen opzettelijk te beperken. De onveroorloofde winst die zij daaruit halen, boven het normale dat te verwachten valt in een open markt, wordt rente genoemd. De corruptie, de lage kwaliteit van de democratie die zij bevorderen en de soms gewelddadige mobilisatie van etnische cliënten gaan dus samen. Ze vinden alle hun bron, niet in het cliëntelisme zelf, maar in de materiële belangen van de nieuwe middenklassen.

\section{Na het geweld}

Terugkijkend op het geweld van Ambon is er veel geleerd. Zo zijn de regels voor een verkiezing duidelijker geworden. Wervingsprocedures voor nieuwe ambtenaren zijn misschien nu iets transparanter. Milities zijn ontbonden en de politie treedt op met grotere vastberadenheid dan in 1999. Leden van elites die veel bloed aan hun handen hebben, hoewel zelden veroordeeld, zijn ze politiek gemarginaliseerd. De dominante 
groepen op Ambon en elders hebben hun factionalisme voorlopig bijgelegd. Dit alles versmalt de mogelijkheden voor gewelddadige provinciale politiek. Maar structurele verandering lijkt in de maatschappij nog ver te zoeken. Ook na het vredesverdrag van begin 2002 blijven godsdienstige politieke partijen populairder dan elders in Indonesië. Samen met andere plaatsen waar communaal geweld het ergst was, is de economie van Ambon nog steeds bovengemiddeld afhankelijk van staatswerkgelegenheid. Tot dusver zijn er weinig tekenen dat armen zich onafhankelijk beginnen te organiseren rond hun eigen materiële belangen.

Maar niets staat stil. De weberiaanse socioloog Theobold (1982: 557558) schreef over het patrimonialisme - waaraan cliëntelisme is gerelateerd - dat het begrip het gevaar liep zijn betekenis te verliezen als het niet duidelijk geplaatst werd in een geschiedenis van economische ontwikkeling. Naarmate de economie van Indonesische provinciestadjes als Ambon minder afhankelijk wordt van de staat en de wereldmarkt ook daar begint door te dringen, en de idealen van de democratie ook buiten de middenklassen verlangens beginnen te ontlokken, zullen de armen zich waarschijnlijk onafhankelijker gaan organiseren.

\section{Literatuur}

Berenschot, W. (2009). Riot politics: communal violence and state-society mediation in Gujarat, India. Proefschrift Universiteit van Amsterdam.

Eisenstadt, S.N. (1973). Traditional patrimonialism and modern neo-patrimonialism. Beverly Hills: Sage Publications.

Eisenstadt, S.N. en L. Roniger (1984). Patrons, clients and friends: interpersonal relations and the structure of trust in society. Cambridge: Cambridge University Press.

Geertz, C. (1960). The religion of Java. New York: Free Press of Glencoe.

Goldstone, J.A. (2001). Demography, environment, and security. In P.F. Diehl en N.P. Gleditsch, Environmental conflict. Boulder: Westview Press.

Grootaert, C. (1999). Social capital, household welfare and poverty in Indonesia. Local Level Institutions Study, Social Development Department, Environmentally and Socially Sustainable Development Network, The World Bank.

Gurr, T.R. (1993). Minorities at risk: A global view of ethnopolitical conflicts. Washington DC: US Institute of Peace Press.

Harriss-White, B. (2003). India working: essays on society and economy. Cambridge: Cambridge University Press.

Horowitz, D.L. (1985). Ethnic groups in conflict. Berkeley: University of California Press.

Human Rights Watch (1999). The violence in Ambon. Washington: Human Rights Watch Asia. 
Jackson, K.D. (1980). Traditional authority, Islam and rebellion: a study of Indonesian political behavior. Berkeley and Los Angeles: University of California Press.

Jay, R.R. (1971). History and personal experience: religious and political conflict in Java. In R.F. Spencer, Religion and Change in Contemporary Asia. Minneapolis: University of Minnesota Press.

Kalecki, M. (1972). Social and economic aspects of 'intermediate' regimes. In M. Kalecki, Selected essays on the economic growth of the socialist and the mixed economy. New York: Cambridge University Press.

Khan, M.H. (200o). Rents, efficiency and growth. In M.H. Khan en K.S. Jomo, Rents, rent-seeking and economic development: Theory and evidence in Asia. Cambridge: Cambridge University Press.

Kitschelt, H. en S.I. Wilkinson (2007). Patrons, clients and policies. Cambridge: Cambridge University Press.

Klinken, G. van (2001). The Maluku wars: Bringing society back in. Indonesia, 71, 1-26.

Klinken, G. van (2007). Communal violence and democratization in Indonesia: small town wars. London: Routledge.

Klinken, G. van (in press). Decolonization and the making of Middle Indonesi. Urban Geography.

Landé, C.H. (1965). Leaders, factions and parties: the structure of Philippine politics. New Haven: Yale University.

Marshall, M.G. en T.R. Gurr (2003). Peace and conflict 2003: a global survey of armed conflicts, self-determination movements, and democracy. College Park, MD, USA: Center for International Development and Conflict Management (CIDCM), University of Maryland.

McAdam, D., S. Tarrow en C. Tilly (2001). Dynamics of contention. Cambridge: Cambridge University Press.

Piattoni, S. (2001). Clientelism, interests, and democratic representation: the European experience in historical and comparative perspective. Cambridge: Cambridge University Press.

Robison, R. (1996). The middle class and the bourgeoisie in Indonesia. In R. Robison, The new rich in Asia: mobile phones. McDonald's and middleclass revolution. London: Routledge.

Roniger, L. (2004). Review article: political clientelism, democracy, and market economy. Comparative Politics, 36, 353-375.

Roth, G. (1968). Personal rulership, patrimonialism and empire building in the New States, World Politics, 20, 194-206.

Schulte Nordholt, H. en G. van Klinken (2007). Renegotiating boundaries: local politics in post-Suharto Indonesia. Leiden: KITLV.

Scott, J.C. (1972). The erosion of patron-client bonds and social change in rural Southeast Asia. Journal of Asian Studies, 32, 5-37.

Tanter, R. (2002). Witness denied: Australian media responses to the Indonesian killings of 1965-66. Inside Indonesia, 71. 
Theobold, R. (1982). Patrimonialism. Research note. World Politics, 34, 548559.

Tilly, C. (1978). From Mobilization to Revolution. Reading, Mass.: Addison150 Wesley.

Wertheim, W.F. (1969). From aliran towards class struggle in the countryside of Java. Asia Pacific Viewpoint, 10, 1-17. 


\title{
Een theoretisch perspectief op etnisch geweld
}

\author{
Ton Zwaan
}

\section{Politiek geweld en etnisch geweld}

Politiek geweld heeft volgens een recente schatting in de twintigste eeuw wereldwijd omstreeks 187 miljoen mensen het leven gekost. Dat aantal komt overeen met ongeveer tien procent van de wereldbevolking in 1914 en ongeveer drie procent van de huidige wereldbevolking. Circa zestig miljoen van hen zijn omgekomen in de beide wereldoorlogen, ruwweg tien miljoen in de eerste en ongeveer vijftig miljoen in de tweede. Waarschijnlijk zijn in de loop van de eeuw tussen de veertig en zestig miljoen mensen om het leven gebracht door tegen hen gerichte vervolging, massamoord en genocide. De overigen, mogelijk nogmaals ongeveer zestig tot tachtig miljoen mensen, zijn omgekomen als gevolg van de ruim 220 andere oorlogen en burgeroorlogen die in de afgelopen eeuw hebben plaatsgevonden (Hobsbawm, 1994: 12; De Swaan, 2003: 15; Zwaan, 2005: 9). Niemand kan zich een adequate voorstelling maken van dergelijke kolossale aantallen slachtoffers en daarmee van de frequentie, de schaal en de intensiteit van het gepleegde geweld - de menselijke geest biedt daar te weinig mogelijkheden toe. Maar dat laat de kern onverlet: het is allemaal echt gebeurd. En het maakt onomstotelijk duidelijk dat massaal politiek geweld behoort tot de meest fundamentele problemen van menselijke samenlevingen en van de mensheid als geheel.

Wat kunnen we verstaan onder politiek geweld? 'Politiek' kan in het voetspoor van Max Weber (Weber, 1988 [1921]) ruim worden omschreven als elk streven naar een machtsaandeel of naar beïnvloeding van de machtsverdeling tussen staten of binnen een staatsverband tussen de mensengroepen die er deel van uitmaken. Wie politiek actief is, streeft macht na. Meestal als middel om bepaalde doelen te realiseren, maar doorgaans ook om te genieten van het prestigegevoel dat macht kan verschaffen. Macht is ook een bron van menselijk genot. Vanuit deze visie 
kan politiek geweld worden beschouwd als al dat geweld dat primair gericht is op het behouden of verwerven van politieke macht, of op beïnvloeding van bestaande machtsverdelingen tussen en binnen staten. Daarmee kan politiek geweld in principe ook onderscheiden worden van bijvoorbeeld crimineel geweld en andere vormen van privégebruik van geweld. Overigens kunnen politiek geweld en crimineel geweld soms nauw met elkaar verweven zijn, zoals ook duidelijk blijkt uit de gevalstudies in dit boek. In elk afzonderlijke regio is het daarom raadzaam de aard en context van geweld eerst nader te onderzoeken en niet prematuur af te gaan op formele theoretische classificaties van typen van geweld.

Dat geldt ook voor de term 'etnisch geweld'. Zoals aangestipt in de inleiding is etnisch geweld in feite een specifieke vorm van politiek geweld en kan het ook het beste als zodanig geanalyseerd worden. $\mathrm{Nu}$ hebben oorlog, burgeroorlog en genocide - de meest destructieve vormen van massaal politiek geweld - vrijwel altijd ook in meerdere of mindere mate etnische dimensies, maar bij etnisch geweld gaat het erom dat etnische spanningen en conflicten, tegenstellingen en scheidslijnen dominant zijn. De betrokken partijen - daders en slachtoffers in allerlei denkbare configuraties - definiëren zichzelf en elkaar primair in etnische termen, het geweld wordt gemotiveerd en gelegitimeerd door overwegend etnische argumenten. De mobilisering van geweld vindt dan plaats op basis van verondersteld lidmaatschap van etnische groepen en het daadwerkelijke geweld vindt hoofdzakelijk plaats langs etnische scheidslijnen. Wie tot de andere etnische groep behoort, wordt louter en alleen op grond daarvan beschouwd als een potentieel bedreigende vijand dan wel als een doelwit voor destructie, en meestal beide tegelijk. Wanneer van dit alles sprake is, kan het voorkomende politieke geweld zinvol benoemd worden als etnisch geweld.

Het ziet ernaar uit dat dit type politiek geweld in de recente geschiedenis steeds meer op de voorgrond is getreden. Zich baserend op een zeer omvangrijke dataset, waarin gewelddadige conflicten met meer dan duizend doden over de afgelopen twee eeuwen zijn opgenomen, hebben drie onderzoekers onlangs betoogd dat 'etno-nationalistische conflicten' in de eeuw tussen het Congres van Wenen in 1814 en de Vrede van Versailles in 1919 slechts 20 procent van alle oorlogen uitmaakte. Tussen 1919 en 2001 zou dat percentage gestegen zijn naar 45 procent en sinds het einde van de Koude Oorlog zou het zelfs 75 procent van alle gevallen betreffen (Wimmer, Cederman en Min, 2009). Zonder in te gaan op de complicaties van dit type onderzoek, lijkt de gesignaleerde trend aannemelijk. En het dagelijkse nieuws bevestigt die indruk: van voormalig Joegoslavië en de Kaukasus tot Irak en Afghanistan, van Sri Lanka tot Kasjmir, van Tibet en Xinjiang in China tot Israël en Palestina, van Zim- 
babwe en Kenia tot Rwanda, Congo en Somalië, in al die brandhaarden van de laatste tijd speelt etnisch geweld, veelal verbonden met andere vormen van politiek geweld, een hoofdrol.

De vraag is hoe dat komt. Hoe en waarom ontstaat keer op keer massaal etnisch geweld in uiteenlopende samenlevingen op allerlei verschillende plaatsen in de wereld? Onder welke politieke, economische en sociaal-culturele condities kunnen mensen, individueel en in collectief verband, betrokken raken bij de ontwikkeling van etnisch geweld? Wat is de rol van het wereldstatenstelsel en van regionale statenstelsels hierin? Welke staten in welk stadium van staatsvorming zijn meer kwetsbaar voor etnisch geweld en welke minder? Wat is de invloed van processen van natievorming? En waarom is etnisch geweld in de hedendaagse wereld zo prominent geworden? Om die vragen te kunnen beantwoorden zijn kennis en inzicht nodig over langetermijnprocessen van staatsvorming en natievorming en van economische en culturele ontwikkeling, maar ook van dergelijke ontwikkelingen op middellange termijn en van een veelheid van situationele omstandigheden en gebeurtenissen op korte termijn.

In de vijf gevalstudies in dit boek, over Turkije, Rwanda, Congo, India en Indonesië, laten de auteurs op voorbeeldige wijze zien hoe ingewikkeld het begrijpen en verklaren van etnisch geweld is. Juist door te beschrijven en te interpreteren wat er op lokaal of regionaal niveau precies gebeurt, wordt duidelijk hoeveel verschillende actoren met een variërende speelruimte en met uiteenlopende belangen en motieven betrokken zijn bij het ontstaan en de ontwikkeling van etnisch geweld. Ook wordt getoond hoe geweld, als het eenmaal op gang gekomen is, neigt naar een eigen, relatief autonome dynamiek. Massaal geweld is besmettelijk: eenmaal ergens ingezet is de kans groot dat het tegengeweld oproept dat vervolgens weer gewelddadig gewroken moet worden, en zo kan een hele regio of samenleving naar toenemende anarchie en anomie gaan tenderen. Dan geldt nog slechts het recht van de sterkste en als een dergelijke ontwikkeling ver is voortgeschreden, zoals in het oosten van Congo of in het hedendaagse Darfur of Somalië, dan is het is altijd buitengewoon moeilijk die situatie te stoppen en te keren. Zo'n situatie wordt onder meer gekenmerkt door een hoge mate van fragmentatie van het geweldsmonopolie, meerdere partijen betwisten elkaar gewapenderhand de oppermacht. Onveiligheid, onzekerheid en onberekenbaarheid domineren. Wet en recht, justitie en politie ontbreken. Door de strijd is omvangrijke materiële en infrastructurele schade aangericht. Er zijn grote aantallen doden en gewonden gevallen en vluchtelingenstromen ontstaan. Aanzienlijke verarming, voedselschaarste en vele onbehandelde ziekten zijn meestal het gevolg. Een structurele wending kan slechts optreden door hernieuwde pacificering, als de strijdende partijen hun 
geweld staken of als de internationale gemeenschap met overmacht intervenieert. Maar het kan lang duren voordat betrokken partijen oorlogsmoe zijn en de internationale gemeenschap is veelal noch bereid noch in staat effectief in te grijpen. Zolang zo'n herpacificering uitblijft, houden anarchie en anomie de overhand.

Het daadwerkelijke etnische geweld wordt uiteindelijk gepleegd door specifieke mensen en groepen tegen anderen op lokaal niveau, maar het kan niet uitsluitend in lokale of regionale termen worden begrepen. Collectieve etnisch-nationale identificaties overstijgen het lokale niveau, plaatselijke verhoudingen van macht en afhankelijkheid in politiek en economisch opzicht zijn altijd deel van wijdere en meeromvattende maatschappelijke netwerken en worden daar mede door bepaald. Het functioneren van de staat - in principe de houder en hoeder van het geweldsmonopolie - blijkt van fundamentele betekenis. Micro- en macroverbanden zijn door vele onzichtbare draden met elkaar verweven, centrum en periferie staan altijd in wisselwerking met elkaar. In verscheidene hoofdstukken komt scherp naar voren dat de wijze waarop de staatsorganisatie en de overige samenleving met elkaar vervlochten zijn, de differentiële toegang tot de staat en de concurrentie over die toegang tussen verschillende groepen, een cruciale rol spelen in het ontstaan en de ontwikkeling van etnisch geweld. Wie beschikt over een lucratieve toegang tot de staat en zijn hulpbronnen zal deze doorgaans willen behouden of uitbreiden en onder bepaalde condities ook bereid zijn anderen, desnoods met geweld, daarvan uit te sluiten. En wie systematisch buitengesloten wordt, zal daar soms met geweld tegen in verzet komen.

De auteurs in deze bundel belichten diverse aspecten en dimensies van etnisch geweld en leggen in hun interpretaties en verklaringen verschillende theoretische accenten, maar in hun werkwijze zijn drie belangrijke overeenkomsten aan te wijzen. Allereerst worden de beschreven gewelddadige gebeurtenissen zo goed mogelijk in een bepaalde maatschappelijke context geplaatst, gecontextualiseerd. Door te laten zien wie op onderscheiden maatschappelijke en relevante niveaus de belangrijkste actoren zijn, wat hun voornaamste drijfveren, belangen en motieven zijn, en hoe hun onderlinge spanningen onder bepaalde voorwaarden oplopen om uiteindelijk uit te monden in etnisch geweld, wordt het geweld zelf minder onbegrijpelijk. Geweld is onder andere een extreme en ook riskante vorm van machtsuitoefening en wie wint in een gewelddadige concurrentiestrijd behoudt of verwerft macht en maatschappelijke sterkte.

Ten tweede worden in alle hoofdstukken de gewelddadige episodes ook in meerdere of mindere mate gehistoriseerd - ook al domineert hier en daar het kortetermijnperspectief van de handelende personen en 
groepen. Door te verwijzen naar meeromvattende langetermijnontwikkelingen van en in de betrokken staatssamenlevingen, door aandacht te besteden aan de groepsrelaties voordat het etnische geweld zich voordeed of te refereren aan eerdere perioden van soortgelijke gewelddadigheden, wordt de dynamiek van de voortdurende maatschappelijke ontwikkeling duidelijker. Etnische diversiteit binnen een natie is nooit spanningsloos, maar etnische groepen kunnen heel wel min of meer vreedzaam samenleven binnen een staatsverband. Etnisch geweld vloeit niet simpelweg voort uit etnische diversiteit en is noch vanzelfsprekend noch inherent onvermijdelijk. Ook dat komt duidelijk uit de diverse bijdragen naar voren.

Ten slotte hanteren alle auteurs een vergelijkend perspectief: in alle hoofdstukken worden meer of minder expliciet diachrone en synchrone vergelijkingen gemaakt, waardoor de beschrijvingen aan scherpte winnen en de geboden verklaringen aan plausibiliteit. Uit deze bundel blijkt dat deze drie onderzoeksstrategieën van contextualisering, historisering en vergelijking goede kansen bieden op vergroting van kennis en verbetering van inzicht in het onderzoek naar politiek geweld.

In hoeverre dat gelukt is in de afzonderlijke bijdragen en in dit boek als geheel kan de lezer uiteraard zelf bepalen. Hier wordt kort ingegaan op een aantal algemenere kwesties die deels al in de inleiding zijn genoemd.

\section{Naar een geïntegreerd perspectief}

Zoals in de inleiding uiteengezet, zijn primordialisme, instrumentalisme, sociaal-constructivisme en het (cultureel-)psychologische perspectief de meest voorkomende benaderingen als het gaat om de verklaring van etnisch geweld. Elke benadering heeft enkele kenmerkende algemene uitgangspunten en veronderstellingen, vestigt de aandacht op bepaalde facetten van etnisch geweld en pretendeert een zekere opheldering en verklaring te bieden. In veel studies uit de laatste decennia klinken deze visies door, en zowel binnen academische vakkringen als daarbuiten is en wordt erover gedebatteerd.

Inmiddels lijkt de tijd rijp om te streven naar een geïntegreerd theoretisch perspectief. Wie daar een begin mee wil maken doet er goed aan enige afstand te nemen van de genoemde visies, geen keuze te maken voor een van de vier en geen partij te kiezen in de soms verhitte discussies tussen aanhangers van deze perspectieven. Een volgende stap kan dan zijn de sterkten en zwakten van de verschillende benaderingen na te gaan. Tot slot kunnen dan wellicht de sterke kanten van de verschillende visies samengebracht worden in een geïntegreerd perspectief. Idealiter zou zo'n perspectief de mogelijkheid moeten bieden om bij de beschrij- 
ving en analyse van specifieke gevallen van etnisch geweld de meest plausibele theoretische inzichten uit de verschillende visies welbewust met elkaar te combineren en die dan weer in verband te brengen met kennis en inzicht omtrent relevante ontwikkelingen van staat en natie, economie en cultuur, op middellange en lange termijn. Het primordialisme, momenteel uit de mode en verguisd in academische kring, maar gangbaar en populair in het algemene publieke debat, stelt in zijn meest eenvoudige vorm dat het louter bestaan van aanzienlijke etnische diversiteit binnen een staatssamenleving, van primordiale ('oorspronkelijke') etnisch-culturele verschillen tussen bevolkingsgroepen en derhalve van etnische scheidslijnen, de voornaamste reden is voor het ontstaan van etnisch geweld. Soms wordt daarbij geaccentueerd hoe wezenlijk, diepgeworteld, duurzaam en onveranderlijk etnische verschillen in voorkomende gevallen zijn; dat deze in het verleden ook al tot gewelddadige confrontaties hebben geleid en dat daarom tussen de betrokken etnische groepen achterdocht, wantrouwen en haat (zogeheten ancient hatreds) de betrekkingen zouden domineren. In zijn algemeenheid is deze visie niet overtuigend. De wereldsamenleving is in de huidige tijd verdeeld in zo'n tweehonderd staten en telt naar schatting omstreeks 5.000 à 6.000 onderscheiden etnisch-culturele groepen. Dat impliceert dat alle afzonderlijke staatssamenlevingen in meerdere of mindere mate multi-etnisch en polycultureel zijn. In alle samenlevingen bestaan ook spanningen van etnisch-culturele aard, maar de overgrote meerderheid kent geen of weinig etnisch geweld. De primordialistische visie is dus te algemeen en schiet tekort waar het nadere specificatie van belangrijke condities voor het ontstaan van etnisch geweld betreft. Daarbij gaat het bijvoorbeeld om de kwestie hoe en waarom etniciteit gepolitiseerd kan raken en om de vraag onder welke voorwaarden etnisch-culturele spanningen en tegenstellingen zich kunnen ontwikkelen tot gewelddadige confrontaties.

Maar het primordialisme biedt ook enkele inzichten van blijvende waarde die in alle kritiek erop soms verloren dreigen te gaan. Allereerst is dat het besef dat etnische diversiteit weliswaar geen oorzaak van etnisch geweld is, maar wel een noodzakelijke voorwaarde. En voorts het inzicht dat alle mensen in zekere mate primordiale bindingen en daarop gebaseerde individuele en collectieve identificaties kennen, dat deze door zeer velen in de meeste samenlevingen in hoge mate als vanzelfsprekend, zo niet als 'natuurlijk', worden ervaren, dat ze zichzelf en elkaar vaak mede in die termen classificeren, beoordelen en behandelen, en dat etnisch-culturele verschillen en scheidslijnen daarmee en daardoor een zeer realistisch en dwingend karakter kunnen hebben in de alledaagse werkelijkheid. Collectieve fantasieën over en weer, zowel vriendelijke als vijandige, en wat vaak aangeduid wordt als collectieve 
stereotypen en vooroordelen, maken daar ook integraal deel van uit. Ze worden door primaire socialisatie veelal van generatie op generatie overgedragen en bewaard in de collectieve herinnering van etnisch-culturele groepen. Nogmaals: dit alles leidt niet onvermijdelijk tot etnisch geweld - meestal niet -, maar deze facetten dienen in specifieke gevallen wel in het onderzoek betrokken te worden, ze kunnen de voedingsbodem vormen waarop in bepaalde tijden en onder bepaalde condities een ontwikkeling naar etnisch geweld kan plaatsvinden. Zonder een dergelijke voedingsbodem is etnisch geweld niet goed denkbaar.

Instrumentalisten hebben, deels in terechte kritiek op het primordialisme, benadrukt dat het bij etnisch geweld eigenlijk nooit gaat om plotselinge massale gewelddadige confrontaties tussen ongedifferentieerde woedende menigten. Die beeldvorming, die ook in de fragmentarische berichtgeving over etnisch geweld in de media doorgaans domineert en daarmee de onbegrijpelijkheid van het gepleegde geweld benadrukt, is grotendeels onjuist. Massaal geweld is nooit spontaan, maar op zijn minst gedeeltelijk georganiseerd. Potentiële geweldplegers dienen systematisch gerekruteerd, geïnformeerd, op enigerlei wijze bewapend, gemobiliseerd en ingezet te worden. In de instrumentalistische visie gaat dat hele proces van voorbereiding en organisatie uit van belanghebbende politieke elites, individuele politici en andere leiders op verschillende niveaus van de betrokken staatssamenleving. Etnisch geweld vloeit niet automatisch voort uit bestaande etnisch-culturele verschillen, maar wordt doelbewust teweeggebracht door (leden van) elites die menen daarmee eigen machtsbelangen te kunnen bevorderen.

De sterke kanten van deze visie zijn dat massale geweldpleging gedemystificeerd wordt, dat onderkend wordt dat het om georganiseerd geweld gaat en dat het onderzoek gericht wordt op het aandeel van leden van elites in het instigeren, organiseren en ontketenen van etnisch geweld. Een zwakkere kant is dat het risico bestaat dat de manipulatieve macht van elites en leiders overschat wordt, een instrumentalistische kijk kan dan verworden tot een complottheorie. Tegenwicht kan geboden worden door het besef dat degenen die geweld op gang brengen daarna lang niet altijd bij machte zijn om alle consequenties daarvan te voorzien, laat staan die te sturen en te beheersen. Massale geweldpleging heeft altijd ook onbedoelde gevolgen en de dynamiek van gewelddadige confrontaties heeft een eigen relatieve autonomie die gewoonlijk door geen van de betrokken partijen volledig beheerst kan worden.

Een andere zwakke kant is dat de volgelingen van de leiders soms te veel beschouwd worden als automatisch verlengstuk van die leiders en hun belangen en wensen. De benadering van etnisch geweld 'van bovenaf' is waardevol, maar de vraag blijft hoe initiatieven van bovenaf en initiatieven 'van onderop' in elkaar kunnen grijpen, waarom de volge- 
lingen volgen. Eigenlijk zijn hier slechts drie antwoorden mogelijk: dat komt door belang, consensus en dwang. Volgelingen kunnen parallelle maar niet noodzakelijkerwijze dezelfde belangen hebben als politieke leiders. Waar de laatsten via etnisch geweld meeromvattende politieke en economische belangen willen nastreven of veiligstellen, kunnen de eersten bijvoorbeeld uit zijn op straffeloos plunderen, verkrachten en moorden. Ideologische consensus tussen leiders en volgelingen, hoe fragmentarisch ook, speelt meestal evenzeer een grote rol. Juist inzichten uit het primordialisme kunnen hier verhelderend werken.

Wanneer etnische spanningen toenemen, zullen politieke leiders zich meer en meer gaan bedienen van etnisch-populistische retoriek. Zij zullen naar willekeur een beroep doen op veronderstelde primordiale loyaliteiten en identificaties, collectieve haatfantasieën over 'de anderen' aanwakkeren en putten uit het repertoire van collectieve herinneringen, hoe mythisch vaak ook. En dat werkt meestal - want de vereiste voedingsbodem is bij vele betrokkenen al aanwezig. Dit is een van de voornaamste mechanismen van de politisering van etniciteit en van wat in de inleiding de 'totalisering' van etniciteit is genoemd. Bij oplopende spanningen tussen etnische groepen in een algemeen onzekere en bedreigende situatie kan door ideologische retoriek een reductie van de complexiteit van de alledaagse werkelijkheid plaatsvinden waarbij deze schijnbaar teruggebracht wordt tot zijn vermeende 'etnische essentie'. Dat kan bij velen tijdelijk een collectieve bewustzijnsvernauwing teweegbrengen: het enige wat er dan nog toe lijkt te doen, is de gepercipieerde tegenstelling tussen de eigen etniciteit en die van de anderen. De eerste dient met geweld beveiligd en bevestigd te worden, de laatste met geweld vernietigd. Ten slotte kan ook dwang volgelingen tot volgen brengen. Wie in een situatie van zich ontwikkelend massaal etnisch geweld zijn neutraliteit tracht te bewaren kan onder zware druk komen te staan om toch op enigerlei wijze partij te kiezen. Vasthouden aan onpartijdigheid kan mensen dan zelfs het leven kosten.

Sociaal-constructivisten worden niet moe te verklaren dat etniciteit, collectieve etnische loyaliteiten en identificaties primair sociale of culturele constructies zijn. Met dit soms tot vervelens toe herhaalde standpunt hebben ze intellectueel wellicht gelijk, maar het brengt vaak met zich mee dat ze het sociologisch zeer realistische en dwingende karakter van allerlei aspecten van etniciteit in de alledaagse werkelijkheid van vele staatssamenlevingen onvoldoende onderkennen. Daarmee wordt ook te weinig recht gedaan aan de individuele en collectieve percepties en ervaringen van vele mensen in die samenlevingen. Een sterkere kant is dat benadrukt wordt dat etniciteit altijd relationeel, contextueel, situationeel en veranderlijk is. Het is niet waarschijnlijk dat politieke leiders met hun retoriek en symbolen etnische groepen als het ware 'in 
het leven kunnen roepen' zonder dat daar al een realistische voedingsbodem aan ten grondslag ligt. Hier dreigt opnieuw complotdenken en overschatting van de manipulatieve macht van politieke leiders.

Maar het onderzoek moet wel laten zien hoe en waarom de etnische dimensie van individuele en collectieve identificaties en van het maatschappelijke en politieke leven in specifieke gevallen en in bepaalde perioden zo prominent kan zijn of worden. Dan kan duidelijk worden dat het niet gaat om etniciteit of etnische diversiteit op zichzelf, maar om de betekenis die mensen daar onder bepaalde omstandigheden aan toekennen en de consequenties die dat heeft voor hun handelen. Zo lang een meerderheid van de mensen in een staatssamenleving van mening is dat etnische verschillen er niet zoveel toe doen, zal dat ook het geval zijn, maar wanneer aanzienlijke groepen gaan denken dat etnische verschillen problematisch en belangrijk zijn, zal dat meer en meer ook de realiteit worden. Wel kan worden gesteld dat in de samenleving van de laatste paar eeuwen, zowel het belang van de staat als van de etnisch-culturele categorie of 'natie' waar mensen toe behoren voor zeer grote groepen van de wereldbevolking spectaculair is toegenomen. Dat verklaart ook waarom etnisch geweld in de recente geschiedenis steeds meer op de voorgrond is getreden.

De vierde benadering - het (cultureel-)psychologische perspectief vestigt vooral de aandacht op collectieve psychologische en symbolische aspecten van etnisch geweld. Deze zijn ongetwijfeld van groot belang om bepaalde kanten van daadwerkelijke geweldpleging beter te kunnen interpreteren en om te kunnen begrijpen waarom mensen vaak met groot enthousiasme en geconcentreerde toewijding tot massaal geweld kunnen overgaan. Wel bestaat er binnen deze benadering een aanzienlijk risico op zeer veel omvattende psychologiserende generalisaties die sociologisch, politiek en economisch onvoldoende verankerd zijn. Zo is de these van het 'narcisme van de kleine verschillen' weliswaar intellectueel en literair aansprekend, maar ontbreekt het tot op heden in hoge mate aan voldoende historisch-empirische onderbouwing om werkelijk overtuigend te kunnen zijn. In het onderzoek naar politiek en etnisch geweld zijn psychologiserende generalisaties over de mentaliteit, de cultuur en de civilisering van de betrokken groepen mensen onmisbaar, maar die dienen dan zo goed mogelijk verbonden te worden met kennis en inzicht over de dynamiek van hun onderlinge relaties en hun politieke en economische machts- en afhankelijkheidsverhoudingen. De mentaliteit en de gedragsstandaarden van mensen zijn immers nauw vervlochten met hun onderlinge interdependenties en de wijze waarop hun samenleving gestructureerd is. Juist bij de studie van etnisch geweld is het van belang te beseffen dat de opvattingen en houdingen van mensen ten opzichte van geweldpleging en hun bereidheid en vermogen om 
geweld te plegen sterk kunnen variëren, afhankelijk van de samenleving waarin ze leven.

\section{Tot slot}

Het doel van deze beknopte synthetiserende nabeschouwing is geweest om in aansluiting op de afzonderlijke hoofdstukken een eerste aanzet te geven tot een geïntegreerd theoretisch perspectief voor de studie van massaal etnisch geweld. Vooral de wijzen waarop episoden van etnisch geweld ingebed zijn in langer lopende ontwikkelingen van staat en natie, economie en cultuur, zou verder belicht kunnen worden. In de huidige tijd lijkt etnisch geweld vooral voor te komen in relatief jonge staten met instabiele, fragiele of zwak gehandhaafde geweldsmonopolies en met een nog relatief geringe mate van verstatelijking en van democratisering van de samenleving. De natievorming bevindt zich veelal nog in een pril stadium en is soms diepgaand problematisch. Dat betekent niet alleen dat een zekere mate van burgerschap op nationaal niveau ontbreekt, maar vaak ook dat de primaire loyaliteit en identificatie van vele mensen uitgaat naar andere collectieve verbanden dan de natie als geheel. Dan kunnen onder omstandigheden van toenemende crisis bevolkingen betrekkelijk snel vérgaand verdeeld en gepolariseerd raken. Etnisch geweld lijkt ook meer voor te komen in samenlevingen die economisch nog verkeren in een voorindustriële, agrarische fase dan wel een moeizame overgang doormaken naar een meer industriële maatschappij. Zeer grote verschillen in bezit en inkomen tussen bevolkingsgroepen, aanzienlijke economische schaarste en grote armoede voor velen zijn typerend voor samenlevingen in een dergelijke fase van ontwikkeling. Ook dat kan bijdragen aan ernstige spanningen, tegenstellingen en conflicten tussen bevolkingsgroepen die etnisch-cultureel van elkaar verschillen.

Cultureel, ten slotte, gaat het vaak om samenlevingen waarin zeer velen nog in de ban zijn van collectieve en collectivistische tradities. Waar algemene ontwikkeling en goed onderwijs schaars zijn en vaak ontoegankelijk voor grote delen van de bevolking. En waar het met geweld veiligstellen van eigen belangen relatief meer gangbaar is, en soms ook bittere noodzaak. Ook dit alles kan verder verdisconteerd worden in een geïntegreerder theoretisch perspectief op etnisch geweld, maar dat zou het bestek van deze nabeschouwing te boven gaan. Dat laat overigens onverlet dat de historisch-empirische kennis en de theoretische reflectie die in deze bundel zijn samengebracht een gedegen en hopelijk inspirerend vertrekpunt vormen voor verder toekomstig onderzoek naar etnisch geweld. 


\section{Literatuur}

Hobsbawm, E. (1994). Age of Extremes. The Short Twentieth Century, 19141994. London: Michael Joseph.

Swaan, A. de (2003). Moord en de staat. Amsterdam: Bert Bakker.

Weber, M. (1988 [1921]). Politik als Beruf. In M. Weber, Gesammelte Politische Schriften (505-560). Tübingen: Mohr.

Wimmer, A., L.E. Cederman en B. Min (2009). Ethnic Politics and Armed Conflict: A Configurational Analysis of a New Global Data Set, American Sociological Review, Vol. 74, april, 316-337.

Zwaan, T. (2005). Politiek geweld. Etnisch conflict, oorlog en genocide in de twintigste eeuw. Zutphen: Walburg Pers. 



\section{Personalia}

Ward Berenschot studeerde politicologie aan de Universiteit van Amsterdam waar hij ook onderwijs heeft gegeven. Hij promoveerde in 2009 cum laude op Riot Politics. Communal Violence and State-Society Mediation in Gujarat, India. Hij verblijft op het ogenblik in Indonesië.

Jacob R. Boersema behaalde aan de Universiteit van Amsterdams Masters in Sociale Geografie en Geschiedenis. Hij is als aio verbonden aan Ontwikkelingsstudie aan dezelfde universiteit en schrijft een proefschrift over blanke, Afrikaanssprekenden in de periode na de apartheid in Zuid-Afrika.

Karen Büscher is Afrikaniste en als PhD-studente verbonden aan de Conflict Research Group van de Universiteit Gent, waar ze onderzoek doet naar processen van conflict en stedelijke transformatie in Goma, OostCongo.

Gerry van Klinken studeeerde natuurkunde en Azië-studies. Hij als onderzoeker verbonden aan het KITLV te Leiden. Hij schreef een boek over het ontstaan van grootschalig communaal geweld gedurende de democratische overgang in Indonesië na 1998.

Huibert Schijf studeerde politicologie en is verbonden aan de Afdeling Sociologie/Antropologie van de Universiteit van Amsterdam. Hij schrijft regelmatig over elites en hun netwerken en is redacteur van Mens $\&$ Maatschappij.

Uğur Ümit Üngör studeerde politicologie in Amsterdam en promoveerde in 2009 cum laude op Young Turks Social Engineering: Mass Violence and 
the Nation State in Eastern Turkey, 1913-1950. Hij is thans verbonden aan de University of Sheffield, Department of History, Centre for the Study of Genocide and Mass Violence.

164

Koen Vlassenroot is docent politieke wetenschappen en coördinator van de Conflict Research Group van de Universiteit Gent. Hij onderzoekt de dynamiek van conflicten in Centraal-Afrika en publiceert regelmatig in internationale tijdschriften over milities, landtoegang en het vredesproces in Oost-Congo.

Ton Zwaan studeerde sociale wetenschappen en is verbonden aan de Afdeling Sociologie/Antropologie van de Universiteit van Amsterdam en aan het Centrum voor Holocaust- en Genocidestudies van het NIOD en de KNAW. 
Media spreken bij etnisch geweld vaak van 'spontane uitbarstingen' van 'woedende menigten'. Maar etnisch geweld is zelden een spontane uitbarsting van spanningen tussen verschillende bevolkingsgroepen. De menigte is vaak gemobiliseerd door elites die het geweld exploiteren voor eigen gewin. Laten deelnemers aan geweld zich echt misleiden door complotsmedende leiders of zijn er andere verklaringen mogelijk?

Etnisch geweld: groepsconflicten in de schaduw van de staat combineert theoretische beschouwingen met onderzoek naar etnisch geweld. De auteurs concluderen dat de organisatie van etnisch geweld voortkomt uit de 'schaduw van de staat': schimmige netwerken van politici en anderen die gewone mensen helpen toegang te verkrijgen tot de overheid.

Ward Berenschot studeerde politicologie en promoveerde in 2009 op Riot Politics. Communal Violence and State-Society Mediation in Gujarat, in India. Huibert Schijf is verbonden aan de afdeling Sociologie/Antropologie van de Universiteit van Amsterdam en is redacteur van Mens Q Maatschappij.

Etnisch geweld: groepsconflict in de schaduw van de staat is de boekaflevering bij jaargang 84 (2009) van het sociaalwetenschappelijke tijdschrift Mens \& Maatschappij. 